$$
\begin{array}{r}
\text { Pontifícia Universidade Católica } \\
\text { do Rio de Janeiro }
\end{array}
$$

Jussara Oliveira do Nascimento

\title{
O Tratamento Mecânico e Biológico na Gestão de Resíduos no Município do Rio de Janeiro.
}

Dissertação de Mestrado

Dissertação apresentada como requisito parcial para obtenção do título de Mestre em Engenharia Urbana e Ambiental (opção profissional) pelo Programa de Pós-Graduação em Engenharia Urbana e Ambiental da PUC-Rio.

Orientadora: Prof. Ana Cristina G. Malheiros Pereira. Co-orientadora: Prof. Maria José Lopes de Araújo Saroldi.

Rio de Janeiro

Dezembro de 2014 


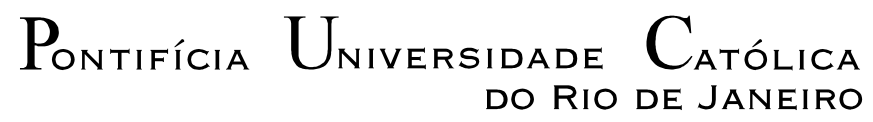

DO RIO DE JANEIRO

\section{Jussara Oliveira do Nascimento}

\section{O Tratamento Mecânico e Biológico na Gestão de Resíduos no Município do Rio de Janeiro}

Dissertação apresentada como requisito parcial para obtenção do título de Mestre em Engenharia Urbana e Ambiental (opção profissional) pelo Programa de Pós-Graduação em Engenharia Urbana e Ambiental da PUC-Rio. Aprovada pela Comissão Examinadora abaixo assinada.

\section{Prof. Ana Cristina Malheiros Gonçalves Carvalho \\ Presidente / Orientador \\ Departamento de Engenharia Civil - PUC-Rio}

Prof. Maria José Lopes de Araújo Saroldi

Co-Orientador - UERJ

Prof. Tácio Mauro Pereira de Campos Departamento de Engenharia Civil - PUC-Rio

Prof. Celso Romanel

Departamento de Engenharia Civil - PUC-Rio

Prof. José Eugenio Leal Coordenador Setorial de Pós-Graduação do Centro Técnico Científico - PUC-Rio

Rio de Janeiro, 19 de dezembro de 2014. 
Todos os direitos reservados. É proibida a reprodução total ou parcial do trabalho sem autorização da universidade, da autora e do orientador.

\section{Jussara Oliveira do Nascimento}

Graduou-se em Engenharia de Produção na UFF (Universidade Federal Fluminense) em 2002, fez Pós-Graduação em Marketing pela FGV-RJ (Fundação Getúlio Vargas). Trabalhou por 12 anos na Ipiranga Produtos de Petróleo S.A, nas áreas de Marketing, Desenvolvimento de Produtos e Planejamento. Atualmente estuda a Gestão de Resíduos, especificamente o Tratamento Mecânico e Biológico.

Ficha Catalográfica

Nascimento, Jussara Oliveira do

O tratamento mecânico e biológico na gestão de resíduos no município do Rio de Janeiro. Jussara Oliveira do Nascimento; orientadora: Ana Cristina G. Malheiros Pereira; coorientadora: Maria José Lopes de Araújo Saroldi. - 2015.

179 f. : il. (color.) ; $30 \mathrm{~cm}$

Dissertação (mestrado)-Pontifícia Universidade Católica do Rio de Janeiro, Departamento de Engenharia Civil, Programa de Pós-Graduação em Engenharia Urbana e Ambiental, 2015.

Inclui bibliografia

1. Engenharia civil - Teses. 2. TMB. 3. Tratamento mecânico e biológico. 4. Resíduo. 5. Lixo. 6. Gestão de resíduos domiciliares. 7. Reciclagem. 8. Separação do lixo. 9. Reaproveitamento do lixo. 10. Resíduo sólido urbano. 11. RSU. I. Pereira, Ana Cristina G. Malheiros. II. Saroldi, Maria José Lopes de Araújo. III. Pontifícia Universidade Católica do Rio de Janeiro. Departamento de Engenharia Civil. IV. Título. 
À minha mãe, Dalva Oliveira do Nascimento, mulher exemplar, mãe, esposa, filha, nora, avó, profissional e cidadã. Mãe de 8 filhos, iniciou o exercício da maternidade com seus irmãos, que ajudou minha avó a criar.

Além dos irmãos e filhos, ainda cuidou dos pais, dos sogros e de muitos outras pessoas que buscavam nela seu alicerce para seguir a vida.

Meu principal exemplo de amor incondicional, me ensinou a amar e dar valor às coisas mais importantes da vida: a família, a natureza e ao próximo. Ensinou a seguir a vida com simplicidade e sabedoria.

Desde pequenos, minha mãe exigia muito dos filhos e nos mostrava o quanto o estudo era importante para o crescimento profissional, o quanto a leitura e a análise crítica fariam de nós pessoas mais cultas e sábias. E ela estava certa! 
Ao meu pai, Jurandyr do Nascimento, exemplo de dedicação profissional sem deixar a paternidade de lado, homem de muita honestidade, força e caridade. Ótimo filho, também cuidou dos pais e sogros, com dedicação exemplar.

Juntos, meu pai e minha mãe construíram uma linda família, em meio a muitas dificuldades financeiras, prevalencendo sempre os valores mais importantes.

E muito antes de todas as questões ambientais virem à tona, já vivíamos em família aprendendo a poupar recursos, a reutilizar e reciclar. Não só por necessidades financeiras, como também pela forma que pensavam sobre o aproveitamento das coisas.

Aos meus irmãos, Jacira, Josina, Davi, Janete, Josete e Dilson, que iniciaram sua vida profissional mais cedo que eu. Pude dedicar mais tempo aos estudos graça a eles. Contribuíram para a formação do meu caráter, me deram a alegria da brincadeira quando crianças e a convivência com os muitos e lindos sobrinhos!

Além dos sobrinhos, mais pessoas compuseram nossa grande e linda família: os cunhados e cunhadas, mais irmãos, mais alegria!

Agradeço especialmente à Josina e Janete, minhas segundas mầ exemplos de amor incondicional, a quem devo muıv.

Ao meu querido e amado marido, Daniel Valente Serman, meu porto seguro, pelo amor, apoio e companheirismo de todos os dias, pelo carinho e dedicação a mim e às crianças.

Homem exemplar, profissional, neto, filho, irmão e pai. Como se não bastasse isso tudo, ainda me deu uma nova família, tão maravilhosa como a minha, novos pais, avós e irmãos mais novos.

Dedico ainda ao Pedro Nascimento Serman e Isabel Nascimento Serman, filhos fofos, fontes de amor incondicional, alegria interminável e felicidade infinita, que possuem a incrível capacidade de deixar qualquer tristeza ou dificuldade de lado com um único abraço!

Por último e não menos importante, à Juaciara dos Santos de Lima, pessoa a quem deposito a minha confiança diária para deixar meus filhos e ir ao trabalho com toda a tranquilidade do mundo. Possui não só o dom nato de educar, como também um espírito maravilhoso, mais um exemplo de mulher, profissional, cidadã, mãe e avó em minha vida.

Todos fazem parte de cada frase, de cada palavra deste trabalho. 


\section{Agradecimentos}

Às orientadoras, Ana Cristina e Maria José, que despenderam seu precioso tempo comigo, que aturaram mudanças de tema, dúvidas profissionais e complementos nos últimos minutos.

À Paula Enoy, sempre disponível e paciente com todos os alunos, ajudando no possível e impossível.

Aos professores do curso, em especial aos professores Celso Rommanel e Tácio Campos, que ouviram minhas dúvidas para estudos em resíduos, que me ajudaram a buscar a banca para a avaliação da tese, dentre outras ajudas.

Aos colegas de turma, Jorge Lucas, Daniel Velez, Jayme e Angélica Vidigal pela ajuda com a Isabel ainda bebê, pela interação e interesse em aprender e em trocar conhecimento nos trabalhos de grupo.

A todos os funcionários da Comlurb, que estiveram disponíveis para contatos telefônicos, email e visitas.

À professora Valeria Bastos, pela disponibilidade, ensinamentos e cordialidade de sempre. 


\section{Resumo}

Nascimento, Jussara Oliveira do; Pereira; Ana Cristina G. Malheiros; Saroldi, Maria José Lopes de Araújo. O Tratamento Mecânico e Biológico na Gestão de Resíduos no Município do Rio de Janeiro. Rio de Janeiro, 2014. 179p. Dissertação de Mestrado - Departamento de Engenharia Civil. Pontifícia Universidade Católica do Rio de Janeiro.

O aumento da produção mundial de resíduos e a falta de programas de gestão adequados a estes resultam no descarte e disposição inadequadas, causando inúmeros impactos ambientais e afetando, inclusive, à saúde humana. Tais resíduos, por apresentarem alto poder calorífico, versatilidade e resistência, devem ser tratados como matéria prima pósconsumo e não como lixo, podendo ser utilizados de inúmeras formas. Uma delas é a reciclagem, um processo que apresenta nova utilização aos resíduos antes designados como lixo, gerando possibilidades de rentabilidade e emprego. A reciclagem tem grande importância na gestão social de um município, pois está ligada diretamente às classes de baixa renda. Tais processos têm crescido no Brasil, principalmente após a publicação da Política Nacional de Resíduos Sólidos (PNRS) - Lei $n^{\circ}$ 12.305, que exige um plano de resíduos para cada município, incentivando a reciclagem e compostagem de lixo. Ainda assim, o problema persiste, devido à falta de programas de coleta seletiva, falta de incentivo aos recicladores e catadores, bem como descaso dos governos e da população. A probabilidade de melhoria é grande, porém demandará muito tempo e investimento. O tratamento mecânico e biológico é apresentado então como uma solução para o cumprimento dos objetivos no tratamento de resíduos em curto prazo. Este trabalho tem o objetivo de analisar tal tecnologia e sua aplicação no município do Rio de Janeiro, avaliando suas vantagens, desvantagens e restrições para este processo.

\section{Palavras-chave}

TMB; tratamento mecânico e biológico; resíduo; lixo; gestão de resíduos domiciliares; reciclagem; separação do lixo; reaproveitamento do lixo; resíduo sólido urbano; RSU. 


\section{Extended Abstract}

Nascimento, Jussara Oliveira do; Ana Cristina G. Malheiros (Advisor); Saroldi, Maria José Lopes de Araújo (Co Advisor). The Mechanical Biological Treatment Waste in the city of Rio de Janeiro. Rio de Janeiro, 2014. 179p. Msc. Dissertation - Departamento de Engenharia Civil. Pontifícia Universidade Católica do Rio de Janeiro.

The progress of humanity and the encouragement of increased consumerism have generated the supply and mass consumption products. A greater extent, so does the production of waste in the world, together with the scarcity of non-renewable resources in the long term, climate change, have diverted attention to environmentally sustainable practices involving waste management.

In this context, the Management of Municipal Solid Waste (MSW), translates into a complex process that requires multidisciplinary views, working from the logistics in the process of collection, storage and disposal of waste to the Biology, Chemistry and Thermodynamics, given the diversity of techniques and technologies available for your treatment and recovery in the market.

Social development is also an important point, since in countries like Brazil recycling is an activity that generates resources for social classes with lower purchasing power. In addition to operating in the production of consumer goods from waste, much of the recyclable materials back to the market due to the work of sorters, people with very low income, who are in this profession a form of survival.

These factors are relevant to the implementation of any management system, which requires significant investment and participation of the public authorities, both legislative and executive.

Developed countries, such as members of the European Union (EU), are far ahead in MSW Management, seeking ways of dealing with their waste less and less impactful to the environment.

Brazil still is a more technical phase and less practical than the EU, but has important advances. In 2010, entered into force on National Solid Waste Policy (NSWP), established by Law 12.305.

This Policy establishes strategies and deadlines for the Brazilian sustainable development, reviews the hierarchy of priorities in waste treatment and imposes the reverse logistics system, and treat life-cycle of products and encourage the reuse, recycling of materials and composting waste, eliminating the dumps and leaving foster landfilling, lagging only this waste without a more favorable allocation to the environment and saving resources. 
Waste management before the publication of NSWP was a subject increasingly discussed by public managers, became part of plans goals of states and municipalities, gaining more importance in government planning processes, impacting factor for the development of actions to encourage environment-related practices.

Even with the National Solid Waste Policy in force, compliance with established goals will require a long time because it involves a drastic change of culture and needs of the population mainly of direct support of the government, generating greater involvement of technical manpower, allocation of significant grant, need for partnership between municipalities and continuity in projects, critical points of the Brazilian Public Management.

In order to comply with environmental goals in the shortest time, the aim of this work is to present and analyze the Mechanical Treatment and Biological waste (MBT) as an option for improving the municipal solid waste management in the city of Rio de Janeiro in a sustainable way, while meeting the NSWP.

To this end, we intend to analyze the current situation with regard to the Municipal Solid Waste Management in national, state level and in the city of Rio de Janeiro, presenting case studies of sites started using a MBT in Brazil, as well as international examples, thus seeking to evaluate advantages and disadvantages of this process, raising critical to the application of this technology.

Given the scarcity of national experience in this subject, the methodology used for the study was based on extensive literature review, using books, scientific articles and internet.

To define the scenario of the city of Rio de Janeiro and analysis of case studies were also conducted expert interviews and field research in Screening and Plants in operation.

The mechanical and biological treatment (MBT) is a process used successfully in EU member countries, presenting itself as a complex, flexible and several variations for the treatment of mixed waste or simply MSW (municipal solid waste), aiming to best possible use, reducing the residual portion to the final destination.

The concept originated in Germany and Austria involved all mechanical and biological systems used for the reduction of waste, which could be used separately. Over time, the term has evolved to achieve integrated systems that used the mechanical and biological treatment within the same process.

According to Juniper (2005), the process is divided into two phases: the mechanics, which involves separation means which remove some waste fractions mechanically, such as separation by size or weight, and 
recovering materials for recycling organic involving means for stabilizing the organic fraction for characteristics become reasonable for other uses.

Juniper (2005), through a study covering 80 plants in the EU, responsible for processing waste 8 million / year, also lists the main advantages in the use of technology, such as better use of dry waste for recycling, the reduction the volume of waste to final destination and moisture and volume of the organic fraction, the use of the organic fraction into compost or energy and reducing gas forming potential (greenhouse gas and odors at the landfill).

However, Stephanie (2011) presents technical, economic and environmental challenges evaluated in 61 plants in Germany, which add up to a total capacity of 6.4 million tons / year: high level of equipment wear, number of stops in production and contamination in the ballistic separator, representing the difference between the actual and planned with respect to time for maintenance and cleaning, number of people and energy expenditure, and a high variation of biogas production due to the discontinuous input substrate.

Also according to Stephanie (2011), the cost of using this technology is similar to the incineration spent in the EU: 100 Euro per tonne. The cost factor is presented as the main downside of the technology, which needs to be evaluated in detail for each type of MBT plant installed, comparing the investment involved with revenues from the sale of recyclables, compost, biogas and RDF (Refuse Derived Fuel), also used for generating electricity.

The NSWP establishes a new hierarchy for the recovery of waste, starting with the non-generation, reduction, re-use, recycling and treatment, leaving the final destination as the last stage.

In addition, both the NSWP as the National Plan for Solid Waste (still in approval) set goals to meet in the short term, as the closing landfills by 2014 , the reduction of organic and dry waste to landfills, development of selective collection and need the development of regional plans of solid waste as a condition for access to the resources of the Union, or controlled by it.

Both Brazil, state and the city of Rio de Janeiro, region focus of this study, are still far behind with regard to meet those goals.

According to ABRELPE (2013), Brazil has $41 \%$ of its waste for landfills or controlled landfills, $58 \%$ landfill and a small portion to other types of treatment, then prioritizing the disposal compared to the other forms as the NSWP. For selective collection, only $3 \%$ of the collected dry waste is recovered from long process, compared to a target of $5 \%$, effective for 2013. 
For the city of Rio de Janeiro, the study presents, using the methodology of LINDON et. al (2004) to present the SWOT analysis, results as follows.

\begin{tabular}{|l|}
\hline \multicolumn{1}{|c|}{ STREGHTS } \\
\hline Coverage of waste collection in all \\
locations. \\
Ellliminations of dumps. \\
Biogas from landfills. \\
Published PMGIRSU/RJ and in progress.. \\
Composed of marketing existence, \\
although under. \\
RDF of marketing existence, although \\
under. \\
Visibility of the city compared to the \\
other in Brazil. \\
OPPORTUNITIES \\
Orowing biogas and RDF market. \\
Investment opportunities for new \\
technologies. \\
Increasing recycling market. \\
New garbage sorting technologies with \\
short-term return. \\
\hline
\end{tabular}

\begin{tabular}{|l|}
\hline \multicolumn{1}{|c|}{ WEAKNESS } \\
\hline Recycling dependent on selective \\
collection. \\
Low coverage of selective collection. \\
High logistic costs and investments \\
involved for selective collection. \\
Low level of knowledge of collectors. \\
Low level of responsability of collectors. \\
High volume of waste sent to landfills. \\
Environmental impacts and \\
representative costs involved to the large \\
volume of waste sent to landfills. \\
Not meet the waste disposal hierarchy as \\
NSWP. \\
\hline \multicolumn{1}{c}{ THREATS } \\
High costs for the marketing of recycled \\
materials. \\
the implementation of \\
new level of involvement of the \\
Lack of interaction between municipal \\
managers. \\
Lack of systemic view to the municipal \\
managers.
\end{tabular}

Thus, the MBT is presented as an important solution for the city of Rio de Janeiro, with short-term results to mainly address the weaknesses in Case of selective collection and the disposal of organic waste.

To analyze the application of this technology, the dissertation presents an evaluation, comparing the current situation $(90 \%$ of waste sent to landfill and $10 \%$ treated) with a proposed scenario $(50 \%$ of the waste with the same treatment of the current scenario and $50 \%$ intended for UMBT), based on 15 critical success factors, resulting in the following table.

The criteria for evaluation of each critical factor are defined as your fitness level environmental policies or according to the time required for the achievement of goals: Concept 1 - entirely appropriate environmental policies or service short-term goals; Concept 2 - partially suitable 
environmental policies or call the targets in the medium term; Concept 3 low compliance to environmental policies or service long-term goals.

To obtain the final concept, the higher the total score will be the least appropriate scenario evaluated, according to the critical factors and hence the required environmental policies, as the following chart.

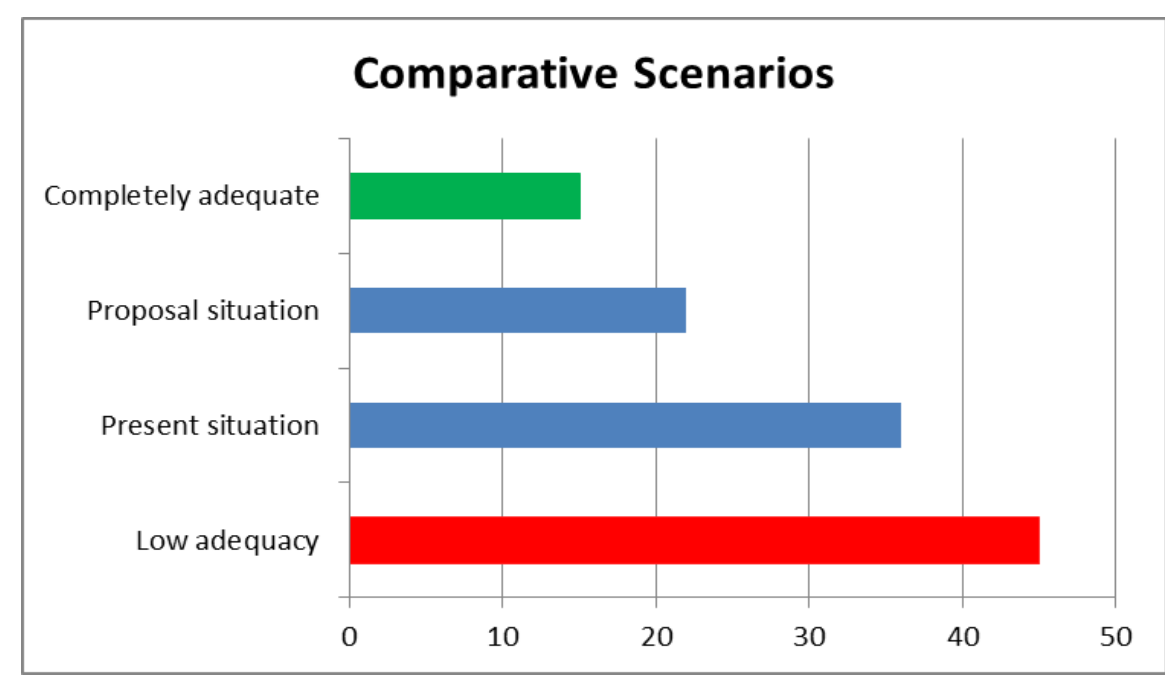

\begin{tabular}{|c|c|c|c|}
\hline \multirow[b]{2}{*}{$\begin{array}{l}\text { CRITICAL } \\
\text { FACTORS }\end{array}$} & $\begin{array}{l}\text { PRESENT } \\
\text { SITUATION }\end{array}$ & $\begin{array}{l}\text { PROPOSAL } \\
\text { SITUATION }\end{array}$ & \multirow[b]{2}{*}{ COMENTARIES } \\
\hline & $\begin{array}{l}\text { Landfill + } \\
\text { selective } \\
\text { collection }\end{array}$ & $\begin{array}{c}\text { MBT, } \\
\text { Composting } \\
\text {, FDR, AD }\end{array}$ & \\
\hline Logistics costs & 3 & 1 & $\begin{array}{l}\text { Number of vehicles } 50 \% \text { higher, at least } \\
\text { to serve the same route in the selective } \\
\text { collection and MSW; Need for } \\
\text { screening units for shipment to final } \\
\text { destination; More vehicles for sending } \\
\text { waste to landfill. }\end{array}$ \\
\hline $\begin{array}{c}\text { Greenhouse Gas } \\
\text { Emission }\end{array}$ & 3 & 1 & $\begin{array}{l}\text { The increased flow of vehicles } \\
\text { generates more greenhouse gases. }\end{array}$ \\
\hline $\begin{array}{l}\text { Technological } \\
\text { investment }\end{array}$ & 1 & 3 & $\begin{array}{l}\text { High investment in equipment for the } \\
\text { MBT plant }\end{array}$ \\
\hline $\begin{array}{l}\text { Awareness on } \\
\text { Investment }\end{array}$ & 3 & 1 & $\begin{array}{l}\text { Continuous investment need for } \\
\text { separating waste from the population }\end{array}$ \\
\hline $\begin{array}{l}\text { Volume sent to } \\
\text { landfill }\end{array}$ & 3 & 1 & $\begin{array}{l}\text { Increased waste sent to landfill, as only } \\
\text { the Caju Plant has units for waste } \\
\text { processing. }\end{array}$ \\
\hline $\begin{array}{l}\text { Cost of } \\
\text { remediation of } \\
\text { landfill post } \\
\text { closure }\end{array}$ & 2 & 1 & $\begin{array}{l}\text { With larger volumes sent to landfill, the } \\
\text { treatment time after its completion will } \\
\text { be higher. }\end{array}$ \\
\hline
\end{tabular}




\begin{tabular}{|c|c|c|c|}
\hline $\begin{array}{l}\text { Cost of manure } \\
\text { treatment }\end{array}$ & 3 & 1 & $\begin{array}{c}\text { By reducing the volume sent to the } \\
\text { landfill, leachate production falls } \\
\text { proportionally reducing its cost of } \\
\text { treatment. }\end{array}$ \\
\hline $\begin{array}{l}\text { Duration of the } \\
\text { landfill }\end{array}$ & 1 & 3 & $\begin{array}{l}\text { With larger volumes sent to landfill, the } \\
\text { length of time this will be higher. } \\
\text { According to the quantities simulated } \\
\text { this methodology, the length of time } \\
\text { present } 50 \% \text { increase. }\end{array}$ \\
\hline $\begin{array}{l}\text { Biogas } \\
\text { generation }\end{array}$ & 2 & 1 & $\begin{array}{c}\text { Both the landfill as anaerobic digestion } \\
\text { included in BMR plant can generate } \\
\text { biogas, MBT plant being in smaller } \\
\text { proportions. }\end{array}$ \\
\hline $\begin{array}{c}\text { Knowledge level } \\
\text { required for } \\
\text { operation }\end{array}$ & 2 & 3 & $\begin{array}{l}\text { The MBT equipment requires more } \\
\text { technical knowledge. }\end{array}$ \\
\hline $\begin{array}{c}\text { Political } \\
\text { involvement } \\
\text { level }\end{array}$ & 3 & 1 & $\begin{array}{c}\text { Somente no início para o investimento } \\
\text { em equipamentos. }\end{array}$ \\
\hline $\begin{array}{l}\text { Compliance with } \\
\text { the recycling } \\
\text { rate }\end{array}$ & 3 & 1 & $\begin{array}{l}\text { The mechanical treatment unit can } \\
\text { increase the volume of recyclable items } \\
\text { in the short term. A material in the } \\
\text { washing unit MBT plant can generate } \\
\text { more items recovered for recycling. }\end{array}$ \\
\hline $\begin{array}{c}\text { Hierarchy of } \\
\text { compliance for } \\
\text { waste treatment }\end{array}$ & 3 & 1 & $\begin{array}{l}\text { The MBT plant will forward the waste } \\
\text { according to the hierarchy defined in } \\
\text { Waste Brazilian Law. }\end{array}$ \\
\hline $\begin{array}{l}\text { Meeting this } \\
\text { goal for } \\
\text { involvement } \\
\text { collectors }\end{array}$ & 1 & 2 & $\begin{array}{c}\text { With lower level of mechanization, the } \\
\text { separation of recyclable items } \\
\text { originated selective collection requires } \\
\text { the participation of a larger number of } \\
\text { collectors. }\end{array}$ \\
\hline $\begin{array}{l}\text { return to } \\
\text { profitability of } \\
\text { collectors }\end{array}$ & 3 & 1 & $\begin{array}{c}\text { The larger volume of recyclables to } \\
\text { market generates higher revenues. TM } \\
\text { has greater productivity in obtaining } \\
\text { recyclable materials. }\end{array}$ \\
\hline TOTAL & 36 & 22 & \\
\hline
\end{tabular}

Thus, it is concluded that the use of a UMBT for the city will bring shortterm results and meet the objectives of NSWP. To better understand the cost and consequent economic viability, it is necessary a more detailed analysis of costs and revenues in the process.

\section{Key words}

MBT; Mechanical and Biological Treatment; waste; waste management; recycling; waste to energy; waste to resource; urban waste. 


\section{Sumário}

1. Introdução 23

2. Gestão de Resíduos Sólidos Urbanos 26

2.1. Classificação dos resíduos 26

2.1.1. Classificação dos resíduos quanto à origem 26

2.1.2. Classificação dos resíduos quanto aos riscos 27 potenciais ao meio ambiente

2.1.3. Classificação dos resíduos quanto ao grau de 28 degradabilidade

2.2. Propriedades Físicas, Químicas e Biológicas dos 29 resíduos.

2.2.1. Composição gravimétrica 29

2.2.2. Distribuição granulométrica 30

2.2.3. Teor de umidade 32

2.2.4. Temperatura 33

2.2.5. Peso Específico 34

2.2.6. Permeabilidade 35

2.2.7. Poder Calorífico 37

2.2.8. Classificação Química 39

2.2.9. Classificação Biológica 39

2.3. Métodos de destinação final dos RSU 40

2.3.1. Digestão Anaeróbica 42

2.3.2. Compostagem 43

2.3.3. Incineração 45

2.3.4. Lixões ou vazadouros $\quad 47$

2.3.5. Aterros Controlados 48

2.3.6 Aterros Sanitários $\quad 48$

2.3.7 Reciclagem de resíduos secos $\quad 52$

2.4. Coleta Seletiva 62

2.5. Legislação Brasileira 65

2.6. O Tratamento Mecânico e Biológico (TMB) 69

2.6.1. Tratamento Mecânico - detalhamento 71

$\begin{array}{ll}\text { 2.6.2. Tratamento Biológico } & 77\end{array}$

3. Cenário Atual 78

3.1. Gestão de Resíduos no Brasil 78

3.1.1. Destinação final de RSU 81

3.1.2. Coleta de RSU

3.1.3. Coleta Seletiva 88

3.1.4. Catadores 94

3.1.5. Reciclagem 96

3.1.6. Metas Propostas para a GRSU no Brasil 101

3.2. A Gestão de Resíduos no Estado do Rio de Janeiro 105

3.3. A Gestão de Resíduos no município do Rio de 112 Janeiro

3.3.1. Objetivos e metas 119

3.3.2. Análise geral da Gestão de RSU no município do 121 Rio de Janeiro - Matriz FOFA/SWOT 
4. A utilização do TMB na Cidade do Rio de Janeiro 129

4.1. Estudo de caso - Portugal - Unidade Valnor 143

4.2. Estudo de caso - São Paulo - Central de Triagem 152 Carolina Maria de Jesus - Ecourbis

5. Considerações Finais 157

$\begin{array}{ll}\text { Referências Bibliográficas } & 159\end{array}$

APÊNDICE A - Relatório de Pesquisa de Campo - Unidade 164 de Triagem Irajá

APÊNDICE B - Relatório de Pesquisa de Campo - Unidade 166

do Caju

APÉNDICE C - Relatório de Pesquisa de Campo - Central

172

Mecanizada Ecourbis

APÉNDICE D - Entrevista - Centro de Gestão Comlurb

APÊNDICE E - Maqbrit - orçamento de equipamentos 


\section{Lista de Tabelas}

Tabela 1 - Coeficientes para permeabilidade para o RSU 37

Tabela 2 - Poder calorífico de materiais encontrados em RSU 38

Tabela 3 - Índices de reciclagem de PET e latas de alumínio 53

Tabela 4 - Composição gravimétrica de RSU Brasil 54

Tabela 5 - Comparativo de emissões de $\mathrm{CO}_{2} \quad 62$

Tabela 6 - Evolutivo de legislações ambientais 66

Tabela 7 - Destinação final de RSU - 2000 e 2008

Tabela 8 - Principais destinações de RSU por município 2008

Tabela 9 - Destino final de RSU no Brasil - 1989/2008 83

Tabela 10 - Municípios brasileiros por destinação adotada $\quad 84$

Tabela 11 - Valor contratual para disposição de resíduos em $\quad 85$ aterro.

Tabela 12 - Cobertura da coleta direta e indireta de RSU. 86

Tabela 13 - Índice per capita de Coleta de RSU - 2012, 2013.

Tabela 14 - Quantidade de RSU por região do Brasil. 87

Tabela 15 - Recursos Aplicados na Coleta de RSU. 88

Tabela 16 - Participação dos programas de coleta seletiva formal $\quad 90$

Tabela 17 - Distribuição da coleta seletiva por região. 91

Tabela 18 - Quantidade de material recuperado por 91

programadas de coleta seletiva.

Tabela 19 - Caracterização de sistemas de coleta seletiva. 92

Tabela 20 - Benefícios econômicos da reciclagem. 97

Tabela 21 - Reciclagem do plástico - 2005 a 2007.

Tabela 22 - Reciclagem do vidro - 2005 a 2008.

Tabela 23 - Índices per capita de RSU nas Regiões do Estado. 105

Tabela 24 - Composição gravimétrica do lixo por município do 106

RJ.

Tabela 25 - Quantidade de Resíduos recuperanos na coleta 107

seletiva no Estado do RJ (2013).

Tabela 26 - Metas do Estado do RJ para a Gestão de RSU - 110

Grupo 1.

Tabela 27 - Metas do Estado do RJ para a Gestão de RSU - 110

Grupo 2.

Tabela 28 - Origem dos resíduos do município encaminhados à 113

Comlurb.

Tabela 29 - Resíduos por área de planejamento do município. 114

Tabela 30 - Unidades de Triagem de RSU no município. 116

Tabela 31 - Unidades de Separação de resíduos da coleta 118

seletiva no município.

Tabela 32 - Metas definidas no PMGIRS do município. $\quad 120$

Tabela 33 - Matriz SWOT/FOFA.

Tabela 34 - Descrição de processos - Usina do Caju. 126

Tabela 35 - Fatores críticos para análise de cenários. 131

Tabela 36 - Análise comparativa de cenários na GRSU no 133

município do Rio de Janeiro.

Tabela 37 - Critérios para avaliação da análise comparativa. 133

Tabela 38 - Geração de energia: Unidade TMB e Aterro 137

Sanitário. 
Tabela 39 - Coleta seletiva: resultados do município do Rio de Janeiro em 2012 e projeção para próximos anos.

Tabela 40 - Resultados obtidos na separação de itens recicláveis no TMB.

Tabela 41 - Quantidade de catadores envolvidos - comparativo entre situação proposta $x$ Ecourbis.

Tabela 42 - Resumo de investimentos Valnor.

Tabela 43 - Resultados Valnor: coleta seletiva e TMB.

Tabela 44 - Comparativo de resultados e potencial Valnor.

Tabela 45 - Locais para destinação dos resíduos no município.

Tabela 46 - Destinação dos resíduos na Usina do Caju.

Tabela 47 - Descrição geral do processo - Usina do Caju.

168

Tabela 48 - Situação das centrais de triagem previstas para a

175 coleta seletiva do município do Rio de Janeiro. 


\section{Lista de Figuras}

Figura 1 - Classificação dos RSU segundo a sua origem 27

Figura 2 - Diâmetros equivalentes dos componentes de RSU 31

Figura 3 - Variação da temperatura do RSU com a profundidade 34

Figura 4 - Hierarquia da Gestão de Resíduos 40

Figura 5 - Hierarquia da Gestão de Resíduos conforme PNRS 41

Figura 6 - Tratamento Biológico por Compostagem 44

Figura 7 - Aterro de Gramacho - foto 48

Figura 8 - Desenho esquemático de um aterro sanitário 49

Figura 9 - Evolução da produção de biogás em aterro sanitário $\quad 51$

Figura 10 - Fluxo das etapas da reciclagem mecânica- plástico 56

Figura 11 - Fluxo das etapas da reciclagem química- plástico $\quad 57$

Figura 12 - Produção e destinação de plásticos 57

Figura 13 - Fluxo do processo de reciclagem de papel 59

Figura 14 - Processo de produção de CDR 61

Figura 15 - Descrição geral do processo TMB 71

Figura 16 - Descrição esquemática dos equipamentos de uma $\quad 73$

UTMB.

Figura 17 - Foto de um Trommel

Figura 18 - Esquema funcional de um separador balístico $\quad 75$

Figura 19 - Separador .balístico - figura esquemática 75

Figura 20 - Esquema de separação através de separação ótica $\quad 76$

Figura 21 - Emissões brasileiras de GEE $\quad 79$

Figura 22 - Geração brasileira de RSU - total e per capita $\quad 79$

Figura 23 - Geração per capita de RSU - Brasil e demais países $\quad 80$

Figura 24 - Gasto unitário no gerenciamento de resíduos $\quad 80$

Figura 25 - Empregos gerados no setor de limpeza urbana 81

Figura 26 - Evolução do gerenciamento dos RSU em países $\quad 81$

europeus.

Figura 27 - Destinação final dos RSU coletados no Brasil. 82

Figura 28 - Destinação final dos RSU coletados no Brasil 84

(ton/dia).

Figura 29 - Coleta de RSU total (ton/dia) e per capita.. 85

Figura 30 - Índice de abrangência da Coleta de RSU por região 87

Figura 31 - Composição gravimétrica de países de acordo com a $\quad 89$ renda.

Figura 32 - Consumo aparente de embalagens Brasil.

89

Figura 33 - Iniciativas de coleta seletiva nos municípios. $\quad 90$

Figura 34 - Iniciativas de coleta seletiva por grupos de $\quad 91$

municípios.

Figura 35 - Agentes executores da coleta seletiva municipal. $\quad 92$

Figura 36 - Evolução de custos da coleta seletiva. 93

Figura 37 - Visão geral da reciclagem brasileira. 96

Figura 38 - Faturamento das cooperativas e atacadistas. 98

Figura 39 - Índices de reciclagem por tipo de material. 98

Figura 40 -Índice de reciclagem - alumínio, plástico e papel - 99

2010 a 2012.

Figura 41 - Metas do Plano Nacional de Resíduos Sólidos. 103

Figura 42 - Estados com Política de Gestão de RSU 104 
regulamentada por lei.

Figura 43 - Evolução do Programa Lixão Zero. 108

Figura 44 - Relação entre indústrias de reciclagem no Estado. 109

Figura 45 - Cenário para arranjos regionais do Estado do RJ. 109

Figura 46 - Responsabilidades dos municípios no PERS/RJ. 111

Figura 47 - Divisão de regiões no município do Rio de Janeiro. 112

Figura 48 - Participação do RSU no município do Rio de Janeiro. 113

Figura 49 - Participação do RSU nas emissões de GEE. 114

Figura 50 - Composição do lixo domiciliar e de sua fração 115 reciclável.

Figura 51 - Geração de resíduos e destinação no município. $\quad 116$

Figura 52 - Proposta de fluxo logístico com o CTR-Rio. 117

Figura 53 - Fluxo logístico de resíduos na Usina do Caju. 124

Figura 54 - Comparativo de pontuações finais obtidas de acordo 131

com a metodologia de análise aplicada no estudo.

Figura 55 - Produção total de RSU por sistema - Portugal. 143

Figura 56 - Fluxo de tratamento de resíduos Valnor. $\quad 144$

Figura 57 - Evolução do Volume de Negócios Valnor. $\quad 145$

Figura 58 - Participação nas receitas do negócio Valnor. $\quad 145$

Figura 59 - Mapa de Infraestruturas da Valnor. 146

Figura 60 - Etapas do processo Valnor. $\quad 147$

Figura 61 - Fotos de etapas do processo Valnor. 147

Figura 62 - Fotos de coletores Valnor. 148

Figura 63 - Distribuição após tratamento mecânico Valnor. 149

Figura 64 - Material recuperado e potencial Valnor. 149

Figura 65 - Resultado da Coleta Seletiva da Valnor. $\quad 150$

Figura 66 - Valorização energética - DA e Aterro Valnor. $\quad 150$

Figura 67 - Mapa da Coleta de Lixo Domiciliar - Cidade de São 152

Paulo.

Figura 68 - Fluxo Esquemático na CMT. 154

Figura 69 - Fluxo operacional na Unidade de Triagem de Irajá. $\quad 165$

Figura 70 - Fluxo de Operação na Usina do Caju. 167

Figura 71 - Foto I - Etapas do processo na Usina do Caju. $\quad 169$

Figura 72 - Foto II - Etapas do processo na Usina do Caju. $\quad 169$

Figura 73 - Foto III - Etapas do processo na Usina do Caju. 170 


\section{Siglas}

ABNT - Associação Brasileira de Normas Técnicas

ACV - Avaliação do ciclo de vida

BNDES - Banco Nacional de Desenvolvimento Econômico e Social

CDR - Combustível derivado de resíduo

CETESB - Companhia de Tecnologia de Saneamento Ambiental

CGU - Controladoria Geral da União

CIDE - Fundação Centro de Informações e Dados

COMLURB - Companhia Municipal de Limpeza Urbana do Rio de Janeiro CONSEMAC - Conselho Municipal de Meio Ambiente da Cidade do Rio de Janeiro

CONAMA - Conselho Nacional de Meio Ambiente

DA - Digestão anaeróbia

DQO - Demanda química de óxigênio

ETA - estação de tratamento de água

ETE - estação de tratamento de esgoto

EU - European Union

EUA - Estados Unidos da America

FGV - Faculdade Getúlio Vargas

FSESP - Fundação Serviço Especial de Saúde

FUNASA - Fundação Nacional de Saúde

GEE - Gases com Efeito de Estufa

GNV - Gás natural veicular

IBAMA - Instituto Brasileiro do Meio Ambiente e dos Recursos Naturais

Renováveis.

IBGE - Instituto Brasileiro de Geografia e Estatística

INEA - Instituto Estadual de Ambiente

IPTU - Imposto Territorial Urbano

INP - Instituto Nacional do Plástico

IQC Índice da Qualidade das Unidades de Compostagem

ISO - International organization for standardization

MDL - Mecanismo de desenvolvimento limpo

NBR Norma Brasileira

$\mathrm{P} / \mathrm{C}$ - Papel/cartao

PEAD - Polietileno de Alta Densidade

PERSU - Plano Estratégico para Resíduos Sólidos Urbanos de Portugal

PET - Politereftalato de Etileno

PEV - Ponto de Entrega Voluntária

PIB - Produto interno bruto

PMGIRS- Plano Municipal de Gestão Integrada de Resíduos Sólidos.

PNRS - Política Nacional de Resíduos Sólidos

PNSB - Pesquisa Nacional de Saneamento Básico

$P P$ - Polipropileno

PPA - Plano Plurianual

PPRU - Plano de Prevenção de Resíduos Urbanos

RE - Resíduos de Embalagem

RSU - Resíduos Sólidos Urbanos

RUC - rejeitos de usinas de compostagem

SF - Separador Focault 
SM - Separador magnético

SNIS - Sistema Nacional de Informações sobre Saneamento

SPR - separação de resíduos para reciclagem

TB - Tratamento Biológico

TM - Tratamento Mecânico

TMB - Tratamento Mecânico e Biológico

UE - União Européia

UTMB - Unidade de Tratamento Mecânico e Biológico 
"Só quando a última árvore for derrubada, o último peixe for morto e o último rio for poluído é que o homem perceberá que não pode comer dinheiro." Provérbio Indígena

"O desenvolvimento humano só existirá se a sociedade civil afirmar cinco pontos fundamentais: igualdade, diversidade, participação, solidariedade e liberdade." Herbert de Souza - Betinho

\section{INTRODUÇÃO}

O progresso da humanidade e o incentivo ao consumismo cada vez maior têm gerado a oferta e o consumo maciço de produtos. Em maior 
proporção, cresce também a produção de resíduos no mundo que, aliado à escassez de recursos não renováveis em longo prazo e às alterações climáticas, têm desviado a atenção para práticas ambientalmente sustentáveis no que envolve a gestão do lixo.

Neste contexto, a Gestão de Resíduos Sólidos Urbanos (RSU), traduz-se num processo complexo que exige visões multidisciplinares, atuando desde a Logística no processo de coleta, armazenagem e destinação de resíduos até a Biologia, Química e Termodinâmica, dada a diversidade de técnicas e tecnologias disponíveis para seu tratamento e valorização no mercado.

O desenvolvimento social também é um ponto relevante, já que em países como o Brasil a reciclagem é uma atividade que gera recursos para classes sociais de menor poder aquisitivo. Além da atuação na produção de bens de consumo a partir do lixo, grande parte dos materiais recicláveis retorna ao mercado devido ao trabalho dos catadores, pessoas de baixíssimo poder aquisitivo, que encontram nesta profissão uma forma de sobrevivência.

Tais fatores são relevantes na implementação de qualquer Sistema de Gestão, que demanda importante participação e investimento dos Poderes Públicos, tanto em nível legislativo como executivo.

Países desenvolvidos, como os membros da União Europeia (UE), estão muito à frente na Gestão de RSU, buscando formas de tratamento dos seus resíduos cada vez menos impactantes ao Meio Ambiente.

O Brasil ainda encontra-se numa fase mais técnica e menos prática que a UE, porém apresenta avanços importantes. Em 2010, entrou em vigor a Política Nacional de Resíduos Sólidos (PNRS), instituída pela Lei 12.305.

Esta Lei estabelece estratégias e prazos para o desenvolvimento sustentável brasileiro, revisa a hierarquia de prioridades no tratamento de resíduos e impõe o sistema de logística reversa, além de tratar do ciclo de vida dos produtos e incentivar o reuso, a reciclagem de materiais e a compostagem de resíduos, eliminando os lixões e deixando de fomentar a disposição em aterros, ficando para este somente resíduos sem outra destinação mais favorável ao meio ambiente e à economia de recursos.

O gerenciamento de resíduos que antes da publicação da PNRS era um assunto cada vez mais discutido pelos gestores públicos, passou a fazer parte de planos de metas dos Estados e municípios, ganhando mais importância nos processos de planejamento governamentais, fator impactante para o desenvolvimento de ações que fomentem práticas de cunho ambiental.

Mesmo com a Política Nacional de Resíduos Sólidos em vigor, o cumprimento de metas estabelecidas demandará muito tempo, pois envolve uma drástica mudança de cultura da população e necessita 
principalmente de apoio direto do Poder Público, gerando maior envolvimento de mão de obra técnica, destinação de verba significativa, necessidade de parceria entre municípios e continuidade em projetos, pontos críticos da Gestão Pública brasileira.

Visando o atendimento das metas ambientais em menor prazo, o objetivo desta dissertação é apresentar e analisar o Tratamento Mecânico e Biológico de resíduos (TMB) como uma opção para a melhoria da gestão de resíduos sólidos urbanos do município do Rio de Janeiro de forma sustentável, sem deixar de atender à PNRS.

Tal processo é utilizado com sucesso nos países membros da UE, apresentando inúmeras vantagens, como a obtenção de maior volume de resíduos recicláveis atuando em concomitância com a coleta seletiva, a redução do volume de resíduos para aterros, com ganhos logísticos e aumentando assim a vida útil destes, além do tratamento dos resíduos orgânicos, gerando composto agrícola e energia a partir do biogás.

Para tanto, pretende-se analisar o cenário atual no que diz respeito à Gestão de Resíduos Sólidos Urbanos no âmbito nacional, estadual e no município do Rio de Janeiro, apresentando estudos de caso de locais que iniciaram a utilização do TMB no Brasil, como também exemplos internacionais, buscando assim avaliar vantagens e desvantagens deste processo, levantando pontos críticos para a aplicação desta tecnologia.

Dada a escassez de experiência nacional neste assunto, a metodologia utilizada para estudo foi baseada em ampla revisão bibliográfica, utilizando livros, artigos científicos e internet.

Para definição do cenário do município do Rio de Janeiro e análise de estudos de caso, foram realizadas também entrevistas com especialistas e pesquisas de campo em Centrais de Triagem e Usinas em operação.

Este trabalho está estruturado em cinco capítulos. Após a presente introdução e objetivos de estudo, o capítulo 2 apresenta a revisão bibliográfica sobre os principais temas abordados na dissertação: os resíduos sólidos urbanos, suas classificações e formas de destinação e o tratamento mecânico e biológico.

O capítulo 3 aborda o cenário geral da gestão de resíduos, partindo da situação brasileira até seu desdobramento no Estado e município do Rio de Janeiro. Estes cenários apresentam índices sobre a geração de resíduos, o mercado de reciclagem, fluxos de processo, envolvimento com cooperativas, bem como os objetivos atuais e futuros.

Para o município do Rio de Janeiro, o estudo aborda a execução do Plano Municipal de Gestão Integrada de Resíduos Sólidos (PMGIRS) na prática, discutindo as dificuldades envolvidas, de acordo com as pesquisas de campo e entrevistas realizadas. 
O capítulo 4 avalia a aplicação da tecnologia TMB no município, apresenta estudos de caso nacionais e um estudo de caso de Portugal.

O quinto e último capítulo apresenta as conclusões da proposta, limitações da pesquisa e sugestões de estudo futuras. 
De acordo com a Política Nacional de Resíduos Sólidos (PNRS, 2010), resíduo sólido define-se como:

[...] material, substância, objeto ou bem descartado resultante de atividades humanas em sociedade, a cuja destinação final se procede, se propõe proceder ou se está obrigado a proceder, nos estados sólido ou semissólido, bem como gases contidos em recipientes e líquidos cujas particularidades tornem inviável o seu lançamento na rede pública de esgotos ou em corpos d'água, ou exijam para isso soluções técnica ou economicamente inviáveis em face da melhor tecnologia disponível.

Os rejeitos são definidos como resíduos sólidos que, depois de esgotadas todas as possibilidades de tratamento e recuperação por processos tecnológicos disponíveis e economicamente viáveis, não apresentem outra possibilidade que não a disposição final ambientalmente adequada. (Plano Nacional de Resíduos Sólidos, 2011)

\subsection{Classificação dos resíduos}

Como estes itens são de extrema heterogeneidade, existem diversas formas de tratamento de suas parcelas e de classificação, conforme abaixo (SAROLDI, 2005):

- Natureza Física: seco e molhado;

- Composição Química: matéria orgânica e matéria inorgânica;

- Origem;

- Riscos potenciais ao Meio Ambiente;

- Grau de degradabilidade.

Algumas classificações serão abordadas detalhadamente a seguir.

\subsubsection{Classificação do resíduo quanto à origem}

Schalch, 1992, com base na NBR 10004 de 1987, apresenta a classificação dos resíduos sólidos de acordo com sua origem, subdividindo em 4 (quatro) grupos: urbanos, industriais, radioativos e agrícolas.

Os urbanos ainda são detalhados em mais 4 (quatro) grupos: domiciliar, comercial, de varrição e de serviços. A Figura 1 a seguir apresenta esta classificação de forma esquemática.

Já a PNRS (2010) apresenta esta classificação conforme a seguir.

- resíduos domiciliares - são originados por atividades residenciais, em localidades urbanas;

- resíduos de limpeza urbana - originados da varrição, limpeza de logradouros, vias públicas e outros serviços de limpeza urbana;

- resíduos sólidos urbanos (RSU) - englobam os resíduos domiciliares e de limpeza urbana;

- resíduos dos serviços públicos de saneamento básico - os gerados nestas atividade, com exceção dos RSU; 
- resíduos industriais: os gerados nos processos produtivos e de instalações industriais;

- resíduos de serviços de saúde: os gerados nos serviços de saúde, conforme definido em regulamento ou em normas estabelecidas pelos órgãos do Sisnama e do SNVS;

- resíduos da construção civil: os gerados nas construções, reformas, reparos, demolições de obras e preparação de terrenos para a Construção Civil;

- resíduos agrossilvopastoris: os gerados nas atividades agropecuárias e silviculturais, incluindo os relacionados a insumos utilizados nessas atividades;

- resíduos de serviços de transportes: os originários de portos, aeroportos, terminais alfandegários, rodoviários e ferroviários e passagens de fronteira;

- resíduos de mineração: os gerados na atividade de pesquisa, extração ou beneficiamento de minérios;

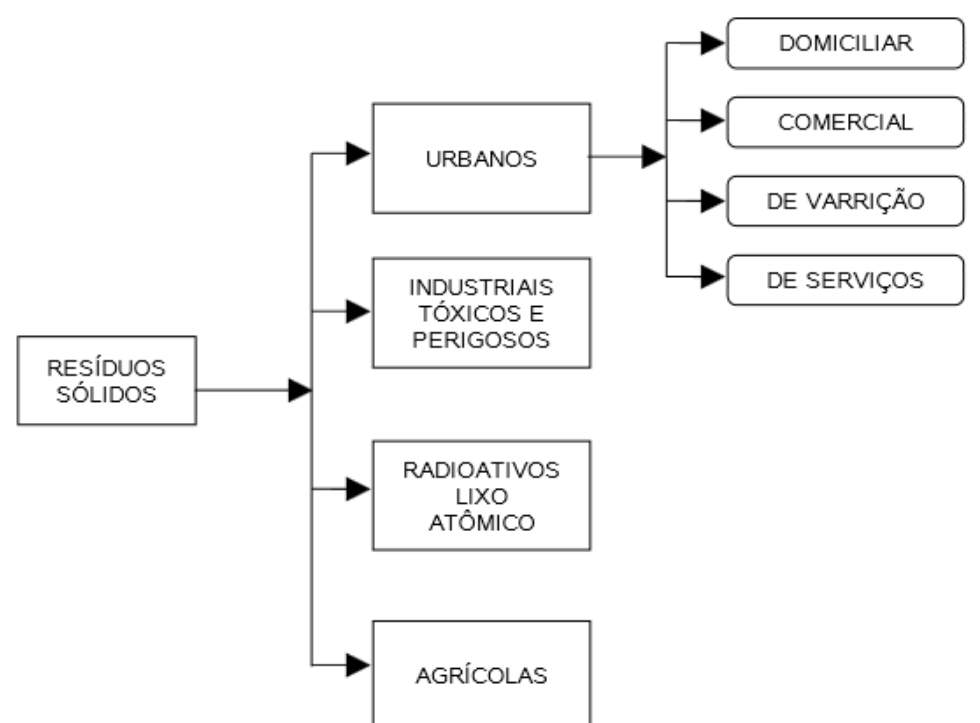

Figura 1 - Classificação dos RSU segundo a sua origem.

Fonte: SCHALCH, 1992.

\subsubsection{Classificação do resíduo quanto aos Riscos Potenciais ao Meio Ambiente}

A NBR 10004 de 2004 apresenta nova versão da classificação, esta mais voltada ao gerenciamento dos materiais.

a) Resíduos classe I - Perigosos - se enquadram resíduos de acordo com os critérios de periculosidades estabelecidos pela norma (inflamabilidade, corrosividade, reatividade, toxicidade, patogenicidade).Os resíduos industriais perigosos devem ter destinação final diferenciada e severamente monitorada de modo a evitar danos ao meio ambiente. 
b) Resíduos classe II A - Não perigosos e não inertes - podem ter propriedades, tais como: biodegradabilidade, combustibilidade ou solubilidade em água. Estão incluídos nesta categoria os papéis, papelão, restos vegetais e outros.

c) Resíduos classe II B - Não perigosos e inertes - Quaisquer resíduos que, quando amostrados de uma forma representativa, segundo a ABNT NBR 10007, e submetidos a um contato dinâmico e estático com água destilada ou deionizada à temperatura ambiente, conforme ABNT NBR 10006, não tiverem nenhum de seus constituintes solubilizados a concentrações superiores aos padrões de potabilidade de água, excetuando-se aspecto, cor, turbidez, dureza e sabor. Se enquadram os tijolos, rochas, vidros e outros.

Vale destacar o capítulo 4.2.1.5.2 dessa Norma, que informa especificidades de resíduos da coleta domiciliar e sua possível patogenicidade:

[...]"Os resíduos gerados nas estações de tratamento de esgotos domésticos e os resíduos sólidos domiciliares, excetuando-se os originados na assistência à saúde da pessoa ou animal, não serão classificados segundo os critérios de patogenicidade."

\subsubsection{Classificação do resíduo quanto ao Grau de degradabilidade}

Outra forma de classificação está relacionada ao grau de degradabilidade, conforme a seguir.

a) Facilmente degradáveis: matéria orgânica presente nos resíduos sólidos de origem urbana;

b) Moderadamente degradáveis: papéis, papelão e material celulósico;

c) Dificilmente degradáveis: pedaços de pano, retalho, aparas e pedaços de serragem de couro, borracha e madeira.

d) Não degradáveis: vidro, metais, plásticos, pedras, solo, entre outros. (BIDONE \& POVINELLE, 1999).

De acordo com o INP, com base na norma ABNT NBR 15448-2 (2008), para que um item plástico possa ser considerado biodegradável, ele precisa se degradar dentro de um período de tempo que não pode exceder a 180 dias, de acordo com as normas internacionais.

Os resíduos orgânicos, de fácil degradação, ainda são os maiores constituintes dos resíduos domiciliares nos países em desenvolvimento, como o Brasil, porém a quantidade de resíduos provenientes de embalagens cresce a cada dia.

Existem outros materiais em comercialização no Brasil, como o Plástico Verde (polietileno verde I'm green ${ }^{\mathrm{TM}}$ ), polímero originado de matéria prima 
renovável, o etanol produzido a partir da cana de açúcar. Porém este item também possui as mesmas propriedades do polietileno originado de combustíveis fósseis, ou seja, não é biodegradável e não compostável (BRASKEM, 2014).

Cresce também, a partir da década de 80, o lixo eletrônico: computadores, celulares e seus periféricos (baterias, carregadores), televisores e outros tantos aparelhos e componentes eletrônicos. (CAPELINI, 2007).

\subsection{Propriedades Físicas, Químicas e Biológicas dos Resíduos Sólidos Urbanos}

É extremamente importante entender as propriedades físicas dos RSU, fatores que influenciam diretamente na eficiência de qualquer processo de destinação, reaproveitamento ou reuso destes.

Tais classificações irão orientar os procedimentos necessários à obtenção dos parâmetros que governam o comportamento da massa de lixo.

A classificação dos resíduos baseada em suas características físicas são a composição gravimétrica, distribuição granulométrica, teor de umidade, temperatura, peso específico e permeabilidade, detalhadas a seguir.

\subsubsection{Composição Gravimétrica}

A composição física ou gravimétrica define o percentual dos diversos componentes presentes no lixo. Normalmente espelha o nível de renda da população.

Deste modo, é de se esperar que regiões mais ricas apresentem, por exemplo, um menor percentual de material orgânico em consequência de uma menor manipulação de alimentos, isto é, maior utilização de alimentos semi-prontos.

Em contrapartida, os percentuais de vidro e de materiais plásticos tendem a ser mais elevados.

Neste contexto, a fase sólida dos RSU é constituída por uma mistura de materiais de diferentes tipos, formas e dimensões, tais como, papel, plástico, papelão, tecidos, borracha, madeira, vidro, metais, resíduos alimentares e de feiras, entulho e outros.

A composição do RSU é muito heterogênea e pode variar de pequenos materiais orgânicos até grandes materiais inorgânicos (NASCIMENTO, 2007). 
De acordo com Saroldi (2005), após a separação do material, pesa-se cada tipo de resíduo e calcula-se a percentagem na composição total do lixo, como exemplo, o papel:

$$
\text { Papel }(\%)=\frac{\text { peso da fração de papel }(\mathrm{kg}) \times 100}{\text { peso total da amostra }(\mathrm{kg})}
$$

Com base na composição gravimétrica, é determinado o teor de matéria orgânica, que ao se degradar, influi nos parâmetros geotécnicos da massa do lixo, pois envolve processos físicos, químicos e biológicos, nos quais a ação de bactérias e microorganismos é dominante, apresentando a geração de gás, chorume e composição química. Processa em cinco fases distintas.

Fase I - Aeróbia - Essa fase que exige a presença de oxigênio $\left(\mathrm{O}_{2}\right)$ é de curta duração. É uma reação exotérmica, na qual há geração de calor. O oxigênio é consumido juntamente com nitratos, gerando $\mathrm{CO}_{2}$ e alguns produtos, resultados da decomposição. O chorume gerado apresenta elevadas concentrações de cloretos e sulfatos e Demanda Química de Oxigênio (DQO) da ordem de 10.000 a 100.000 mg/l.

Fase II - Anaeróbia Ácida - Fase que prescinde da presença de oxigênio $\left(\mathrm{O}_{2}\right)$ e na qual se verificam os processos de hidrólise e formação de ácidos, com o surgimento de bactérias facultativas. O chorume gerado apresenta pH ácido, elevados DQO e teores de amônia, cálcio, ferro e ácidos orgânicos.

Fase III - Anaeróbia metanogênica instável ou acelerada - caracteriza-se pela lenta formação de metano, com surgimento de bactérias metanogênicas, $\mathrm{pH}$ elevado e diminuição da DQO.

Fase IV - Anaeróbia metanogênica estável - verifica-se alta e estável taxa de produção de metano.

Fase V - Metanogênica em declínio ou desacelerada - existência de significativa alta do $\mathrm{pH}$ e a taxa de metano, É controlada pela hidrólise dos sólidos.

\subsubsection{Distribuição granulométrica}

De acordo com Nascimento (2007), a granulometria é a distribuição, em porcentagem, dos diversos tamanhos de grãos. É a determinação das dimensões das partículas do agregado e de suas respectivas porcentagens de ocorrência.

Seu índice é determinado através de peneiramento, utilizando peneiras com determinada abertura constituindo uma série padrão, determinadas por órgãos de referência, como o MIT - Instituto de Tecnologia de 
Massachusetts, e o Sistema de Classificação da ABNT - Associação Brasileira de Normas Técnicas, no Brasil.

Existem inclusive normas ABNT para determinação de distribuição granulométrica de resíduos, como a NBR 15116 (Agregados reciclados de resíduos sólidos da construção civil - Utilização em pavimentação e preparo de concreto sem função estrutural - Requisitos) e NBR 10004/2004 (Resíduos sólidos - Classificação).

Devido à grande heterogeneidade e variedade dos resíduos sólidos urbanos, um procedimento para determinação da distribuição das dimensões de seus componentes é bastante limitado.

As diferentes granulometrias devem ser atribuídas ao maior grau de composição do lixo, de acordo com a profundidade da amostra.

Neste caso, após um pré-tratamento mecânico biológico, em que os resíduos foram previamente triturados e homogeneizados, certa similaridade com os solos pode ser observada em sua distribuição granulométrica.

Para uma primeira aproximação, tem-se procurado correlacionar os componentes individuais do resíduo a diâmetros equivalentes (TCHOBANOGLOUS et al.. 1993).

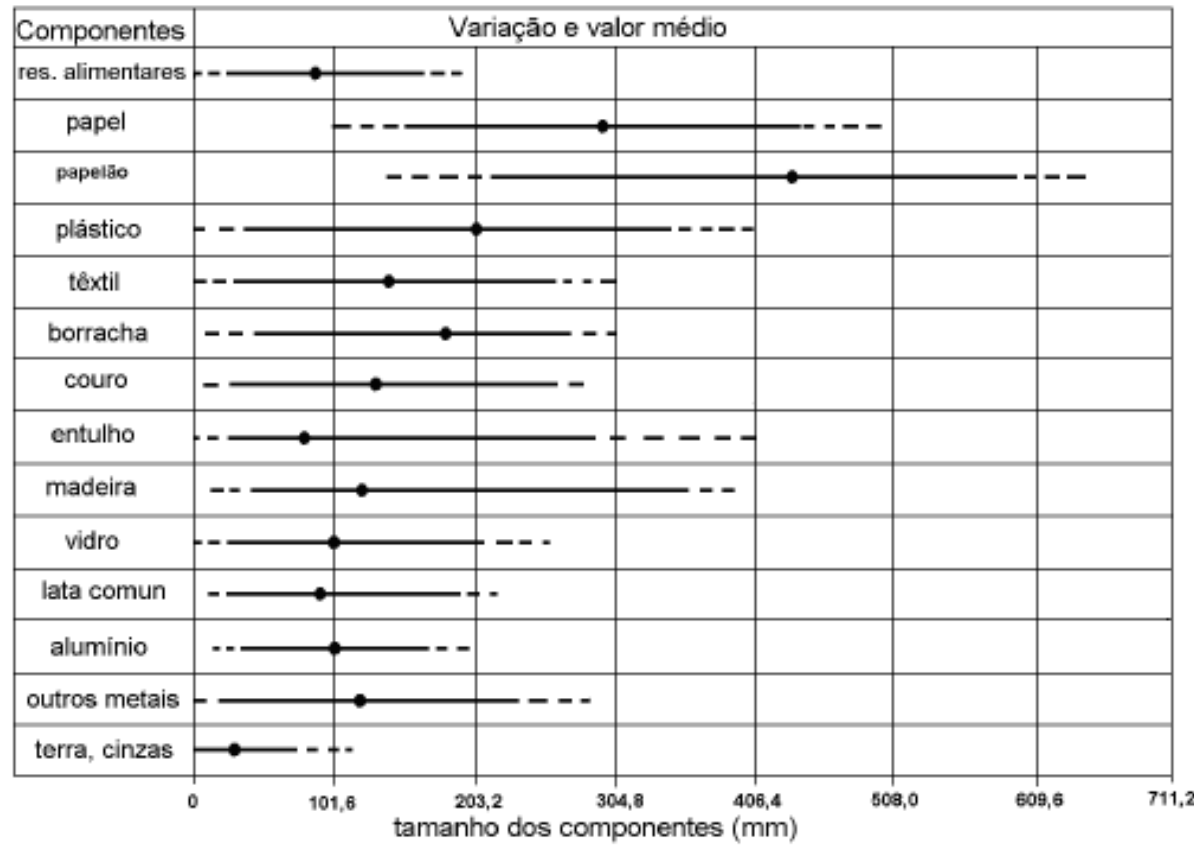

Figura 2 - Diâmetros equivalentes dos componentes de RSU. Fonte: TCHOBANOGLOUS et al, 1993.

Muitos pesquisadores têm utilizado o processo clássico do peneiramento e traçado a curva de distribuição dos tamanhos dos grãos. 
Segundo Knochenmus et al. (1998), o tamanho dos constituintes pode variar entre partículas com dimensões de pedregulho até partículas com dimensões inferiores a $0.075 \mathrm{~mm}$.

Existe, contudo uma tendência no aumento da porcentagem da fração mais fina do RSU com o tempo, como resultado da biodegradação da matéria orgânica (KNOCHENMUS et al.,1998).

\subsubsection{Teor de umidade}

Tal propriedade, como o próprio nome informa, é representa a quantidade de água contida no lixo por unidade de volume, influenciando os sistemas de geração ou recuperação de energia, bem como os processos biológicos onde atua na velocidade de decomposição dos materiais biodegradáveis (SAROLDI, 2005).

De acordo com Carvalho (1999), o teor de umidade do RSU, dentre todas as outras propriedades, talvez seja a que apresente a maior quantidade de fatores que possam influenciar no seu valor, que depende da sua composição inicial, condições climáticas locais do processo de operação, da taxa de decomposição biológica, da capacidade e funcionamento dos sistemas de coleta de líquidos percolados e do sistema de liner de recobrimento.

Os teores de umidade e de material seco são obtidos pelas análises de amostras. A amostragem deve ser a mais representativa possível. Devese pesar a amostra e secá-la em estufa numa faixa de temperatura entre 100 e $103^{\circ} \mathrm{C}$, até obter peso constante.

Como exemplo, num mesmo aterro sanitário o teor de umidade pode variar significativamente entre um ponto e outro, tornando-se relevante a obtenção do perfil de umidade com a profundidade, o qual pode ser obtido através de amostras representativas em estufa ou de outros métodos de determinação da umidade, como da sonda de nêutrons (CARVALHO, 1999).

Quando se trata de RSU, a umidade é expressa tanto em base seca, como adotado em geotecnia. ou seja, $w=\left(M_{w} / M_{s} \times 100(\%)\right.$, como em base úmida, $\mathrm{w}_{\mathrm{w}}=\left(\mathrm{M}_{\mathrm{w}}, \mathrm{M}\right) \times 100(\%)$.

Onde:

W - teor de umidade.

$\mathrm{W}_{\mathrm{w}}$ - teor de umidade, base úmida.

$\mathrm{M}_{\mathrm{w}}$ - massa úmida.

$\mathrm{M}_{\mathrm{s}}$ - massa sólida.

$\mathrm{M}$ - massa total.

Os dois índices estão relacionados, pois $w_{w}=w /(1+w)$. 
É importante especificar o tipo de umidade que se está utilizando, pois dependendo da área de estudo, será mais comum utilizar-se de uma ou outra forma de representação (CARVALHO, 1999).

Existe uma grande variação nos valores de umidade entre os diferentes componentes do RSU, sendo a matéria orgânica responsável pelos maiores valores encontrados.

Segundo Knochenmus et al. (1998), o teor de umidade do RSU é basicamente 0 resultado de altas porcentagens de lixo orgânico e o seu valor tende a aumentar com o aumento do conteúdo orgânico do material.

Azevedo et al.(2003) comprovam esse fato, apresentando resultados de teores de umidade para resíduos de diversas idades do aterro de Santo André, São Paulo, onde observaram uma diminuição dos valores com o aumento da idade $(\mathrm{w}(\%)=-0,63 . t$ (meses) $+59,3)$ provavelmente causada pela diminuição da quantidade de matéria orgânica devido à sua decomposição, pois durante o processo há o consumo de água tanto intrínseca (água presente na composição da matéria orgânica) como da água livre.

Os componentes inorgânicos, tais como papéis e produtos plásticos geralmente, têm um teor de umidade abaixo de $10 \%$. Assim, o teor de umidade tende a aumentar com o aumento do conteúdo orgânico do material.

Knochennus et al (1997) relatam que para a maioria dos aterros sanitários nos EUA o teor de umidade varia de $15 \%$ a $40 \%$, dependendo da composição do lixo, da estação do ano, da umidade natural e das condições climáticas. Afirmam ainda, que em regiões onde a evapotranspiração excede a precipitação, o teor de umidade típico é da ordem de $25 \%$.

\subsubsection{Temperatura}

A temperatura é um dos indicadores das reações bioquímicas que ocorrem no interior da massa de lixo, em função da degradação da matéria orgânica e usualmente medida por metro de profundidade, através de termômetro elétrico-digital (SILVEIRA, 2004).

As temperaturas dos aterros de resíduos sólidos urbanos normalmente variam entre $30^{\circ}$ e $60^{\circ} \mathrm{C}$, apresentando valores crescentes com o aumento da profundidade.

Após profundidades entre 5 e $10 \mathrm{~m}$, estes valores tendem a se estabilizar e a variação da temperatura ambiente perde parte de sua importância, conforme verificado em estudos de Mariano e Jucá (1998), apresentados em Nascimento (2007). 


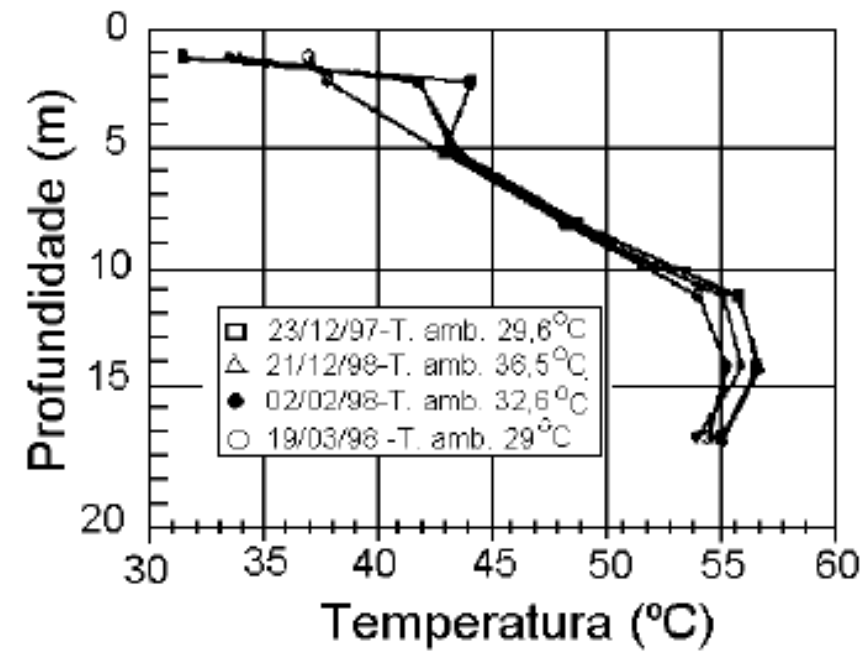

Figura 3 - Variação da temperatura do RSU com a profundidade. Fonte: Nascimento, 2007.

\subsubsection{Peso específico}

Determina-se o peso da unidade de volume de um corpo, que corresponde à relação entre o peso e o volume da amostra, isto é a relação que exprime o peso na unidade de volume (SILVEIRA, 2004).

$$
\begin{aligned}
& \mathrm{P}=\mathrm{m} \times \mathrm{g} \\
& \delta=\frac{\text { Peso }}{\text { Volume }} \\
& \text { Peso }=\mathrm{Kg}^{*} 9.81 \mathrm{~m} / \mathrm{s}^{2} / \mathrm{m}^{3}=\mathrm{KN} / \mathrm{m}^{3} \\
& 1 \mathrm{KN}=1000 \mathrm{~kg} / \mathrm{m} \\
& \delta=\frac{\mathrm{P}}{\mathrm{V}}=\frac{\mathrm{m} \times \mathrm{g}}{\mathrm{V}}=\frac{9,81 \times\left[\mathrm{m}^{2}\right] \times(\mathrm{kg})}{\mathrm{seg}^{3}}= \\
& =\frac{9,81 \times \mathrm{kg} \mathrm{x} \mathrm{m}}{\mathrm{m}^{3} \mathrm{seg}^{2}} \\
& \mathrm{KN}=\frac{\mathrm{kg} \mathrm{x} \mathrm{m}^{2}}{\mathrm{seg}^{2}}
\end{aligned}
$$

Ainda de acordo com Silveira (2004), propriedades como peso específico e permeabilidade devem ser determinadas como função da porosidade, que por sua vez é função do método de deposição, da sobrecarga aplicada e da idade do aterro. Uma grande parte dessas propriedades sofre mudanças significativas com o tempo.

A decomposição da matéria orgânica e os processos de compressão primária e secundária alteram, de forma significativa, seus valores.

Nascimento (2007) comenta que existem várias técnicas para determinação do peso especifico, dentre elas destacam-se os ensaios em poços escavados ( 2 a $4 \mathrm{~m}$ de profundidade) ou trincheira e o emprego da radiação gama. 
Os ensaios em poços consistem na pesagem do material e determinação do volume a partir do preenchimento da cava com água, antes devidamente impermeabilizada com manta sintética.

Devido às características peculiares do RSU, nenhum dos métodos é realmente preciso, podendo haver variações significativas nos resultados obtidos.

O peso específico dos maciços de RSU é influenciado pela composição e umidade do RSU, pelas camadas de cobertura de solo utilizadas diariamente, pelo grau de compactação e pela decomposição e consolidação do resíduo com o tempo.

Em aterros mais antigos, o peso específico depende do grau de decomposição, fatores ambientais e profundidade da amostra. Este geralmente aumenta com a profundidade, como resultado do processo de compressão e bioconsolidaçåo do RSU (KÖNIG \& JESSBERGER. 1997 apud NASCIMENTO, 2007).

Manassero et al. (1996) apud NASCIMENTO (2007) apresentaram valores de pesos específicos em função do grau de compactação dos aterros: 3 a $9 \mathrm{kN} / \mathrm{m}^{3}$ para aterros mal compactados, de 5 a $8 \mathrm{kN} / \mathrm{m}^{3}$ para moderadamente compactados e de 9 a $10,5 \mathrm{kN} / \mathrm{m}^{3}$ para aterros bem compactados.

Os pesos específicos obtidos para os resíduos sólidos urbanos aterrados apresentam uma ampla faixa de variação, desde pequenos valores como $3 \mathrm{kN} / \mathrm{m}^{3}$, para aterros não compactados a pobremente compactados, até valores como $17 \mathrm{kN} / \mathrm{m}^{3}$. para aterros com alto grau de compactação (KÖNIG \& JESSBERGER.1997 apud NASCIMENTO, 2007).

Carvalho (1999) relata as dificuldades em se determinar o peso específico do RSU em campo. Em seu trabalho, foram encontrados valores de peso específico entre 8 e $15 \mathrm{kN} / \mathrm{m}^{3}$, por meio da pesagem de material obtido de furos de sondagem e da estimativa do volume do furo. Comenta da imprecisão na determinação destes valores, porém observa a tendência do aumento do peso específico com a profundidade.

Resultados de Azevedo et al. (2003) comprovam o aumento do peso específico do RSU com a idade.

\subsubsection{Permeabilidade}

Define-se permeabilidade como a característica de um meio poroso permitir um líquido fluir entre suas partículas com maior ou menor velocidade. Representa o tempo necessário para que um líquido percorra os vazios de uma massa de solo, ou de resíduos (SILVEIRA, 2004).

As normas para implantação de aterros de RSU exigem sua deposição em camadas, sistema de controle e coleta de chorume in situ. 
Neste caso as características hidráulicas do lixo são importantes, devido à migração incontrolada do chorume e do problema de estabilidade, pois a tensão efetiva que comanda a resistência depende da pressão neutra, que depende das tensões provocadas pela percolação de líquidos dentro do meio poroso (PINTO, 2000), correspondente à massa de lixo.

A determinação do coeficiente de permeabilidade $(k)$ é de fundamental importância para o dimensionamento dos sistemas de drenagem interna de chorume e gás dos aterros sanitários de RSU.

A permeabilidade é normalmente avaliada por meio de ensaios de laboratório e ensaios in situ, executados em trincheiras e poços escavados de grande diâmetro ou em furos de sondagem. Carvalho (1999) apresenta dados de condutividade hidráulica de RSU publicados por vários autores (Tabela abaixo).

Knochenmus et al (1998) comentam que a permeabilidade de um maciço de RSU é altamente dependente do procedimento de aterramento, grau de compactação, idade e composição do RSU e portanto deve ser determinada caso a caso.

Manassero et al. (1996) sugere o uso de um coeficiente de permeabilidade de $10 \mathrm{~cm} / \mathrm{s}$ como uma primeira aproximação nos projetos, enquanto Briggs (2001), informa que a condutividade hidráulica deve ser estudada caso a caso, porém uma primeira aproximação que pode ser sugerida é de $10^{-5} \mathrm{~cm} / \mathrm{s}$.

A diferença entre os coeficientes sugeridos por cada autor é bastante relevante, conforme os citados acima e os demais apresentados na Tabela 1, comprovando a dificuldade para a determinação do coeficiente de permeabilidade, que apresenta inúmeras dificuldades em virtude do caráter heterogêneo do RSU.

Realizando ensaios de perda d'água em furos de sondagem, Simões et al. (2003) avaliaram a permeabilidade do resíduo da Central de Tratamento de Resíduos Sólidos em Belo Horizonte, obtendo para este resíduo valores situados na faixa de $10 \mathrm{~cm} / \mathrm{s}$.

Outros fatores importantes para o estudo da permeabilidade são a compactação e as características do lixo, com destaque para a idade. 


\begin{tabular}{|c|c|c|c|}
\hline Referência & $\begin{array}{c}\text { Peso } \\
\text { especifico } \\
\left(\mathrm{kN} / \mathrm{m}^{2}\right)\end{array}$ & $\begin{array}{c}\text { Coeficiente de } \\
\text { permeabilidade } \\
\text { (m/s) }\end{array}$ & Método de ensaio \\
\hline Fungaroli et al. (1979) & $1,1-4$ & $1 \times 10^{-5}-2 \times 10^{4}$ & Determinaçäo em lisímetros \\
\hline Koriates et al. (1983) & 8,6 & $3,15 \times 10^{-5}-5,10 \times 10^{-5}$ & Ensaio de laboratório \\
\hline Oweis \& Khera (1986) & 6,45 & $1 \times 10^{-5}$ & Estimativa de dados de campo \\
\hline \multirow[t]{2}{*}{ Oweis et al. (1990) } & $\begin{array}{c}6,45 \\
9,4-14\end{array}$ & $\begin{array}{c}1 \times 10^{-5} \\
1,5 \times 10^{6}\end{array}$ & \multirow{2}{*}{$\begin{array}{l}\text { Ensai de bombeamento } \\
\text { Ensaio de campo com carga } \\
\text { variável } \\
\text { Ensaio em poço }\end{array}$} \\
\hline & $6,3-9,4$ & $1,1 \times 10^{5}$ & \\
\hline Landva \& Clark (1990) & $10,1-14,4$ & $1 \times 10^{-5}-4 \times 10^{4}$ & Ensaio em poço \\
\hline Gabr \& Valero & - & $1 \times 10^{-7}-1 \times 10^{5}$ & Ensaio de laboratónio \\
\hline Blengino et al. (1996) & $9-11$ & $3 \times 10^{-7}-3 \times 10^{8}$ & $\begin{array}{l}\text { Ensaio de campo em furos } \\
\text { profundos }(30-40 \mathrm{~m}) \text { e com } \\
\text { carga variável }\end{array}$ \\
\hline Manassero et al. (1990) & $8-10$ & $1,5 \times 10^{-5}-2,6 \times 10^{-4}$ & $\begin{array}{l}\text { Ensaio de bombeamento ( } 15- \\
20 \mathrm{~m} \text { de profundidade) }\end{array}$ \\
\hline Beaven \& Powrie (1995) & $5-13$ & $1 \times 10^{-7}-1 \times 10^{-4}$ & $\begin{array}{l}\text { Ensaio de laboratório com } \\
\text { pressã́o conf. De } 0-600 \mathrm{kPa}\end{array}$ \\
\hline \multirow[t]{2}{*}{ Brandi (1990) } & $11-14$ & $\begin{array}{l}7 \times 10^{e}-2 \times 10^{e} \\
\text { (comp. Rolo) }\end{array}$ & $\begin{array}{l}\text { Ensaio de campo com carga } \\
\text { variável }\end{array}$ \\
\hline & $13-16$ & $\begin{array}{l}5 \times 10^{2}-3 \times 10^{7} \\
\text { (comp. dinámica) }\end{array}$ & Ensaio em poço \\
\hline \multirow[t]{2}{*}{ Brandi (1994) } & $\begin{array}{l}9-12 \\
9-12\end{array}$ & $\begin{array}{l}2 \times 10^{2}-1 \times 10^{6} \\
5 \times 10^{-4}-3 \times 10^{6} \\
\text { (pré-tratado) }\end{array}$ & \multirow[t]{2}{*}{ Ensaio de laboratónio } \\
\hline & $13-17$ & $\begin{array}{l}2 \times 10^{2}-3 \times 10^{5} \\
\text { (muito compactado) }\end{array}$ & \\
\hline Jessberger (1984) & $\begin{array}{l}\text { RSU mist. com } \\
\text { entulho } \\
\text { (ensaio D) }\end{array}$ & $\begin{array}{l}1 \times 10^{-4}-1 \times 10^{-3} \\
3 \times 10^{-4}-1 \times 10^{5}\end{array}$ & $\begin{array}{l}\text { Antes da comp. dinámica } \\
\text { Depois da comp. dinâmica }\end{array}$ \\
\hline Jessberger (1984) & $\begin{array}{l}\text { RSU mist. com } \\
\text { entulho } \\
\text { (ensaio II) }\end{array}$ & $\begin{array}{l}4 \times 10^{-3}-4 \times 10^{-3} \\
1 \times 10^{-3}-1 \times 10^{-4}\end{array}$ & $\begin{array}{l}\text { Antes da comp. dinámica } \\
\text { Depois da comp. dinâmica }\end{array}$ \\
\hline Santos et al. (1998) & $14-19$ & $1 \times 10^{-7}$ & $\begin{array}{l}\text { Ensaio in situ em furo de } \\
\text { sondagem }\end{array}$ \\
\hline Blengino et al. (1996) & - & $3 \times 10^{-7}-2,5 \times 10^{6}$ & $\begin{array}{l}\text { Ensaio in situ em furo de } \\
\text { sondagem }\end{array}$ \\
\hline
\end{tabular}

Tabela 1 - Coeficientes para permeabilidade para o RSU (Carvalho, 1999).

\subsubsection{Poder Calorífico}

Esta característica dos resíduos torna-se cada dia mais importante, já que é fundamental para a avaliação de tecnologias que visem à obtenção de energia a partir do resíduo.

O Poder Calorífico é simplificadamente, a quantidade de energia por unidade de massa armazenada num corpo.

Poder Calorífico Superior (P.C.S) - é dado pela soma da energia liberada na forma de calor e a energia gasta na vaporização da água que se forma numa reação de oxidação. 
Poder Calorífico Inferior (P.C.I.) - dado apenas pelo primeiro termo, isto é, a energia liberada na forma de calor.

De acordo com EPE (2008), o Poder Calorífico Inferior (PCI), normalmente expresso em $\mathrm{kcal} / \mathrm{kg}$, pode ser calculado a partir da expressão matemática formulada por Themelis (2003) com base em estatísticas levantadas em pesquisas de campo:

$\mathrm{PCl}=\left[18.500 * \mathrm{Y}_{\text {combustível }}-2.636\right.$ * $\mathrm{Y}_{\mathrm{H} 2 \mathrm{O}}-628 * \mathrm{Y}_{\text {vidros }}-544$ * $\left.\mathrm{Y}_{\text {metais }}\right] /$ 4,185

Onde as variáveis $Y_{\text {combustivel, }} Y_{\mathrm{H} 2 \mathrm{O}}, Y_{\text {vidros }}$ e $Y_{\text {metais }}$ representam a proporção de cada elemento em $1 \mathrm{~kg}$ de RSU.

É necessário esclarecer que do peso da fração orgânica combustível (putrescíveis, folhas e madeira) deve ser descontado o peso da água contida nesses orgânicos. Este peso da água corresponde, em percentual, à variável $\mathrm{Y}_{\mathrm{H} 2 \mathrm{O}}$, sendo usual, na ausência de dados específicos, a utilização do valor típico de $60 \%$ como estimativa do teor de água.

A Tabela 2 apresenta o poder calorífico de materiais normalmente encontrados em RSU e permite inferir que resíduos sólidos em que predominam orgânicos tendem a apresentar menor poder calorífico.

\begin{tabular}{lc}
\hline \multicolumn{1}{c}{ Material } & kcal/kg \\
\hline Plásticos & 6.300 \\
\hline Borracha & 6.780 \\
\hline Couro & 3.630 \\
\hline Têxteis & 3.480 \\
\hline Madeira & 2.520 \\
\hline Alimentos & 1.310 \\
\hline Papel & 4.030 \\
\hline
\end{tabular}

Tabela 2 - Poder calorífico de materiais encontrados em RSU.

Fonte: EPE, 2008.

Embora a classificação segundo o $\mathrm{PCl}$ não deva ser considerada definitiva para estabelecer a destinação do RSU, considera-se que:

- para $\mathrm{PCl}<1.675 \mathrm{kcal} / \mathrm{kg}$, a incineração não é tecnicamente viável (além de dificuldades técnicas, exige ainda a adição de combustível auxiliar);

- para $1.675 \mathrm{kcal} / \mathrm{kg}<\mathrm{PCl}<2.000 \mathrm{kcal} / \mathrm{kg}$, a viabilidade técnica da incineração ainda depende de algum tipo de pré-tratamento que eleve o poder calorífico;

- para $\mathrm{PCl}>2.000 \mathrm{kcal} / \mathrm{kg}$, a queima bruta ("mass burning") é tecnicamente viável. 


\subsubsection{Classificação Química}

A classificação química do resíduos é baseada principalmente no teor de materiais em sua composição (SAROLDI, 2005):

- $\quad p H$-concentração de íons de hidrogênio em solução, que caracteriza sua acidez ou alcalinidade;

- teor de carbono, teor de hidrogênio, teor de nitrogênio, concentração de cálcio, sódio, potássio e elementos metálicos representa a quantidade em peso de cada um destes elementos na massa do lixo;

- $\quad$ relação carbono/nitrogênio - indica a capacidade dos resíduos em decomposição de se constituírem em compostos orgânicos bioestabilizados, tendo em vista que os microrganismos responsáveis pela decomposição da matéria orgânica necessitam de carbono para seu desenvolvimento e de nitrogênio para a síntese das proteínas;

- $\quad$ salinidade - é uma medida da quantidade de sais existentes em massas de água. A forma mais simples de descrever a salinidade é como a razão entre a quantidade total de sólidos (em massa) dissolvidos e a massa da água que lhe serve de solvente. De acordo com SILVEIRA (2004), os estudos para a determinação da salinidade não obedecem aos procedimentos usados nos ensaios tradicionais, em função da diversidade de granulometria, composição do chorume e pressões no solo.

\subsubsection{Classificação Biológica}

Saroldi (2005) também evidencia a classificação biológica dos resíduos, conforme a seguir:

- $\quad$ Consituintes solúveis em água: açúcares, amido, aminoácidos e vários ácidos orgânicos;

- Semicelulose: resultante da condensação de 5 ou 6 carbonos dos açúcares;

- Celulose: resultante da condensação de 6 átomos de carbono da glicose;

- Gorduras, óleos e graxas: éstereis de álcoois e ácidos graxos de longa cadeia;

- Lignina: polimérico constituído por anéis aromáticos com grupos metoxi $\left(-\mathrm{OCH}_{3}\right)$;

- Lignocelulose: resultante da combinação de lignina e da celulose;

- Proteínas: constituídas por cadeias de aminoácidos.

Ainda sobre características físicas, químicas e biológicas, é importante comentar sobre as propriedades do chorume, líquido altamente poluente, de composição complexa, resultante da dissolução dos componentes orgânicos e inorgânicos dos resíduos pela percolação da água e pela decomposição dos produtos. 
A concentração de metais pesados encontradas no chorume de lixo doméstico ou comercial é baixa. Os metais mais comuns encontrados são: cádmio, chumbo, cobalto, cobre, cromo, ferro, manganês, mercúrio, níquel e zinco.

Uma importante fração orgânica encontrada no chorume de aterro de lixo é constituída por proteínas, carboidratos e lipídios. A análise de poluentes orgânicos encontrados no chorume revela a presença de benzeno, tolueno, acetona e fenol, entre outros.

\subsection{Métodos de destinação final de resíduos}

Avaliando a Gestão de Resíduos Urbanos de forma ampla, a destinação final seria a última fase a ser cumprida com relação a todos os demais processos que envolvem estes materiais. Neste ponto de vista, a implantação de políticas voltadas à redução da produção de resíduos, ao seu reuso e posteriormente à reciclagem, constituem medidas de extrema importância na minimização dos problemas que envolvem a disposição final dos resíduos sólidos urbanos, como por exemplo, na implantação de áreas para aterros. (NASCIMENTO, 2007)

Segundo a Política Nacional de Resíduos Sólidos (2010):

[...]destinação final ambientalmente adequada: destinação de resíduos que inclui a reutilização, a reciclagem, a compostagem, a recuperação e o aproveitamento energético ou outras destinações admitidas pelos órgãos competentes do Sisnama, do SNVS e do Suasa, entre elas a disposição final, observando normas operacionais específicas de modo a evitar danos ou riscos à saúde pública e à segurança e a minimizar os impactos ambientais adversos;

[...] disposição final ambientalmente adequada: distribuição ordenada de rejeitos em aterros, observando normas operacionais específicas, de modo a evitar danos ou riscos à saúde pública e à segurança e a minimizar os impactos ambientais adversos;

Segundo a hierarquia da gestão de resíduos, conforme a Figura 5, as opções adequadas de destino dos resíduos incluem redução, reuso, reciclagem, incineração (para itens não orgânicos) e disposição em aterros. (OLIVEIRA, 2012)

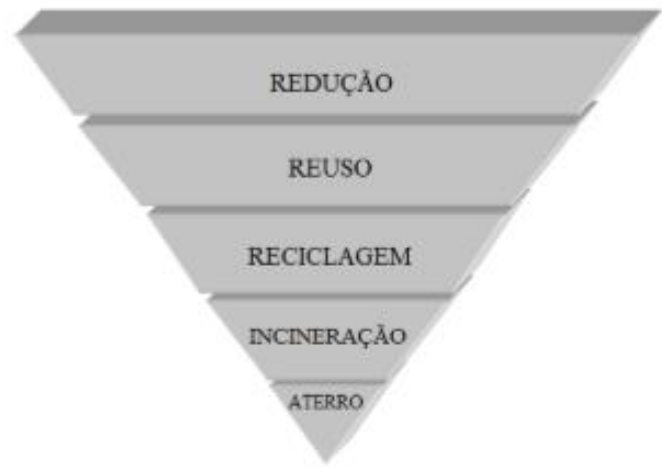

Figura 4 - Hierarquia da Gestão de Resíduos em ordem decrescente de prioridade. Fonte: Oliveira, 2012 
O Artigo 9 da Política Nacional de Resíduos Sólidos (2010) detalha e melhora esta hierarquia:

[...]Art. 9o $\mathrm{Na}$ gestão e gerenciamento de resíduos sólidos, deve ser observada a seguinte ordem de prioridade: não geração, redução, reutilização, reciclagem, tratamento dos resíduos sólidos e disposição final ambientalmente adequada dos rejeitos.

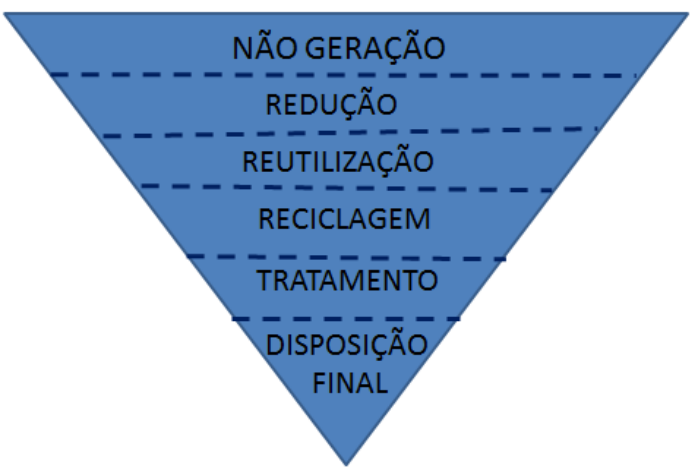

Figura 5 - Hierarquia da Gestão de Resíduos. Adaptado de PNRS (2010).

A redução, conforme o próprio nome diz, são ações, processos ou atividades que tenham como objetivo usar e retirar da natureza somente 0 necessário. Além da diminuição de resíduos e da economia dos recursos naturais, reduzir significa também economia de dinheiro.

O reuso visa a busca por novas utilidades para materiais que supostamente não seriam mais úteis. (STEPHANOU, 2013).

O reuso ou reutilização também pode ser definido como processo de aproveitamento dos resíduos sólidos sem sua transformação biológica, física ou físico-química, observadas as condições e os padrões estabelecidos pelos órgãos competentes do Sisnama e, se couber, do SNVS e do Suasa (PNRS, 2010).

Tais ações visam à redução de impactos ambientais gerados pelos diversos tipos de destinação de resíduos, conforme será detalhado a seguir.

De acordo com a resolução CONAMA ํำ1, de 23 de janeiro de 1986, considera-se impacto ambiental:

[...]qualquer alteração nas propriedades físicas, químicas e biológicas do ambiente causada por qualquer forma de matéria ou energia resultante das atividades humanas, que direta ou indiretamente, afetem: a saúde, a segurança e o bem estar da população; as atividades sociais e econômicas; a biota; as condições estéticas e sanitárias do ambiente e a qualidade dos recursos ambientais. 


\subsubsection{Digestão Anaeróbica}

De acordo com a Nota Técnica DEN 06/08, emitida pela Empresa de Pesquisa Energética (EPE, 2008), digestão anaeróbica (DA) pode ser definida como a conversão de material orgânico em dióxido de carbono, metano e lodo através de bactérias, em um ambiente pobre em oxigênio.

O gás obtido durante a digestão anaeróbica, chamado de biogás, inclui além do metano e do dióxido de carbono, alguns gases inertes e compostos sulfurosos.

A digestão anaeróbica é conseqüência de uma série de interações metabólicas com a atuação de diversos grupos de microorganismos. A produção de metano ocorre em um espectro amplo de temperaturas, mas aumenta significativamente em duas faixas, ditas mesofílica - entre 25$40^{\circ} \mathrm{C}$, e termofílica - entre $50-65^{\circ} \mathrm{C}$.

A maioria dos sistemas de DA necessita de uma fase de pré-tratamento da carga de entrada na qual são separados os resíduos não digeríveis. A separação garante a remoção de materiais recicláveis, como vidros e metais e resíduos indesejáveis.

Para a produção de adubos de alta qualidade, por exemplo, a segregação dos contaminantes deve ser muito mais apurada. Assim, os resíduos recebidos pelo digestor vêm normalmente da coleta seletiva ou de um pré-tratamento mecânico. No caso da coleta seletiva, os materiais recicláveis são separados dos resíduos orgânicos na fonte.

Dentro do digestor a carga é diluída para atingir o teor de sólidos desejado e aí permanece durante o tempo de retenção designado (em torno de 20 dias). Para a diluição, uma ampla variedade de fontes de água pode ser utilizada, como água limpa, água de esgoto ou líquido recirculante do efluente de digestor.

Freqüentemente necessita-se de um trocador de calor a fim de manter a temperatura no vaso de digestão. As impurezas do biogás são retiradas para que o produto esteja de acordo com a necessidade da sua aplicação. No caso de tratamento residual, o efluente do digestor é desidratado e o líquido é reciclado para ser usado na diluição da carga de alimentação. Os bio-sólidos são aerobicamente tratados para a obtenção do produto composto, estabilizados para serem depositados em aterros ou usados como combustível para incineração.

A quantidade de biogás produzida depende, entre outros fatores, da tecnologia empregada na digestão. A usina de Tilburg, na Holanda, por exemplo, pode alcançar $106 \mathrm{~m}^{3} / \mathrm{t}$ de resíduos $(75 \%$ de restos de alimentos e de jardim e $25 \%$ de papel não reutilizável), com um teor de $56 \%$ de metano. 
A KOMPOGAS, fabricante de biodigestores, sugere, como média, o valor de $120 \mathrm{~m}^{3}$ ton de material orgânico. Considerando-se essas referências e a proporção de matéria orgânica na quantidade de RSU gerado por uma comunidade, pode-se afirmar que entre 60 a $75 \mathrm{~m}^{3}$ de biogás são produzidos por tonelada de RSU em um processo de DA..

Da mesma forma que na recuperação de gás do aterro, o biogás pode ser consumido diretamente, situação em que apresenta poder calorífico entre 4.500 e $6.000 \mathrm{kcal} / \mathrm{m}^{3}$ ou tratado para separação e aproveitamento do metano, cujo poder calorífico é semelhante ao do gás natural.

Em termos elétricos, considerando eficiência de 35\% na conversão de energia térmica para energia elétrica, podem ser obtidos entre 120 e 290 kWh por tonelada de RSU, dependendo do conteúdo energético do lixo (proporção de metano no gás produzido pela DA).

Uma vantagem da DA sobre o aproveitamento do gás de aterro é a redução da quantidade de resíduos depositados em aterro sanitário. Com isso, entende-se a vida útil do aterro e a oferta de biogás se regulariza ao longo desse tempo.

De acordo com Teixeira (2009), dependendo da composição do substrato, pode produzir-se normalmente cerca de $200 \mathrm{~m}^{3}$ de biogás por tonelada de fração orgânica digerida.

A estabilização da matéria orgânica dá-se de forma lenta, a temperaturas não muito elevadas e o resíduo obtido deve ser tratado posteriormente para ser considerado um composto de qualidade estável, podendo acontecer através de uma decomposição aeróbia (compostagem).

A digestão anaeróbia necessita de um elevado controle de diversos fatores (temperatura e emissões) e de equipamentos mais desenvolvidos tecnologicamente em relação à maior parte dos processos de compostagem. No entanto, possui algumas vantagens, sobretudo no tempo reduzido de tratamento e da possibilidade de recuperar energia.

\subsubsection{Compostagem}

A compostagem é um processo de tratamento da fração orgânica dos resíduos sólidos urbanos, transformando estes materiais em uma substância com aplicação mais nobre. Tem como objetivo, além da recuperação, o preparo da fração orgânica, favorecendo a ação de agentes biológicos. (NASCIMENTO, 2007).

O composto orgânico gerado do tipo "húmus" pode ser utilizado em atividades de reflorestamento, jardinagem, dentre outros. Este produto não deve ser utilizado como fertilizante, por apresentar baixos teores de macronutrientes (nitrogênio, fósforo e potássio) e de macronutrientes (cobre, cobalto, níquel, zinco, manganês, boro e ferro). 
De acordo com Teixeira (2009), a compostagem constitui um processo biológico que transforma a matéria orgânica num resíduo biológico considerado estável, através da liberação de água, dióxido de carbono, inorgânicos e calor. O processo é aeróbico e realiza-se a elevadas temperaturas causadas pelo calor liberado no processo biológico.

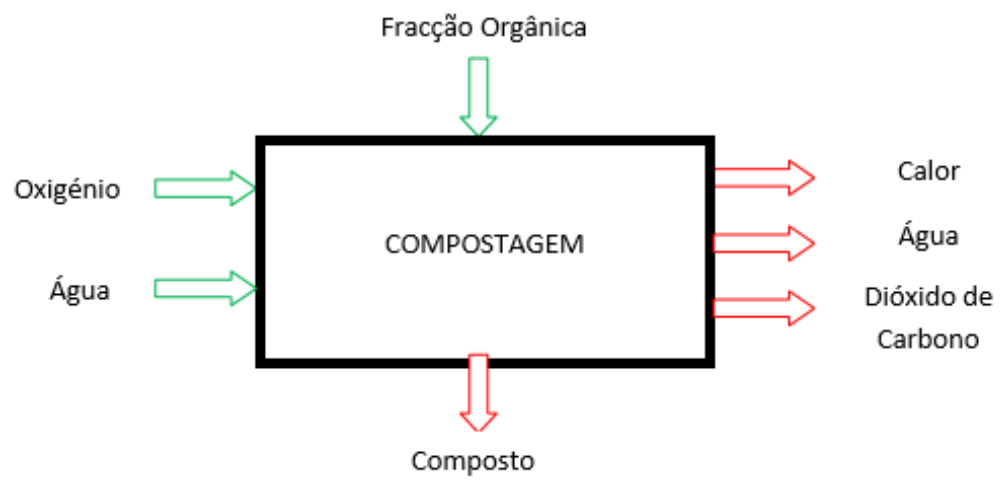

Figura 6 - Tratamento Biológico por Compostagem

Fonte: Teixeira, 2009.

A composição física, química e biológica dos resíduos provenientes da separação mecânica dos RSU é altamente diversificada.

Um dos problemas associados à obtenção de material para compostar desta forma consiste na sua possível contaminação com elementos residuais e inertes, não compostáveis, o que diminui a sua qualidade e aptidão para obter um composto final com qualidade para fins agrícolas. (Teixeira, 2009).

Bidone (1999) coloca que a transformação biológica da matéria orgânica crua biodegradável ao estado de matéria orgânica umidificada dá-se pelo trabalho dos microorganismos que participam do processo de compostagem. As bactérias, os fungos e os actinomicetos são os principais microorganismos responsáveis por este processo.

A matéria orgânica é disposta em leiras, com temperatura controlada entre $45^{\circ}$ e $65^{\circ} \mathrm{C}$. Mantém-se um reviramento sistemático e periódico, manual ou mecânico, a fim de promover aeração, evitando a proliferação de moscas e mau odor.

Se a umidade for insuficiente, durante o revolvimento é feita a irrigação com chuveiros de crivos finos com água bruta de boa qualidade. $O$ tempo usual do processo é de 3 a 4 meses.

Este tempo pode ser reduzido se utilizado o método de leira estática acelerada, em que a compostagem é realizada com insuflamento de ar forçado na massa em degradação. Neste método, o material estará completamente umidificado em 2 meses (SAROLDI, 2005).

Para que o processo ocorra da melhor forma é muito importante a quantidade de materiais fermentáveis, mas também a existência de 
materiais inorgânicos como terra, vidro e metais, possui um papel relevante, uma vez que contêm uma grande porcentagem de substâncias alcalinas que podem neutralizar os ácidos gerados durante o processo de decomposição.

Outros fatores que ajudam a aferir a evolução do processo de compostagem são o cheiro, a cor, a textura ou granulometria, pois dão indicações sobre o estado e condições de evolução do composto.

Outro fator muito importante para aferir a qualidade dos corretivos orgânicos é a análise dos quantitativos de metais pesados, tendo em conta que constituem o principal fator limitante ao uso de composto orgânico proveniente dos RSU.

Também não se deve desconsiderar a importância de outros aspectos como a quantidade de inertes (particularmente o vidro) e de compostos orgânicos tóxicos de degradação lenta (detergentes, pesticidas, fenóis, hidrocarbonetos) que estejam presentes no composto.

Apesar de a compostagem ser um processo simples e por este motivo utilizado por pequenas comunidades, nem sempre é bem realizado, causando descrédito na opinião pública em geral.

Tal fato pode ocorrer devido aos elevados custos operacionais, pela complexidade excessiva de muitos sistemas de tratamento e pela baixa qualidade do composto produzido, que poderá eventualmente causar riscos para o ambiente e para a saúde pública.

É importante citar que qualquer estação de compostagem necessita de um aterro sanitário de apoio, utilizado para a deposição dos resíduos não compostáveis nem recicláveis, como também para deposição de emergência em caso de uma eventual parada no processo por avaria ou por manutenção prolongada da instalação (TEIXEIRA, 2009).

As usinas de reciclagem e compostagem geram emprego e renda e podem reduzir a quantidade de resíduos que deverão ser dispostos no solo, em aterros sanitários. Além disto, a economia da energia que seria gasta na transformação da matéria-prima, contida no reciclado, e a transformação do material orgânico do lixo em composto orgânico adequado para nutrir o solo destinado à agricultura representam vantagens ambientais e econômicas importantes proporcionadas por estas usinas (IBAM, 2001).

\subsubsection{Incineração}

A incineração é definida como um processo de redução de massa e do volume dos resíduos (tóxicos ou não) através da combustão controlada, gerando como produto final um material inerte. 
No caso da incineração do lixo, os compostos orgânicos são reduzidos a seus constituintes minerais, principalmente dióxido de carbono, vapor d'água e sólidos inorgânicos. Os produtos da combustão são os gases, as partículas e a escória, composta de cinzas e materiais não combustíveis.

Possibilita a queima de resíduos domiciliares e patogênicos e o tratamento de resíduos perigosos, como solventes e óleos sem possibilidade de recuperação, defensivos agrícolas e produtos farmacêuticos (SAROLDI, 2005).

De acordo com EPE (2008), Usinas WTE, da sigla em inglês de waste-toenergy, são aquelas que utilizam a incineração de RSU para produzir o vapor que irá gerar energia elétrica ou será usado diretamente em processos industriais (ou para aquecimento). O processo de geração de energia elétrica pela incineração dos RSU é semelhante ao de usinas térmicas convencionais de ciclo Rankine ${ }^{2}$ e a capacidade de geração depende diretamente da eficiência da transformação do calor em energia elétrica e do poder calorífico do material incinerado. Estas podem gerar entre 450 e $700 \mathrm{kWh}$ por tonelada de RSU.

Usinas WTE trabalham tipicamente na base, isto é, a geração de energia elétrica se dá de forma permanente ao longo do dia, de modo a evitar o acúmulo de RSU no local. Contudo, diferentemente de outras usinas térmicas, o rendimento na conversão para energia elétrica é relativamente baixo, entre 20 e $25 \%$, refletindo a restrição de se operar em temperaturas muito elevadas. De fato, no atual estado da arte da tecnologia, a queima do material não deve ser feita a temperaturas superiores a $450^{\circ} \mathrm{C}$, de modo a evitar corrosão nos equipamentos. Nessas condições, uma usina WTE pode ofertar entre 450 e $600 \mathrm{kWh}$ por tonelada de RSU (EPE, 2008).

Este processo é um dos que apresenta maior custo de implantação e operação. Países ricos e com baixa disponibilidade de área, como Japão, Suíça e Suécia apresentam um grande número de incineradores.

Apesar de possuir inúmeras vantagens em relação a outras práticas para a destinação dos RSU, como a recuperação de energia, muito valorizada atualmente pelo encarecimento dos combustíveis tradicionais (CAPELINI, 2007), redução de volume entre $85 \%$ e $90 \%$ do original e produção de cimento tipo Portland a partir das cinzas produzidas (EPE, 2008), este método apresenta algumas desvantagens, conforme a seguir.

Nascimento (2007) aborda o custo elevado para instalação e operação, a exigência de mão de obra qualificada para a garantia da qualidade da operação, bem como a presença de materiais nos resíduos, que geram compostos tóxicos e corrosivos.

O relatório EPE 2008 também coloca desvantagens na utilização da incineração para a destinação de resíduos. O processo é emissor de dioxinas e cinzas que contêm diversos poluentes. Desta forma, exige 
cuidados especiais no tratamento dos gases de exaustão. Além disso, usinas de incineração apresentam elevados custos de investimento, operação e manutenção.

Tais fatores tornam tal opção pouco atrativa para países em desenvolvimento, como o Brasil.

\subsubsection{Lixões ou Vazadouros}

Lixão é uma forma inadequada de disposição final de resíduos sólidos, que se caracteriza pela simples descarga do lixo sobre o solo, sem medidas de proteção ao meio ambiente ou à saúde pública. $\mathrm{O}$ mesmo que a descarga de resíduos a céu aberto (IPT, 2000).

Esta forma de disposição facilita a proliferação de inúmeros vetores, geração de maus odores e principalmente a contaminação do solo e das águas subterrâneas e superficiais, pela infiltração dos líquidos gerados na decomposição pela RSU (NASCIMENTO, 2007).

Nos lixões vivem e trabalham inúmeras crianças, adolescentes e adultos na atividade de catação de restos de comida e de materiais passíveis de serem vendidos para o mercado de reciclagem.

Esta é a forma de disposição de resíduos mais impactante ao meio ambiente e à saúde pública (SAROLDI, 2005).

A Pesquisa Nacional de Saneamento Básico feita pelo IBGE em 2008 apontou que 2.810 cidades - mais da metade dos municípios existentes no Brasil - ainda destinavam resíduos sólidos para vazadouros a céu aberto. Quatro anos depois, ao menos 3,5 mil lixões estavam ativos, segundo estimativa da Confederação Nacional dos Municípios (CNM).

A lei 12.305, que instituiu a Política Nacional de Resíduos Sólidos (PNRS, 2010) determina a erradicação de todos os locais impróprios que se despeja lixo pelo Brasil (depósitos de lixo a céu aberto que não dispõem de sistemas de proteção ambiental adequados), com prazo de conclusão em 4 anos a partir de sua publicação (agosto de 2014).

O projeto da ABLP (Associação Brasileira de Resíduos Sólidos e Limpeza Pública, 2013) mostra que para erradicar os lixões são necessários perto de $R \$ 2$ bilhões, com a construção de 256 aterros de grande porte e 192 de pequeno porte. 


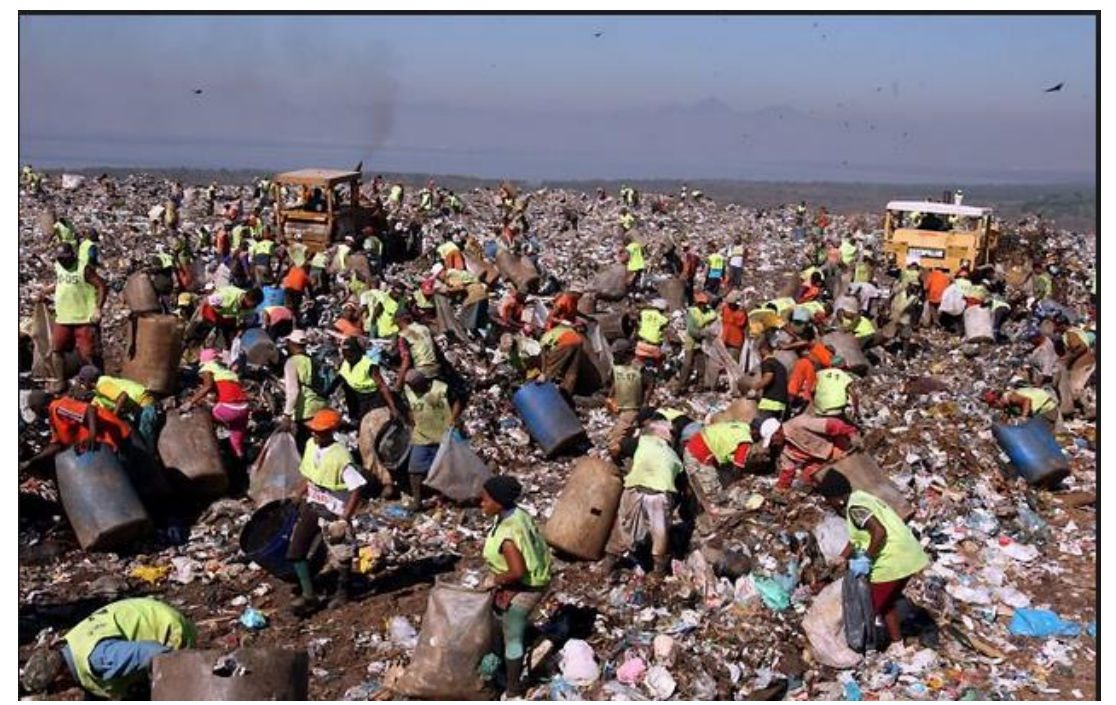

Figura 7 - Aterro de Gramacho - foto.

\subsubsection{Aterros controlados}

O aterro controlado também é uma forma de se confinar tecnicamente o lixo coletado sem poluir o ambiente externo, porém, sem promover a coleta e o tratamento do chorume e a coleta e a queima do biogás (IBAM, 2001).

Nesta técnica, não são cumpridas as exigências de um aterro sanitário, como por exemplo, a impermeabilização do solo, a coleta e tratamento de efluentes líquidos e gasosos. O lixo é depositado e compactado, seu recobrimento é feito com a maior frequência possível e em muitos casos, é previsto um sistema de drenagem de águas superficiais.

No Brasil, a existência destes aterros advém do fato de que, em muitas cidades a implantação e operação de um aterro sanitário, adotando-se seus princípios básicos, torna-se inviável técnica e economicamente, em face da escassez de recursos.

Este método deve ser utilizado como uma alternativa durante o período necessário para que a busca de soluções definitivas para a disposição dos resíduos. Alguns municípios do Estado do Rio de Janeiro dispõem seus resíduos em aterros controlados em fase de saturação e com operação ineficiente, causando danos ao meio ambiente da mesma magnitude que os danos causados pelos lixões (SAROLDI, 2005).

\subsubsection{Aterros sanitários}

De acordo com Nascimento (2007), este é um dos principais sistemas de destinação para grande parte dos resíduos produzidos no mundo.

O aterro sanitário é um método para disposição final dos resíduos sólidos urbanos, sobre terreno natural, através do seu confinamento em camadas cobertas com material inerte, geralmente solo, segundo normas 
operacionais específicas, de modo a evitar danos ao meio ambiente, em particular à saúde e à segurança pública (IBAM, 2001).

A obra de um aterro sanitário compreende um conjunto de componentes e técnicas operacionais tais como: divisão em células, compactação de resíduos, cobertura, sistema de impermeabilização do solo de fundação, sistema de coleta e drenagem de líquidos e gases, tratamento de chorume, monitoramento geotécnico e ambiental, dentre outros.

Segundo Leite (1995), a implantação de um aterro sanitário tem como principais objetivos evitar o aparecimento e proliferação de vetores, o estabelecimento de catadores na área, o espalhamento de papéis e lixo pela redondeza por ação do vento, a criação de animais que podem transmitir doenças ao Homem (porcos e aves) e a poluição de águas superficiais e subterrâneas.

Um fator cada vez mais restritivo à utilização deste processo para destinação do lixo é o custo cada vez mais elevado à sua implantação, devido ao alto preço da terra, principalmente nas regiões urbanas e industrializadas e das condicionantes impostas pelos órgãos ambientais, visando a proteção do meio ambiente (NASCIMENTO, 2007).

A PNRS (2010) institui o aterro como a última opção na hierarquia de destinação de resíduos, levando a este somente o que ainda não foi possível retornar ao Meio Ambiente.

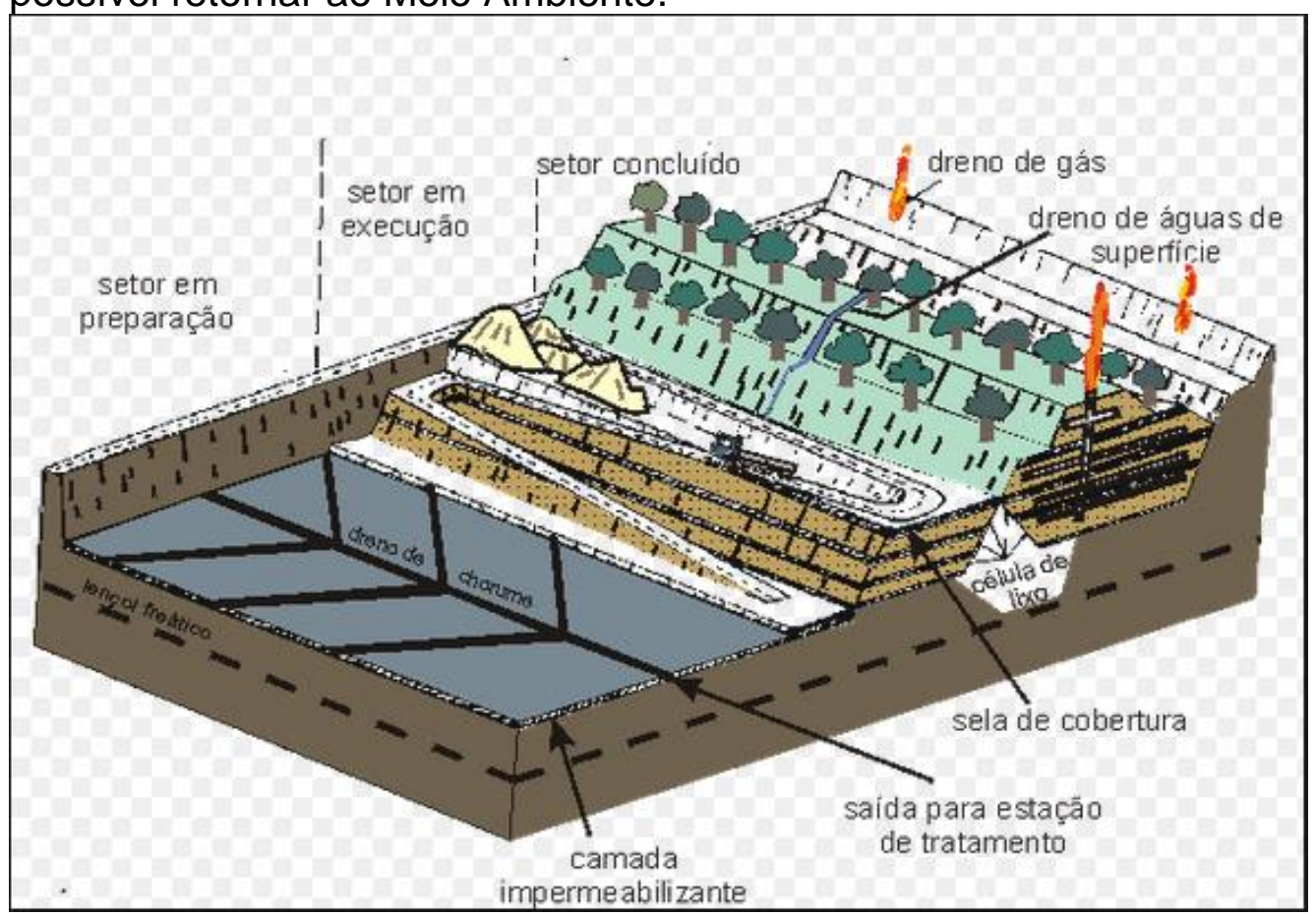

Figura 8 - Desenho esquemático de um aterro sanitário. Fonte: NASCIMENTO, 2007.

De acordo com a Pesquisa Nacional de Saneamento Básico (PNSB 2012), 27 \% das cidades descartam o lixo em aterros sanitários. 
A mesma pesquisa, há uma década, apontava que esse número era de $17 \%$. O alto custo de manutenção de um aterro sanitário é apontada pela maioria das administrações como um motivo para não manter esta opção como local para a destinação dos resíduos. Esta mesma pesquisa apontava a existência de 1.700 aterros sanitários em condições legais de funcionamento.

O relatório da EPE (2008) coloca que a tecnologia de aproveitamento do gás de lixo (GDL), ou biogás produzido nos aterros (landfill gas) é o uso energético mais simples dos RSU.

Tal técnica é uma alternativa que pode ser aplicada a curto e médio prazo para os gases produzidos na maioria dos aterros já existentes, como ocorre em centenas de aterros de diversos países. Consiste na recuperação do biogás oriundo da decomposição anaeróbica da fração orgânica de RSU, por ação de microorganismos que transformam os resíduos em substâncias mais estáveis, como dióxido de carbono $\left(\mathrm{CO}_{2}\right)$, água, metano $\left(\mathrm{CH}_{4}\right)$, gás sulfídrico $\left(\mathrm{H}_{2} \mathrm{~S}\right)$ e outros componentes.

O gás metano, principal componente do biogás, é 21 vezes mais potente que o dióxido de carbono em termos de efeito estufa. Assim, sua simples queima é um benefício ambiental direto, se comparado à sua emissão.

Além disso, o aproveitamento energético também evita a emissão decorrente da queima de combustível fóssil, que poderia ser utilizado para ofertar a mesma quantidade de energia que o biogás.

A geração do gás ocorre através de quatro fases características da vida útil de um aterro:

- Fase aeróbia: é produzido o $\mathrm{CO}_{2}$ porém é alto o conteúdo de $\mathrm{N}_{2}$, que sofre declínio nas passagens para as $2^{\underline{a}}$ e $3^{\underline{a}}$ fases.

- Esgotamento de $\mathrm{O}_{2}$ : resulta em um ambiente anaeróbio com grandes quantidades de $\mathrm{CO}_{2}$ e um pouco de $\mathrm{H}_{2}$ produzido.

- Fase anaeróbia: começa a produção de $\mathrm{CH}_{4}$, com redução na quantidade de $\mathrm{CO}_{2}$ produzido.

- Fase final: produção quase estável de $\mathrm{CH}_{4}, \mathrm{CO}_{2}$ e $\mathrm{N}_{2}$.

As condições do aterro determinam a duração das fases e o tempo de geração do gás, que podem também variar com as condições climáticas locais.

O objetivo de um projeto de aproveitamento energético de GDL é convertê-lo em alguma forma de energia útil, como eletricidade, vapor, combustível para caldeiras ou fogões, combustível veicular ou, ainda, para abastecer gasodutos com gás de qualidade.

O biogás coletado e filtrado pode também ser utilizado para a geração de eletricidade, em geral alimentando grupos motor-gerador de combustão 
interna de pequena potência, adequados à queima de gás pobre. Mesmo alimentados com combustível de baixo poder calorífico, o rendimento desses geradores pode superar $35 \%$.

O dimensionamento de usinas para o aproveitamento do gás coletado em aterro sanitário para geração de energia elétrica não é trivial e, mais do que outras fontes, encerra forte compromisso técnico-econômico em razão da curva declinante de oferta da energia primária.

Diferentemente dos processos de geração de energia através da digestão anaeróbica e da incineração, o aproveitamento do gás de aterro não traz redução significativa do volume de lixo acumulado, de modo que a deposição contínua de resíduos acaba por esgotar a capacidade de acumulação do aterro sanitário.

Ao longo do tempo de acumulação do lixo a produção de biogás é crescente, porém, uma vez cessada a deposição, a produção entra em declínio mais ou menos acentuado dependendo da composição do lixo depositado. Esse comportamento da oferta do combustível é ilustrado na Figura 9.

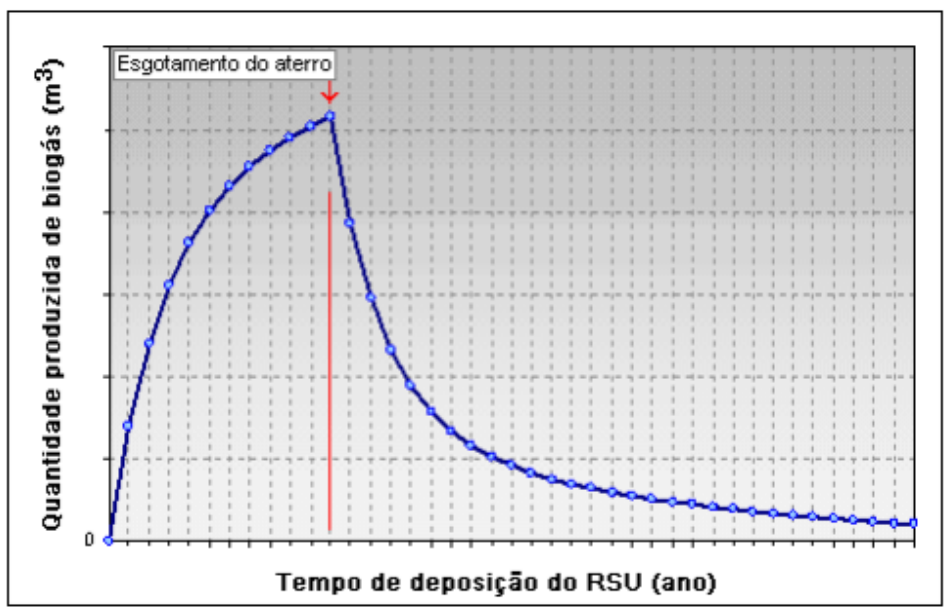

Figura 9 - Evolução típica da produção de biogás em aterro sanitário.

O aproveitamento econômico do gás para a geração de energia elétrica fica limitado a um espaço de tempo relativamente pequeno (entre 12 e 18 anos) em relação ao tempo de duração das emissões.

Mesmo durante este tempo, nem todo o gás produzido é aproveitável para a geração em razão de limitação econômica da potência das unidades geradoras.

É necessário salientar que a queima do gás do lixo em grupos motorgerador não elimina a necessidade de filtragem dos gases de exaustão para a redução da emissão de poluentes, nem a instalação de flares para queima simples do gás excedente. 
Existe ainda a possibilidade de cogeração de eletricidade e energia térmica a partir do GDL como alternativa mais eficiente em termos energéticos. A energia térmica pode ser usada localmente para aquecimento, refrigeração e outras necessidades do processo industrial.

\subsubsection{Reciclagem de resíduos secos}

A reciclagem de resíduos secos, alternativa para a destinação de RSU que apresenta inúmeras vantagens frente sua deposição em aterro sanitário conforme será detalhado nos próximos parágrafos deste capítulo, está diretamente ligada ao tema de estudo desta pesquisa, já que um dos objetivos do Tratamento Mecânico e Biológico (TMB) é aumentar o volume de itens recicláveis na separação mecânica.

De acordo com IBAM (2001), denomina-se reciclagem a separação de materiais do lixo domiciliar, tais como papéis, plásticos, vidros e metais, com a finalidade de trazê-los transformados em produtos comercializáveis ao mercado de consumo.

A Política Nacional de Resíduos Sólidos (2010) abrange também os resíduos orgânicos e define reciclagem como:

[...] processo de transformação dos resíduos sólidos que envolve a alteração de suas propriedades físicas, físico-químicas ou biológicas, com vistas à transformação em insumos ou novos produtos, observadas as condições e os padrões estabelecidos pelos órgãos competentes do Sisnama e, se couber, do SNVS e do Suasa."

Os principais benefícios ambientais da reciclagem dos materiais secos existentes no lixo são a economia de matérias-primas não-renováveis, a economia de energia nos processos produtivos e o aumento da vida útil dos aterros sanitários.

Tais benefícios se estendem também aos campos econômico e social, já que a energia e matéria prima são fatores representativos na estrutura de custo das indústrias. Além disso, a crescente demanda pela reciclagem de resíduos gerou um novo mercado, com novas empresas e serviços e consequentemente novos empregos.

No campo econômico, um exemplo emblemático é o alumínio. O metal das latas utilizadas como embalagem de sucos, refrigerantes e cervejas não perde suas propriedades físicas quando reprocessado e assim pode ser, na prática, reprocessado continuamente.

Sua viabilidade econômica é claramente demonstrada, pois $1 \mathrm{~kg}$ de alumínio reciclado evita a extração de $5 \mathrm{~kg}$ de bauxita e a mineração e transformação do mineral requerem para produção do alumínio primário, eletricidade em quantidade 20 vezes maior que a demandada na produção a partir do material reciclado (EPE, 2008). 
No campo social, a reciclagem tem sido apontada frequentemente como atividade geradora de emprego e renda, em especial para as classes de poder aquisitivo mais baixo, conforme a própria PNRS (2010) prevê.

Além das classes de renda mais baixa, há também potencial de geração de emprego técnico, principalmente no segmento de plásticos e papéis. A sociedade apresenta ganhos com a geração de novos negócios, bem como a geração de empregos diretos e indiretos (IPT, 2000).

O Brasil tem apresentado ganhos significativos, exatamente pelo perfil da atividade de catação e a má distribuição de renda do país. Atribui-se a este fato o elevado índice nacional de reciclagem de latas de alumínio e garrafas PET, superior a vários países onde a preocupação com a reciclagem e com os impactos ambientais estão num estágio muito mais avançado do que no Brasil, como países da UE.

De acordo com a Associação Brasileira de Alumínio (ABAL), o Brasil reciclou, em 2006, 138,1 mil toneladas de sucata de latas, o que corresponde a 10,3 bilhões de unidades. Pelo sexto ano consecutivo, o país liderou a reciclagem de latas de alumínio para bebidas, com índice de $94,4 \%$, superior ao do Japão (90,9\%) e Argentina (89,6\%).

Nesse mesmo ano, conforme dados da organização Compromisso Empresarial para Reciclagem (CEMPRE), 51,3\% das embalagens PET pós-consumo foram efetivamente recicladas no país, totalizando 194 mil toneladas.

O índice brasileiro de reciclagem de embalagens PET é bastante superior ao de países como a Alemanha, que apresenta índice de $32 \%$. A Tabela 3 apresenta alguns dados que evidenciam a posição de destaque que 0 Brasil ocupa no mundo, quando se trata de reciclagem de PET e de latas de alumínio.

\begin{tabular}{lcc}
\hline Pais/região & Latas & PET \\
\hline BRASIL & $94,4 \%$ & $51,3 \%$ \\
Japão & $90,9 \%$ & $62,0 \%$ \\
Argentina & $89,6 \%$ & $27,1 \%$ \\
Europa & $57,7 \%$ & $38,6 \%$ \\
Estados Unidos & $51,6 \%$ & $23,5 \%$ \\
\hline
\end{tabular}

Tabela 3 - Índices de reciclagem de embalagens PET e latas de alumínio. Fonte: Cempre, 2013.

Além de consequências ambientais econômicas e sociais, o mercado de reciclagem gera também maior consciência ambiental e dos princípios de cidadania por parte da população.

Outro fator que merece análise detalhada é a conservação de energia a partir da reciclagem. 
Conforme salientado, a reciclagem contribui para reduzir a demanda por fontes naturais de matéria-prima, muitas vezes não renováveis e também a demanda por energia, necessária para a transformação dessa matéria prima em produtos destinados ao uso final.

A estimativa da energia elétrica conservada a partir do uso de material reciclável como matéria prima requer a definição de fatores de conversão, geralmente expressos em $\mathrm{MWh} / \mathrm{t}$ ou $\mathrm{kWh} / \mathrm{kg}$, em cuja determinação podem ser utilizadas diferentes critérios e abordagens metodológicas.

A Nota Técnica DEN 06/08 (EPE, 2008) avaliou algumas metodologias, gerando a Tabela 3 a seguir.

Considerando, por exemplo, o indicador de Calderoni para a reciclagem de alumínio no Brasil $(5,30 \mathrm{kWh} / \mathrm{kg})$, calcula-se que o potencial de energia elétrica conservada com a reciclagem do alumínio (isto é, se todo o alumínio contido no RSU gerado no país fosse destinado à reciclagem) é de $20.500 \mathrm{MWh} /$ dia, ou o equivalente à geração média de uma usina hidrelétrica de $1.400 \mathrm{MW}$ de potência instalada ou de uma usina termelétrica convencional com $1.050 \mathrm{MW}$, operando com $80 \%$ de capacidade.

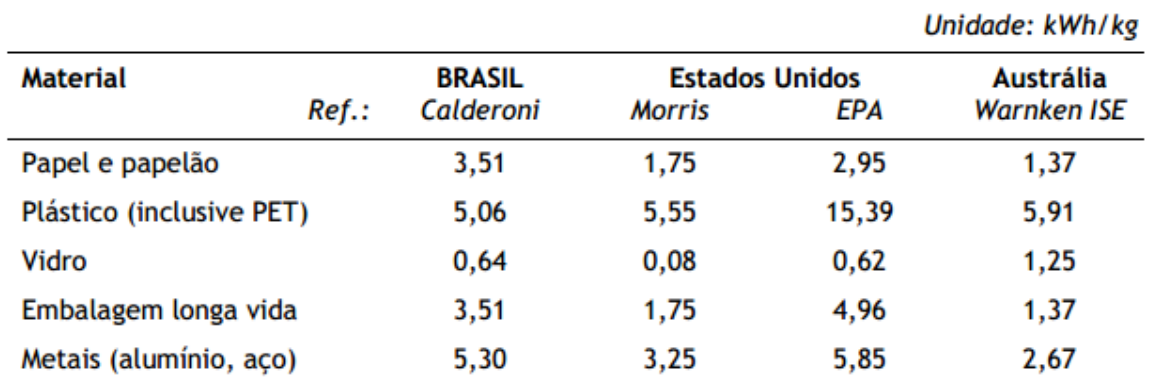

Tabela 4 - Potencial de conservação de energia elétrica a partir da reciclagem de embalagens.

Fonte: EPE, 2008.

O mesmo cálculo reproduzido com o indicador apurado no relatório do Warnken ISE, leva à potência hidrelétrica equivalente de $720 \mathrm{MW}$ e termelétrica de $540 \mathrm{MW}$.

Para um índice médio de $1,1 \mathrm{kWh} / \mathrm{kg}$ de RSU, considerando que a quantidade gerada no país em 2007 foi de 168,7 mil toneladas por dia, estima-se que o potencial de conservação de energia elétrica contido na reciclagem de RSU seja de 185 mil MWh por dia, ou $7.700 \mathrm{MWmed,} \mathrm{o}$ equivalente à potência instalada de $14.000 \mathrm{MW}$ em usinas hidrelétricas ou de $9.600 \mathrm{MW}$ em termelétricas convencionais, operando com $80 \%$ de sua capacidade.

Considerando o crescimento demográfico, a evolução da taxa de urbanização e índice de coleta apresentado na Note Técnica DEN 13/14 (EPE, 2014), este mesmo cálculo reproduzido para o ano de 2030 indicaria um potencial equivalente a uma potência hidrelétrica de cerca de 


\subsection{MW.}

Ressalta-se, entretanto, que boa parte desse potencial de conservação de energia elétrica, decorrente da reciclagem do alumínio, é hoje alcançado devido ao alto índice de reciclagem do alumínio do país.

O grande desafio para implantação dos programas de reciclagem é a busca de um modelo que permita a sua sustentabilidade econômica.

O modelo planejado pela PNRS (2010) baseia-se principalmente na coleta seletiva para a obtenção dos resíduos recicláveis, apresentando algumas dificuldades, que serão abordadas detalhadamente a seguir.

Devido à importância da reciclagem na destinação de resíduos brasileiros e seu direto envolvimento com a tecnologia deste estudo, os próximos capítulos abordarão detalhadamente o processo de reciclagem de plásticos, a reciclagem de papéis como também a produção do CDR, combustível derivado de resíduos.

\begin{tabular}{|c|c|c|}
\hline RESÍDUOS & PARTICIPAÇÃO & $\begin{array}{l}\text { QUANTIDADE } \\
\text { (ton/dia) }\end{array}$ \\
\hline Material reciclável & $31,9 \%$ & $58.527,40$ \\
\hline Metais & $2,9 \%$ & $5.293,50$ \\
\hline Aço & $2,3 \%$ & $4.213,70$ \\
\hline Alumínio & $0,6 \%$ & $1.079,90$ \\
\hline Papel, papelão, tetra pak & $13,1 \%$ & $23.997,40$ \\
\hline Plastico total & $13,5 \%$ & $24.847,90$ \\
\hline Plastico filme & $8,9 \%$ & $16.399,60$ \\
\hline Plastico rígido & $4,6 \%$ & $8.448,30$ \\
\hline Vidro & $2,4 \%$ & $4.388,60$ \\
\hline matéria orgânica & $51,4 \%$ & $94.335,10$ \\
\hline outros & $16,7 \%$ & $30.618,90$ \\
\hline Total & $100,0 \%$ & $183.481,50$ \\
\hline
\end{tabular}

Tabela 4 - Composição gravimétrica dos RSU coletados no Brasil em 2008.

Fonte: Plano Nacional de Resíduos Sólidos, 2011.

Conforme demonstra a Tabela 4, o papel e plástico são os componentes de maior representatividade na composição gravimétrica da parte seca dos resíduos brasileiros. Desta forma, apresentam maior potencial de mercado a ser desenvolvido.

\subsubsection{Processo de reciclagem do plástico}

Um questionamento relevante no contexto da sustentabilidade diz respeito à análise de processos para a destinação de resíduos plásticos, comparando-se a incineração com recuperação energética, a reciclagem mecânica ou a reciclagem química.

MORRIS (1996) apud CAPELLINI (2007) realizou a análise de conservação de energia das diferentes técnicas e verificou que a reciclagem mecânica apresenta maior economia de energia do que a 
produzida na incineração de resíduos sólidos urbanos em 24 de 25 resíduos.

Tal fato ocorre porque o aquecimento do RSU consome aproximadamente $15 \%$ da energia intrínseca disponibilizada pela queima dos materiais. Portanto, sob esse ponto de vista, é muito difícil recomendar a técnica de reciclagem energética como uma solução apropriada para os resíduos plásticos pós-consumo (OLIVEIRA, 2012).

Reciclagem primária, ou re-extrusão

Também chamada de reciclagem pré-consumo (ROLIM, 2000 apud CAPELLINI (2007)), é a reintrodução de sucatas e fragmentos de polímeros no ciclo para a produção de produtos de materiais similares. São utilizados plásticos com características semelhantes aos produtos originais.

Reciclagem secundária, ou mecânica

É o reprocessamento de materiais poliméricos simples (formados por somente um tipo de resina) utilizando meios mecânicos (AL-SALEM, LETTIERI e BAEYENS, 2010 apud CAPELLINI (2007)), conforme demostra a Figura 10.

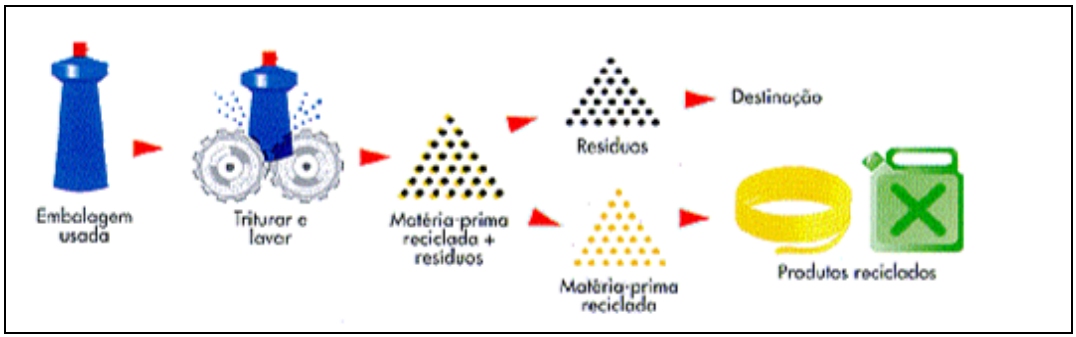

Figura 10 - Fluxo das etapas da reciclagem mecânica.

Fonte: Plastvida, 2009.

\section{Reciclagem terciária ou química}

Consiste na reciclagem de produtos químicos ou de matéria prima, envolvendo processos de despolimerização (OLIVEIRA, 2012).

A BRITISH PLASTICS FEDERATION (2011) apud CAPELLINI (2007) considera a reciclagem química e a de matéria prima como duas categorias diferentes. Tal diferença reside na utilização do produto final.

$\mathrm{Na}$ reciclagem de matéria-prima, a estrutura química do material residual é alterada, de modo que os produtos químicos resultantes podem ser usados para outros fins que não a produção do material original. $\mathrm{Na}$ reciclagem química, o produto resultante só é utilizado para produzir o material original. 


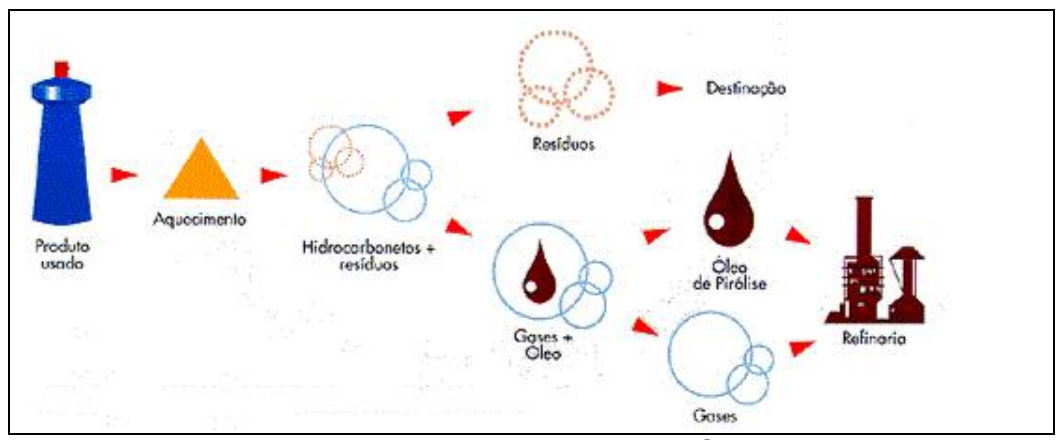

Figura 11 - Fluxo das etapas da reciclagem química. Fonte: Plastivida, 2009.

Reciclagem quaternária, ou recuperação energética de resíduos

É um método de reciclagem que tem crescido muito nos últimos anos.

A queima dos resíduos para gerar calor, vapor ou energia tem representado de modo crescente uma alternativa, seja para a destinação dos resíduos urbanos como um todo, seja para os resíduos de plásticos.

Estima-se que a incineração de resíduos plásticos proporcione uma redução de 90 a $99 \%$ em volume, diminuindo assim o descarte em aterros. No processo de recuperação de energia, a destruição de espumas e grânulos também destrói CFCs e outros agentes nocivos (OLIVEIRA, 2012).

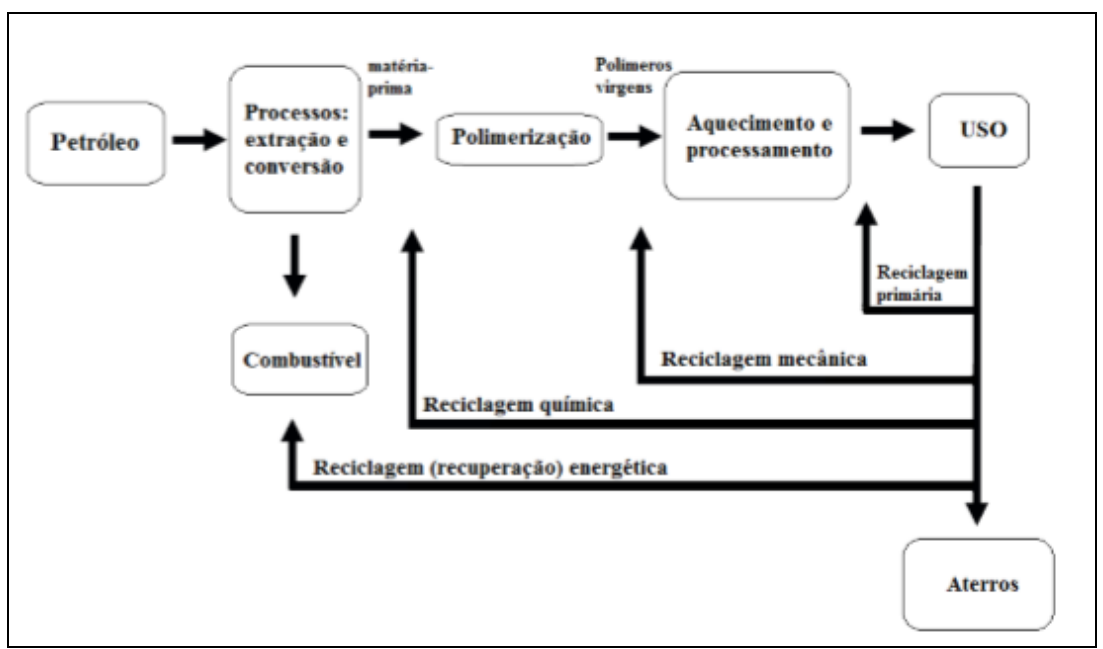

Figura 12 - Produção e todas de destinação de plásticos.

Fonte: Oliveira, 2012.

O método mais utilizado é o da reciclagem mecânica, porém só pode ser realizado em produtos que contenham apenas um tipo de resina. Desta forma, quanto mais misturado e contaminado for o resíduo, mais difícil será reciclá-lo mecanicamente, por isso a necessidade de separação do material plástico em fase anterior à da reciclagem (OLIVEIRA, 2012).

A reciclagem mecânica, em escala industrial em geral envolve uma série de tratamentos e etapas de preparação, conforme a seguir.

- Separação manual: triagem de acordo com o aspecto visual ou com a identificação dos diferentes tipos de plásticos. Como é uma 
tarefa essencialmente manual, depende da competência e constante atenção das pessoas envolvidas;

- Moagem: envolve a redução do tamanho do material, transformando-o em fragmentos menores, como grânulos, pó ou flocos;

- Lavagem: lavagem do material com água para retirada dos contaminantes, com posterior tratamento para sua possível reutilização ou descarte como efluente;

- Aglutinação: depois de lavado e seco, o material plástico é compactado em um aglutinador, para que o volume enviado ao processador final, normalmente uma extrusora, seja reduzido.

Forma-se então uma massa plástica a partir do atrito dos fragmentos plásticos com as paredes do equipamento, devido a uma elevação da temperatura do conjunto;

- Processamento: a última etapa do processo é a que forma os pellets (grãos plásticos) que serão enviados às indústrias transformadoras.

A massa plástica é fundida e homogeneizada na extrusora. $\mathrm{Na}$ saída do processo, encontra-se um cabeçote do qual saem filamentos contínuos, então resfriados em água. Em seguida, um granulador picota os filamentos, formando os pellets.

A princípio, todos os plásticos podem ser submetidos à reciclagem mecânica, porém a seleção dos que realmente serão reciclados dependerá do seu valor econômico e do volume de material disponível (OLIVEIRA, 2012).

\subsubsection{Processo de reciclagem do papel}

De acordo com a Bracelpa (Associação Brasileira de Papel e Celulose), o Brasil apresenta o índice de reciclagem de 45,5\% (2011), ou seja, em 2011 o consumo aparente de papel no País registrou 9,6 milhões de toneladas e a recuperação de aparas foi de 4,4 milhões de toneladas.

No que diz respeito ao processo de reciclagem do papel, este conta com mais um agente da cadeia: os aparistas, também conhecidos como atravessadores, termo mais utilizado no mercado de coleta e reciclagem de resíduos.

De acordo com a ANAP (Associação Nacional de Aparistas de Papel), existem aproximadamente 1.000 aparistas no país (ANAP, 2012), que armazenam, separam e classificam as aparas de papel comercializadas com catadores, ONG's e demais organizações para posterior venda aos fabricantes. 
Após chegada aos fabricantes, os fardos de papel são misturados à água em um equipamento chamado hidrapulper - uma espécie de grande liquidificador -, formando a pasta de celulose. Em seguida, esta passa por uma peneira para que sejam retiradas impurezas, como pedaços de papel não desejáveis, fitas adesivas, plástico, arames e outros metais.

$\mathrm{Na}$ etapa seguinte, são aplicados compostos químicos (água e soda cáustica) para a retirada de tintas. Uma depuração mais fina separa a areia.

Posteriormente, em outros equipamentos - chamados refinadores -, a pasta é processada para que as fibras que formam a celulose se abram um pouco mais, melhorando a ligação entre elas, o que garante mais resistência. Finalmente a pasta é branqueada e segue para os equipamentos, comumente utilizados para a fabricação do papel.

Conforme sua utilidade final, o papel reciclado recebe diferentes tratamentos que permitem melhor absorção de tinta na impressão, bem como textura, resistência e cor adequada.

No caso de embalagens, o papel é refinado e associado a outros materiais para ter mais resistência. A superfície externa de caixas de papelão é feita com fibras virgens, mais fortes. As fibras recicladas são mais empregadas no forro e miolo que compõem a camada interior do papelão (ANAP, 2014).

O fluxo do processo pode ser descrito conforme a Figura 13.

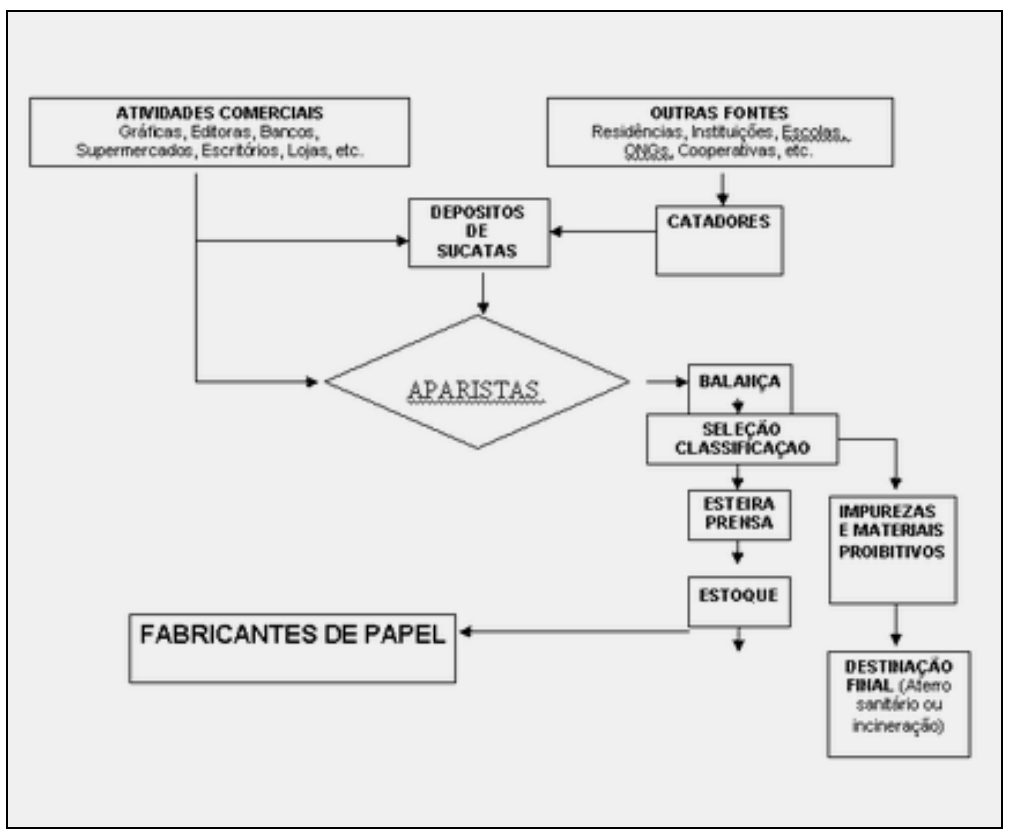

Figura 13 - Fluxo do processo de reciclagem de papel.

Fonte: ANAP, 2014. 


\subsubsection{Combustível Derivado de Resíduos (CDR)}

Outra forma de reciclagem de resíduos secos é a produção do CDR, uma aglutinação de resíduos com alto poder calorífico para a geração de energia.

De acordo com Mamede (2013), o CDR é produzido pela seleção mecânica da fração combustível do resíduo sólido. Sua produção pode ser parte do sistema de tratamento térmico, como também um dos produtos do Tratamento Mecânico e Biológico de Resíduos (TMB), tecnologia foco deste estudo, que será detalhado no próximo capítulo.

Sua utilização acarreta inúmeros benefícios, dentre os quais se destaca o elevado poder calorífico, a homogeneidade da composição físico-química, o fácil armazenamento, manipulação e transporte, a baixa emissão de poluentes e a reduzida necessidade de excesso de ar durante a combustão.

Entretanto, a produção de CDR com elevado poder calorífico necessita de uma complexa linha de produção, conduzindo à baixa eficiência mássica, gerando significante quantidade de rejeitos. A busca pelo elevado poder calorífico inferior leva à maior quantidade de fases no processo e menor massa final de CDR.

Tal fato conduz a custos mais elevados de produção, os quais reduzem o apelo de mercado do produto. Tipicamente, cerca de $30 \%$ da massa de entrada é convertida em CDR densidificado, peletizado (MAMEDE, 2013).

Com relação ao potencial energético, o RSU apresenta tipicamente teor energético de $9-11 \mathrm{MJ} / \mathrm{kg}$, enquanto o CDR pode apresentar $17 \mathrm{MJ} / \mathrm{kg}$ (ENVIROS, 2007).

Uma linha de produção de CDR consiste em inúmeros processos ordenados em série, com o objetivo de separar componentes indesejados e condicionar o material, a fim de obter combustível com características pré-determinadas. Isto é realizado por meio de sucessivos estágios de tratamento como peneiramento, trituração, redução de tamanho, classificação, separação, secagem e densidificação.

O tipo, número e posição dos equipamentos de processo ao longo da linha de produção afetam largamente o balanço de massa e a qualidade do produto final.

Há dois processos básicos de CDR, cada um produzindo um produto distinto, conhecido como CDR densidificado (Tipo A) e CDR grosseiro (Tipo B).

O CDR densidificado é produzido como peletes. Antes de ser peletizado é seco, de modo a ficar relativamente estável e poder ser transportado, manuseado e armazenado como qualquer outro combustível sólido. Ele 
pode ser queimado em unidades dedicadas, ou utilizado em cocombustão com carvão e outros combustíveis sólidos.

O CDR densidificado requer considerável processamento, incluindo secagem e peletização, e também requer elevada quantidade de energia no processo. O consumo de energia global para o processo de CDR densidificado tem sido estimado para $55,5 \mathrm{kWh}$ por tonelada de RSU que entra na planta. $O$ processo de secagem anterior à peletização requer cerca de $400 \mathrm{MJ}$ de calor por tonelada.

O CDR grosseiro requer menos processamento, mas como não é seco, não pode ser armazenado por um longo período. Ele é apropriado para uso local na geração de eletricidade e/ou calor (MAMEDE, 2013).

De modo geral, o processo básico de produção do CDR pode ser dividido em cinco estágios distintos, descritos a seguir: recepção e armazenamento; liberação e triagem; refinamento do combustível; preparação e combustível e armazenamento e controle de qualidade.

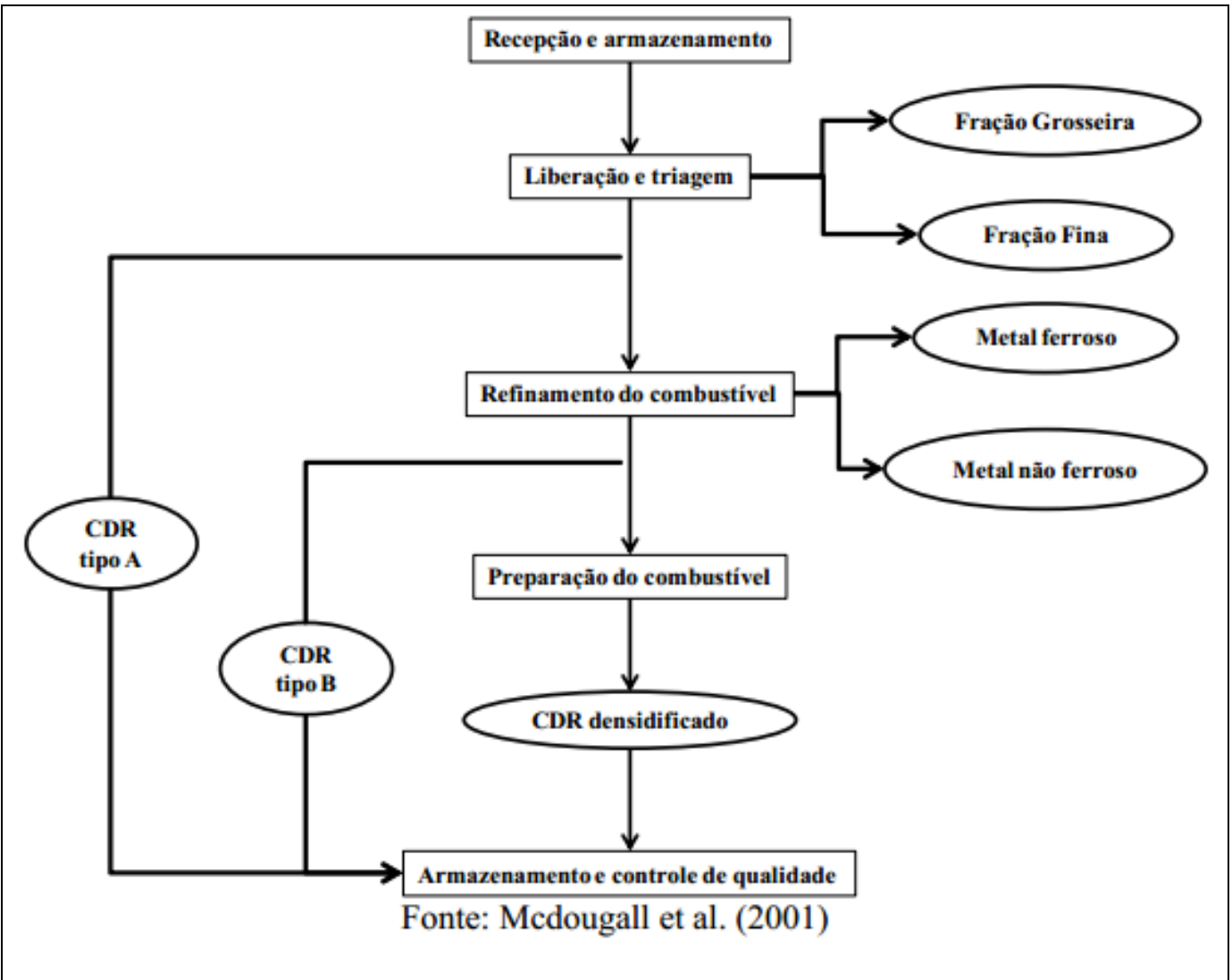

Figura 14 - Processo de produção de CDR.

Fonte: Mamede, 2013.

A etapa de refinamento do combustível envolve redução de tamanho de partícula, classificação e separação magnética. A redução de tamanho usualmente é feita por triturador ou moinho. A separação por densidade (classificação) é necessária para separar a fração pesada (metal, plástico 
denso) da fração combustível leve (plástico filme, papel), a qual irá formar o CDR densidificado.

O estágio de preparação do combustível representa a grande diferença entre o CDR grosseiro e o densidificado.

Uma trituração secundária é necessária para reduzir o tamanho de partícula necessário na operação de peletização e a secagem reduz o teor de umidade de $30 \%$ para $12 \%$ aproximadamente.

Após este estágio o CDR densidificado pode ser produzido com um teor final de cinzas de $10 \%$ em peso. O CDR densidificado pode tomar forma de pelete ou briquete. Os moinhos de pelete são energo-intensivos, consumindo mais de $35 \mathrm{kWh}$ por tonelada de combustível produzido, de modo que este precisa ser resfriado antes do armazenamento, para remoção do calor produzido na compressão.

Estes equipamentos são suscetíveis a sofrer danos com contaminação de partículas densas, de modo que equipamentos utilizados no TMB, como de separação magnética e separador balístico são frequentemente utilizados para remoção de metais ferrosos e outros materiais densos.

Uma vez secos e na forma de pelete, o CDR densidificado pode ser armazenado. Em contrapartida, o CDR grosseiro necessita ser queimado dentro de pouco tempo após sua produção (MAMEDE, 2013).

\begin{tabular}{|c|c|c|c|c|}
\hline COMBUSTIVEL & UNIDADE & $\begin{array}{c}\text { FATOR } \\
\text { EMISSÃO } \\
\mathrm{CO}_{2}\end{array}$ & $\begin{array}{c}\text { PODER } \\
\text { CALORIFICO } \\
\text { INFERIOR } \\
(\mathrm{Mj} / \mathrm{kg}) \\
\end{array}$ & $\begin{array}{c}\mathrm{CO}_{2} \text { POR } \\
\text { UNIDADE } \\
\text { ENERGÉTICA }\end{array}$ \\
\hline Óleo & ton & 78,8 & 40,5 & 1,95 \\
\hline $\begin{array}{l}\text { Coque de } \\
\text { Petróleo }\end{array}$ & ton & 97 & 33,5 & 2,9 \\
\hline Carvão & ton & 98,3 & 33,5 & 2,93 \\
\hline $\begin{array}{c}\text { Gás metano (de } \\
\text { aterro) }\end{array}$ & $1.000 \mathrm{~m}^{3}$ & 56,1 & 17 & 3,3 \\
\hline CDR & ton & 31,8 & 20 & 1,59 \\
\hline
\end{tabular}

Tabela 5 - Comparativo de emissões de $\mathrm{CO}_{2}$

Fonte: Estre Ambiental, Congresso Waste to Energy, 2014 apud MAMEDE, 2013.

\subsection{Coleta Seletiva}

A coleta seletiva é o modelo mais empregado nos programas de reciclagem e consiste na separação, pela população, dos materiais recicláveis existentes nos resíduos domésticos para que posteriormente os mesmos sejam coletados por um veículo específico.

A separação pode ser feita por tipo de materiais (papel, papelão, plástico, metais e vidro) ou somente a separação entre o lixo úmido (matéria orgânica) a ser coletada no veículo regular e o lixo reciclável, a ser coletado em veículo específico. O mais comum nos municípios brasileiros que possuem uma coleta seletiva organizada porta a porta é o segundo modo citado (CAPELINI, 2007). 
Uma opção complementar à coleta seletiva, que visa maior acúmulo de resíduos para posterior coleta do veículo específico é o Ponto de Entrega Voluntária (PEV).

Consiste na instalação de contêineres ou recipientes em locais públicos para que a população, voluntariamente, possa fazer o descarte dos materiais separados em suas residências.

A Resolução CONAMA nำ 275, de 25/4/2001 estabelece o código de cores para os diferentes tipos de resíduos, a ser adotado na identificação de coletores e transportadores, bem como nas campanhas informativas para a coleta seletiva (IBAM, 2001).

Visando a simplificação do processo e consequentes ganhos imediatos, a Resolução CONEMA no 55 de 13/12/2013 reduz o número de cores para 2 (dois) - recicláveis e rejeitos ou para 3 (três), incluindo os compostáveis.

Após a implantação da coleta seletiva, o poder público deve manter a população permanentemente mobilizada através de campanhas de sensibilização e de educação ambiental.

Capelini (2007) apresenta alguns dos benefícios da coleta seletiva, descritos a seguir.

- Melhor qualidade dos materiais recuperados, devido à separação no local da coleta, sem mistura com itens orgânicos;

- Estímulo à cidadania, devido à necessidade de participação comunitária;

- Pode ser iniciada em pequena escala e ampliada gradualmente;

- Permite articulações com catadores, associações ecológicas e empresas;

- Reduz o volume de lixo a ser disposto, caso os resíduos gerados nesta coleta seja utilizados em processo de reciclagem/reuso.

Por outro lado, segundo os mesmos autores, há um grande aumento de custo, quando comparada à coleta regular, já que há necessidade de esquemas especiais de coleta, aumentando consideravelmente o custo de frete, como também de centros de triagem.

O último relatório do Cempre (2013) mostra que o custo com a coleta seletiva é 4,5 vezes maior que o relacionado à coleta domiciliar, que será detalhado no capítulo seguinte deste estudo.

Embora, como mencionado por Vilhena e D' Almeida (2000), haja um estímulo à cidadania, esta participação necessária da comunidade pode não ser tão simples. Há a necessidade de investimentos constantes na divulgação e esclarecimento da população.

Outro problema que os programas de coleta seletiva enfrentam é a mudança nas gestões municipais. É muito comum o abandono ou a 
diminuição de investimento nos programas devido a interesses políticos de diferentes grupos.

Não se pode deixar de citar também a presença de catadores não organizados nas cidades brasileiras e sua consequência para o sucesso da coleta seletiva. Estes fazem catação dos materiais diretamente nas ruas, separando os materiais com melhor valor comercial, anteriormente à realização da coleta realizada por órgãos credenciados, reduzindo assim a viabilidade do negócio que também envolve catadores, porém estes organizados em cooperativas, conforme previsto na PNRS (2010).

É importante salientar que a PNRS (2010) incentiva a coleta seletiva e os demais desdobramentos em metas estaduais e municipais devem envolver esta ação. Mesmo com metas determinadas e investimentos definidos, os resultados ainda são muito baixos, conforme será detalhado no capítulo 4 deste estudo.

\subsection{Legislação Brasileira}

O tema meio ambiente vinha sendo discutido desde 1981, com sua primeira Política Nacional, sofrendo evoluções ao longo dos anos, conforme Tabela 6 , que apresenta as mudanças em ordem cronológica.

Segundo o Decreto no 7.404, de 23 de dezembro de 2010, que regulamentou a Lei $12.305 / 10$, a política "articula-se com as diretrizes nacionais para o saneamento básico e com a Política Federal de Saneamento Básico, nos termos da Lei no 11.445, de 5 de janeiro de 2007, com a Lei no 11.107, de 6 de abril de 2005 (normas gerais de contratação de consórcios públicos), e com a Política Nacional de Educação Ambiental, regulada pela Lei no 9.795, de 27 de abril de 1999."

Tal publicação foi um marco no mercado, modificando o processo de Gestão de Resíduos Sólidos, tanto no âmbito público, como empresarial.

As ações previstas na nova lei têm o potencial de diminuir drasticamente os gases do efeito estufa. De acordo com estudo do Centro de Tecnologia de Embalagem - Cetea de Campinas (CETEA, 2010 apud Decreto no 7.404 ), o corte de carbono emitido pelo lixo brasileiro poderá atingir $74 \%$.

A Política é dividida em 4 (quatro) Títulos: disposições gerais, a política nacional de resíduos sólidos, diretrizes aplicáveis aos resíduos sólidos e disposições finais e transitórias.

Disposições Gerais - são apresentados os princípios, objetivos e instrumentos dessa Política, visando o gerenciamento e gestão integrada dos resíduos sólidos. Neste ponto, destaca a responsabilidade dos geradores e poder público.

No art. 3, a Política trata de termos importantes e antes não abordados de forma clara, como a reutilização, reciclagem, coleta seletiva, controle 
social, ciclo de vida do produto, destinação e disposição final, a gestão integrada de resíduos sólidos, como também os padrões sustentáveis de produção e consumo.

Política Nacional de Resíduos Sólidos - Neste Título, o documento aborda os princípios e objetivos, definidos com visão ambiental, sem deixar de lado as considerações econômicas, necessárias para o desenvolvimento de qualquer sociedade.

A Política apresenta 11 (onze) Princípios, 6 (seis) destes diretamente ligados aos temas abordados nesta dissertação:

[...] "III - a visão sistêmica, na gestão dos resíduos sólidos, que considere as variáveis ambiental, social, cultural, econômica, tecnológica e de saúde pública;"

[...] "V - a ecoeficiência, mediante a compatibilização entre o fornecimento, a preços competitivos, de bens e serviços qualificados que satisfaçam as necessidades humanas e tragam qualidade de vida e a redução do impacto ambiental e do consumo de recursos naturais a um nível, no mínimo, equivalente à capacidade de sustentação estimada do planeta;

VI - a cooperação entre as diferentes esferas do poder público, o setor empresarial e demais segmentos da sociedade;

VIII - o reconhecimento do resíduo sólido reutilizável e reciclável como um bem econômico e de valor social, gerador de trabalho e renda e promotor de cidadania [...]";

[...] "IX - o respeito às diversidades locais e regionais;

$\mathrm{X}$ - $\mathrm{O}$ direito da sociedade à informação e ao controle social[...] “;

Apresenta também 15 (quinze) Objetivos, 11 (onze) diretamente ligados aos temas abordados nesta dissertação. Inclusive os itens IV, V e XIV têm ligação direta com a tecnologia em estudo: o Tratamento Mecânico e Biológico de resíduos sólidos.

[...] "II - não geração, redução, reutilização, reciclagem e tratamento dos resíduos sólidos, bem como disposição final ambientalmente adequada dos rejeitos" [...];

[...] "IV - adoção, desenvolvimento e aprimoramento de tecnologias limpas como forma de minimizar impactos ambientais;

V - redução do volume e da periculosidade dos resíduos perigosos;

$\mathrm{VI}$ - incentivo à indústria da reciclagem, tendo em vista fomentar o uso de matérias-primas e insumos derivados de materiais recicláveis e reciclados;

VII - gestão integrada de resíduos sólidos;

VIII - articulação entre as diferentes esferas do poder público, e destas com o setor empresarial, com vistas à cooperação técnica e financeira para a gestão integrada de resíduos sólidos;

IX - capacitação técnica continuada na área de resíduos sólidos; 


\begin{tabular}{|c|c|c|}
\hline TÍTULO & DATA & OBSERVAÇÖES \\
\hline $\begin{array}{l}\text { Lei } n^{\circ} 6.938 \text { - Política Nacional do } \\
\text { Meio Ambiente }\end{array}$ & $\begin{array}{c}31 \text { de agosto } \\
\text { de } 1981\end{array}$ & $\begin{array}{l}\begin{array}{l}\text { Primeira legislação a dispor sobre preservação ambiental e conservação } \\
\text { de recursos naturais no país. Não abordava a disposição de resíduos ou } \\
\text { reciclagem. }\end{array} \\
\end{array}$ \\
\hline Projeto de Lei 203 & 1991 & $\begin{array}{c}\text { Dispõe sobre acondicionamento, coleta, tratamento, transporte e } \\
\text { destinação dos resíduos de serviços de saúde. }\end{array}$ \\
\hline $\begin{array}{c}\text { Lei } n^{0} 7.802 \text { - Lei dos Agrotóxicos/ Lei } \\
\text { no } 9.974 /\end{array}$ & $\begin{array}{c}\text { Alterada } \\
06 / 06 / 2000 \\
\end{array}$ & $\begin{array}{l}\text { Adicionou o tema da reciclagem de embalagens no art. } 6^{\circ} \text { da antiga lei, } \\
\text { estabelecendo que as embalagens de agrotóxicos e afins "devem ser } \\
\text { projetadas e fabricadas de forma a impedir qualquer vazamento, } \\
\text { evaporação, perda ou alteração de seu conteúdo e de modo a facilitar as } \\
\text { operações de lavagem, classificação, reutilização e reciclagem. } \\
\text { Impôs o sistema de logística reversa, obrigando os usuários a devolver } \\
\text { as embalagens vazias aos produtores e comerciantes. }\end{array}$ \\
\hline $\begin{array}{l}\text { Lei nº } 9.795 \text { - Política Nacional sobre } \\
\text { Educação Ambiental }\end{array}$ & $\begin{array}{l}27 \text { de abril } \\
\text { de } 1999\end{array}$ & $\begin{array}{l}\text { Entre os objetivos, descataram-se o de estimular a consciência sobre a } \\
\text { problemática ambiental e social, o incentivo à preservação do equilibrio } \\
\text { ambiental como parte do exercício da cidadania, assim como o incentivo } \\
\text { à integração da ciência e tecnologia (art. } 5^{\circ} \text {, III, IV e VI). }\end{array}$ \\
\hline Proposição Conama 259 & 1999 & $\begin{array}{l}\text { Intitulada Diretrizes Técnicas para a Gestão de Resíduos Sólidos. } \\
\text { Aprovada pelo plenário do conselho, mas não chegou a ser publicada. }\end{array}$ \\
\hline $\begin{array}{l}\text { Comissão Especial da Política } \\
\text { Nacional de Resíduos }\end{array}$ & 2001 & $\begin{array}{l}\text { Comissão criada na Câmara dos Deputados - objetivava a apreciação } \\
\text { das matérias contempladas ligadas ao Projeto de Lei } 203 / 91 \text { e formular } \\
\text { uma proposta substitutiva global. Com o encerramento da legislatura, a } \\
\text { Comissão foi extinta. }\end{array}$ \\
\hline $\begin{array}{c}1^{\circ} \text { Congresso Nacional dos Catadores } \\
\text { de Materiais Recicláveis }\end{array}$ & 2001 & $\begin{array}{c}\text { Realizado em Brasília, com } 1.600 \text { congressistas, entre catadores, } \\
\text { técnicos e agentes sociais de } 17 \text { estados. }\end{array}$ \\
\hline O II gresso Latino-Americano de & 2003 & $\begin{array}{l}\text { Realizado em Caxias do Sul. Propõe formação profissional, erradicação } \\
\text { dos lixões e responsabilização dos geradores de resíduos. }\end{array}$ \\
\hline 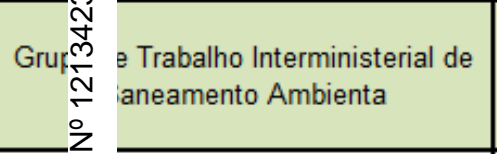 & 2003 & $\begin{array}{c}\text { Criação do grupo instituído pelo Presidente Lula, para promover a } \\
\text { integração das ações de saneamento ambiental, no âmbito do governo } \\
\text { federal. O GT reestrutura o setor de saneamento e resulta na criação do } \\
\text { Programa Resíduos Sólidos Urbanos. }\end{array}$ \\
\hline 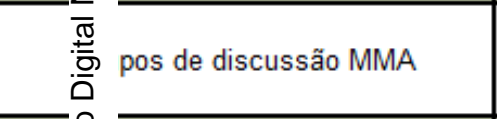 & 2004 & $\begin{array}{c}\text { Grupos de discussões interministeriais e de secretarias do ministério } \\
\text { para elaboração de proposta para a regulamentação dos resíduos } \\
\text { sólidos }\end{array}$ \\
\hline 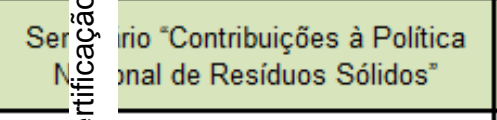 & 2004 & \begin{tabular}{|c} 
Coordenado pelo Conama, com objetivo de ouvir a sociedade e formular \\
nova proposta de projeto de lei, com a defasagem da Proposição \\
Conama 259 .
\end{tabular} \\
\hline 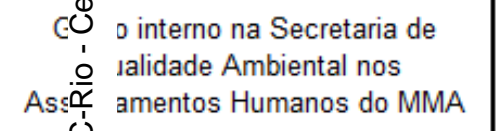 & 2005 & $\begin{array}{l}\text { Buscou consolidar contribuições do Seminário Conama, os anteprojetos } \\
\text { de lei existentes no Congresso Nacional e as contribuições dos diversos } \\
\text { atores envolvidos na gestão de resíduos sólidos. }\end{array}$ \\
\hline Decreto $n^{\circ} 5940$ & 2006 & $\begin{array}{c}\text { Instituiu a separação dos resíduos recicláveis descartados pelos órgãos } \\
\text { públicos federais e a sua destinação às cooperativas de catadores de } \\
\text { materiais recicláveis. }\end{array}$ \\
\hline \multirow{2}{*}{ Lei $n^{\circ} 11.445$} & \multirow{2}{*}{$\begin{array}{l}5 \text { de janeiro } \\
\text { de } 2007\end{array}$} & $\begin{array}{c}\text { Estabeleceu as diretrizes nacionais para o saneamento básico. } \\
\text { Art } 7^{\circ} \text { - define que, para os efeitos desta Lei, a coleta, transporte, } \\
\text { triagem para fins de reuso e reciclagem, tratamento e disposição final } \\
\text { dos resíduos estão contidos no serviço público de limpeza urbana e no } \\
\text { manejo de resíduos sólidos urbanos. }\end{array}$ \\
\hline & & $\begin{array}{l}\text { Além disso, a citada lei estabeleceu que a União criasse, junto ao } \\
\text { Ministério das Cidades, um Plano Nacional de Saneamento Básico } \\
\text { (PlanSab) que, entre outros objetivos, deverá abranger o tema do manejo } \\
\text { de resíduos sólidos, como explicitado no I do parágrafo } 1^{\circ} \text {, art. } 52 \text {. }\end{array}$ \\
\hline Resolução RDC n² 20 & $\begin{array}{c}26 \text { de março } \\
\text { de } 2008\end{array}$ & $\begin{array}{l}\text { Agência Nacional de Vigilância Sanitária (ANVISA) liberou o uso de } \\
\text { garrafas PET pós-consumo recicladas para uso em embalagens de } \\
\text { alimentos no Brasil. } \\
\text { A Resolução da Agência teve como base o surgimento de novas } \\
\text { tecnologias capazes de limpar e descontaminar esse tipo de material. }\end{array}$ \\
\hline
\end{tabular}

Tabela 6 - Evolutivo de legislações ambientais. Criada a partir de dados de Capelini, $2007 \mathrm{e}$ MMA, 2012. 
[...]"X - regularidade, continuidade, funcionalidade e universalização da prestação dos serviços públicos de limpeza urbana e de manejo de resíduos sólidos, com adoção de mecanismos gerenciais e econômicos que assegurem a recuperação dos custos dos serviços prestados, como forma de garantir sua sustentabilidade operacional e financeira, observada a Lei ํo 11.445, de 2007;

$\mathrm{XI}$ - prioridade, nas aquisições e contratações governamentais, para:

a) produtos reciclados e recicláveis;

XII - integração dos catadores de materiais reutilizáveis e recicláveis nas ações que envolvam a responsabilidade compartilhada pelo ciclo de vida dos produtos;

XIV - incentivo ao desenvolvimento de sistemas de gestão ambiental e empresarial voltados para a melhoria dos processos produtivos e ao reaproveitamento dos resíduos sólidos, incluídos a recuperação e o aproveitamento energético" [...].

São apresentados 19 (dezenove) instrumentos da Política, ferramentas utilizadas para a busca dos objetivos. Dentre estes, 3 (três) são de extrema importância para o assunto em questão:

[...] "III - a coleta seletiva, os sistemas de logística reversa e outras ferramentas relacionadas à implementação da responsabilidade compartilhada pelo ciclo de vida dos produtos;

IV - o incentivo à criação e ao desenvolvimento de cooperativas ou de outras formas de associação de catadores de materiais reutilizáveis e recicláveis" [...];

[...] "VI - a cooperação técnica e financeira entre os setores público e privado para o desenvolvimento de pesquisas de novos produtos, métodos, processos e tecnologias de gestão, reciclagem, reutilização, tratamento de resíduos e disposição final ambientalmente adequada de rejeitos;

VII - a pesquisa científica e tecnológica" [...]";

[...] "XIX - o incentivo à adoção de consórcios ou de outras formas de cooperação entre os entes federados, com vistas à elevação das escalas de aproveitamento e à redução dos custos envolvidos."

Diretrizes Aplicáveis aos Resíduos Sólidos - dividido em 6 (seis) capítulos: disposições preliminares, planos de resíduos sólidos, responsabilidades dos geradores e do poder público, resíduos perigosos, instrumentos econômicos, e proibições, nesta ordem.

Em Disposições, 0 art. $9^{\circ}$ enfatiza a ordem de prioridade para 0 tratamento de resíduos: a não geração, redução, reutilização, reciclagem, tratamento dos resíduos sólidos e disposição final ambientalmente adequada dos rejeitos.

Também abre a possibilidade para a utilização de tecnologias, conforme aborda este estudo, desde que tenha sido comprovada sua viabilidade técnica e ambiental. 
No art. 15 consta que a União elaborará, sob a coordenação do Ministério do Meio Ambiente, o PNRS, com vigência por prazo indeterminado e horizonte de 20(vinte) anos, a ser atualizado a cada 4 (quatro) anos, tendo como conteúdo mínimo o inciso III, que impõe metas de redução, reutilização e reciclagem, entre outras, com vistas a reduzir a quantidade de resíduos e rejeitos encaminhados para disposição final ambientalmente adequada.

O art. 16 coloca a elaboração do plano estadual de resíduos sólidos como condição para os estados terem acessos a recursos da União, ou por ela controlados, destinados a empreendimentos e serviços relacionados à gestão de resíduos sólidos, ou para serem beneficiados por incentivos ou financiamentos de entidades federais de crédito ou fomento para tal finalidade.

Tal condição tem contribuído para o surgimento de planos e até mesmo ações estaduais.

Destaca-se também a Seção IV do Capítulo II, sobre planos municipais de gestão integrada de resíduos sólidos. O § 10, inciso II do art. 18 também estabelece prioridade de acesso aos recursos da União para os municípios que tiverem programas de coleta seletiva com a participação de catadores e cooperativas.

O art. 17 discorre sobre as mesmas obrigações, em nível estadual. Os Estados também deverão elaborar e implementar planos de resíduos sólidos para microrregiões, regiões metropolitanas ou conglomerados urbanos, estabelecendo que o plano microrregional de resíduos sólidos deve atender ao previsto para o plano estadual e estabelecer soluções integradas para a coleta seletiva, a recuperação e a reciclagem, o tratamento e a destinação final dos resíduos sólidos urbanos e, consideradas as peculiaridades microrregionais, outros tipos de resíduos.

Ainda com relação aos Municípios, o art. 19 trata do conteúdo mínimo dos planos de gestão. O item III aborda soluções que visem economia de escala, os itens IX X e XI, sobre programas e ações de capacitação técnica e educação ambiental que promovam a não geração, a redução, a reutilização e a reciclagem de resíduos sólidos.

O item XII aborda mecanismos para a criação de fontes de negócios, emprego e renda, mediante a valorização dos resíduos sólidos.

E, como para os Estados, o XIV prevê a elaboração de metas de redução, reutilização, coleta seletiva e reciclagem, entre outras, com vistas a reduzir a quantidade de rejeitos encaminhados para disposição final ambientalmente adequada.

Tendo em vista os geradores de resíduos sólidos, o plano de gerenciamento tem, como descrito no art. 21, metas e procedimentos relacionados à minimização da geração de resíduos sólidos e, observadas 
as normas estabelecidas pelos órgãos do Sisnama, do SNVS e do Suasa, à reutilização e reciclagem $(\mathrm{VI})$;

$\mathrm{O}$ art. 30 dispõe sobre a responsabilidade compartilhada pelo ciclo de vida dos produtos, dando enfoque à sustentabilidade (I e IV), à redução da geração e o aproveitamento dos resíduos sólidos na sua própria ou em outras cadeias produtivas (II e III) e estimulando o desenvolvimento de mercado, a produção e o consumo de produtos derivados de materiais reciclados e recicláveis.

Os consumidores, comerciantes e fabricantes são todos responsáveis para que a logística reversa funcione, de acordo com os parágrafos $4^{\circ}, 5^{\circ}$ e $6^{\circ}$.

A Política impõe certas responsabilidades ao consumidores, como é o caso de municípios que possuem programas de coleta seletiva.

$\mathrm{O}$ art. 36 responsabiliza o titular dos serviços públicos de limpeza urbana e de manejo de resíduos sólidos a implantar um sistema de compostagem para resíduos sólidos orgânicos e articular com os agentes econômicos e sociais formas de utilização do composto produzido;

A lei 12.305/2010 também dispõe sobre instrumentos econômicos que facilitem o financiamento das medidas por ela apresentadas, a fim de incentivar sua implementação.

$\mathrm{O}$ art. 42 trata da prioridade de fomento a diversas iniciativas, dentre elas, os itens abaixo, diretamente envolvidos com a implantação do TMB.

[...] "I - prevenção e redução da geração de resíduos sólidos no processo produtivo";

[...] "III - implantação de infraestrutura física e aquisição de equipamentos para cooperativas ou outras formas de associação de catadores de materiais reutilizáveis e recicláveis formadas por pessoas físicas de baixa renda";

[...] "VII - desenvolvimento de pesquisas voltadas para tecnologias limpas aplicáveis aos resíduos sólidos".

\subsection{O Tratamento Mecânico e Biológico (TMB)}

O sistema TMB é um processo complexo, flexível e de diversas variações para o tratamento de resíduos indiferenciados ou simplesmente RSU (resíduos sólidos urbanos), objetivando o melhor aproveitamento possível, reduzindo a parcela residual para a destinação final.

Com a evolução da coleta seletiva e conscientização da sociedade no que diz respeito ao tratamento do lixo, muitas unidades na União Européia tratam somente as partes secas em suas unidades de TMB, porém ainda existem algumas que tratam o RSU. 
O conceito, originado na Alemanha e Áustria, envolvia todos os sistemas mecânicos e biológicos utilizados para a redução do lixo, que poderiam ser utilizados separadamente. Ao longo do tempo, o termo evoluiu para definir sistemas integrados que utilizassem o tratamento mecânico e biológico dentro de um mesmo processo.

Conforme o nome descreve, o processo divide-se em duas fases:

- mecânica - envolve meios de separação que removem algumas frações de resíduos de forma mecânica, como a separação por tamanho ou peso, recuperando materiais para reciclagem;

- biológica - envolve meios para estabilizar a fração orgânica para que suas características tornem-se razoáveis para outras utilizações (JUNIPER,2005).

Juniper (2005) enumera as principais vantagens na utilização da tecnologia, conforme a seguir.

- Maior aproveitamento de resíduos secos para a reciclagem;

- Redução do volume de resíduos para destino final;

- Redução da umidade e volume da fração orgânica;

- Aproveitamento da fração orgânica em composto ou energia;

- Redução do potencial de formação de gás (gás de efeito de estufa e odores no aterro).

Em contrapartida, Stephanie (2011) apresenta desafios técnicos, econômicos e ambientais avaliados em 61 plantas da Alemanha, que somam uma capacidade total de 6,4 milhões de toneladas/ano.

- Alto nível de desgaste de equipamentos;

- Grande número de paradas na produção e contaminação no separador balístico;

- Diferenças representativas entre o planejado e o real no que diz respeito ao tempo para manutenção e limpeza, quantidade de pessoas e gasto de energia;

- Alta variação da produção de biogás, devido à entrada descontínua de substrato.

De acordo com Stephanie (2011), o custo para utilização desta tecnologia é similar ao gasto com a incineração na UE: 100 Euros por tonelada.

De acordo com os tratamentos biológicos escolhidos para utilização na planta, os principais produtos gerados são composto e fertilizantes para o solo, biogás para a geração de calor e/ou energia eléctrica e combustível CDR (Combustível Derivado de Resíduos), também utilizado para a geração de energia elétrica.

A Figura 15 apresenta um diagrama esquemático do processo em termos gerais. 


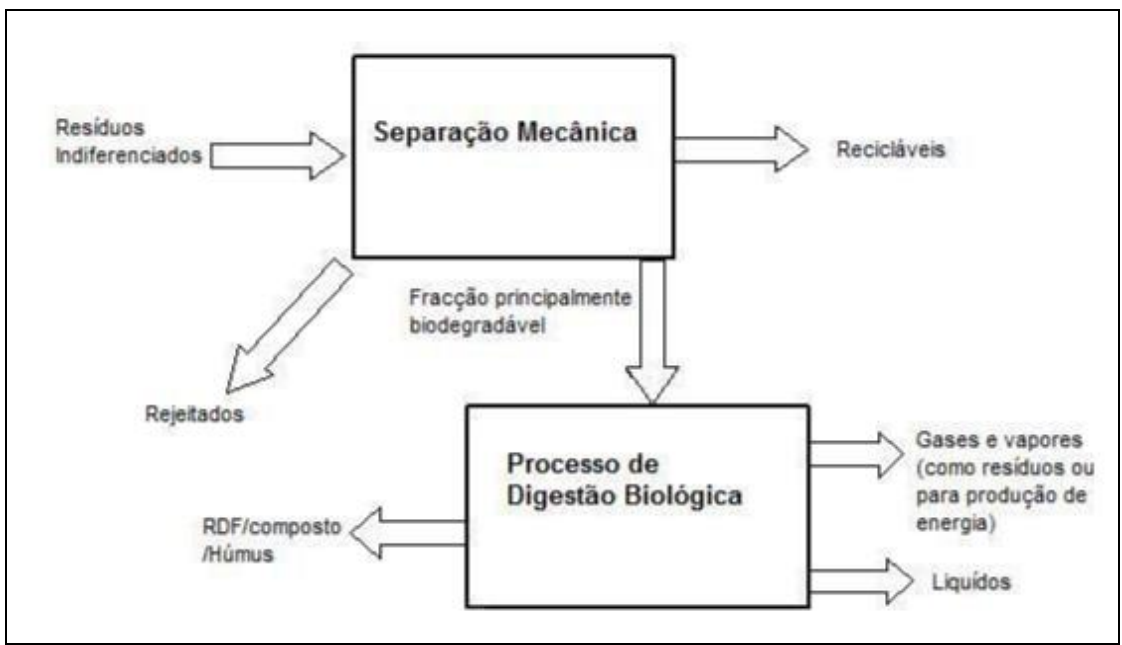

Figura 15 - Descrição geral do processo TMB. Fonte: Teixeira, 2009.

Um grande número de combinações entre os processos são possíveis para o TMB, devido à grande variedade de elementos mecânicos e biológicos que podem ser implementados, adaptando cada processo às características de cada local.

Algumas plantas têm foco na potencialização de material orgânico com foco na compostagem, outras utilizam a compostagem e digestão anaeróbica, outras a produção de CDR, separação de material para reciclagem ou até mesmo a simples redução para envio à incineração.

Juniper (2005) demonstra a avaliação 80 plantas, gerenciadas por 27 corporações e utilizadas por países da União Européia, somando 8 milhões de toneladas de resíduos por ano, com capacidades variando entre 50.000 e 200.000 ton por ano.

Aproximadamente um terço do total produz biogás a partir da digestão anaeróbica, 14 plantas (18\%) produzem o CDR, 27\% estabilizam o resíduo para envio ao aterro e 23 plantas (28\%) enviam o composto para o tratamento da terra.

No que diz respeito ao aproveitamento de material reciclável, $74 \%$ das unidades separam o metal, 10 (13\%) aproveitam vidro, 28\% comercializam o papel e $73 \%$ das plantas aproveitam o plástico.

Os percentuais informados não somam $100 \%$, já que as unidades geram diversos produtos num mesmo processo.

\subsubsection{O Tratamento Mecânico - detalhamento}

A parte do tratamento mecânico envolve várias técnicas que poderão ser utilizadas de acordo com os objetivos a atingir, bem como o tipo de resíduos que se quer tratar. Nesta fase, os mecanismos existentes realizam as seguintes ações (Juniper, 2002): 
- Abertura de sacos do lixo;

- Retirada de constituintes inapropriados (volumosos), que podem obstruir os processos subsequentes;

- Separação/triagem dos materiais recicláveis (plásticos, papel/cartão, vidro e metais);

- Separação de materiais biodegradáveis;

- Separação/preparação dos materiais com um valor calorífico elevado, (têxteis, papel/cartão e plásticos) que não possam ser reciclados;

- Homogeneização e preparação dos materiais para o tratamento biológico;

- Afinação do composto ou fração orgânica estabilizada (resultado da fase biológica).

Relativamente ao pré-tratamento de resíduos numa UTMB, este processo consiste em separar a fração orgânica de outros tipos de resíduos que não são utilizados para decomposição aeróbia ou anaeróbia, considerados contaminantes como vidros, plásticos, papel, cartão, têxteis e volumosos.

A maior parte das técnicas de pré-tratamento aplicadas são de natureza mecânica. As UTMB podem incluir diversos destes processos em vários circuitos, porém a grande maioria envolve separação por tamanho e peso. (Teixeira, 2009):

Seguem as operações unitárias pelas quais os resíduos passam numa UTMB, na ordem descrita, segundo Teixeira (2009), conforme a Figura 16.

\subsubsection{1. $\quad$ Abre Sacos}

Normalmente, a fração orgânica que chega às UTMB vem fechada em sacos plásticos.

Há alguns anos atrás, a metodologia utilizada para romper esses sacos consistia na instalação de lâminas no tambor do crivo rotativo. Atualmente, existem métodos mais eficazes através da utilização de máquinas abre-sacos, que além de rompê-los, dosam o material que segue na esteira transportadora para as fases seguintes do processo.

Estas máquinas têm normalmente um rotor com lâminas incorporadas em forma de espiral e um conjunto de lâminas fixas, cuja abertura de corte pode ser regulada. Esta regulagem pode controlar o estado e o fluxo de material que sai.

A possibilidade de abrir ou rasgar sacos é tipicamente conseguida através do atrito, normalmente em tambores com facas, ou os designados abridores de sacos que permitem que o seu conteúdo se espalhe. 


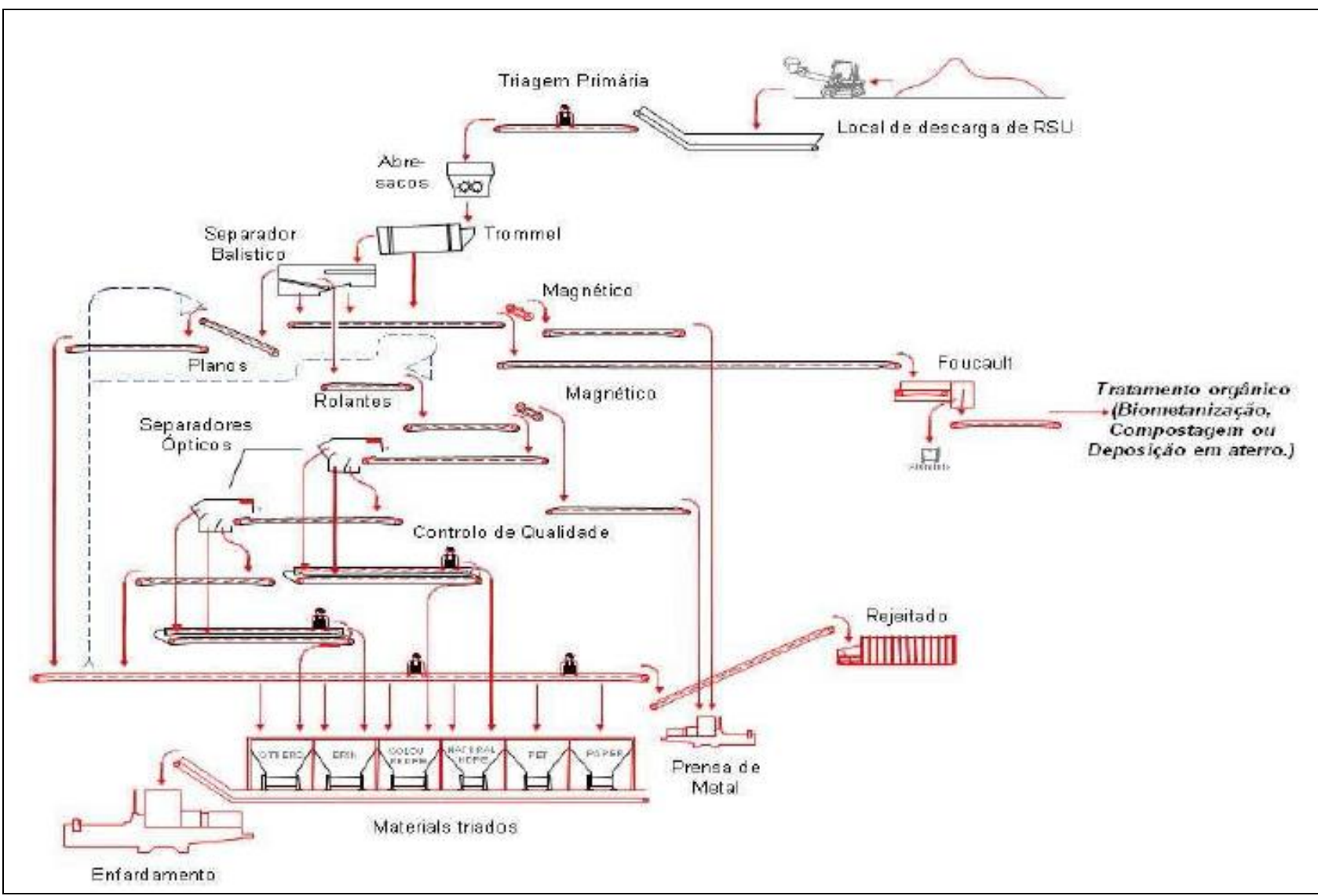

Figura 16 - Descrição esquemática dos equipamentos de uma UTMB.

Fonte: Teixeira, 2009.

\subsubsection{Pré Triagem Manual}

Após a abertura dos sacos, o material que se encontrava no seu interior encontra-se solto, o que facilita uma operação de pré-triagem manual.

Esta etapa é especialmente importante, devido ao grau de heterogeneidade dos RSU. Os principais materiais removidos nesta fase são os volumosos e os vidros.

\subsubsection{Crivo Rotativo/Trommel}

A existência de um crivo rotativo, também designado por trommel numa instalação de pré- tratamento para compostagem é indispensável.

Este equipamento permite a separação de materiais de diferentes dimensões e é constituído por um tambor perfurado e montado com uma ligeira inclinação.

Este tambor rotativo faz com que a fração fina, considerada orgânica, passe através dos orifícios do tambor, enquanto a fração de dimensões superiores seja expelida pelo lado contrário do tambor. 
Estes equipamentos constituem máquinas muito robustas, de manutenção simples e de fácil acesso a todas as unidades.

É possível dimensioná-las para separar até três tipos de tamanho diferentes. Normalmente, a parte fina que cai pelos orifícios vai diretamente para valorização orgânica, a de dimensões médias segue para um separador balístico e a parte menor é encaminhada para uma linha de triagem para recuperação de materiais para reciclagem.

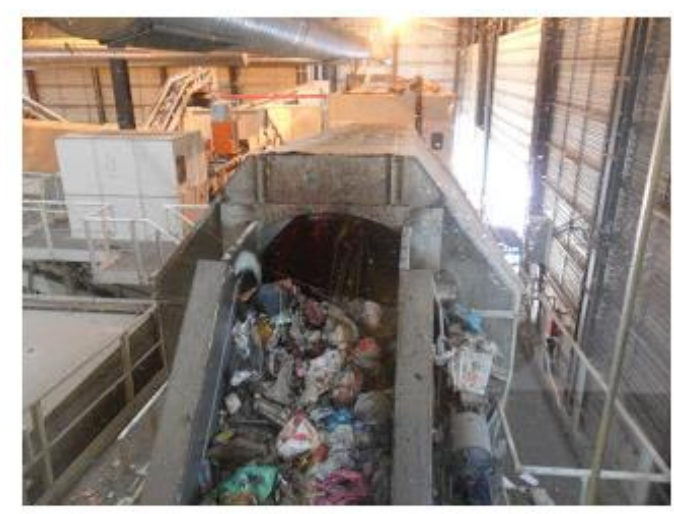

Figura 17 - Foto de um Trommel.

Fonte: Valnor, 2014.

\subsubsection{Separador balístico}

O equipamento designado por separador balístico pode separar até três tipos de resíduos. Este equipamento é alimentado, como referido anteriormente com a parte média, proveniente do crivo rotativo.

O separador balístico é constituído por um conjunto de chapas perfuradas que estão montadas inclinadamente, paralelas umas às outras.

Os resíduos orgânicos que não foram retirados pela malha mais fina do crivo rotativo são agora recuperados pelos orifícios destas chapas e encaminhados para junto deste grupo, com destino ao processo de compostagem.

A inclinação das chapas possibilita que os materiais mais pesados, volumosos e com formato mais arredondado (materiais rolantes) sejam conduzidos para a parte inferior, por efeito da gravidade.

Estes resíduos são maioritariamente constituídos por embalagens, que devem ser recolhidas por um tapete transportador e encaminhados para uma linha de triagem para aproveitamento dos materiais cujo destino é a reciclagem.

Os materiais planos, devido ao movimento das placas, deslocam-se para a parte superior. Estes se unem ao grupo de maiores dimensões originados do crivo rotativo e seguem para uma linha de triagem de papel/cartão, sendo aproveitados para reciclagem após remoção de contaminantes. 


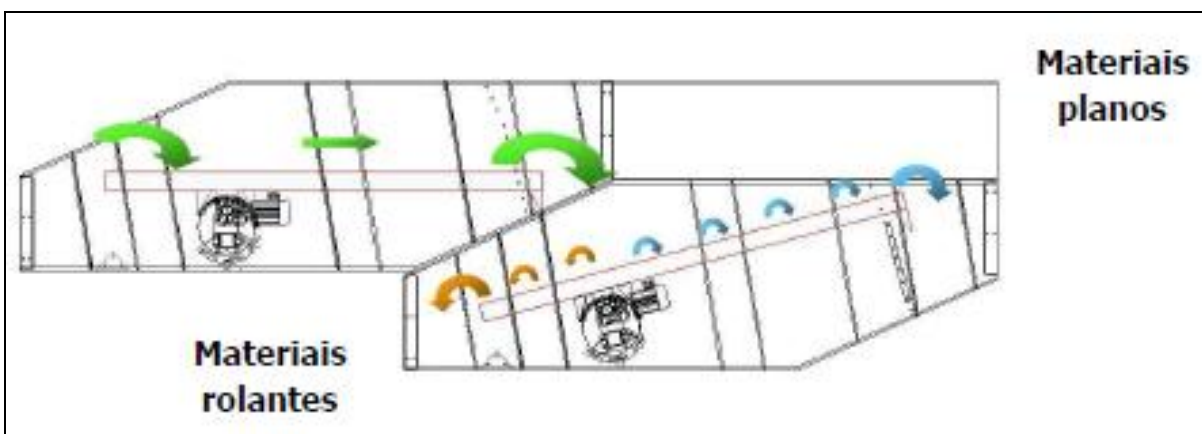

Figura 18 - Esquema funcional de um separador balístico. Fonte: Teixeira, 2009.

\subsubsection{Separador Magnético}

O separador magnético é um equipamento de grande importância numa unidade de pré- tratamento e constitui a última etapa pela qual a parte orgânica passa antes de seguir para valorização.

Como o nome indica, é constituído por um eletroímã, estrutura principal e de suporte a uma pequena tela nervurada que o envolve.

Os elementos ferrosos que circulam nos resíduos espalhados pelo tapete ao entrar no campo magnético gerado pelo eletroíman, são atraídos e vão de encontro à tela transportadora que o rodeia.

Os ferrosos são arrastados pela nervura da tela para fora do alcance do campo magnético desprendendo-se para uma cuba. Este equipamento tanto pode ser montado de forma transversal sobre o tapete, como de forma longitudinal na cabeça do mesmo.

\subsubsection{Corrente de Focault}

Os materiais não-ferrosos como o alumínio, são separados através de um equipamento denominado corrente de Foucault que funciona através de indução do material que passa nas esteiras.

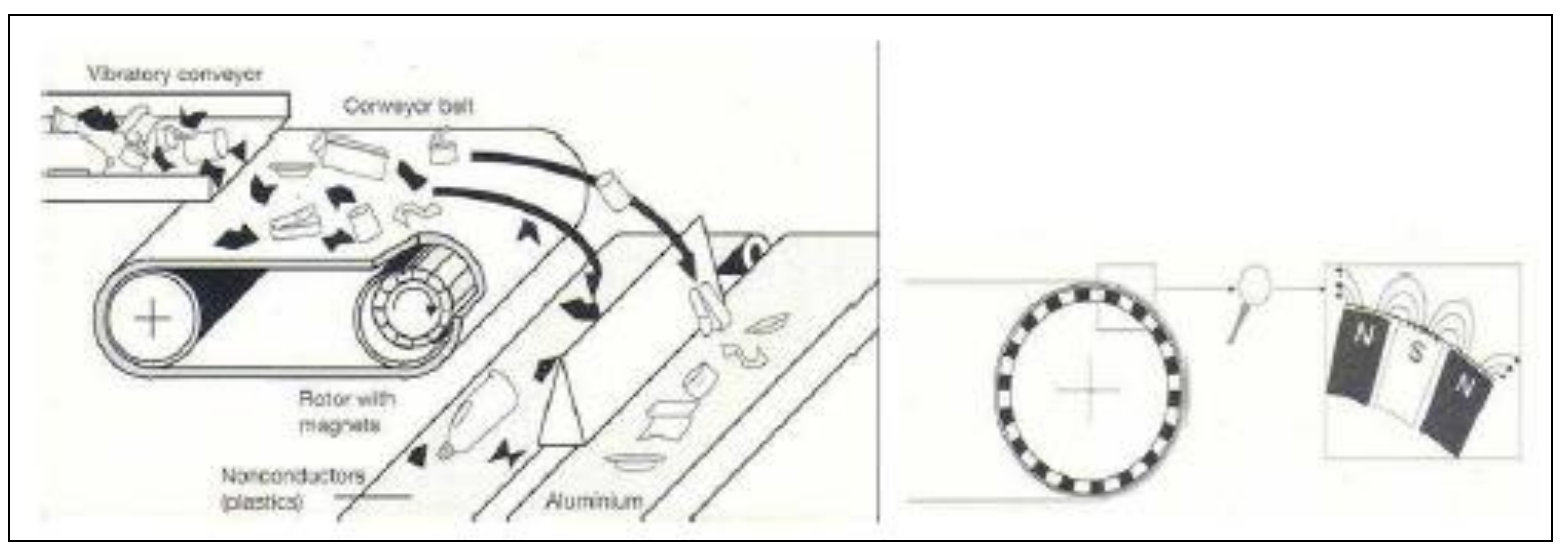

Figura 19 - Separador balístico - figura esquemática. Fonte: Teixeira, 2009. 


\subsubsection{Separador Ótico}

O separador ótico é um equipamento que possibilita a triagem de acordo com o tipo de material, cor e forma.

Através de uma válvula de ar propulsionado na fração desejada, é possível separar o grupo valorizado do indesejado, que cai numa esteira transportadora, tal como se demonstra na Figura 20.

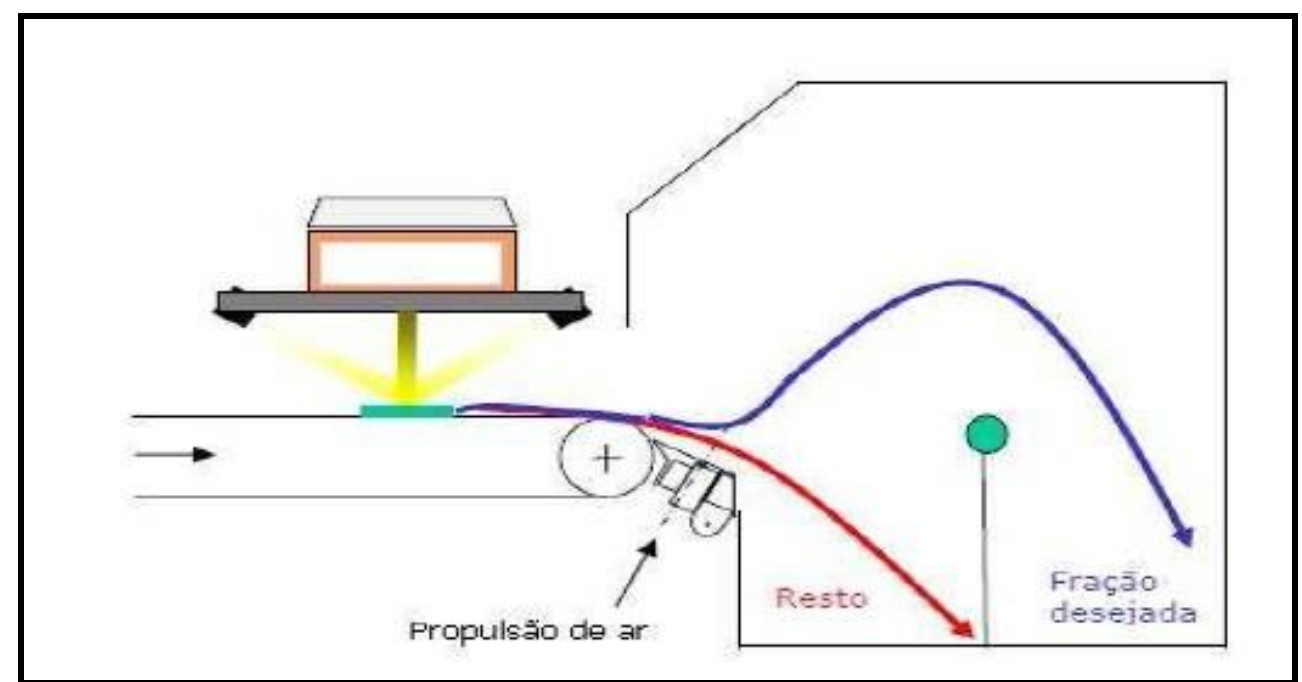

Figura 20 - Esquema de separação através de separação ótica (Teixeira, 2009).

Note-se que nas estações automatizadas, os separadores ópticos e por fluxo de ar atuam nos materiais rolantes, com o intuito de maximizar os recicláveis de plástico encaminhados para reciclagem, normalmente embalagens de PET e PEAD, bem como o alumínio, nos casos em que não exista nenhuma separação de metais não-ferrosos por corrente de Foucault .

\subsubsection{8. $\quad$ Sistema de aspiração}

Algumas estações de TMB possuem no seu tratamento mecânico sistemas de aspiração, cujo objetivo primordial consiste em aspirar material filme plástico, permitindo uma maior eficácia da separação dos outros materiais que ficam muito mais disponíveis e espalhados nas esteiras.

Após a separação dos materiais recicláveis obtidos a partir do TM, sobram dois grupos importantes:

- a matéria orgânica e materiais inertes, de pequenas dimensões que contêm areias, vidro, restos cerâmicos e ainda restos de papéis e plásticos, que seguem para o TB.

- os resíduos que não possuem viabilidade para reciclagem, denominados refugo ou rejeito, podem ser direcionados para o CDR, visando a valorização energética (com ou sem trituração prévia). 


\subsubsection{Tratamento Biológico}

Esta fase do processo pode ser realizada de duas formas: método anaeróbico (digestão anaeróbia) ou aeróbico (compostagem ou vermicompostagem), fatores já abordados no Capítulo 2 deste estudo.

Considera-se reciclagem o composto ou o digerido obtido aplicado no solo ou utilizado em outros processos produtivos. Caso o tratamento biológico seja utilizado para a única estabilização e redução do volume para envio à destinação final, classifica-se como pré- tratamento para a deposição em aterro. 


\section{CENÁRIO ATUAL}

Neste capítulo, o panorama brasileiro da Gestão de Resíduos Sólidos Urbanos será abordado, avaliando a situação real frente às metas estabelecidas tanto na Lei 12.305/2010, no Plano Nacional de Resíduos Sólidos e seus desdobramentos estaduais e municipais.

Tal situação será detalhada no nível do Estado do Rio de Janeiro, bem como o município, foco deste estudo.

\subsection{Gestão de Resíduos no Brasil}

O Brasil apresenta população total de 200 milhões de habitantes, PIB per capita de R\$24 mil ou US\$11,7 (IBGE,2013 apud PNRS, 2010) e ocupa a $79^{a}$ na lista do IDH, dentre os 187 países analisados pela ONU, alcançando o resultado de 0,744 (PNUD, 2013 apud PNRS, 2010). O país apresenta crescimento representativo neste indicador, que iniciou-se com 0,493 em 1991.

Por apresentar características de um país em desenvolvimento, como o crescimento não planejado das cidades, grande desigualdade social e baixo investimento em meio ambiente, saúde e educação, apresenta uma situação ambiental não muito favorável, como mostram estudos de diversos órgãos que serão detalhados a seguir.

O relatório divulgado na COP17 (PNUMA, 2011 apud PNRS, 2010) lista os países que mais emitem gases de efeito estufa, causador direto do aquecimento global. O Brasil aparece na $6^{\circ}$ posição, atrás do Japão, Rússia, Índia, Estados Unidos e China, especificamente nesta ordem. Um conjunto de 10 países é responsável pela emissão de 2/3 dos GEE. Atrás do Brasil, seguem Alemanha, Canadá, México e Irã.

O Inventário de Gases Efeito Estufa da CETESB (CETESB, 2013) demonstra o evolutivo de emissões brasileiras, dividido em cinco setores: Energia, Uso da Terra e Florestas, Agropecuária, Processos Industriais e Tratamento de Resíduos, conforme a Figuras 21.

Este último setor, diretamente relacionado ao tema deste estudo, apresenta a segunda maior variação, perdendo somente para o fator Energia.

De acordo com o Panorama de Resíduos (ABRELPE, 2012), geramos 76.387.200 toneladas de resíduos sólidos urbanos (RSU) em 2013, o que representa um aumento de 4,1\% frente ao mesmo indicador de 2012 .

Este índice é superior à taxa de variação populacional no país no período, que apresentou crescimento de 3,7\%. O dado de geração diária em 2013, comparado com 2012, é apresentado nas Figura 22. 


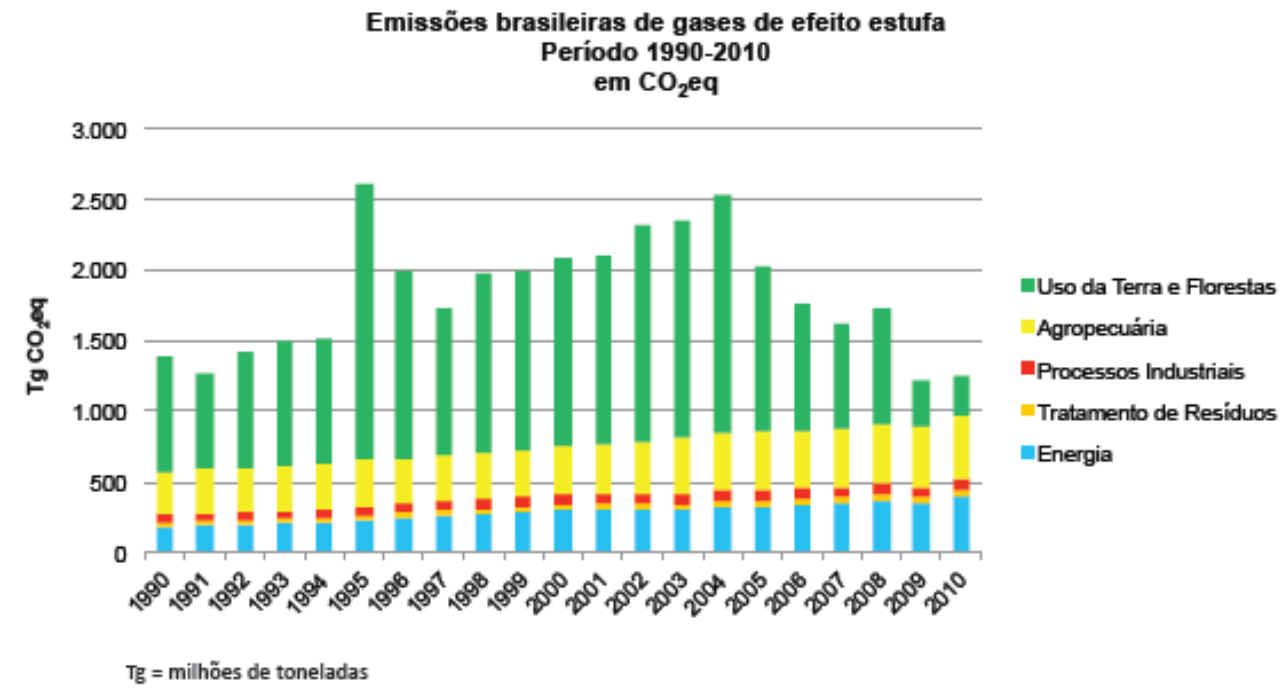

\begin{tabular}{|c|c|c|c|c|c|c|c|}
\hline \multirow{2}{*}{ Setores } & 1990 & 1995 & 2000 & 2005 & 2010 & \multicolumn{2}{|c|}{ Variação } \\
\hline & & & $\mathrm{Gg} \mathrm{CO}_{2} \mathrm{eq}$ & & & $1995-2005$ & $2005-2010$ \\
\hline Energia & 191.543 & 232430 & 301.096 & 328.808 & 389.302 & $41,5 \%$ & $21,4 \%$ \\
\hline Processos Industriais & 52.536 & 63.065 & 71.673 & 77.943 & 82.048 & $23,6 \%$ & $5,3 \%$ \\
\hline Agropecuária & 303.772 & 335.775 & 347.878 & 415.713 & 437.226 & $23,8 \%$ & $5,2 \%$ \\
\hline Florestas & 815.965 & 1.850 .084 & 1.324 .371 & 1.167.917 & 279.163 & $-40,1 \%$ & $-76,1 \%$ \\
\hline Resíduos & 28.939 & 33.808 & 38.550 & 41.880 & 48.737 & $23,9 \%$ & $16,4 \%$ \\
\hline TOTAL & 1.392 .756 & 2.615 .162 & 2083.570 & 2.032 .260 & 1.246 .477 & $-22,3 \%$ & $-38,7 \%$ \\
\hline
\end{tabular}

$\mathrm{Gg}=$ milhares de toneladas

Figura 21 - Emissões brasileiras de GEE. Fonte: CETESB, 2013.

O volume gerado per capita é próximo ao de cidades mundiais: 1,041 $\mathrm{kg} / \mathrm{hab} / \mathrm{dia}$, com variação significante entre as principais capitais e demais cidades.

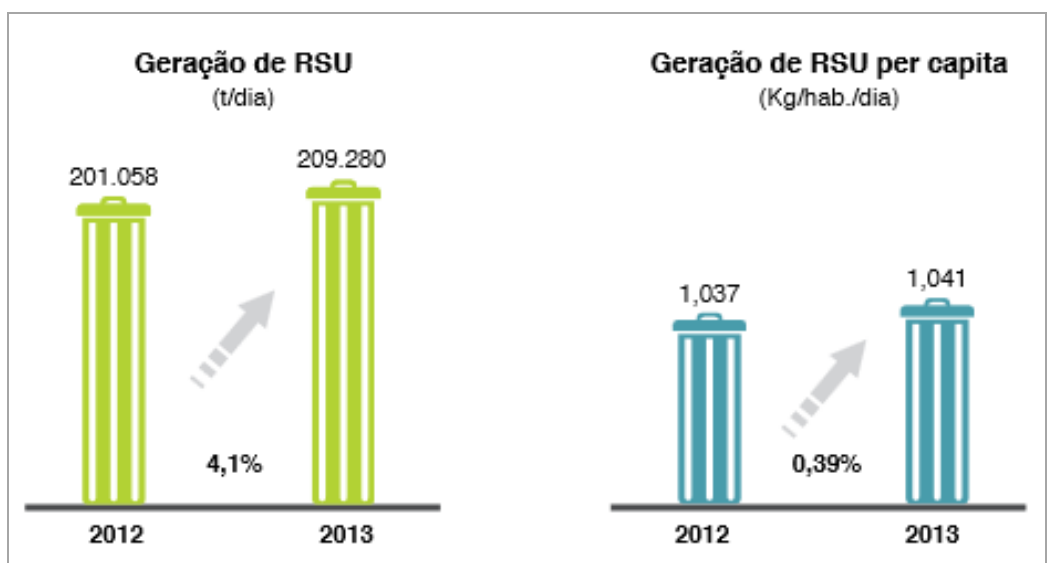

Figura 22 - Geração brasileira de RSU - total e per capita - 2012/2013. Fonte: ABRELPLE, 2013. 


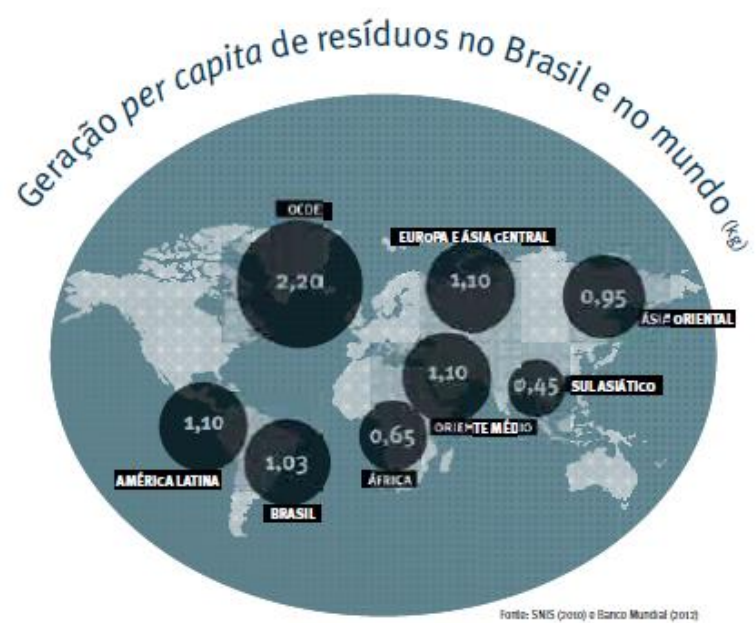

Figura 23 - Geração per capita de RSU - comparativo Brasil e demais países. Fonte: ABRELPLE, 2013.

O Plano Nacional de Resíduos Sólidos (2011) apresenta um valor médio de $70,00 \mathrm{R} \$$ /habitante para custos com a gestão de resíduos no geral.

O relatório da Abrelpe (2013) detalha este custo em despesas com coleta e demais serviços de limpeza, incluindo neste as despesas com a destinação final dos RSU.

Os valores apresentados na Figura 24 revelam que em 2013 os municípios aplicaram, em média, $\mathrm{R} \$ 114,84$ por habitante/ano na coleta de RSU e demais serviços de limpeza urbana.(ABRELPE, 2013)

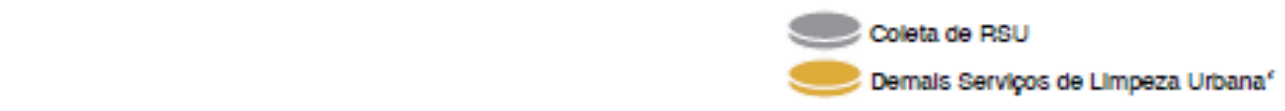

2013

RShab.kano

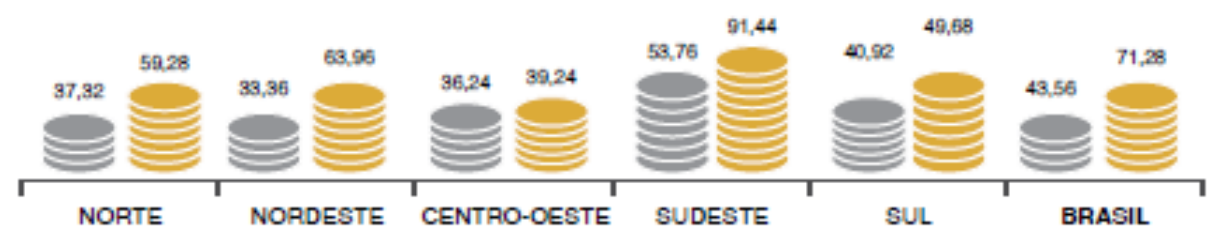

Figura 24 - Gasto unitário pela coleta de RSU e outros serviços de limpeza urbana. Fonte: ABRELPLE, 2013.

Além dos pontos demonstrados acima, a Gestão de RSU faz-se importante também no Brasil pela geração de empregos envolvida. A Figura 25 mostra que a geração de empregos no setor de limpeza urbana cresceu $3,6 \%$ em relação ao ano anterior, superando os 332 mil empregos diretos. 


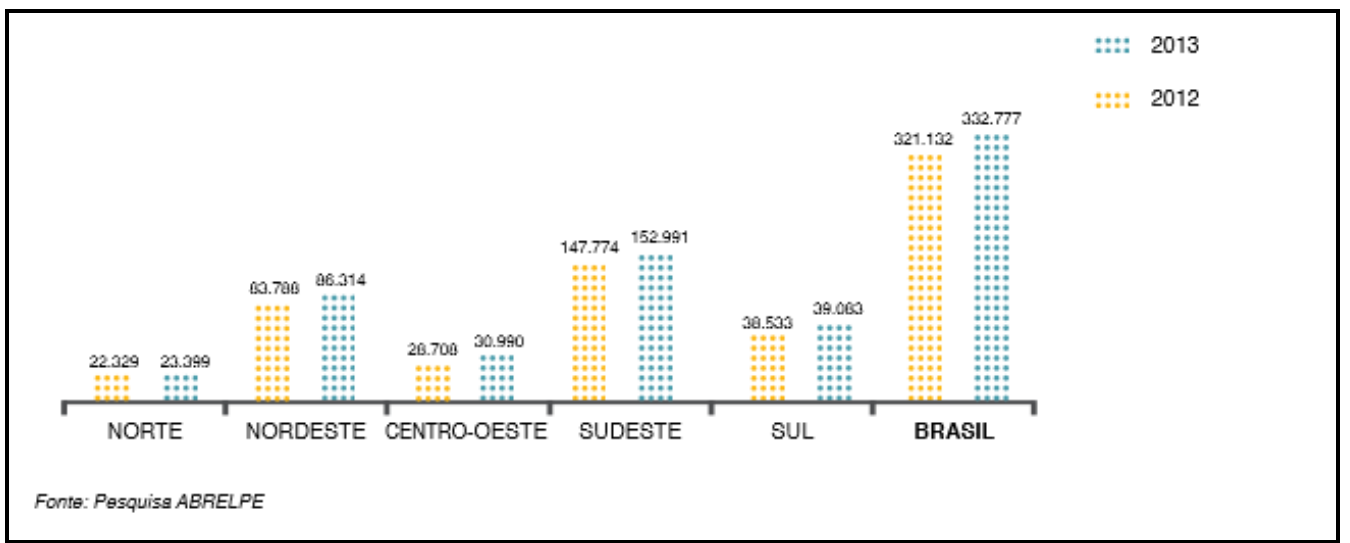

Figura 25 - Empregos diretos gerados pelo setor de limpeza urbana - Regiões e Brasil. Fonte: ABRELPLE, 2013.

O mercado de limpeza urbana, que nos anos anteriores movimentou considerável volume de recursos, novamente demonstra a sua relevância no cenário econômico do país ao ultrapassar a casa dos 24 bilhões de reais, indicando um crescimento em todas as regiões do país e um aumento superior a $6,5 \%$ no Brasil como um todo.

\subsubsection{Destinação Final de RSU}

Mesmo com a publicação da PNRS desde 2010, grande parte do volume gerado ainda é destinado de forma incorreta.

De acordo com o Relatório do CEMPRE (2013), o Brasil destinou 80,3\% dos resíduos a lixões, aterros controlados e sanitários, 9,6\% queimados em propriedades privadas, $7,2 \%$ disposto em caçambas, $2 \%$ jogado em terreno baldio, $0,6 \%$ enterrado em propriedades e $0,3 \%$ enviados a outros tipos destinações não descritas.

Comparando-se a países europeus conforme a Figura 26, a posição do Brasil apresenta inúmeras oportunidades de melhoria.

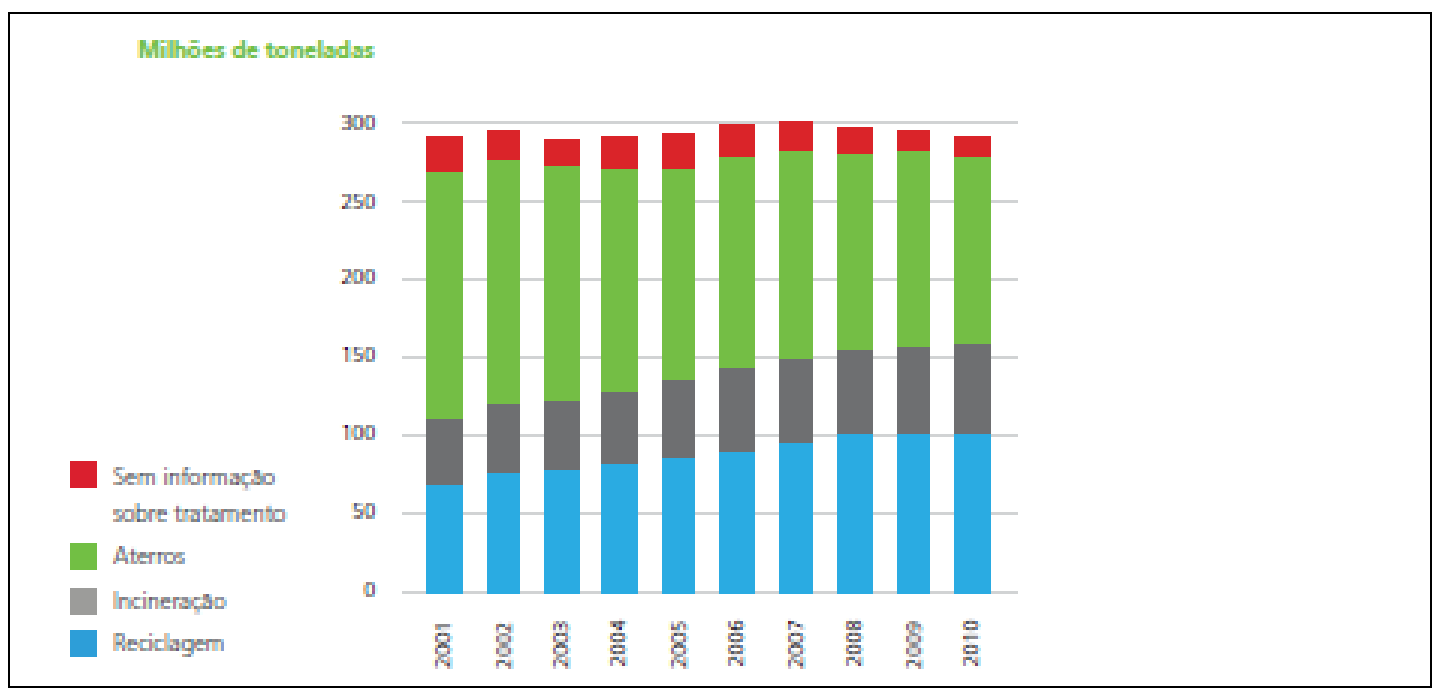

Figura 26 - Evolução do gerenciamento dos RSU em 32 países europeus - 2001/2010. Fonte: Lixão Zero, Ethos. 
Em 2013, a situação da destinação final dos RSU manteve-se praticamente inalterada em relação a 2012.

O volume destinado adequadamente apresentou pequena melhora em 2013 frente a 2012, porém a quantidade de RSU destinada inadequadamente cresceu em relação ao ano anterior, totalizando 28,8 milhões de toneladas que seguiram para lixões ou aterros controlados, que do ponto de vista ambiental pouco se diferenciam dos lixões, pois não possuem o conjunto de sistemas necessários para a proteção do meio ambiente e da saúde pública.(ABRELPLE, 2013).

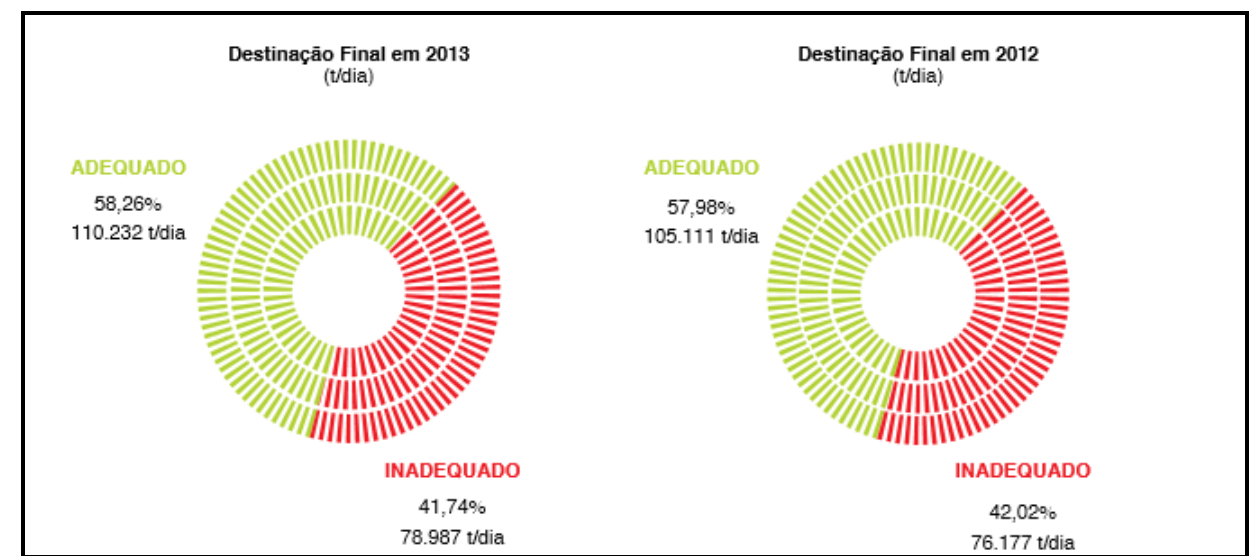

Figura 27 - Destinação final dos RSU coletados no Brasil.

Fonte: ABRELPE, 2013.

A Pesquisa Nacional de Saneamento Básico detalha um pouco mais as formas de destinação. Conforme mostra a Tabela 7. Tanto em 2000 quanto em 2008 observa-se que mais de $90 \%$ dos resíduos são destinados para a disposição final em aterros sanitários, aterros controlados e lixões, sendo os $10 \%$ restantes distribuídos entre unidades de compostagem, unidades de triagem e reciclagem, unidades de incineração, vazadouros em áreas alagadas e outros destinos.

\begin{tabular}{|c|c|c|c|c|}
\hline \multirow[b]{2}{*}{ DESTINO FINAL } & \multicolumn{2}{|l|}{2000} & \multicolumn{2}{|l|}{2008} \\
\hline & $\begin{array}{c}\text { Quantidade } \\
\text { (ton/dia) }\end{array}$ & $\%$ & $\begin{array}{c}\text { Quantidade } \\
\text { (ton/dia) }\end{array}$ & $\%$ \\
\hline Aterro Sanitário & $49.614,50$ & $35,4 \%$ & $110.044,40$ & $58,3 \%$ \\
\hline Aterro Controlado & $33.854,30$ & $24,2 \%$ & $36.673,20$ & $19,4 \%$ \\
\hline Vazadouros a céu aberto & $45.484,70$ & $32,5 \%$ & $37.360,80$ & $19,8 \%$ \\
\hline Unidades de Compostagem & $6.364,50$ & $4,5 \%$ & $1.519,50$ & $0,8 \%$ \\
\hline Unidade de triagem para reciclagem & $2.158,10$ & $1,5 \%$ & $2.592,00$ & $1,4 \%$ \\
\hline Unidade de incineração & 483,10 & $0,3 \%$ & 64,80 & $0,0 \%$ \\
\hline Vazadouro em áreas alagáveis & 228,10 & $0,2 \%$ & 35,00 & $0,0 \%$ \\
\hline Locais não fixos & 877,30 & $0,6 \%$ & \multicolumn{2}{|l|}{ não informado } \\
\hline Outros & $1.015,10$ & $0,7 \%$ & 525,20 & $0,3 \%$ \\
\hline Total & $140.079,70$ & $100,0 \%$ & $188.814,90$ & $100,0 \%$ \\
\hline
\end{tabular}

Tabela 7 - Destinação final de RSU - 2000 e 2008.

Fonte: Plano Nacional de Resíduos Sólidos, 2011. 
Neste relatório, pode-se avaliar também informações quanto à disposição final de resíduos e rejeitos no solo.

A Tabela mostra que, em termos quantitativos, de 2000 a 2008, houve um aumento de $120 \%$ na quantidade de resíduos e rejeitos dispostos em aterros sanitários e uma redução de $18 \%$ na quantidade encaminhada para lixões.

\begin{tabular}{|c|c|c|c|c|c|c|}
\hline \multirow{2}{*}{ PNSB } & \multicolumn{2}{|c|}{ LIXÃO } & \multicolumn{2}{|c|}{ ATERRO CONTROLADO } & \multicolumn{2}{|c|}{ ATERRO SANITÁRIO } \\
\hline & 2000 & 2008 & 2000 & 2008 & 2000 & 2008 \\
\hline BRASIL & $45.484,70$ & $37.360,80$ & $33.854,30$ & $36.673,20$ & $49.614,50$ & $110.044,40$ \\
\hline Pequenos Municípios & $34.533,10$ & $32.504,30$ & $10.405,90$ & $14.067,90$ & $6.878,40$ & $32.420,50$ \\
\hline Médios Municípios & $10.119,60$ & $4.844,50$ & $15.525,50$ & $17.278,30$ & $17.105,80$ & $45.203,40$ \\
\hline Grandes Municípios & 832,00 & 12,00 & $7.922,90$ & $5.327,00$ & $25.630,30$ & $32.420,50$ \\
\hline Região Norte & $6.148,50$ & $4.892,50$ & $3.221,80$ & $4.688,20$ & $1.350,20$ & $4.540,60$ \\
\hline Região Nordeste & $20.579,60$ & $23.461,50$ & $6.113,10$ & $6.819,00$ & $6.714,90$ & $25.246,60$ \\
\hline Região Sudeste & $11.521,00$ & $3.636,20$ & $15.685,60$ & $16.767,00$ & $32.568,40$ & $61.576,80$ \\
\hline Região Sul & $4.645,80$ & $1.432,80$ & $4.698,80$ & $3.485,00$ & $5.882,10$ & $15.293,10$ \\
\hline Região Centro Oeste & $2.589,80$ & $3.937,80$ & $4.135,00$ & $4.914,00$ & $3.098,90$ & $3.387,30$ \\
\hline
\end{tabular}

Tabela 8 - Principais destinações de RSU por tamanho de município - 2000, 2008.

Fonte: Plano Nacional de Resíduos Sólidos, 2011.

Percebe-se também a redução de resíduos destinados a unidades de compostagem e lixões em 2008 e aumento do volume destinado a aterros sanitários.

Diferentemente do que ocorria em 2000 , quando $60 \%$ da quantidade total dos resíduos e rejeitos urbanos eram dispostos de forma inadequada (aterro controlado e lixão), em 2008, vê-se a inversão desses valores, no qual $60 \%$ têm disposição final em aterro sanitário. Porém, não se pode esquecer que ainda há 74 mil toneladas por dia de resíduos e rejeitos sendo dispostos em aterros controlados e lixões.

\begin{tabular}{|c|c|c|c|}
\hline \multirow{2}{*}{ Ano } & \multicolumn{3}{|c|}{ Destino final dos residuos sólidos, por unidades de destino dos residuos (\%) } \\
\hline & Vazadouro a céu aberto & Aterro controlado & Aterro sanitário \\
\hline 1989 & & & 1,1 \\
\hline 2000 & & & 17,3 \\
\hline 2008 & & & 27,7 \\
\hline
\end{tabular}

Tabela 9 - Destino final de RSU no Brasil - 1989/2008.

Fonte: PNSB, 2008.

Desta forma, tal diagnóstico, datado de 2008, identificou a existência de 2.906 lixões no Brasil, distribuídos em 2.810 municípios. O panorama de Resíduos (ABRELPE, 2013), com informação mais atualizada, demonstra poucas mudanças no que diz respeito à destinação final dos RSU. 
Outra informação relevante é de que $98 \%$ dos lixões existentes concentram-se nos municípios de pequeno porte e $57 \%$ estão no nordeste. (Plano Nacional de Resíduos Sólidos, 2011).

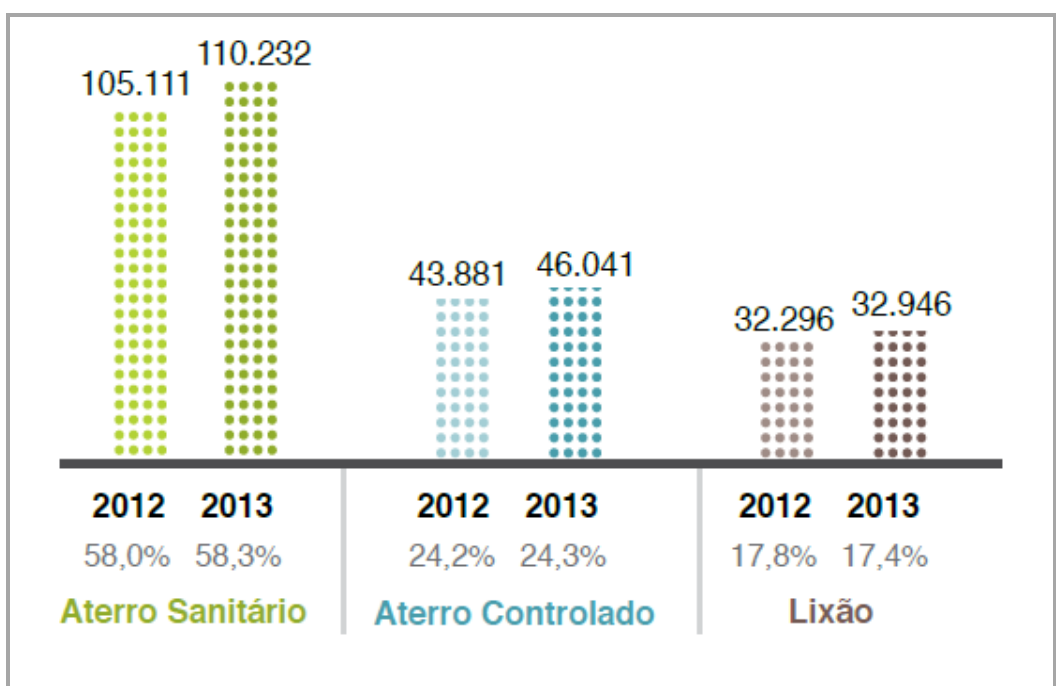

Figura 28 - Destinação final dos RSU coletados no Brasil - 2012, 2013 (ton/dia). Fonte: ABRELPE, 2013.

\begin{tabular}{|l|c|c|c|c|c|c|c}
\hline \multirow{2}{*}{ Destinação Final } & \multicolumn{7}{|c|}{2013 - Regiões e Brasil } \\
\hline & Norte & Nordeste & Centro-Oeste & Sudeste & Sul & BRASIL \\
\hline Aterro Sanitário & 92 & 453 & 161 & 817 & 703 & 2.226 \\
\hline Aterro Controlado & 111 & 504 & 148 & 645 & 367 & 1.775 \\
\hline Lixão & 247 & 837 & 158 & 206 & 121 & 1.569 \\
\hline BRASIL & $\mathbf{4 5 0}$ & $\mathbf{1 . 7 9 4}$ & $\mathbf{4 6 7}$ & $\mathbf{1 . 6 6 8}$ & $\mathbf{1 . 1 9 1}$ & $\mathbf{5 . 5 7 0}$
\end{tabular}

Tabela 10 - Quantidade de municípios brasileiros por destinação adotada - 2013. Fonte: ABRELPE, 2013.

No quesito tratamento, apesar da massa de resíduos sólidos urbanos apresentar alto percentual de matéria orgânica, as experiências de compostagem no Brasil são ainda incipientes.

O resíduo orgânico, por não ser coletado separadamente, acaba sendo encaminhado para disposição final, juntamente com os resíduos domiciliares. Essa forma de destinação gera, para a maioria dos municípios, despesas que poderiam ser evitadas caso a matéria orgânica fosse separada na fonte e encaminhada para um tratamento específico, por exemplo, via compostagem.

Do total estimado de resíduos orgânicos que são coletados $(94.335,1 \mathrm{t} / \mathrm{d})$ somente $1,6 \% \quad(1.509 \mathrm{t} / \mathrm{d})$ é encaminhado para tratamento via compostagem.

Em termos absolutos, tem-se 211 municípios brasileiros com unidades de compostagem, sendo que os Estados de Minas Gerais e Rio Grande do Sul possuem a maior concentração, 78 e 66 unidades respectivamente (PNRS, 2011). 
Outro ponto de extrema importância, fomentado pela Política Nacional de Resíduos Sólidos (2010) é a reciclagem, com resultados ainda muito inferiores às metas estabelecidas.

De acordo com o levantamento demonstrado na tabela, 2.592 ton/d seguem para a reciclagem, contra a geração de $58.527,4$ ton/d de itens recicláveis. Desta forma, somente $4 \%$ do resíduo potencialmente reciclável no país é aproveitado.

\begin{tabular}{|c|c|c|c|c|c|c|}
\hline Valor contratual médio & 2003 & 2004 & 2005 & 2006 & 2007 & 2008 \\
\hline $\begin{array}{l}\text { para disposição em } \\
\text { aterro sanitário }\end{array}$ & $\mathbf{R S} / \mathbf{t}$ & $R \$ / t$ & $\mathbf{R S} / \mathbf{t}$ & $\mathbf{R} \$ / \mathrm{t}$ & $\mathbf{R} \$ / \mathbf{t}$ & $\mathbf{R} \$ / \mathrm{t}$ \\
\hline Todas operadoras & 19,79 & 21,83 & 25,40 & 30,71 & 30,63 & 41,37 \\
\hline Empresa privada & 21,06 & 21,83 & 26,34 & 32,11 & 29,59 & 43,60 \\
\hline Prefeitura ou SLU & 16,63 & SI & 8,47 & 23,04 & 42,27 & 20,02 \\
\hline Consórcio & SI & SI & 15,85 & 17,25 & 37,27 & 46,16 \\
\hline Outro & SI & SI & SI & SI & 37,01 & 39,60 \\
\hline
\end{tabular}

Tabela 11 - Valor contratual médio para disposição de resíduos em aterro sanitário - 2003 a 2008.

Fonte: PNSB, 2008.

\subsubsection{Coleta de RSU}

Com relação ao serviço de coleta de RSU, houve um aumento de 4,4\% na quantidade em 2013 relativamente a 2012. A comparação deste índice com o crescimento da geração de RSU mostra uma discreta evolução na cobertura dos serviços de coleta, chegando a $90,4 \%$, com um total de 69.064.935 toneladas coletadas no ano (ABRELPE, 2013).

Por outro lado, a comparação entre a quantidade de RSU gerada e a coletada em 2013, mostra que diariamente mais de 20.000 toneladas deixaram de ser coletadas no país e, por consequência, tiveram destino impróprio (ABRELPE, 2013).

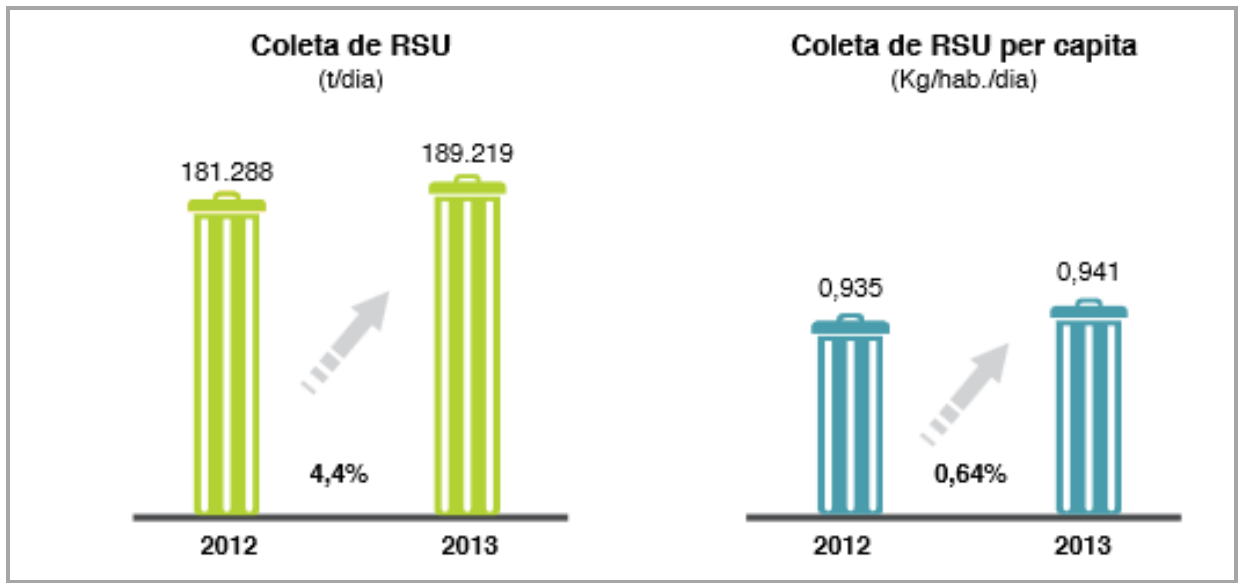

Figura 29 - Coleta de RSU total (ton/dia) e per capita - 2012 e 2013.

Fonte: ABRELPE, 2013. 
Existe grande variação deste indicador entre áreas urbanas e rurais. Enquanto na área urbana a coleta supera o índice de $98 \%$, a coleta em domicílios localizados em áreas rurais ainda não atinge $33 \%$.

As características das áreas em questão são diferenciadas. Desta forma, o modelo a ser adotado em comunidades rurais não deve ser exatamente igual à coleta urbana, porém avanços são necessários.

Tradicionalmente, os resíduos sólidos produzidos nas propriedades rurais são "tratados" e ou dispostos diretamente no solo, onde ocorre a degradação natural. Ao mesmo tempo, a parte não orgânica, que era gerada em pequenos volumes era reutilizada, transformando-as em utensílios domésticos ou para uso na atividade rural.

Porém o acesso aos bens industrializados, bem como eletro eletrônicos também tem apresentado grande incremento no ambiente rural, gerando maior volume de resíduos, alguns perigosos como baterias, lâmpadas fluorescentes, dentre outros.

As tabelas e figuras a seguir demonstram a variação do RSU coletado por região do Brasil, inclusive a evolução entre os anos 2000, 2008 e 2013.

Enquanto as Regiões Sul, Sudeste e Centro Oeste apresentam índices próximos de $95 \%$, o Nordeste e Norte ainda ficam próximos do patamar de $80 \%$ dos RSU coletados.

Cobertura da coleta direta e indireta de residuos sólidos

(Em \%)

\begin{tabular}{lccccccccc}
\hline & 2001 & 2002 & 2003 & 2004 & 2005 & 2006 & 2007 & 2008 & 2009 \\
\hline Brasil & 83,2 & 84,8 & 85,6 & 84,7 & 85,7 & 86,5 & 87,3 & 87,9 & 88,6 \\
Urbano & 94,9 & 95,9 & 96,5 & 96,3 & 97,0 & 97,4 & 97,9 & 98,1 & 98,5 \\
Rural & 15,7 & 18,6 & 20,5 & 21,6 & 23,9 & 26,0 & 28,4 & 30,2 & 32,7 \\
\hline Norte & 82,2 & 85,1 & 85,7 & 71,3 & 74,1 & 76,6 & 79,0 & 80,1 & 82,2 \\
Uribano & 85,3 & 88,1 & 88,6 & 88,9 & 91,6 & 93,5 & 95,2 & 95,7 & 97,1 \\
fural &.- & - & - & 17,0 & 19,2 & 20,6 & 23,3 & 24,9 & 29,4 \\
\hline Nordeste & 66,3 & 68,5 & 70,1 & 69,8 & 71,9 & 72,8 & 73,9 & 75,4 & 76,2 \\
Uribano & 88,4 & 90,3 & 91,8 & 90,8 & 92,8 & 93,3 & 94,3 & 95,3 & 95,8 \\
fural & 8,7 & 10,2 & 11,6 & 11,4 & 15,0 & 15,4 & 16,9 & 18,4 & 19,8 \\
\hline Sudeste & 92,3 & 93,6 & 93,9 & 94,2 & 94,4 & 94,8 & 95,3 & 95,3 & 95,9 \\
Uribano & 97,8 & 98,5 & 98,6 & 98,7 & 98,9 & 99,1 & 99,3 & 99,2 & 99,5 \\
Rural & 27,9 & 34,1 & 35,0 & 38,0 & 39,0 & 42,1 & 44,7 & 47,0 & 50,5 \\
\hline Sul & 84,4 & 85,4 & 86,7 & 87,3 & 87,9 & 89,3 & 90,5 & 90,7 & 91,5 \\
Uribano & 98,1 & 98,4 & 98,7 & 98,8 & 98,8 & 99,2 & 99,4 & 99,4 & 99,6 \\
Rural & 20,6 & 23,6 & 28,2 & 30,7 & 32,5 & 38,8 & 44,2 & 46,2 & 49,0 \\
\hline Centro-0este & 84,4 & 85,8 & 86,1 & 86,7 & 87,1 & 87,8 & 88,2 & 89,2 & 89,9 \\
Uribano & 95,7 & 96,7 & 97,5 & 97,4 & 98,1 & 98,7 & 98,6 & 98,9 & 98,8 \\
Rural & 11,4 & 13,5 & 15,4 & 20,4 & 19,6 & 19,5 & 21,7 & 21,8 & 26,4 \\
\hline
\end{tabular}

Tabela 12 - Cobertura da coleta direta e indireta de resíduos sólidos - 2001 a 2009. Fonte: IPEA, 2012. 


\begin{tabular}{l|c|c|c|}
\hline \multirow{2}{*}{ Regioes } & \multicolumn{1}{|c|}{2012} & \multicolumn{2}{|c|}{2013} \\
\hline Norte & $\begin{array}{c}\text { RSU Coletado (t/dia) } / \\
\text { Indice (Kg/hab./dia) }\end{array}$ & $\begin{array}{c}\text { RSU Coletado } \\
\text { (t/dia) }\end{array}$ & $\begin{array}{c}\text { Indice } \\
\text { (Kg/hab./dia) }\end{array}$ \\
\hline Nordeste & $11.585 / 0,709$ & 12.178 & 0,716 \\
\hline Centro-Oeste & $40.021 / 0,742$ & 41.820 & 0,750 \\
\hline Sudeste & $14.788 / 1,025$ & 15.480 & 1,032 \\
\hline Sul & $95.142 / 1,166$ & 99.119 & 1,173 \\
\hline BRASIL & $19.752 / 0,712$ & 20.622 & 0,716 \\
\hline
\end{tabular}

Tabela 13 - Índice per capita de Coleta de RSU - 2012, 2013.

Fonte: ABRELPE, 2013.

\begin{tabular}{|lcccc|}
\hline Unidade de análise & \multicolumn{2}{c}{$\begin{array}{c}\text { Quantidade de resíduos coletados } \\
\text { (t/dia) }\end{array}$} & \multicolumn{2}{c|}{$\begin{array}{c}\text { Quantidade de resíduos por } \\
\text { habitante urbano (kg/hab.dia) }\end{array}$} \\
Brasil & $\mathbf{2 0 0 0}$ & $\mathbf{2 0 0 8}$ & $\mathbf{2 0 0 0}$ & $\mathbf{2 0 0 8}$ \\
Norte & $149.094,30$ & $183.481,50$ & 1,1 & 1,1 \\
Nordeste & $10.991,40$ & $14.637,30$ & 1,2 & 1,3 \\
Sudeste & $37.507,40$ & $47.203,80$ & 1,1 & 1,2 \\
Sul & $74.094,00$ & $68.179,10$ & 1,1 & 0,9 \\
Centro-Oeste & $18.006,20$ & $37.342,10$ & 0,9 & 1,6 \\
\end{tabular}

Tabela 14 - Quantidade de RSU coletados por região do Brasil - 2000, 2008. Fonte: Plano Nacional de Resíduos Sólidos, 2011.

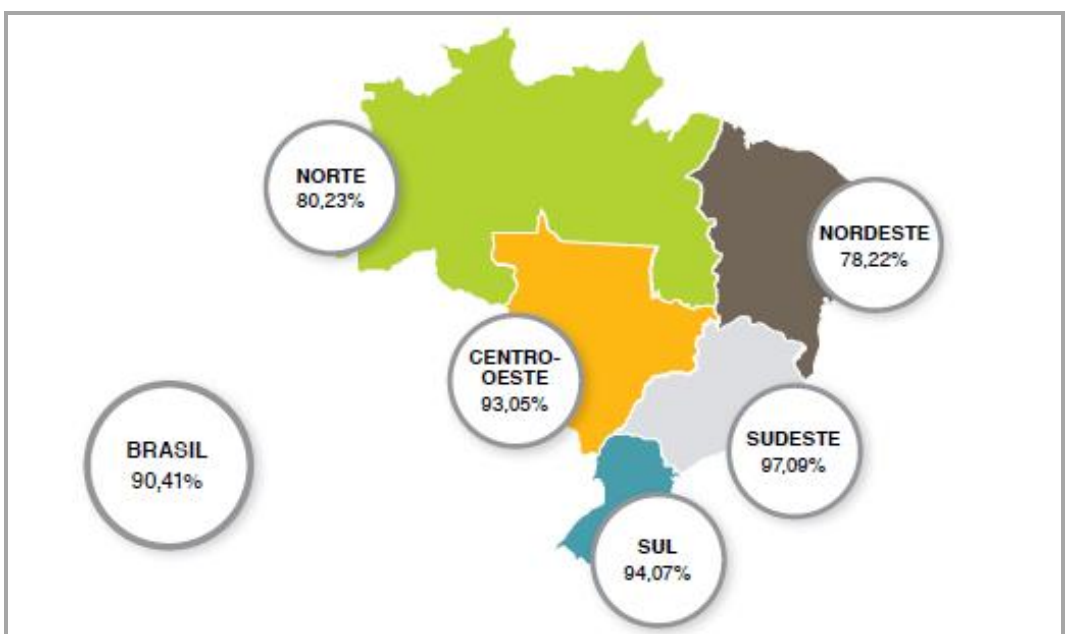

Figura 30 - Índice de abrangência da Coleta de RSU total (\%) por região - 2013. Fonte: ABRELPE, 2013.

Com relação a custos envolvidos, o gasto médio brasileiro para o gerenciamento de resíduos é de $\mathrm{R} \$ 70,00$ por habitante, conforme apresentado pelo Plano Nacional de Resíduos Sólidos (2012).

O relatório da Abrelpe (2013) detalha o custo para a coleta de resíduos por região, conforme Tabela16. 


\begin{tabular}{|c|c|c|c|c|}
\hline \multirow[b]{2}{*}{ Regiøes } & \multirow{2}{*}{$\begin{array}{c}2012 \\
\text { Recursos Aplicados } \\
\text { Coleta RSU / Equival. } \\
\text { por Habitante } \\
\text { (Rs milhoes/ano)/ } \\
\text { (R\$/mes) }\end{array}$} & \multicolumn{3}{|c|}{2013} \\
\hline & & $\begin{array}{l}\text { Populaçâo } \\
\text { Total }\end{array}$ & $\begin{array}{c}\text { Recursos } \\
\text { Aplicados na } \\
\text { Coleta RSU } \\
\text { (R\$ milhoes/ano) }\end{array}$ & $\begin{array}{l}\text { Valor Equivalente } \\
\text { por Habitante } \\
\text { (R:\$ / mes) }\end{array}$ \\
\hline Norte & $608 / 3,09$ & 17.013 .559 & 636 & 3,11 \\
\hline Nordeste & $1.708 / 2,64$ & 55.794 .707 & 1.864 & 2,78 \\
\hline Centro-Oeste & $511 / 2,95$ & 14.993.191 & 544 & 3,02 \\
\hline Sudeste & $4.245 / 4,33$ & 84.465 .570 & 4.541 & 4,48 \\
\hline Sul & $1.095 / 3,29$ & 28.795 .762 & 1.179 & 3,41 \\
\hline BRASIL & $8.167 / 3,50$ & 201.062 .789 & 8.764 & 3,63 \\
\hline
\end{tabular}

Tabela 15 - Recursos Aplicados na Coleta de RSU - 2012, 2013.

Fonte: ABRELPE, 2013.

Um fator comparativo importante é a proporção de gastos na Gestão de Resíduos sobre o PIB per capita, conforme estudo da ISWA (2010).

Este fator divide o orçamento total para a gestão de resíduos pela população e em seguida expressa como uma percentagem do PIB per capita.

A maior parte dos gastos de gestão de resíduos das cidades do mundo está entre 0,1 a $0,7 \%$ do $\mathrm{PIB} /$ per capita. Considera-se o gasto de $0,3 \%$ a $0,5 \%$ um gasto sustentável para este processo.

Países em desenvolvimento podem apresentar indicador próximo ao de desenvolvidos, porém com diferença representativa no valor absoluto. Importante citar que estes países normalmente gastam mais da metade do orçamento apenas na coleta (mão de obra e combustível), embora esta taxa continue baixa e o transporte de resíduos ineficiente.

Se compararmos o gasto médio de $70 \mathrm{R} \$$ /hab conforme o Plano Nacional de Resíduos Sólidos e o PIB per capita de $R \$ 24.000,00$, temos 0 percentual de $0,3 \%$ para o Brasil, considerado dentro da faixa de gastos sustentáveis.

\subsubsection{Coleta seletiva}

Neste capítulo será abordado o potencial de reciclagem brasileiro, apresentando a composição gravimétrica dos RSU e a situação atual da coleta seletiva.

Conforme apresentado anteriormente (PNRS, 2011), a composição dos RSU brasileiros é separada por $51,4 \%$ de matéria orgânica, 31,9\% de materiais recicláveis e o restante formado por diversos materiais.

Tal perfil é característico de países de baixa renda, conforme mostra estudo do Banco Mundial (2012) na Figura 31. 


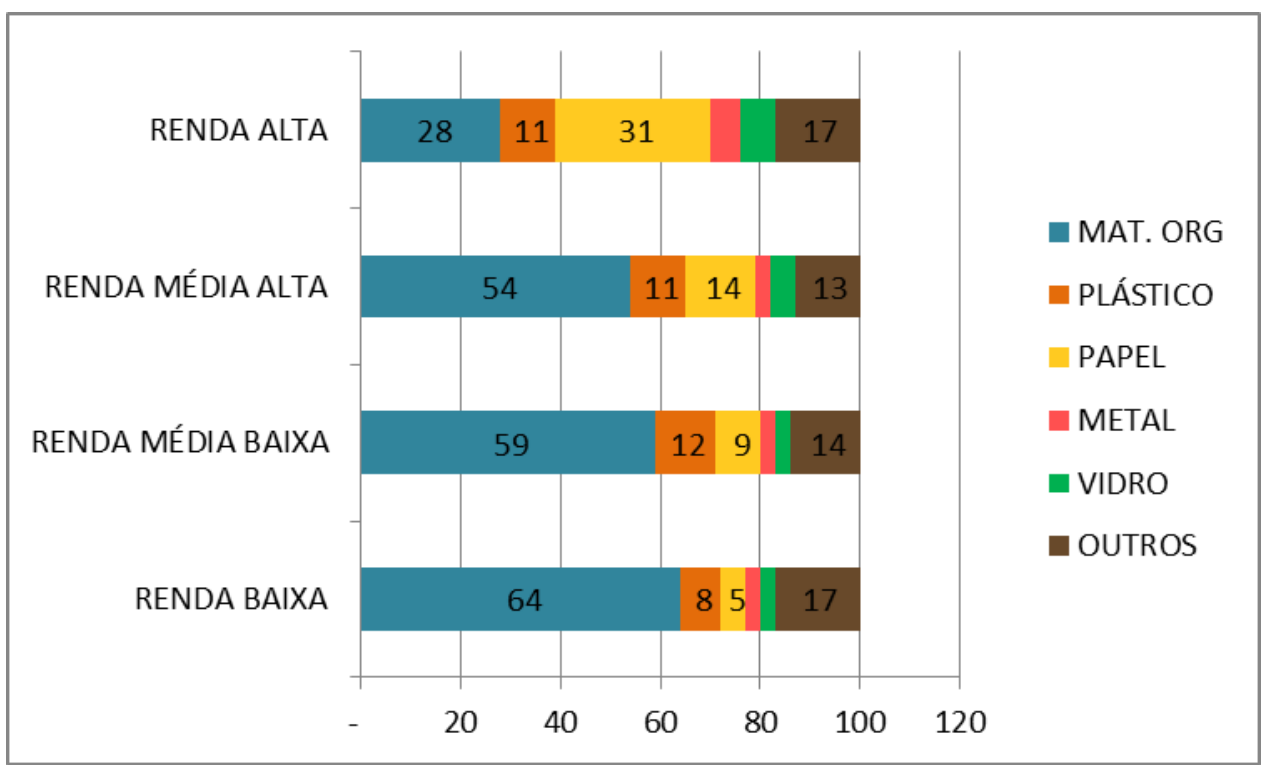

Figura 31 - Composição gravimétrica média de países de acordo com a renda. Fonte: Adaptado de BANCO MUNDIAL, 2012.

Avaliando-se somente a fração seca do lixo, o consumo aparente de embalagens apresentado pelo PNRS (2011), mostra a representatividade do papel e plástico neste mercado.

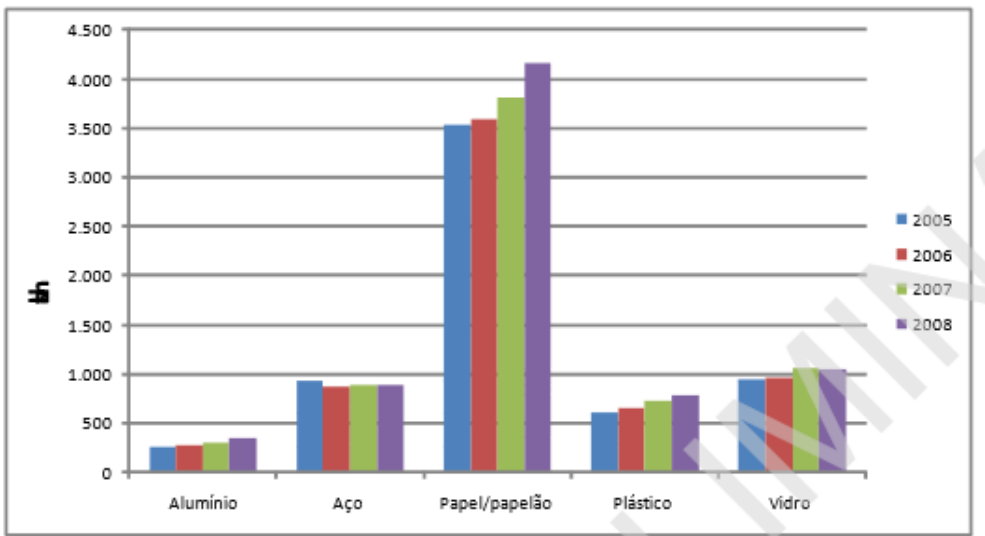

Figura 32 - Consumo aparente de embalagens Brasil - 2005 a 2008.

Fonte: Plano Nacional de Resíduos Sólidos, 2011

A partir desta composição, é possível dimensionar a oportunidade de crescimento do mercado de coleta seletiva, instrumento da Política Nacional de Resíduos Sólidos (2010).

De acordo com o Plano Nacional de Resíduos Sólidos (2011), houve um aumento de $120 \%$ no número de municípios que desenvolveram tais programas entre 2000 e 2008, que chegaram a 994, estando a maioria localizada nas regiões Sul e Sudeste.

Esse marco embora importante, ainda não ultrapassa 18\% dos municípios brasileiros. E ainda assim os programas são precários, sem abrangência de toda a cidade.

Estimativas a partir das informações disponíveis pelo SNIS, indicam que a participação dos resíduos recuperados pelos programas de coleta seletiva 
formais ainda é muito pequena, o que sugere que a reciclagem no país ainda é mantida pela reciclagem pré-consumo e pela coleta pós-consumo informal, que devem ser objeto de estudos específicos (Plano Nacional de Resíduos Sólidos, 2011).

Importante colocar também que parte dos resíduos recicláveis é coletado por catadores não formais. Este volume ainda é de difícil apuração e portanto não considerado no volume recuperado a partir de programas oficiais. A Tabela 16 exemplifica com clareza a contribuição dos resíduos da coleta seletiva frente ao volume reciclado.

\begin{tabular}{|c|c|c|c|}
\hline Residuos & $\begin{array}{c}\text { Qtde de } \\
\text { residuos } \\
\text { reciclados no } \\
\text { país } \\
\text { (mil ton/ano) }\end{array}$ & $\begin{array}{l}\text { Qtde recuperada } \\
\text { por programas } \\
\text { oficiais de coleta } \\
\text { seletiva } \\
\text { (mil ton/ano) }\end{array}$ & $\begin{array}{l}\text { Participação da } \\
\text { coleta seletiva } \\
\text { formal na } \\
\text { reciclagem total }\end{array}$ \\
\hline Metais & $9.817,8$ & 72,3 & $0,7 \%$ \\
\hline Papel/papelão & $3.827,9$ & 285,7 & $7,5 \%$ \\
\hline Plástico & $962,0^{*}$ & 170,3 & $17,7 \%$ \\
\hline Vidro & 489,0 & 50,9 & $10,4 \%$ \\
\hline
\end{tabular}

*Dado de 2007

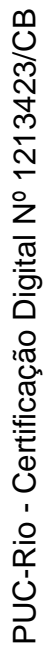

Tabela 16 - Estimativa da participação dos programas de coleta seletiva formal - 2008.

Fonte: Plano Nacional de Resíduos Sólidos, 2011.

Mesmo após a publicação da Lei 12.305/2010 e seus desdobramentos estaduais e municipais, em 2013, pouco mais de $62 \%$ dos municípios registraram alguma iniciativa de coleta seletiva, conforme mostra a Figura abaixo.

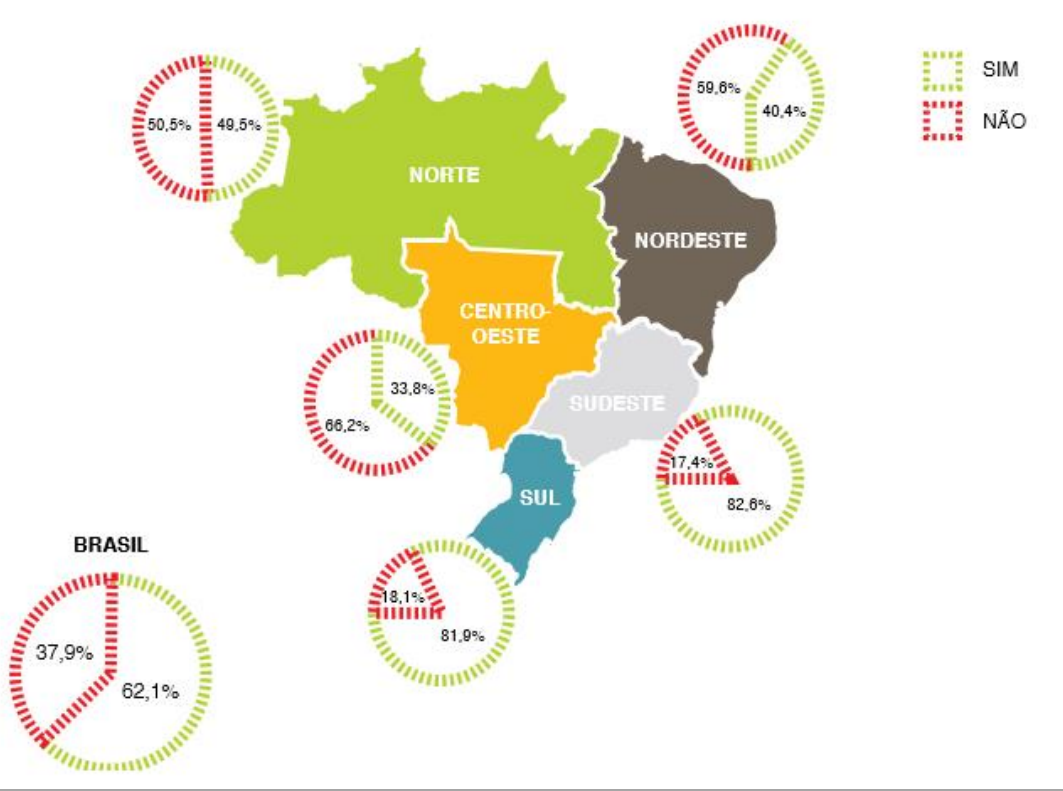

Figura 33 - Iniciativas de coleta seletiva nos municípios em 2013. Fonte: ABRELPE, 2013. 


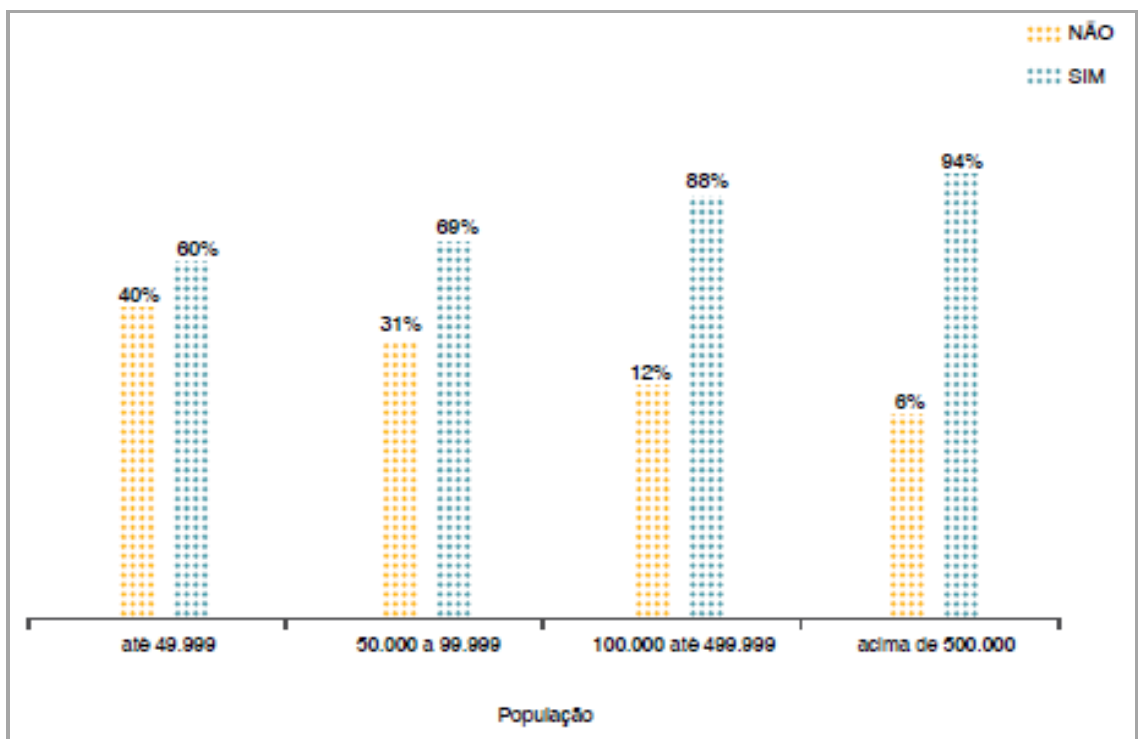

Figura 34 - Iniciativas de coleta seletiva por grupos de municípios.

Fonte: ABRELPE, 2013.

Embora seja expressiva a quantidade de municípios com iniciativas de coleta seletiva, é importante comentar que muitas vezes estas atividades resumem-se ao atendimento em algumas ruas da cidade ou somente à disponibilização de pontos de entrega voluntária ou convênios com cooperativas de catadores, que não abrangem a totalidade do território ou da população do município. (ABRELPE, 2013).

Distribuição da Coleta Seletiva por Região

\begin{tabular}{|c|c|c|c|c|c|c|c|c|}
\hline \multirow{2}{*}{$\begin{array}{c}\text { Unidade de } \\
\text { Análise }\end{array}$} & \multicolumn{2}{|c|}{ Municipios com coleta seletiva } & \multicolumn{2}{|c|}{ Todo Município (\%) } & \multicolumn{2}{|c|}{ Somente sede municipal } & \multicolumn{2}{|c|}{ Outras áreas (\%) } \\
\hline & 2000 & 2008 & 2000 & 2008 & 2000 & 2008 & 2000 & 2008 \\
\hline Brasil & 451 & 994 & 39 & 38 & 29 & 41 & 32 & 21 \\
\hline Norte & 1 & 21 & 0 & 5 & 0 & 48 & 100 & 48 \\
\hline Nordeste & 27 & 80 & 19 & 38 & 33 & 30 & 48 & 33 \\
\hline Sudeste & 140 & 408 & 38 & 32 & 18 & 42 & 44 & 26 \\
\hline Sul & 274 & 454 & 42 & 46 & 34 & 20 & 23 & 34 \\
\hline Centro Oeste & 9 & 31 & 44 & 16 & 22 & 48 & 33 & 35 \\
\hline
\end{tabular}

Tabela 17 - Distribuição da coleta seletiva por região - 2000, 2008.

Fonte: Plano Nacional de Resíduos Sólidos, 2011.

Estimativa da quantidade de material recuperado por programas de coleta seletiva

\begin{tabular}{|c|c|c|c|c|c|c|}
\hline \multirow{2}{*}{ Unidade de Análise } & \multirow{2}{*}{$\begin{array}{l}\text { Municipios com } \\
\text { coleta seletiva }\end{array}$} & \multirow{2}{*}{$\begin{array}{l}\text { Pop. urbana } \\
\text { Núm. Hab. }\end{array}$} & Papel & Plástico & Metais & Vidro \\
\hline & & & \multicolumn{4}{|c|}{$1 \mathrm{mil}$ ton/ano } \\
\hline Brasil & 994 & $\begin{array}{l}77.708 .739 \\
0\end{array}$ & 285,7 & 170,3 & 72,3 & 50,9 \\
\hline Municipios pequenos & 862 & 14.951 .052 & 71,6 & 43,6 & 22,2 & 13,8 \\
\hline Municipios médios & 120 & 31.308 .914 & 166,6 & 92,4 & 36,9 & 23,7 \\
\hline Municipios grandes & 12 & 31.448 .773 & 47,6 & 34,3 & 13,2 & 13,3 \\
\hline
\end{tabular}

Tabela 18 - Quantidade de material recuperado por programadas de coleta seletiva - 2008

Fonte: Plano Nacional de Resíduos Sólidos, 2011.

O relatório divulgado pelo Cempre (2012) também reafirma este fato: apenas 766 municípios brasileiros (14\%) oferecem serviço de coleta seletiva. Este número representa 27 milhões de pessoas, $12 \%$ da população brasileira. 
Neste contexto, é importante destacar que em $62 \%$ destas cidades, as cooperativas de catadores de lixo fazem parte da coleta seletiva, em $26 \%$ das cidades as empresas particulares e em $52 \%$ destas somente a prefeitura é responsável pela coleta seletiva.

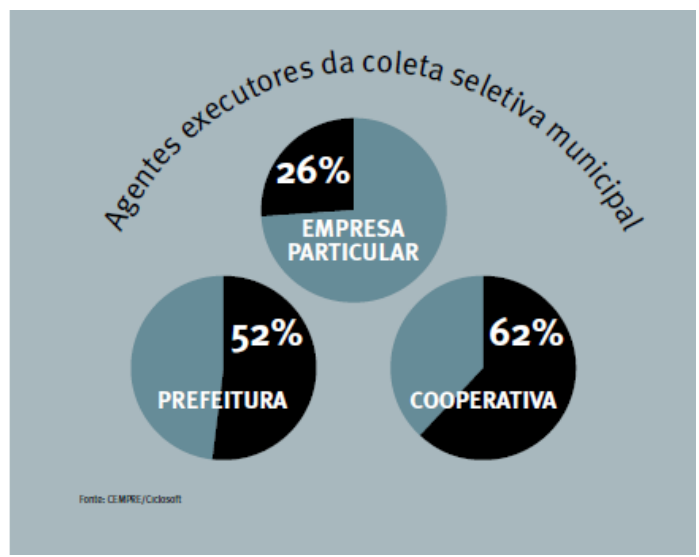

Figura 35 - Agentes executores da coleta seletiva municipal. Fonte: CEMPRE, 2012.

A PNSB não apresenta dados sobre os métodos ou custos dos sistemas de coleta seletiva. O relatório do IPEA (2013), através da consulta de outras fontes, buscou chegar num panorama aproximado. A pesquisa de 2008 do SNIS foi aplicada a 372 municípios, dos quais 111 afirmaram possuir algum tipo de sistema de coleta seletiva, conforme tabela abaixo.

\begin{tabular}{|c|c|c|c|}
\hline \multicolumn{4}{|c|}{ Caracterização de sistemas de coleta seletiva (2008) } \\
\hline Modalidade & Ag. Publico/empresa contratada & Org. Catadores & Outros Agentes \\
\hline Porta a Porta & 82 & 82 & 3 \\
\hline PEV's & 39 & & 4 \\
\hline Outros & 19 & 2 & \\
\hline
\end{tabular}

Tabela 19 - Caracterização de sistemas de coleta seletiva - 2008.

Fonte: Plano Nacional de Resíduos Sólidos, 2011.

A leitura desta tabela deve considerar que as opções não são mutuamente exclusivas. Por exemplo, nesta amostra todos os sistemas de coleta porta a porta eram realizados ao mesmo tempo por agentes públicos e por organizações de catadores.

Da mesma forma, muitas das prefeituras que realizavam coleta porta a porta também possuíam a infraestrutura para coleta por meio de postos de entrega voluntária (PEVs).

Ainda sobre coleta seletiva, é importante avaliar-se o custo envolvido. De acordo com estudos do Cempre (2012), o custo da operação mostra-se 4,5 vezes superior ao da coleta convencional, principalmente pela forma como a maioria dos municípios a aplica: a coleta porta a porta. 


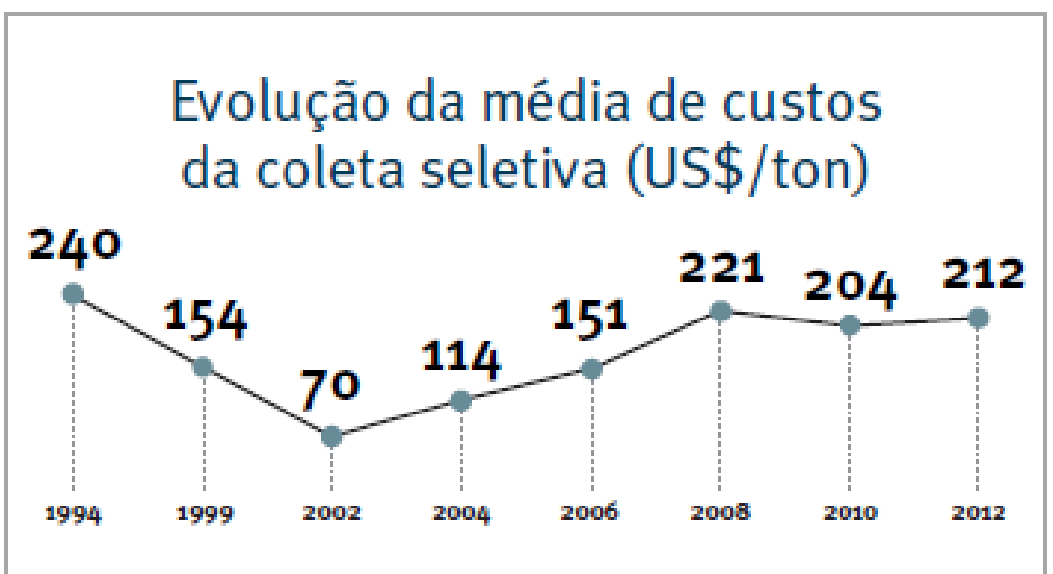

Figura 36 - Evolução média de custos da coleta seletiva - 1994 a 2012. Fonte: CEMPRE, 2012.

Este tipo de coleta, separada do processo de coleta dos RSU, implica em, por exemplo, investimentos para a compra de veículos para executarem a mesma rota dos destinados aos RSU. Como tais resíduos são mais leves e ocupam mais espaço, estima-se que este investimento precisaria ser ainda maior que o aplicado à coleta convencional para abrangência de todos os domicílios.

Segundo informações durante entrevistas à Diretoria de Serviços Especiais e Ambientais da Comlurb (2014), como existem poucas rotas definidas e horários mais restritos à coleta para otimização do custo logístico, o engajamento da população é baixo, reduzindo ainda mais a rentabilidade do negócio.

Ainda segundo entrevistas, o volume total coletado ainda é prejudicado por catadores não organizados, que realizam a coleta nos domicílios momentos antes da passagem dos veículos contratados pelo governo, reduzindo ainda mais o volume e consequentemente a viabilidade do projeto.

Alguns municípios buscam reduzir custos logísticos com a inclusão de PEV's e containers coletores, porém tais fatores também dependem do engajamento da população, bem como a resolução da coleta antecipada por catadores não cadastrados, conforme comentado no parágrafo acima.

Desta forma, pode-se concluir que os resultados esperados na PNRS (2010) que dizem respeito à prioridade de utilização de resíduos, redução do volume enviado para aterro, incentivo à reciclagem e compostagem demandarão muito mais tempo para dar resultado do que o previsto.

A Alemanha, um dos países pioneiros em ações da GIRSU, publicou sua primeira lei na década de 90 . Nesta época, somente $5 \%$ do lixo era recuperado ou reciclado, $30 \%$ era incinerado e $65 \%$ seguia para aterros.

A preocupação da população com a destinação de seus resíduos existia antes mesmo da publicação das leis. Somente $2 \%$ da população considerava a incineração como a melhor solução e $2 \%$ eram a favor de 
aterros sanitários. O Partido Verde e o Green Peace da Alemanha foram fundados na década de 80.

Mesmo com o engajamento da população, dos poderes públicos e privados, somente em 10 anos o país passou a conviver com resultados significativos, baseados na coleta seletiva e responsabilidade compartilhada com produtores e geradores de resíduos (SASSE, 2002).

O Brasil não apresenta o mesmo nível de engajamento social, público e privado da Alemanha. Para que a coleta seletiva se mantenha como o principal instrumento da PNRS (2010) para o cumprimento das metas, é preciso repensar no prazo de atendimento destas, buscar alternativas complementares para a separação de resíduos, direcionar investimentos e esforços para este foco, bem como investir pesadamente em conscientização populacional.

\subsubsection{Catadores}

A gestão de resíduos brasileira, principalmente no que tange à sua coleta, sempre esteve diretamente ligada aos catadores. Sem estes agentes, os números alcançados com a reciclagem de latinhas e papéis não teriam sido alcançados.

Tal resultado não foi obtido com planejamento governamental e sim através de muito esforço destes agentes. A grave crise social do país que apresenta uma das piores distribuições de renda do mundo - e o aumento do valor de mercado dos resíduos recicláveis, tem levado um número cada vez maior de pessoas a buscar a sua sobrevivência através da catação, existentes no lixo domiciliar. Os catadores trabalham nas ruas, vazadouros e aterros de lixo ainda existentes no Brasil (Bastos, 2012).

Por mais insalubre que tal atividade possa ser, trazendo graves riscos à saúde, o processo pode gerar uma remuneração representativa. Durante a operação do Aterro de Gramacho, por exemplo, a remuneração para cada catador poderia chegar a até $R \$ 4.000,00$ mensais. Na estrutura anterior deste aterro, cada catador era responsável por seu exclusivo rendimento, trabalhando em horários de sua exclusiva responsabilidade, características convidativas para moradores de rua, pessoas que se encontram à margem da sociedade, muitas vezes dependentes químicos (BASTOS, 2005).

A publicação da Política Nacional dos Resíduos Sólidos (Lei 12.305/2010) foi um marco para os catadores. Por um lado, a lei obriga o fechamento de vazadouros, impedindo o trabalho dos catadores na forma habitualmente conhecida e de prática destas pessoas, reduzindo as possibilidades de ganho.

Por outro, tanto a Política como o Plano Nacional de Resíduos Sólidos e os decorrentes decretos e Planos Municipais, prevêem envolvimento com 
as cooperativas de catadores. A PNRS inclui formalmente os catadores, incentiva a organização em cooperativas e os elege como instrumentos para cumprimentos de metas estabelecidas.

Com a publicação da Política, foram destinados de mais de 280 milhões de reais para ações voltadas aos catadores de materiais recicláveis entre 2003 e 2010. (Plano Nacional de Resíduos Sólidos, 2011).

As principais vantagens da utilização de cooperativas de catadores são a geração de emprego formal e renda, o resgate da cidadania dos catadores, a redução das despesas com os programas de reciclagem, já que parte dos custos com estes programas podem ser repassados às cooperativas. Além disso, o custo de mão de obra é baixo.

Como desvantagem neste processo, podemos apresentar a baixa escolaridade dos catadores para busca da lucratividade da operação (conhecimento em gestão, logística, operação, comércio, manutenção de equipamentos, dentre outros), já que a maioria dos estados e municípios coloca a responsabilidade do negócio às cooperativas.

Além disso, o manejo de resíduos sólidos é uma atividade que apresenta riscos à saúde, se não controlada corretamente.

A mudança nas gestões municipais também é um problema encontrado nesta atividade, pelo mesmo motivo abordado no capítulo que aborda a coleta seletiva: o abandono ou a diminuição de investimento nos programas devido a interesses políticos de diferentes grupos desestimula a formação de uma boa equipe, fato que necessita de ações de médio prazo.

Além dos pontos acima, o incentivo ao desenvolvimento e apoio às cooperativas de catadores, descrito tanto na Política, quanto no Plano Nacional de Resíduos Sólidos transformou-se terceirização do serviço, sob a ótica dos gestores de estados e municípios.

De acordo com entrevistas e pesquisas de campo realizadas, conforme detalhadas nos apêndices 6.1 e 6.4, a maioria das prefeituras têm simplesmente repassado a responsabilidade do processamento dos resíduos originados da coleta seletiva, cedendo somente o local e equipamentos - muitas vezes, precários - às cooperativas, oferecendo baixa estrutura para gestão de negócios.

Segue abaixo a visão geral de resíduos, apresentada pelo CEMPRE (2012). 


\begin{tabular}{|c|c|}
\hline Populaçāo urbana (IBGE) (mil habitantes) & 165.018 \\
\hline Número de cooperathas & 1.175 \\
\hline Número de catadores em cooperativas & 30.390 \\
\hline Total de residuos sólidos coletados (ton/dia) & 173.703 \\
\hline Fraçāo seca reciclóvel (\% total) & $31,9 \%$ \\
\hline Fraçāo molhada e outros (\% total) & $68,1 \%$ \\
\hline Triagem/Recuperaçāo (fraçāo seca) (ton/dia) & 14.909 \\
\hline Cooperativas & 2.329 \\
\hline Outros canais de triagem & 12.580 \\
\hline Percentual de triagem/Recuperaçāo total & $26,9 \%$ \\
\hline
\end{tabular}

Figura 37 - Visão geral da reciclagem brasleira. Fonte: CEMPRE, 2012.

\subsubsection{Reciclagem}

Mesmo com baixo envolvimento político, privado e populacional, os resultados obtidos no mercado de reciclagem, principalmente se separados em alguns tipos de materiais são referência mundial.

O Brasil dá passos importantes para ocupar posição de destaque no cenário global da reciclagem. Isso se deve não apenas aos índices alcançados de retorno de embalagens, a exemplo das latas de alumínio e das garrafas PET.

O potencial do setor é proporcional ao desenvolvimento econômico, aos avanços nas práticas de sustentabilidade das empresas, a algumas ações de governo bem construídas e melhorias na conscientização por parte do consumidor. A tendência é uma aceleração deste crescimento à medida que a Política Nacional de Resíduos Sólidos for colocada em prática, dentro de um ambiente regulatório, favorável a novos investimentos.

Em um país como o Brasil, medir a reciclagem é um trabalho complexo por vários motivos: o grau de informalidade do mercado, a inexistência de dados oficiais consistentes e abrangentes, a dimensão territorial e suas diferentes realidades, e a diversidade de participantes do mercado catadores, atacadistas de materiais recicláveis, indústrias recicladoras de pequeno, médio e grande porte, prefeituras, empresas de coleta, entre outros - dificultam a busca de informações. (CEMPRE, 2012).

Estudos do Ipea (2012) projetam que o país perde $R \$ 8$ bilhões de reais anualmente com o descarte incorreto de resíduos que poderiam ser reaproveitados. Por sua vez, o CEMPRE aponta que em 2012 a coleta, triagem e o processamento dos materiais em indústrias recicladoras geraram um faturamento de mais de $R \$ 10$ bilhões. 
Além dos ganhos ambientais e sociais, o reaproveitamento de materiais também gera vantagens financeiras: dados do Ipea (2012) indicam que a substituição de celulose por fibras recicladas permite a economia de $331 \mathrm{R} \$ /$ ton, metade do custo, sem utilização da matéria prima originada do processo de reciclagem ( $\mathrm{R} \$ 687$ por tonelada). No caso do alumínio, o valor cai de $R \$ 6,1$ mil para $R \$ 3,4$ mil por tonelada.

Visto a importância da recuperação das embalagens pós-consumo e sua reinserção na cadeia de produção, projeções demonstradas no CEMPRE Review 2013, considerando o aumento de $20 \%$ da taxa de recuperação de resíduos recicláveis entre 2010 e 2014, apontam para uma redução média de $10,4 \%$ nos preços da matéria-prima reciclada.

Com incentivos fiscais e creditícios do governo, a reciclagem poderia elevar em até $31,5 \%$ a renda gerada pela coleta, triagem e materiais de recicláveis. Ainda que haja diversos incentivos do governo neste processo, a estrutura fiscal precisa ser revisada. Há bitributação na cadeia da reciclagem, que certamente desestimula o crescimento do mercado (CEMPRE Review, 2013).

Os dados divulgados pela Cempre (2013), a partir de projeções com base em dados públicos do IPEA (Instituto de Pesquisa Econômica Aplicada) e de associações empresariais mostram que $27 \%$ dos resíduos recicláveis (fração seca) coletados nas cidades foram efetivamente recuperados, retornando à atividade produtiva. No caso específico das embalagens, o índice de recuperação foi de $65,3 \%$.

\begin{tabular}{|c|c|c|c|c|c|}
\hline \multirow[b]{2}{*}{ Material } & \multicolumn{3}{|c|}{ Benefício econômico por dia } & \multirow[b]{2}{*}{$\begin{array}{l}\text { Custo } \\
\text { adicional da } \\
\text { reciclagem } \\
\text { (RS/ton) }\end{array}$} & \multirow[b]{2}{*}{$\begin{array}{c}\text { Benefício } \\
\text { total } \\
\text { (RS/ dia) }\end{array}$} \\
\hline & $\begin{array}{l}\text { Reciclagem } \\
\text { incremental } \\
\text { (ton/dia) }\end{array}$ & Insumos (RS) & $\begin{array}{c}\text { Ambiental } \\
\left(\mathrm{CO}_{2} \text {, energia e }\right. \\
\text { biodiversidade) } \\
\text { (RS) }\end{array}$ & & \\
\hline Aço & 253 & 32.164 & 18.741 & 113 & 22.287 \\
\hline Alumínio & 61 & 164.496 & 20.539 & 113 & 178.189 \\
\hline Celulose & 1.397 & 460.854 & 33.517 & 113 & 336.563 \\
\hline Plástico & 554 & 644.545 & 31.009 & 113 & 612.982 \\
\hline Vidro & 246 & 29.572 & 2.711 & 113 & 4.436 \\
\hline Total & 2.511 & 1.331 .632 & 106.517 & & 1.154 .457 \\
\hline
\end{tabular}

Tabela 20 - Benefícios econômicos da reciclagem. Fonte: CEMPRE, 2012. 


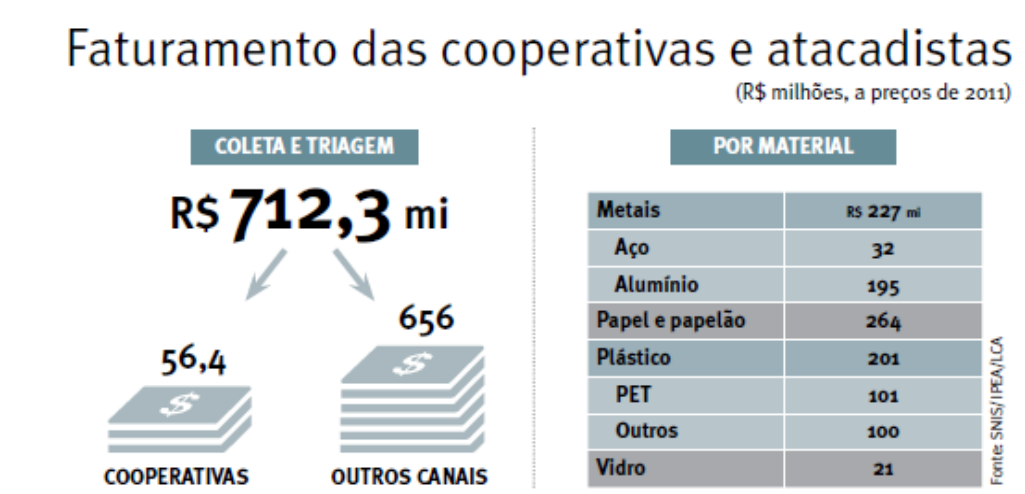

Figura 38 - Faturamento das cooperativas e atacadistas - 2011.

Fonte: CEMPRE, 2012.

O Brasil é líder mundial de recuperação de latas de alumínio, consequência - entre outros fatores - do preço atrativo da sucata, que acompanha os valores da commodity no mercado internacional.

A reciclagem de garrafas PET é crescente, impulsionada pelo consumo de fibras sintéticas pelo setor têxtil e outras aplicações que se diversificam.

Nos últimos dez anos, a taxa de recuperação do material aumentou de $32,9 \%$ para $57,1 \%$, totalizando um mercado anual de $R \$ 1$ bilhão. Em 2012 existiam no país 93 indústrias recicladoras com mais de cinco anos de existência.

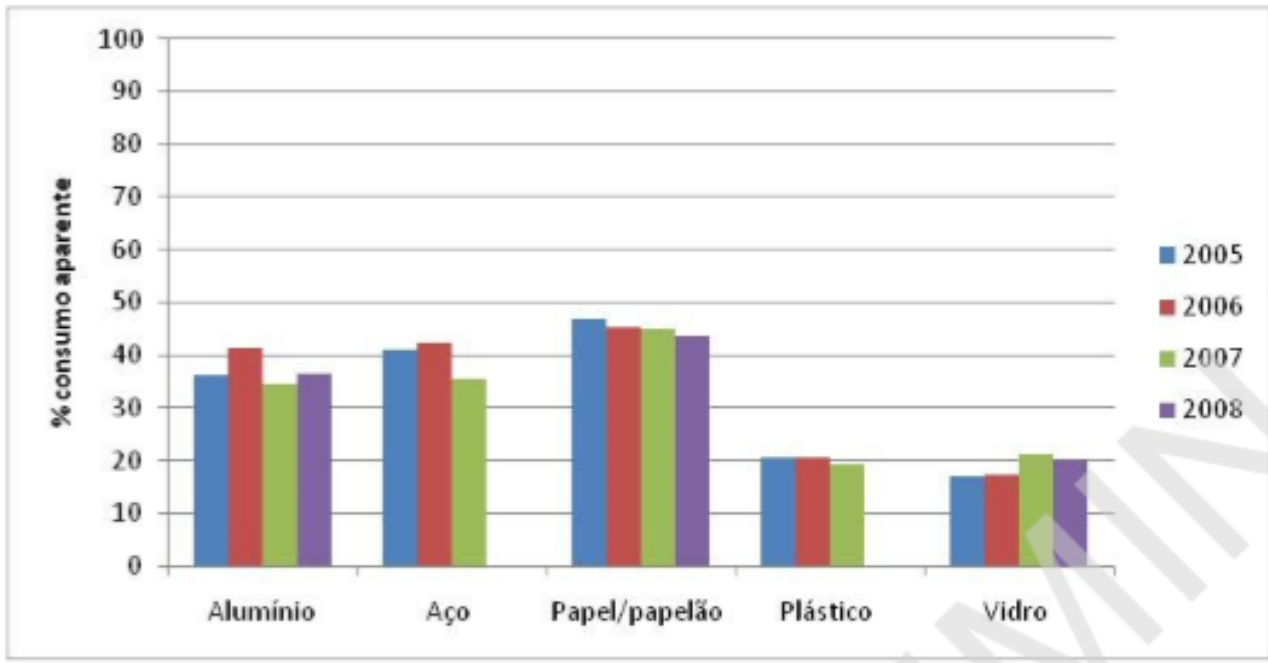

Figura 39 - Taxa de reciclagem por tipo de material.

Fonte: Plano Nacional de Resíduos Sólidos, 2011.

Os dados apresentados foram calculados a partir da reciclagem total dos resíduos (incluindo reciclagem pré-consumo e coleta seletiva informal) em função do consumo aparentes. A análise dessa informação permite a separação dos resíduos em dois grandes grupos, de acordo com o percentual de reciclagem: alumínio, aço e papel/papelão possuem taxas de reciclagem de acima de $35 \%$; por outro lado plástico e vidro alcançam valores próximos a $20 \%$. 
Quatros setores industriais - alumínio, papel, plástico e vidro - possuem considerável participação nas atividades de reciclagem no país, porém nem todos possuem indicadores confiáveis.

A Figura 39 apresenta os índices de reciclagem disponíveis para três desses materiais. Os índices considerados mostram, de maneira geral, uma estabilidade no volume de reciclagem no país. (ABRELPE, 2013).

Tanto os índices do alumínio quanto de aparas de papel e papelão no Brasil são bastante consolidados, seja pela própria indústria, como pela atuação dos catadores de material reciclável. Considerando os setores estudados neste relatório, o segmento de papel e papelão apresenta a taxa de recuperação de resíduos mais elevada, embora isto se deva à natureza dos produtos de papel, que, em sua maioria, têm um ciclo de vida curto.

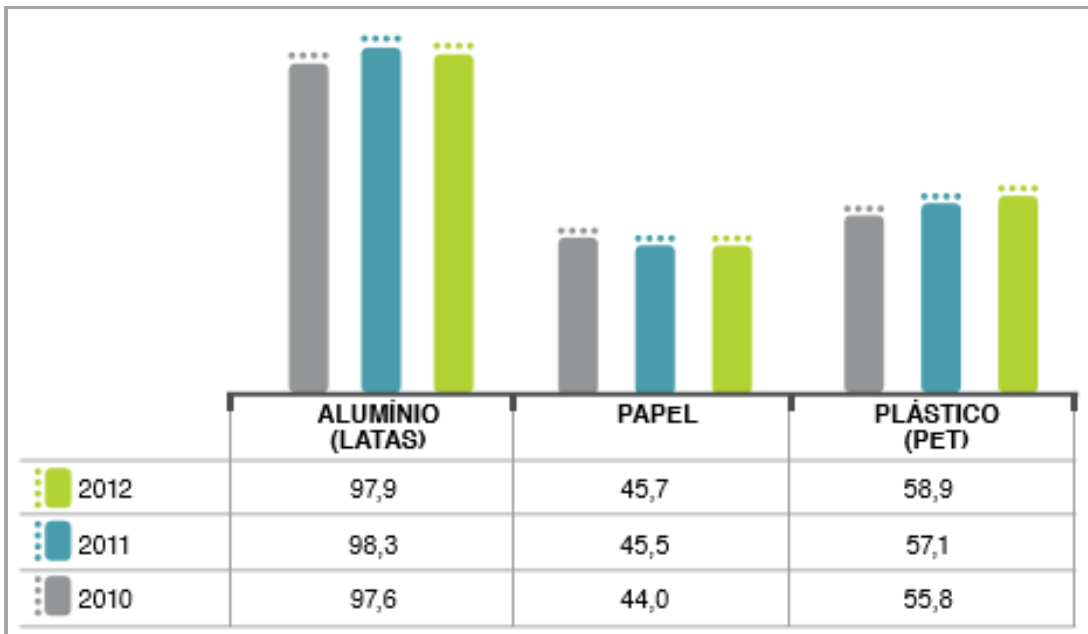

Figura 40 - Índices de reciclagem - alumínio, papel e plástico - 2010 a 2012. Fonte: CEMPRE, 2012.

A avaliação da reciclagem de plásticos requer uma análise mais cuidadosa, devido à diversidade de polímeros envolvidos. Como não há uma única organização por trás da indústria do plástico, o Plano Nacional de Resíduos Sólidos apresenta cenário de reciclagem de plásticos a partir de dados do Ipea conforme demonstra a Tabela 21.

Outra dificuldade na coleta de dados sobre a reciclagem de plástico é a grande quantidade de pequenas empresas envolvidas, o que dificulta pesquisas com todo o universo, sendo os dados elaborados a partir de pesquisas amostrais.

Dos materiais analisados nesta pesquisa, o plástico, como um todo, é aquele com menor taxa de reciclagem. Os vários polímeros, entretanto, têm comportamentos bastante distintos.

O PET talvez seja o segmento que vem obtendo melhor resultado, com taxas de reciclagem pós-consumo da ordem de 60\%. O PEBD (polietileno de baixa densidade) aparece em segundo lugar, com uma reciclagem pós 
consumo de cerca de $20 \%$. Os demais polímeros apresentam taxas inferiores a $10 \%$.

Dessa forma, comparando os diferentes materiais, os plásticos são aqueles que apresentam menor taxa de recuperação, sendo potenciais alvos para políticas específicas de estímulo à reciclagem.

\begin{tabular}{|c|c|c|c|c|}
\hline Reciclagem Plástico & Unidade & 2005 & 2006 & 2007 \\
\hline Resíduo Reciclado & $1 \mathrm{milt}$ & 860,0 & 914,0 & 962,0 \\
\hline Industrial & $1 \mathrm{milt}$ & 335,4 & 402,2 & 375,0 \\
\hline Pos Consumo & $1 \mathrm{milt}$ & 455,1 & 511,8 & 592,0 \\
\hline PEAD & $1 \mathrm{milt}$ & 51,9 & - & 72,0 \\
\hline PEBD & $1 \mathrm{milt}$ & 89,9 & - & 112,0 \\
\hline PET & $1 \mathrm{milt}$ & 244,4 & - & 289,0 \\
\hline $\mathrm{PP}$ & $1 \mathrm{milt}$ & 32,6 & - & 53,0 \\
\hline PS & $1 \mathrm{mil} \mathrm{t}$ & 18,4 & - & 31,0 \\
\hline PVC & $1 \mathrm{mil} \mathrm{t}$ & 9,7 & - & 22,0 \\
\hline Outros & $1 \mathrm{milt}$ & 77,6 & - & 7,8 \\
\hline Taxa de Reciclagem & $\%$ & 20,6 & 20,4 & 19,3 \\
\hline Taxa de Recicl. Ind & $\%$ & 8,0 & 9,0 & 7,5 \\
\hline Taxa de Recicl. Pos C & $\%$ & 12,9 & 11,4 & 11,8 \\
\hline PEAD & $\%$ & 7,5 & - & 10,9 \\
\hline PEBD & $\%$ & 16,5 & - & 19,5 \\
\hline PET & $\%$ & 49,3 & - & 53,1 \\
\hline PP & $\%$ & 3,1 & - & 4,4 \\
\hline PS & $\%$ & 6,4 & - & 8,8 \\
\hline PVC & $\%$ & 1,4 & - & 2,7 \\
\hline
\end{tabular}

Tabela 21 - Reciclagem do plástico - 2005 a 2007.

Fonte: Plano Nacional de Resíduos Sólidos, 2011.

Com relação à reciclagem do vidro, os dados disponíveis também são mais antigos, conforme tabela abaixo. O vidro é caracterizado pela forte possibilidade de reutilização, sendo estimado que cerca de $20 \%$ das embalagens são reutilizadas pela indústria. Além do reuso industrial, estimativas indicam que o reuso caseiro e informal seria responsável por $33 \%$ dos destinos destas embalagens (Abrelpe, 2010).

\begin{tabular}{lcrrrr|}
\hline Reciclagem do Vidro & Unidade & \multicolumn{1}{c}{$\mathbf{2 0 0 5}$} & \multicolumn{1}{c}{$\mathbf{2 0 0 6}$} & \multicolumn{1}{c}{$\mathbf{2 0 0 7}$} & \multicolumn{1}{c}{$\mathbf{2 0 0 8}$} \\
\hline Embalagens Reutilizadas & 1 mil t & 187,8 & 192,1 & 212,5 & 208,1 \\
Resíduo Reciclado (embalagens) & 1 mil t & 422,6 & 441,9 & 499,4 & 489,0 \\
Taxa de Reciclagem (embalagens) & $\%$ & 45 & 46 & 47 & 48 \\
\hline
\end{tabular}

Tabela 22 - Reciclagem do vidro - 2005 a 2008.

Fonte: Plano Nacional de Resíduos Sólidos, 2011.

A reciclagem também tem relação com a logística reversa, conceituada pela PNRS conforme a seguir e definida como um dos instrumentos desta Política, unida à coleta seletiva.

[...] "instrumento de desenvolvimento econômico e social caracterizado por um conjunto de ações, procedimentos e meios destinados a viabilizar a coleta e a restituição dos resíduos sólidos ao setor empresarial, para reaproveitamento, em seu ciclo ou em outros ciclos produtivos ou outra destinação final ambientalmente adequada."

A Política impõe um sistema de logística reversa para 6 tipos de produtos, como também estende tais orientações a embalagens em geral, 
considerando o grau e extensão do impacto à saúde publica e viabilidade econômica do sistema logístico, estas ainda sem obrigação direta regulamentada por instrumentos legais.

Atualmente estão em andamento as discussões sobre a elaboração dos acordos setoriais e posteriormente a determinação da cadeia de logística reversa para vários resíduos, tais como embalagens (em geral), medicamentos e lâmpadas, além dos resíduos objetos obrigatórios determinados pela PNRS, o que potencializa o mercado de reciclagem brasileiro.

\subsubsection{Metas propostas para a GRU no Brasil}

A PNRS (Lei 12.305/2010) e seu decreto no 7.404 definem metas confirme a seguir.

- Eliminação de lixões e aterros controlados até 2014 e Disposição Final Ambientalmente Adequada de Rejeitos;

- Publicação de planos estaduais e municipais em 4 anos, sob pena de redução dos recursos da União destinados aos locais sem divulgação desta política;

- Coleta seletiva como instrumento essencial para atingimento da meta de disposição final ambientalmente correta dos rejeitos;

- O sistema de coleta seletiva será implantado pelo titular do serviço público de limpeza urbana e manejo de resíduos sólidos e deverá estabelecer, no mínimo, a separação de resíduos secos e úmidos e progressivamente estendido para a separação dos resíduos secos em suas parcelas específicas, segundo metas estabelecidas nos respectivos planos.

A PNRS cita o Plano Nacional de Resíduos Sólidos como o principal documento para a regulamentação de metas.

Tal Plano ainda encontra-se em versão preliminar, sob discussão, sem publicação de decreto. Mesmo sem publicação, tais metas definidas no plano serviram como base para os objetivos definidos para estados e municípios.

Desta forma, seguem as diretrizes e objetivos estabelecidos no Plano Nacional de Resíduos Sólidos (2011):

- Eliminação de lixões e aterros controlados até 2014 e Disposição Final Ambientalmente Adequada de Rejeitos, conforme estabelecido na lei 12.305/2010;

- Recuperação de lixões compreendendo as ações de queima pontual de gases, coleta de chorume, drenagem pluvial, compactação da massa e cobertura vegetal; 
- Manter os atuais patamares de geração de resíduos sólidos urbanos, tomando-se por referência o ano de 2008 (equivale a uma taxa média de $1,1 \mathrm{~kg} / \mathrm{habitante} / \mathrm{dia})$ com posterior redução;

- Redução de $70 \%$ dos resíduos recicláveis secos dispostos em aterros sanitários, com base na caracterização nacional em 2012;

- Inclusão e fortalecimento da organização de 600.000 catadores de materiais reutilizáveis e recicláveis;

- Induzir a compostagem da parcela orgânica dos RSU e a geração de energia por meio do aproveitamento dos gases provenientes da biodigestão de composto orgânico e dos gases gerados em aterros sanitários (biogás);

- A elaboração de planos de resíduos sólidos é condição para que os Estados (a partir de 2012), o Distrito Federal e os Municípios (a partir de 2014) tenham acesso a recursos da União ou por ela controlados, bem como para que sejam beneficiados por incentivos ou financiamentos de entidades federais de crédito.

As metas foram definidas considerando 3 cenários: favorável/legal, intermediário e desfavorável, conforme Figura 41 a seguir.

O relatório Lixo Zero, elaborado pelo Instituto Ethos, ONG Planeta Sustentável e ONG Cata Ação (ABRAMOVAY et al, 2013) demonstra os locais que apresentam a gestão regulamentada em lei, conforme Figura 42 , a seguir.

Tal quadro comprova o avanço das Regiões Sul, Sudeste e Centro Oeste na gestão de resíduos sólidos, com $100 \%$ dos estados com política regulamentada, ao contrário das regiões Norte e Nordeste, somente com 5 (cinco) estados regulamentados. 


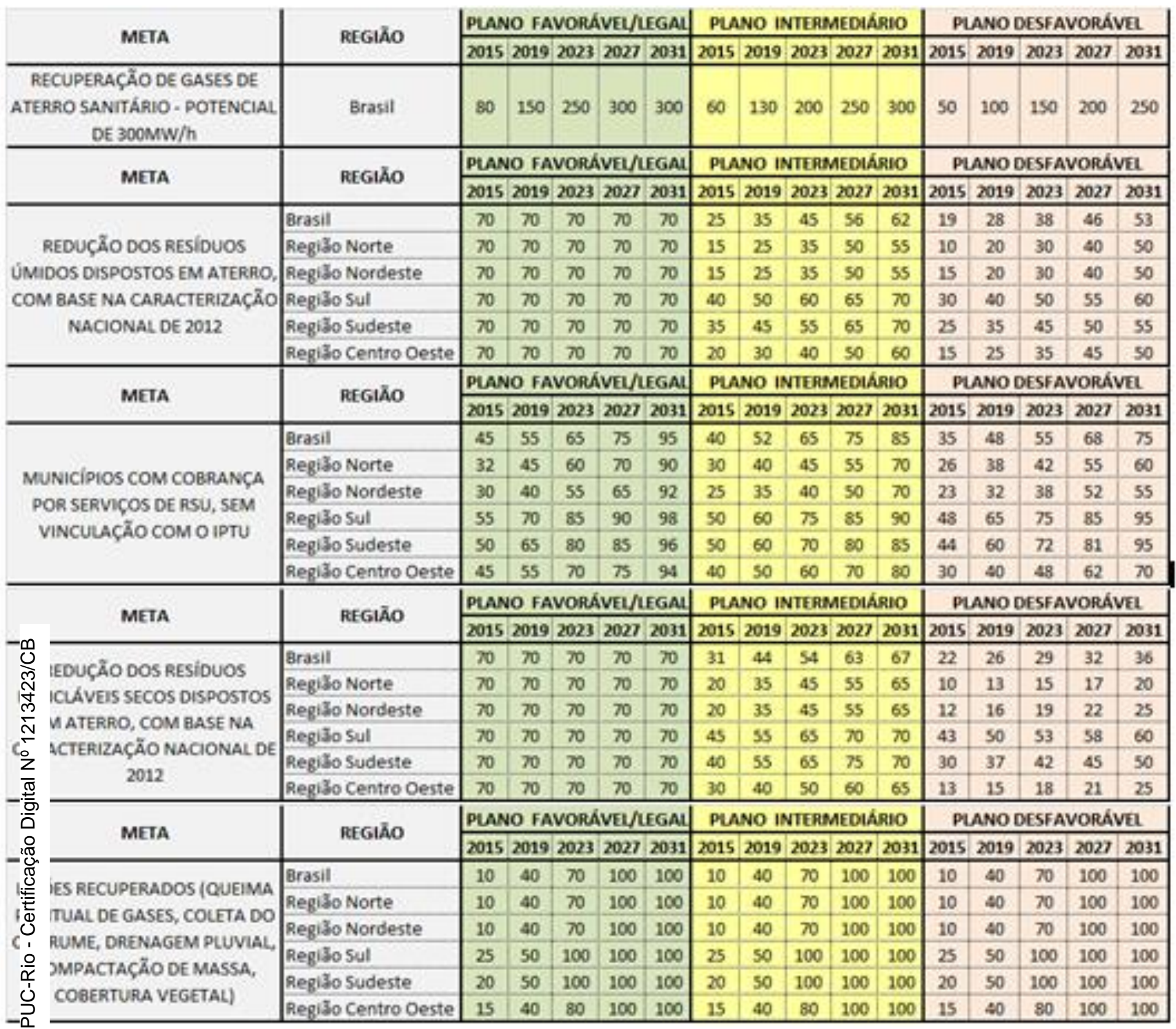

\begin{tabular}{|c|c|c|c|c|c|c|c|c|c|c|c|c|c|c|c|c|}
\hline \multirow{2}{*}{ META } & \multirow{2}{*}{ ricilo } & \multicolumn{5}{|c|}{ PUNO FAVCEAWE/LEGML } & \multicolumn{5}{|c|}{ 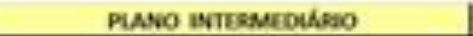 } & \multicolumn{5}{|c|}{ PUNO DESFAVORAVE } \\
\hline & & 2005 & 2010 & 20021 & 20027 & 2011 & 2015 & 2000 & 200 & 20027 & 2013 & 2015 & 2019 & 20023 & $\sin$ & 2011 \\
\hline \multirow{4}{*}{$\begin{array}{c}\text { INCLUSÃOE } \\
\text { FOATALECINENTO } \\
\text { DA CACANIZACZ̄o } \\
\text { DE } 600.000 \\
\text { CATADCRES }\end{array}$} & Regilo Norte & 7.705 & 12.144 & $16 \times 5$ & & & 7.745 & 12. 25 & 13.600 & 26500 & & 2.745 & 10.75t & 12.144 & $11 \pm 00$ & 16300 \\
\hline & egilo Nondeste & 61.360 & 50.204 & 135.36 & & & 63.160 & 87,984 & 212.000 & 135.300 & & 63.160 & 87.384 & 99.264 & 112.800 & 235.360 \\
\hline & hegilo sudeite. & 100564 & 17217 & 244.730 & & & 100.564 & 152.602 & 155.650 & 234700 & & $305 \times 54$ & 152.007 & 172.172 & 155.650 & 234.750 \\
\hline & Resilo centeo Oeste & 30.920 & 48,020 & 66300 & & & 30,929 & 42,095 & 55.250 & 66.300 & & 10.929 & 43.095 & 45.600 & 35.250 & 66.300 \\
\hline
\end{tabular}

Figura 41 - Plano Nacional de Resíduos Solidos - Metas 2015 a 2031.

Fonte: Plano Nacional de Resíduos Sólidos, 2012. 
Estados com política de gestáo dos resíduos sólidos regulamentada por lei

\begin{tabular}{|c|c|c|}
\hline Reglaso & Estado & Instrumento legal \\
\hline \multirow{2}{*}{ Norte } & Rondonila & Le1 $n^{p} 1.145 / 2002$ \\
\hline & Roraima & Let $n^{P} 416 / 2004$ \\
\hline \multirow{3}{*}{ Nordeste } & Ceara & $\begin{array}{l}\text { Lel } n^{2} 13.103 / 2001 \\
\text { Decreto } n^{\circ} 26.604 / 2002\end{array}$ \\
\hline & Pernambuco & $\begin{array}{l}\text { Lel } n^{2} 14.236 / 2010 \\
\text { Decreto } n^{\circ} 23.941 / 2002 \\
\text { Lel } n^{2} 12.0002001 \text { (revogada) }\end{array}$ \\
\hline & Sergipe & Lel $n^{2} 5.857 / 2006$ \\
\hline \multirow{4}{*}{ Sudeste } & Espinto Santo & Let $n^{\circ} 9.264 / 2009$ \\
\hline & Minas Gerals & $\begin{array}{l}\text { Lel } n^{\circ} 18.031 / 2009 \\
\text { Decreto } n^{\circ} 45.181 / 2009\end{array}$ \\
\hline & Rio de Janeiro & $\begin{array}{l}\text { Lel } n^{2} 4.191 / 2003 \\
\text { Decreto } n^{\circ} 41.084 / 2007\end{array}$ \\
\hline & STo Paulo & $\begin{array}{l}\text { Lel } n^{\circ} 12.3002006 \\
\text { Decreto } n^{\circ} 54.645 / 2009 \\
\text { Decreto } n^{\circ} 57.071 / 2011\end{array}$ \\
\hline \multirow{3}{*}{ Sul } & Parana & $\begin{array}{l}\text { Lel } n^{\circ} 12.493 / 1999 \text { (alterada) } \\
\text { Lel } n^{P} 15.862 / 2008 \\
\text { Decreto } n^{\circ} 6.674 / 2002\end{array}$ \\
\hline & Rlo Grande do Sul & $\begin{array}{l}\text { Lel } n^{\circ} 9.921 / 1993 \\
\text { Decreto } n^{\circ} 38.356 / 1998\end{array}$ \\
\hline & Santa Catarina & Let $n^{P} 13.557 / 2005$ \\
\hline \multirow{4}{*}{ Centro-Oeste } & Golats & $\begin{array}{l}\text { Let } n^{2} 17.242 / 2010 \\
\text { Let } n^{P} 16.746 / 2009 \\
\text { Lel } n^{P} 14.892 / 2004 \\
\text { Lel } n^{P} 14.2492002 \text { (alterada) }\end{array}$ \\
\hline & Mato Grosso & $\begin{array}{l}\text { Let } n^{2} 7.862 / 2002 \text { (alterada) } \\
\text { Lel } n^{2} 9.263 / 2009\end{array}$ \\
\hline & Mato Grosso do Sul & Let $n^{p} 2.080 / 2000$ \\
\hline & Distrito Federal & $\begin{array}{l}\text { Lel } n^{2} 3.232 / 2003 \\
\text { Decreto } n^{\circ} 29.399 / 2008\end{array}$ \\
\hline
\end{tabular}

Figura 42 - Estados com Política de Gestão de RSU regulamentada por lei. Fonte: Lixo Zero, 2013.

Muitas cidades e municípios ainda não apresentaram sua Política de Gestão de RSU, bem como não apresentaram medidas para o cumprimento das demais metas da PNRS.

Desta forma, o decreto № 8.211 foi publicado em 21 de Março de 2014, alterando a data limite para 31 de dezembro de 2015 para e existência de um plano de saneamento básico como condição de acesso aos recursos da União.

Além desta medida, a prorrogação da data para o encerramento dos lixões foi requerida pela Confederação Nacional de Municípios, porém foi negada pelo Ministério do Meio Ambiente. 


\subsection{Gestão de Resíduos no Estado do Rio de Janeiro}

O Estado do Rio de Janeiro apresenta uma população de 15.989 .929 habitantes (IBGE, 2010 apud PERS 2013), área de $43.780 .157 \mathrm{~km}^{2}$ e consequente densidade demográfica de 365,23hab/km² (IBGE,2010 apud PERS 2013). Grande parte da população (97\%) localiza-se em áreas urbanas e somente $3 \%$ em áreas rurais.

É composto por 92 municípios e 8 Regiões Administrativas, dentre as quais se insere a região Metropolitana, onde se concentra a maior parte da população ( $74 \%$ da população: 11.835 .708 habitantes). Apresenta um IDH de 0,802 (PNUD/IPEA/FJP, 2000 apud PERS 2013)

De acordo com as estimativas e pesquisas realizadas para a criação do Plano Estadual de Resíduos Sólidos do Estado do Rio de Janeiro (PERS/RJ), esta região gera aproximadamente 17.000/ton de resíduos por dia, com índice médio de geração per capita de $1,10 \mathrm{~kg} / \mathrm{hab} / \mathrm{dia}$. A figura abaixo apresenta este índice detalhado por Região Administrativa.

\begin{tabular}{|c|c|}
\hline \multirow{2}{*}{ Regilo Administrativa } & INDICE DE GERAÇAO PER CAPTTA \\
\hline & $(\mathrm{KG} / \mathrm{HAB} / \mathrm{DIA})$ \\
\hline Regiăo Metropolitana & 1,19 \\
\hline Regiăo Centro Sul Fluminense & 0,73 \\
\hline Regiáo da CostaVerde & 0,81 \\
\hline Regiáo das Baixadas Litorâneas & 0,82 \\
\hline Regiáo do Médio Paraiba & 0,81 \\
\hline Regiáo Noroeste Fluminense & 0,72 \\
\hline Regiáo Norte Fluminense & 0,87 \\
\hline Regiáo Serrana & 0,82 \\
\hline MEDIA ESTADUAL & 1,10 \\
\hline
\end{tabular}

Tabela 23 - Média de índices per capita de RSU nas Regiões do Estado do Rio de Janeiro. Fonte: PERS/RJ, 2013.

Dentro dos municípios, foram verificadas grandes variações nos índices de geração per capita (mínimo de 0,61 kg/hab./dia e máximo de $1,33 \mathrm{~kg} / \mathrm{hab} . / \mathrm{dia}$ ), relacionadas diretamente ao porte populacional do município e à localização geográfica. É importante comentar também que $83 \%$ destes resíduos são gerados pela população da Região Metropolitana.

O Estado possui um Plano Estadual de Resíduos Sólidos do Estado do Rio de Janeiro (PERS/RJ), lançado em 2013, estruturado para um horizonte de 20 anos, com revisão quadrianual prevista. O PERS/RJ faz um diagnóstico dos resíduos sólidos no Estado, analisando a cadeia produtiva da reciclagem, traçando metas. 
De acordo com o Plano, a taxa de cobertura de coleta igual ou superior a $90 \%$, dos quais $5 \mathrm{mil}$ t/dia são considerados resíduos de limpeza urbana $(R L U)$ e $13 \mathrm{mil}$ t/dia de resíduos domiciliares (RDO). A composição gravimétrica dos resíduos coletados apresenta índices acima de 53\% para resíduos orgânicos e acima de $41 \%$ para resíduos recicláveis.

A Tabela 24 demostra a gravimetria por municípios de pequeno, médio e grande porte.

\begin{tabular}{|c|c|c|c|c|c|c|c|c|c|}
\hline \multirow{4}{*}{$\begin{array}{l}\text { Porte dos } \\
\text { Municípios }\end{array}$} & \multirow{4}{*}{$\begin{array}{c}\text { População } \\
\text { Urbana (IBGE } \\
\text { 2010) }\end{array}$} & \multirow{3}{*}{\multicolumn{2}{|c|}{$\begin{array}{l}\text { Quantitativo Estimado de } \\
\text { RSU }\end{array}$}} & \multicolumn{6}{|c|}{ Tipos de Materiais } \\
\hline & & & & Mat Orgânica & Papel & Plástico & Vidro & Metais & Out \\
\hline & & & & $53,28 \%$ & $15,99 \%$ & $19,14 \%$ & $3,28 \%$ & $1,57 \%$ & 6,7 \\
\hline & & Ton/dia & Ton/ano & \multicolumn{6}{|c|}{ Ton/ano } \\
\hline $\begin{array}{l}\text { Peq Porte (até } \\
100.000 \text { hab) }\end{array}$ & 1.800 .494 & $1.330,03$ & $478.810,80$ & $271.581,52$ & $64.800,05$ & $89.202,45$ & $13.550,34$ & $7.565,24$ & 32.5 \\
\hline $\begin{array}{c}\text { Médio Porte (de } \\
100.001 \mathrm{a} \\
1.000 .000 \mathrm{hab})\end{array}$ & 7.343 .299 & $7.234,39$ & $2.604 .380,40$ & $1.381 .102,93$ & $431.545,84$ & $512.802,51$ & $76.829,22$ & $38.805,29$ & 163.2 \\
\hline $\begin{array}{c}\text { Grande Porte } \\
\text { (acima de } \\
1.000 .001 \mathrm{hab} \text { ) }\end{array}$ & 6.320 .446 & $8.406,19$ & $3.026 .228,40$ & $1.612 .374,49$ & $493.893,92$ & $579.220,12$ & $99.260,29$ & $47.511,79$ & 203.9 \\
\hline Total & $15.464 .239,00$ & $16.970,61$ & $6.109 .419,60$ & $3.265 .058,94$ & $990.239,81$ & $1.181 .225,08$ & $189.639,85$ & $93.882,32$ & 399.7 \\
\hline
\end{tabular}

Tabela 24 - Composição gravimétrica do lixo por porte de município do RJ.

Fonte: PERS/RJ, 2013.

Desta forma, pode-se considerar que são descartadas aproximadamente 3,3 milhões de toneladas de matéria orgânica por ano.

Segundo o estudo do PERS/RJ, 35\% dos municípios fluminenses (trinta e dois do total de noventa e dois) apresentam iniciativas referentes à coleta seletiva, gerando um índice de recuperação de 3\% do total da fração seca. Tal indicador soma todos os resíduos recuperados por diversos programas apoiados pelos municípios e não somente os gerados a partir da coleta seletiva.

No que diz respeito aos catadores, o Estado conta com programas específicos para este grupo de profissionais, como o Programa Catadores e Catadoras em Redes Solidárias (www.rj.gov.br) e o Programa Coleta Seletiva Solidária (PCSS - www.coletaseletivasolidaria.com.br).

O Programa Catadores e Catadoras em Redes Solidárias tem como objetivo principal implementar a capacitação de catadores, buscando sua valorização e emancipação e está presente em 41 dos 92 municípios, perfazendo uma abrangência de $45 \%$ destes.

Até outubro de 2012, o programa apresentou: 480 catadores integrados em cooperativas e/ou associações, 21 cooperativas e/ou associações incorporadas aos programas municipais de coleta seletiva solidária, 6 cooperativas e/ou associações criadas a partir da implantação de programas municipais de coleta seletiva solidária. 


\begin{tabular}{|c|c|c|c|c|c|}
\hline \multirow{2}{*}{ Munkipios } & \multirow{2}{*}{ Populacho } & \multicolumn{4}{|c|}{$\begin{array}{l}\text { QuantIDade DE Materal RECUPERAdo } \\
\text { (1000 T/ANo) }\end{array}$} \\
\hline & & Pafels & Puasticos & Metals & Vionos \\
\hline $\begin{array}{c}\text { Pequeno Porte } \\
\text { (populaçao até } \\
100.000 \text { habitantes) }\end{array}$ & 279.026 & 1,34 & 0,81 & 0,42 & 0,25 \\
\hline $\begin{array}{c}\text { Medio Porte } \\
\text { (populaçao de } \\
100.001 \text { a 1.000.000 } \\
\text { habitantes) }\end{array}$ & 3.617 .635 & 19,17 & 10,85 & 4,34 & 2,89 \\
\hline $\begin{array}{l}\text { Grande Porte } \\
\text { (populaçao acima } \\
\text { de 1.000.001 } \\
\text { habitantes) }\end{array}$ & 6.320 .446 & $9 / 48$ & 6,95 & 2,53 & 2,53 \\
\hline \multirow{2}{*}{ TOTAL } & \multirow{2}{*}{ 10.217.107 } & 29,99 & 18,61 & 7,29 & 5,67 \\
\hline & & \multicolumn{4}{|c|}{$61,56 \mathrm{mil} \mathrm{t} / \mathrm{ano}$} \\
\hline
\end{tabular}

Tabela 25 - Quantidade de Resíduos recuperados na coleta seletiva no Estado do RJ. Fonte: PERS/RJ, 2013.

Já o PCSS é executado pelo INEA e tem como principal objetivo a assessoria dos municípios na implantação de Programas Municipais de Coleta Seletiva Solidária, incentivando o desenvolvimento de políticas públicas municipais para o reconhecimento, inclusão, valorização e protagonismo da categoria dos catadores de materiais recicláveis.

Até setembro de 2014, o Programa Coleta Seletiva Solidária despertou o interesse de 78 municípios, orientados para próximos passos da iniciativa, alcançando a marca de 26 municípios com programas municipais de coleta seletiva solidária implantados.

$\mathrm{Na}$ destinação de resíduos, o Estado avançou em medidas ambientalmente corretas. Grande parte dos resíduos sólidos gerados no Estado tem recebido destinação final ambientalmente adequada, incentivada pelo Programa LIXÃO ZERO, em atendimento ao Pacto pelo Saneamento (Decreto Estadual 42.930/2011). Atualmente, aproximadamente $96 \%$ dos resíduos sólidos gerados são encaminhados aos aterros sanitários, implantados no Estado, desde o final de 2013.

Seguindo a determinação da PNRS (2010), o Estado avança no encerramento dos mais de 40 lixões que estavam em operação em 2010, restando menos de 20 a encerrar, quando da publicação da PERS, em 2013. 


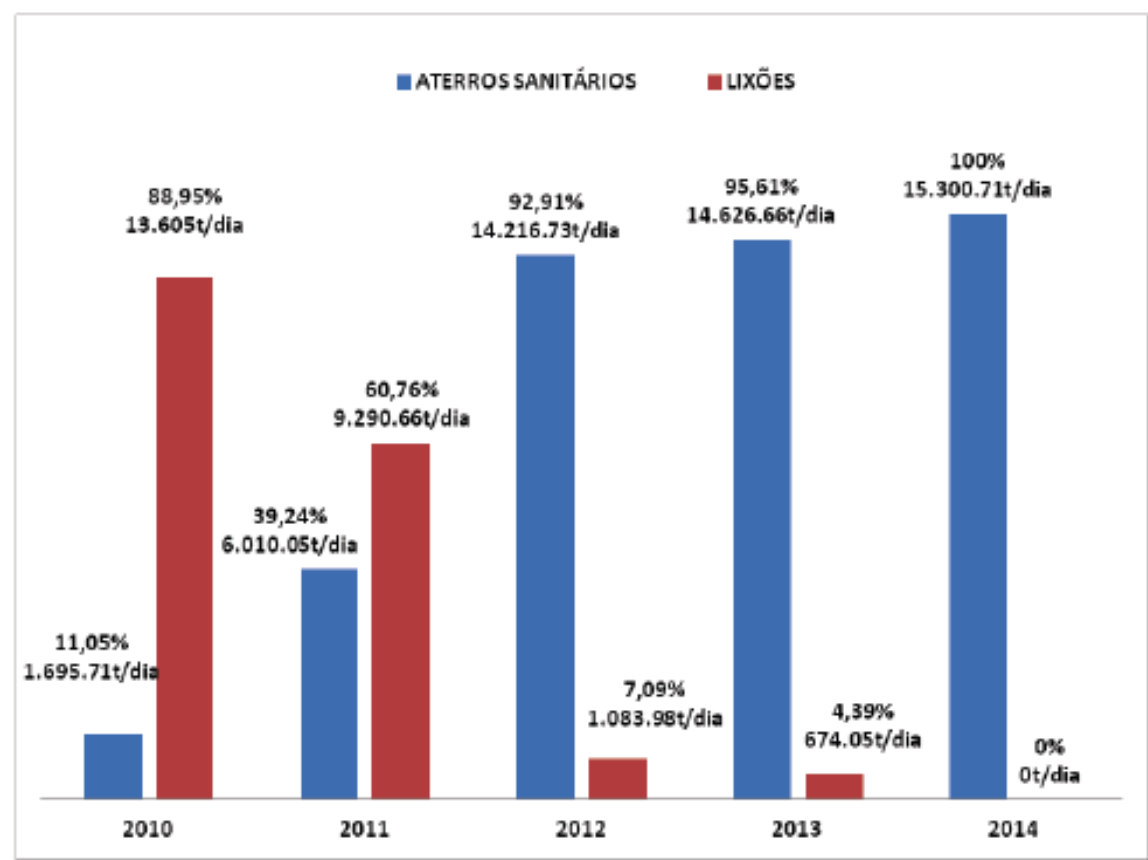

Figura 43 - Evolução do Programa Lixão Zero.

Fonte: PERS/RJ, 2013.

Extrai-se ainda do PERS/ RJ um mercado potencial para a reciclagem, compostagem e/ou digestão anaeróbica a partir da granulometria do RSU do Estado do Rio de Janeiro. O lixo orgânico representa $53 \%$ do total de RSU, o plástico e o papel $42 \%$ e $34 \%$ do lixo seco, respectivamente.

De acordo com a Figura 44, comparando-se os materiais recicláveis consumidos pelo parque reciclador com a composição dos gerados no Estado, é possível perceber o déficit de indústrias voltadas à reciclagem de papéis.

Entretanto, o número de indústrias recicladoras de metais não ferrosos é superior à geração desses materiais no Estado, o que pode indicar que estes estão sendo importados de outros estados para atender à demanda do mercado.

Para a execução do Plano, estudos foram realizados, apontando a importância da formação de consórcios entre municípios, visando a viabilidade técnica para a disposição de RSU, respeitando a escala de sustentabilidade.

Desta forma, foram criados 17 consórcios/arranjos regionais e mantidas algumas soluções individuais, visualizadas conforme a Figura 45 a seguir.

Conforme pode-se visualizar no mapa da Figura 45, o Estado conta com 19 (dezenove) aterros sanitários em operação, 6 (seis) em processo de inauguração e 5 (cinco) em desativação. O mapa não demonstra demais formas de destinação, como a compostagem. 


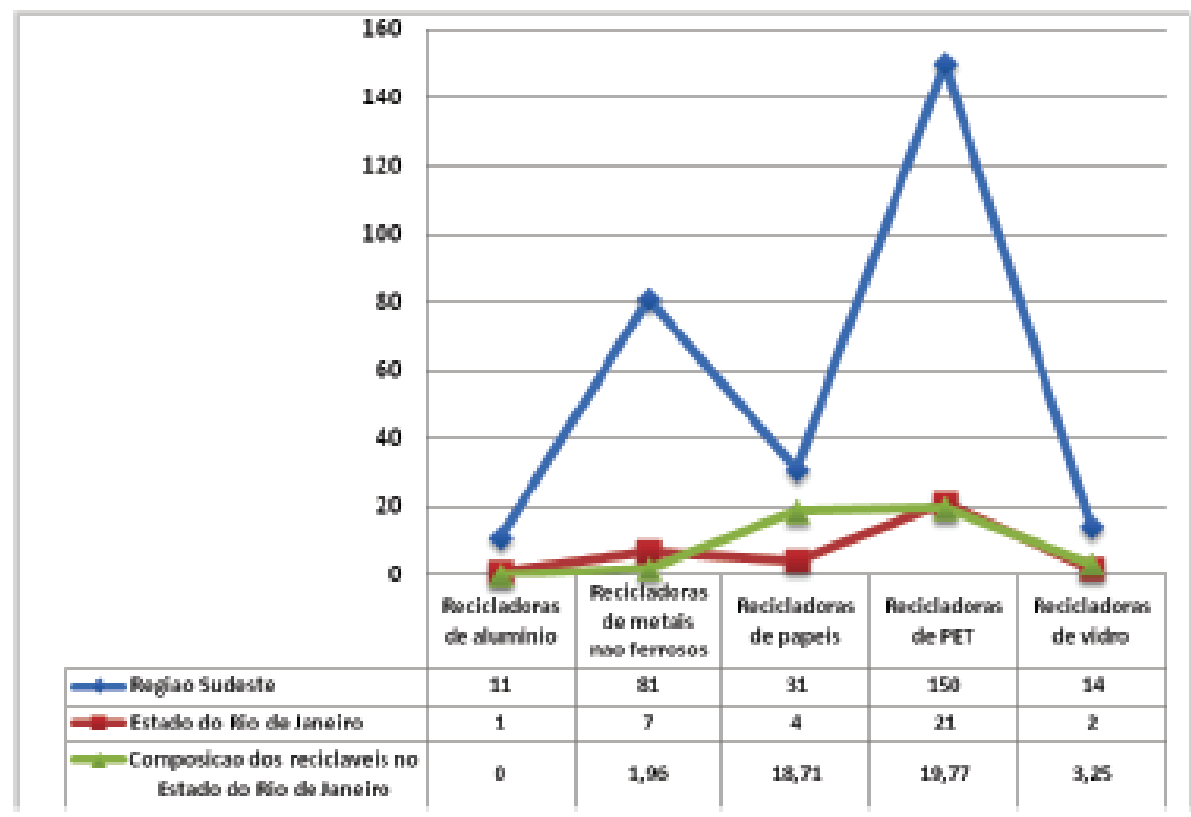

Figura 44 - Relação entre indústrias de reciclagem no Estado e Região Sudeste por tipo de produto. Fonte: PERS/RJ, 2013.

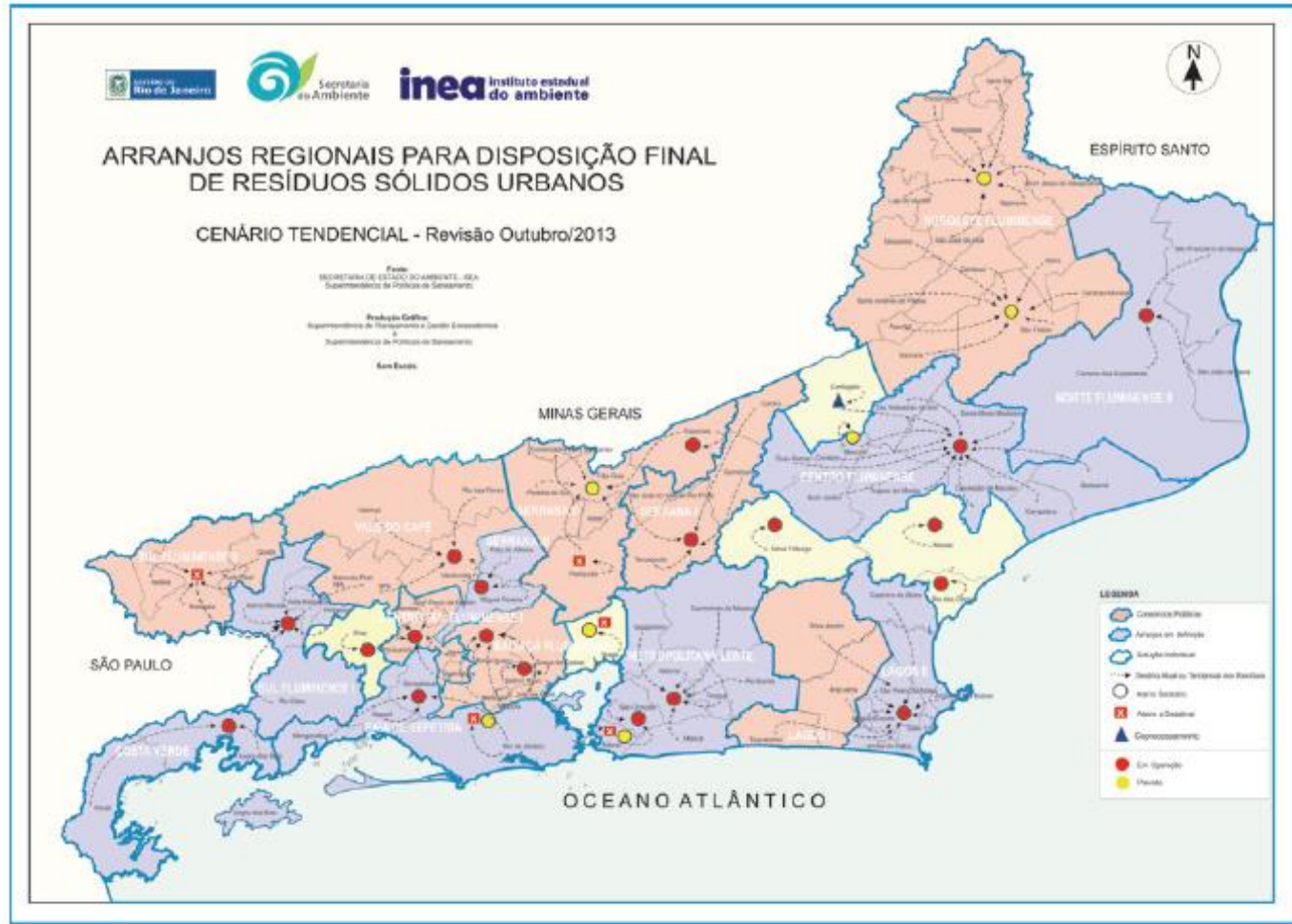

Figura 45 - Cenário proposto para arranjos regionais do Estado do RJ. Fonte: PERS/RJ, 2013.

Alguns consórcios, além dos aterros sanitários, apresentam outras operações em seus centros de tratamento de resíduos: 3 (três) prevêem galpões de triagem (Consócio Serrana I, Consórcio Baixada Fluminense, Consórcio Centro Sul Fluminense I), 2 (dois) consórcios com aproveitamento de biogás (Arranjo Sul Fluminense I, Consórcio Baixada Fluminense), 1 (um) com ecopontos (Consórcio Baixada Fluminense) e 1(um) com compostagem (Consórcio Centro Sul Fluminense I). 
Além dos consórcios, existe uma iniciativa, caracterizada como Solução Individual pelo PERS/RJ, em funcionamento antes da publicação da PNRS (2010). O município de Cantagalo conta com unidades de coprocessamento, triagem e compostagem de RSU.

O cumprimento das diretrizes e objetivos estabelecidos no PERS/RJ é direcionado por metas definidas gradativamente, até 2033, data de validade do Plano. As tabelas abaixo apresentam as metas diretamente relacionadas ao objeto deste estudo.

O estado prevê o aproveitamento energético de gases gerados em aterros sanitários, a organização de catadores, a coleta seletiva e sua abrangência, o beneficiamento de materiais recicláveis, bem como o aproveitamento energético dos rejeitos.

\begin{tabular}{|c|c|c|c|c|c|}
\hline \multirow{2}{*}{\multicolumn{2}{|c|}{ METAS }} & Imediato & Curto prazo & $\begin{array}{l}\text { Médio } \\
\text { prazo }\end{array}$ & $\begin{array}{l}\text { Longo } \\
\text { prazo }\end{array}$ \\
\hline & & 2013-2014 & 2015-2018 & 2019 - & $2025-2033$ \\
\hline MG 1 & $\begin{array}{l}\text { Erradicaçāo dos lixxōes e disposiçăo final dos re- } \\
\text { síduos em Aterros Sanitários }\end{array}$ & $100 \%$ & - & - & - \\
\hline MG 2 & $\begin{array}{l}\text { Recuperação de áreas degradadas por residuos } \\
\text { sólidos }\end{array}$ & $40 \%$ & $100 \%$ & - & - \\
\hline MG 3 & Elaboraçāo e revisāo dos PMGIRS & $100 \%$ & - & - & - \\
\hline MG 4 & $\begin{array}{l}\text { Cobrança de taxa de resíduos domiciliares } \\
\text { Cobrança de tarifa de preço público de G.G. } \\
\text { (usuários dos serviços) }\end{array}$ & $5 \%$ & $100 \%$ & - & - \\
\hline MG 5 & $\begin{array}{l}\text { Aproveitamento energético dos gases gerados } \\
\text { em aterros sanitários e lixōes em recuperaçăo } \\
\text { (com potencial energético a partir de } 660 \mathrm{kWe} \text { ), } \\
\text { sempre que viável técnica e economicamente }\end{array}$ & $10 \%$ & $30 \%$ & $70 \%$ & $100 \%$ \\
\hline MG 6 & Municípios participantes de consórcios & $50 \%$ & $70 \%$ & $80 \%$ & $100 \%$ \\
\hline MG 7 & $\begin{array}{l}\text { Catadores organizados em cooperativas e in- } \\
\text { corporados aos sistemas municipais de coleta } \\
\text { seletiva }\end{array}$ & $50 \%$ & $80 \%$ & - & - \\
\hline
\end{tabular}

Tabela 26 - Metas do Estado do RJ para a Gestão de RSU- Grupo 1. Fonte: PERS/RJ, 2013.

\begin{tabular}{|c|c|c|c|c|c|}
\hline \multirow{2}{*}{\multicolumn{2}{|c|}{ METAS }} & Imediato & Curto prazo & $\begin{array}{l}\text { Medio } \\
\text { prano } \\
\end{array}$ & Longo prazo \\
\hline & & 2013-2014 & $2015-2018$ & $2019-2024$ & $2025-2033$ \\
\hline MRSU 1 & Coleta seletiva implantada nos municípios & $100 \%$ & - & - & - \\
\hline MRSU 2 & Abrangência da coleta seletiva nos municipios & $10 \%$ & $20 \%$ & $50 \%$ & $100 \%$ \\
\hline MRSU 3 & $\begin{array}{l}\text { Municipios com tratamento da fraçāo orgánica dos } \\
\text { RSU (municipal ou consorciada) implantados e em } \\
\text { funcionamento }\end{array}$ & $10 \%$ & $20 \%$ & $50 \%$ & $100 \%$ \\
\hline MRSU 4 & $\begin{array}{l}\text { Triagem e beneficiamento dos materiais recicláveis } \\
\text { oriundos da fraçào seca da coleta seletiva }\end{array}$ & $10 \%$ & $40 \%$ & $50 \%$ & $60 \%$ \\
\hline MRSU 5 & Aproveitamento energético de rejeitos & & & $25 \%$ & $50 \%$ \\
\hline
\end{tabular}

Tabela 27 - Metas do Estado do RJ para Gestão de RSU - Grupo 2.

Fonte: PERS/RJ, 2013. 
O PERS não estabelece metas diretas para a instalação de unidades de compostagem, ponto relevante para atendimento da PNRS, porém exige o tratamento da fração orgânica, que deverá atingir $100 \%$ dos municípios a partir de 2025.

A compostagem é colocada como atribuição dos municípios, conforme a Figura 46 a seguir.

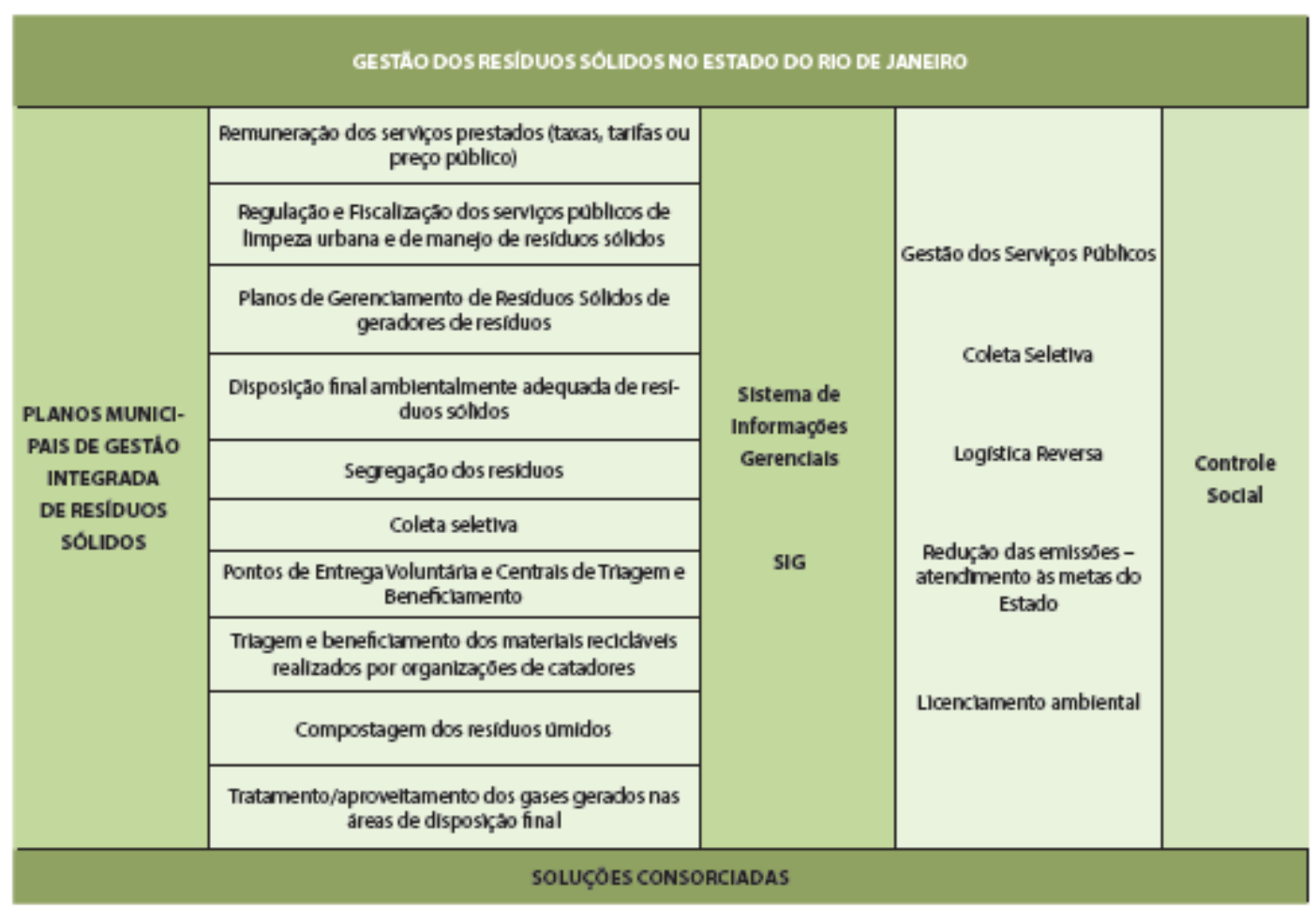

Figura 46 - Principais responsabilidades dos municípios no PERS/RJ.

Fonte: PERS/RJ, 2013.

Em relação ao sucesso da triagem e recuperação de materiais recicláveis, pode-se afirmar que está pautado diretamente na coleta seletiva, processo que também deverá ser controlado através de metas definidas nos planos municipais.

Conforme abordado anteriormente, a coleta seletiva apresenta fraquezas representativas, necessitando de investimento contínuo em programas de conscientização, investimento logístico, bem como demais melhorias no processo para apresentar resultados consideráveis.

Na divulgação do PERS/RJ (2013), o índice de recuperação de recicláveis era de $3 \%$ para 0 Estado. O cenário, também demonstrado pelo PERS/RJ, demonstra a implantação de somente 3 unidades de triagem, número insuficiente para gerar o aumento previsto na meta de mais de 100\% em 3 anos (meta de 3\% em 2012 para 10\% em 2014).

Este ponto também é colocado com atribuição dos municípios, conforme tabela acima. 
No que diz respeito ao TMB, tecnologia foco deste estudo, o PERS/RJ cita a possibilidade de utilização de tecnologias diversas para 0 tratamento dos resíduos secos e úmidos, porém de forma sugestiva e para longo prazo. Cita também oportunidades de geração de energia, como a digestão anaeróbia, o combustível derivado de resíduos e a incineração.

\subsection{Gestão de Resíduos no Município do Rio de Janeiro}

O município do Rio de Janeiro possui uma população de aproximadamente 6,3 milhões de habitantes, área de $1.255 \mathrm{~km}^{2} \mathrm{e}$ consequente densidade demográfica de 5.265,81 hab/km² (IBGE,2010 apud PMGIRS, 2013).

Apresenta um PIB per capita de R\$28.405,95 (IBGE,2009, apud PMGIRS, 2013), IDH de 0.84 (PNUD/IPEA/FJP, 2000) e divide-se em 5 áreas de planejamento, conforme figura abaixo.

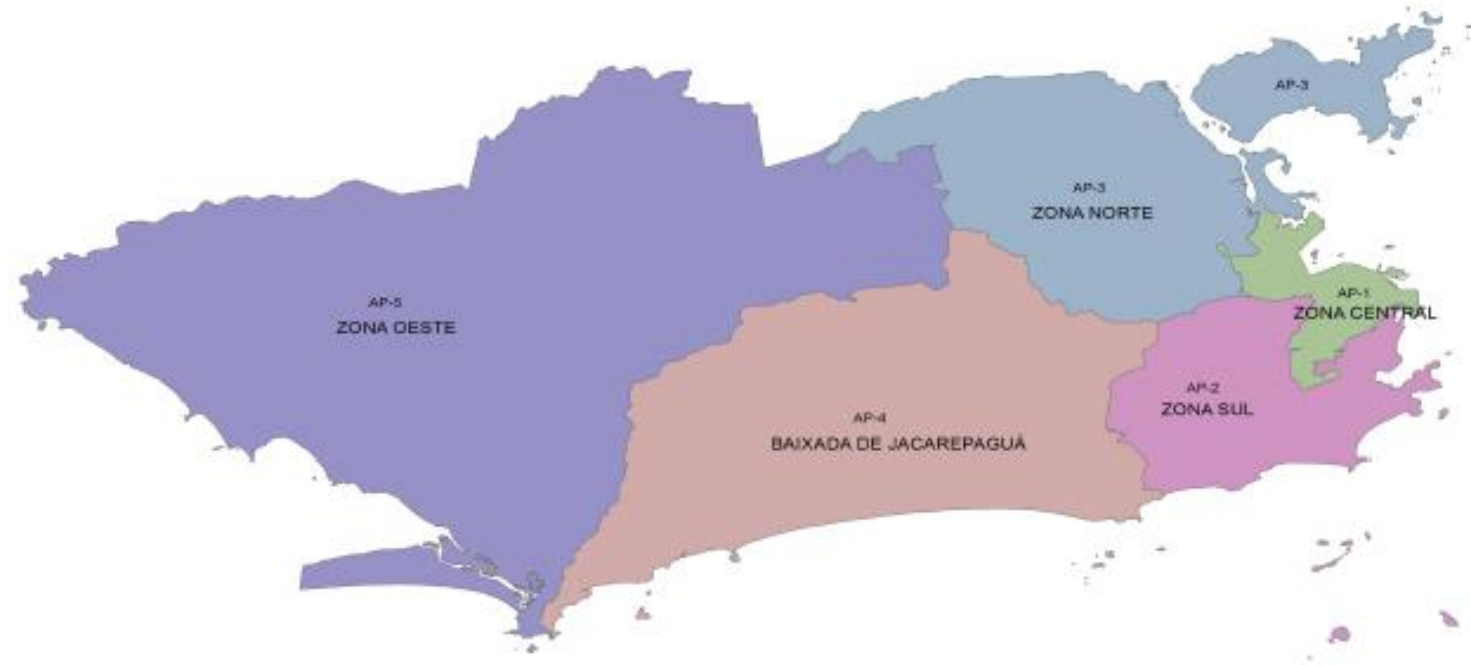

\section{Oceano Atlântico}

Figura 47 - Divisão de regiões no município do Rio de Janeiro.

Fonte: PMGIRS/RJ, 2013.

O município possui seu Plano Municipal de Gestão Integrada de Resíduos Sólidos, regulamentado pelo Decreto 37.337 de 10 de outubro de 2013, desenvolvido SMAC, SECONSERVA e COMLURB.

Esta dissertação utiliza o perfil do município na gestão de resíduos traçado no PMGIRS (2013), complementando o cenário com informações obtidas através de entrevistas e pesquisas de campo.

De acordo com o PMGIRS (2013), os resíduos encaminhados à Comlurb (dezembro, 2011) são da ordem de 10.815 ton/dia, sendo $49,4 \%$ de lixo domiciliar e $32,5 \%$ de lixo público. O restante é compreendido pelas parcelas de resíduos da construção civil, de 
grandes geradores, resíduos hospitalares e remoção gratuita, conforme quadro abaixo.

\begin{tabular}{lrc|} 
& t/dia & $\%$ \\
\hline LIXO DOMICILIAR & 4.777 & 49,42 \\
\hline LIXO PÚBLICO & 3.139 & 32.47 \\
\hline REMOÇÃO GRATUITA & 281 & \\
EMERGÉNCIA & 117 & 6.16 \\
RESÍDUOS DE SERVIÇOS DE SAÚDE & 1 & \\
OUTROS & 196 & 88,05 \\
$\quad$ TOTAL DE COMPETÉNCIA MUNICIPAL & 8.511 & 11,95 \\
\hline GRANDE GERADORES, INCLUINDO DE RCC & 1.155 & 100,00 \\
\hline \multicolumn{1}{l}{ TOTAL GERADO NO MUNICIPIO INCLUINDO GG } & 9.686 &
\end{tabular}

Tabela 28 - Origem dos resíduos do município encaminhados à Comlurb.

Fonte: PMGIRS/RJ, 2013.

Desta forma, considera-se a geração de $1,62 \mathrm{~kg} / \mathrm{hab} /$ dia de resíduos totais da cidade, sendo $0,79 \mathrm{~kg} / \mathrm{hab} / \mathrm{dia}$ de lixo domiciliar e $0,52 \mathrm{~kg} / \mathrm{hab} / \mathrm{dia}$ de lixo público (O PMGIRS considera a população estimada em 2011 pelo Instituto Pereira Passos para tal cálculo - 5.993.557 habitantes).

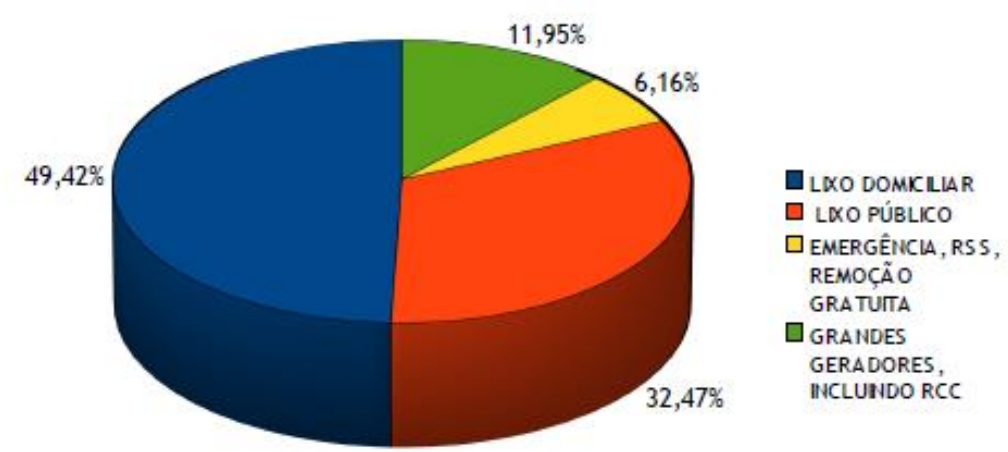

Figura 48 - Participação do RSU no município do Rio de Janeiro.

Fonte: PMGIRS/RJ, 2013.

Detalhando-se por área de planejamento (AP), tem-se os resultados abaixo, conforme a Tabela 29.

A AP.1 (Zona Central) apresenta valor atípico para a geração per capita de resíduo devido à baixa população residente, alta população flutuante (oriunda de outras áreas da Cidade e de outros Municípios) e seu perfil econômico, sendo de negócios e serviços, com elevada geração de resíduos de escritório, resultante da atividade econômica desta área (PMGIRS/RJ, 2013).

Ressalta-se neste Plano a contribuição do setor de Resíduos Sólidos para a emissão de gás metano $(\mathrm{CH} 4)$, apresentando potencial de aquecimento global 21 vezes maior que o gás dióxido de carbono (CO2), conforme Figura 49. 


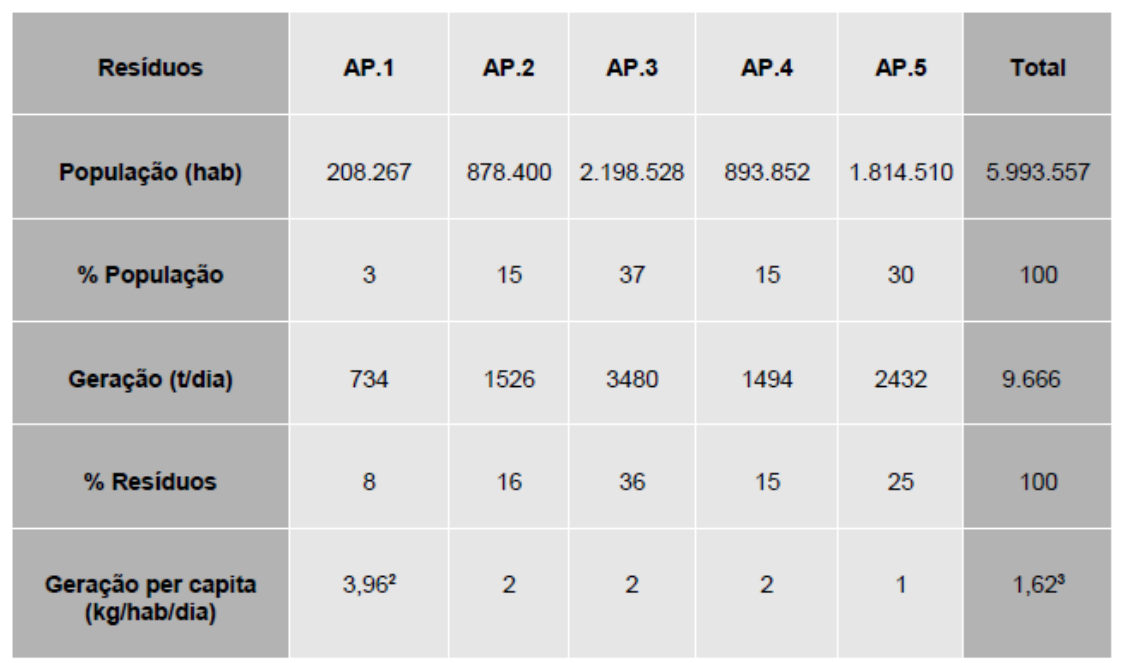

Tabela 29 - Geração de resíduos por área de planejamento do município. Fonte: PMGIRS/RJ, 2013.

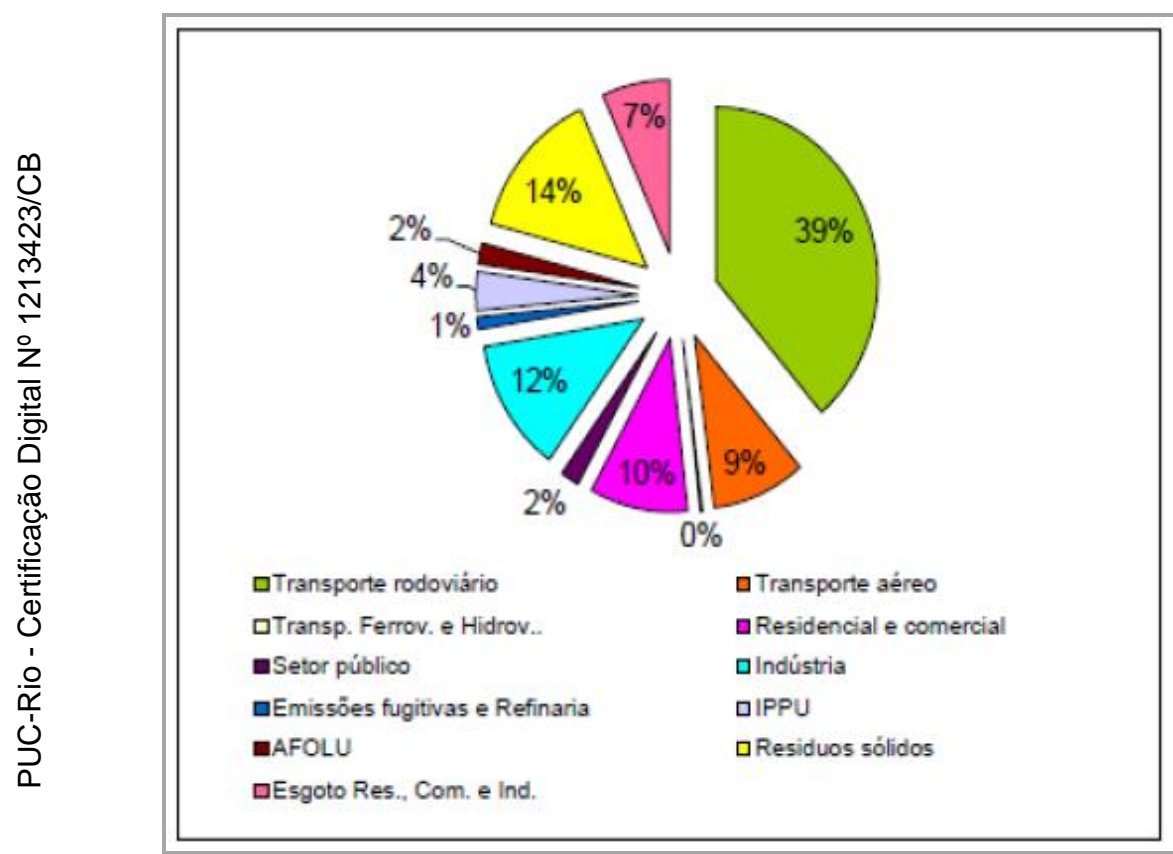

Figura 49 - Participação do RSU nas emissões de GEE da Cidade do Rio de Janeiro. Fonte: PMGIRS/RJ, 2013, apud COPPE/PCRJ/SMAC, 2011.

A composição gravimétrica dos resíduos do município apresenta $41 \%$ de materiais recicláveis e $52,68 \%$ de orgânicos. Dentro do grupo de recicláveis, o plástico e papelão representam quase $90 \%$ do total.

Em 2011, as unidades de destinação final de resíduos sólidos receberam, em media 9.666 toneladas de lixo por dia do município do Rio de Janeiro, discriminadas na Figura 51 a seguir.

As informações desta já encontram-se alteradas, tanto pela desativação do aterro de Gramacho, quanto pela inclusão de novas unidades no que diz respeito ao tratamento de RSU e resíduos originados da coleta seletiva. 


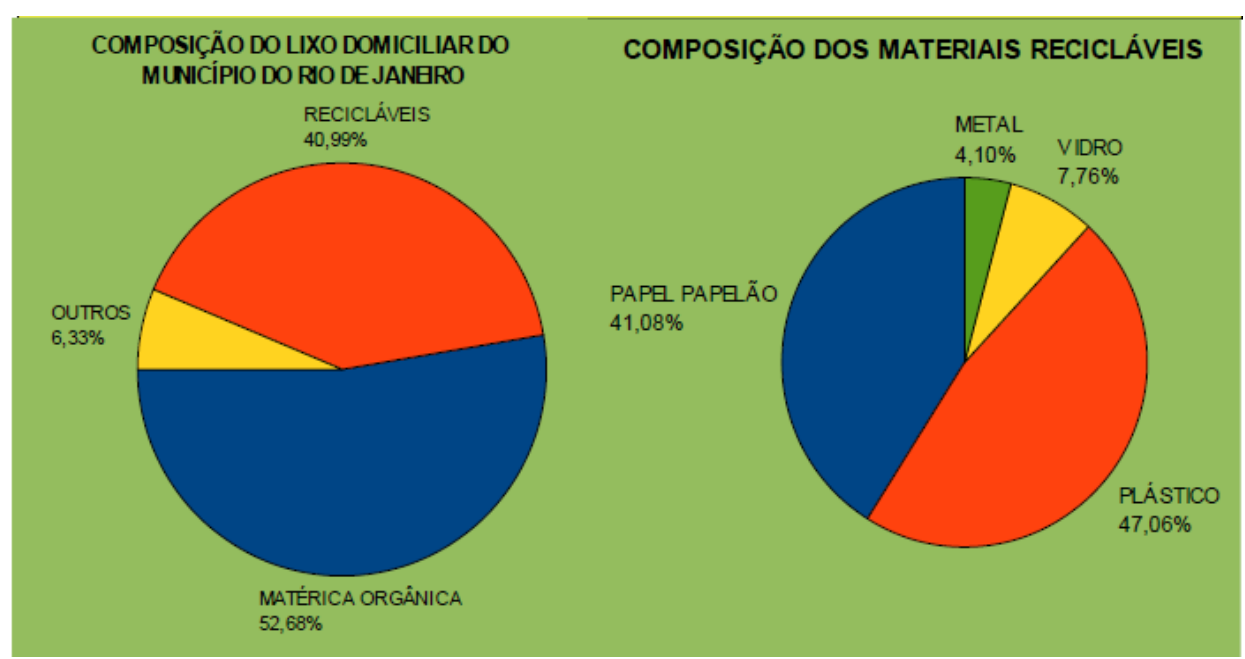

Figura 50 - Composição do lixo domiciliar e de sua fração reciclável.

Fonte: PMGIRS/RJ, 2013.

A Tabela 30 informa as unidades em operação e previstas, bem como o volume médio operado, construídas a partir de informações obtidas a partir de pesquisas de campo, detalhadas nos Apêndices 6.1, 6.2 e 6.4.

Para os resíduos sólidos urbanos, o município conta hoje com 5 unidades de triagem, das 7 previstas. Todas as centrais enviam os resíduos para destinação final ao Aterro de Seropédica - CTR Rio.

A Usina do Caju apresenta-se com uma unidade diferenciada, pois além da triagem, também possui unidades para separação do lixo reciclável e geração de CDR (combustível derivado de resíduo), bem como uma unidade de compostagem, que será detalhada posteriormente no Estudo de Caso.

De acordo com o PMGIRS/RJ (2013), a CTR-Rio, em Seropédica, inaugurada em abril de 2011, passou a receber gradativamente os resíduos gerados na cidade do Rio de Janeiro, viabilizando o processo de desativação do Aterro Metropolitano de Jardim Gramacho-AMJG, em Duque de Caxias, em 2012. A Unidade de Seropédica tem vida útil prevista para 17 anos.

O processo de fechamento do AMJG foi adiantado, resultado de compromissos políticos e ambientais assumidos para a preparação da Conferência das Nações Unidas (Rio+20), mesmo antes de definir ações para compensar o lixo reciclável anteriormente coletado pelos catadores e atualmente enviado para o CTR Seropédica (Nascimento, 2012).

Houve um processo de adaptação para os 1.500 catadores de materiais recicláveis que até então obtinham seu sustento através da catação no Aterro de Gramacho. Estas pessoas receberam indenização e orientação para dar continuidade à sua vida de outras formas (Bastos, 2012). 


\begin{tabular}{|c|c|c|c|c|c|c|c|c|c|}
\hline Urictedes de Recabimentw & otode. (t/dia) & Dorriciliar & Públia & GG & GGRCC & $\begin{array}{l}\text { Perroçăo } \\
\text { Grativita } \\
\text { corrilurb }\end{array}$ & Energencia & autos & Hecpitalar \\
\hline EIRCaju & 3098 & 1.742 & 1.180 & & & 20 & 82 & 74 & \\
\hline ETR Rarepaguá & 967 & 599 & 297 & & & 54 & 7 & 11 & \\
\hline EIR Irajá & 401 & 401 & & & & & & & \\
\hline ATTMissōes & 281 & & 10 & & 192 & 79 & & 0 & \\
\hline Direto Aterno Gramacho & 1.325 & 663 & 478 & & & 102 & 20 & 61 & 1 \\
\hline Direto CIR Seropédica & 106 & 72 & 10 & & & & & 25 & \\
\hline Direto CIR Gericinó & 2525 & 1.300 & 1.165 & & & 26 & 8 & 26 & \\
\hline \multicolumn{10}{|l|}{ subtutal de Residuos por Destino } \\
\hline Destino 1 - Gramacho & 463 & 2.543 & 1.461 & & 192 & 211 & 84 & 143 & 1 \\
\hline Destino 2 - Gericinó & 2525 & 1.300 & 1.165 & & & 26 & 8 & 26 & \\
\hline Destino 3 -Seropédica & 1.543 & 934 & 513 & & & 44 & 25 & 27 & \\
\hline subtutel de resid wo sem $G G$ & $8 \pi 03$ & 4777 & 3.139 & & 192 & $2 \mathrm{B1}$ & 117 & 196 & 1 \\
\hline
\end{tabular}

\begin{tabular}{|c|c|c|}
\hline $\begin{array}{l}\text { Residuos de Grandes Geradores por Destino } \\
\text { Go ETR Caju - Seropédica }\end{array}$ & 267 & 267 \\
\hline GoETR Ecarepeguá - Seropédica & $\pi$ & $\pi$ \\
\hline Qutros atenvos (estimado) & 600 & 620 \\
\hline Zona Qeste - Direto CTR Seropédica & 7 & 7 \\
\hline Subtotal de resid os amGG & 964 & 964 \\
\hline
\end{tabular}

\begin{tabular}{|l|l|llllllll}
\hline Total de Refiduoc D RUComGG & 9.666 & 4.777 & 3.139 & 964 & 192 & 281 & 117 & $1 \%$ & 1
\end{tabular}

Recebimento de RCC nec Uridades de Destino

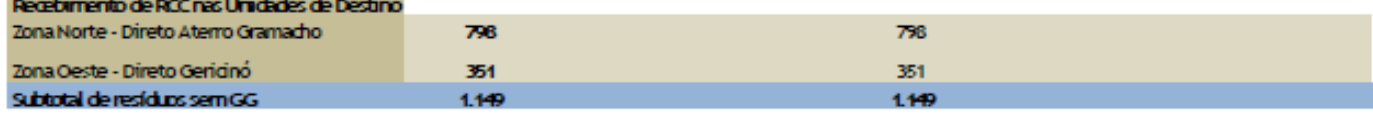

subtotal deresid os sem $G$ G

ETR - Estaçâ de Transfertencia

ATT-Área de Transbordo e Triagem

Energência - Remoç̃es Emergenciais (demoliç̃es, grandes remog̣̃es etc)

GO-Grande Geradore de residuos assemelhados ao lixo donicliar

GG RCC - Grande de residuos da constucẫo aivil

Qutros - Particulares e órgãos públicos

RCC- Residuos da construção ávil

Figura 51 - Geração de resíduos e destinação no município em 2011.

Fonte: PMGIRS/RJ, 2013.

\begin{tabular}{|c|c|c|c|}
\hline UNIDADE & $\begin{array}{l}\text { Operação } \\
\text { (ton/dia) }\end{array}$ & $\begin{array}{c}\text { Representa } \\
\text { tividade }\end{array}$ & Situação \\
\hline ETR Caju & 3.500 & $40,2 \%$ & Em operação \\
\hline ETR Jacarepaguá & 1.200 & $13,8 \%$ & Em operação \\
\hline ETR Marechal Hermes & 1.600 & $18,4 \%$ & Em operação \\
\hline ETR Santa Cruz & 900 & $10,3 \%$ & Em operação \\
\hline ETR Bangu & 1.500 & $17,2 \%$ & Em operação \\
\hline ETR Taquara & & & Prevista para 2015 \\
\hline ETR Penha & & & Prevista para 2015 \\
\hline Total RSU & 8.700 & $100,0 \%$ & \\
\hline
\end{tabular}

Tabela 30 - Unidades de Triagem de RSU no município.

Fonte: Adaptado de entrevistas realizadas na Comlurb e visitas técnicas (2014).

No decorrer de 2011, a quantidade de resíduos inicialmente vazada, da ordem de $1.000 \mathrm{t} / \mathrm{dia}$, passou a 5.500 toneladas diárias em 2011, processando em 2014 as 9.000 toneladas diárias, estas encaminhadas a partir das unidades de triagem, bem como originadas de grandes geradores (PMGIRS, 2013). 


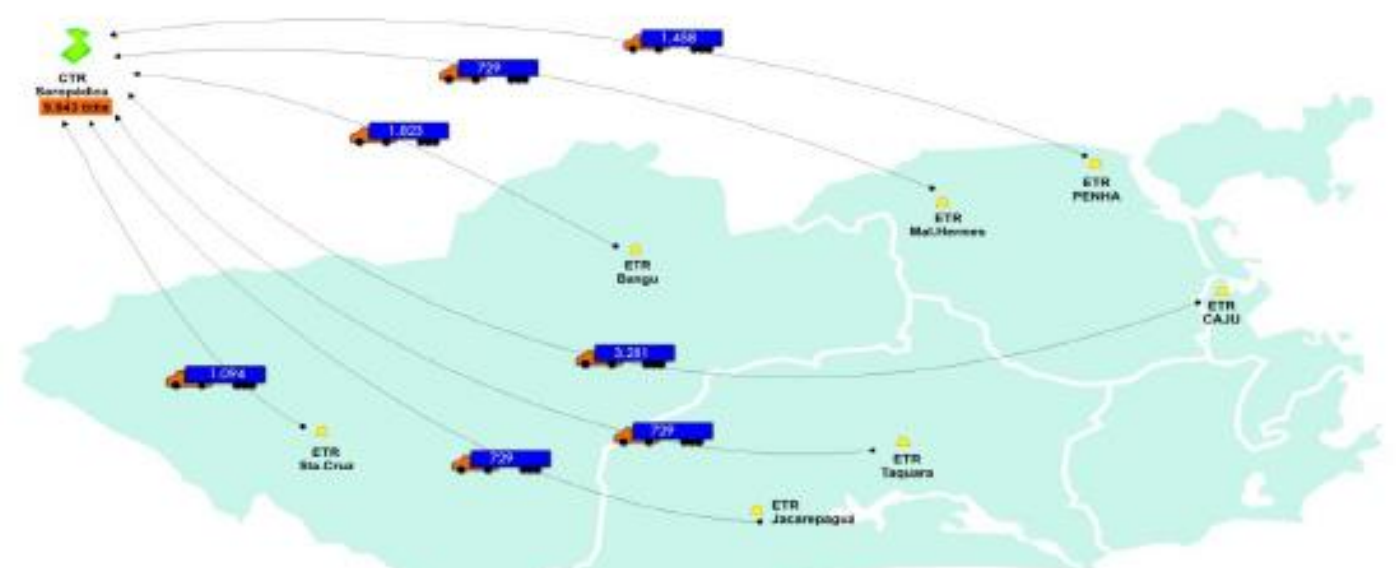

Figura 52 - Fluxo logístico proposto para Transferência de resíduos com o CTR-Rio. Fonte: PMGIRS/RJ, 2013.

Entre as principais tecnologias empregadas pela CTR Rio estão a tripla camada de impermeabilização do solo feita com mantas reforçadas de polietileno de alta densidade (PEAD) e sensores ligados a um software que indica qualquer anormalidade no solo.

Além disso, a Estação de Tratamento de Chorume (ETC) transforma o líquido tóxico em água de reuso e o biogás será transformado em energia e convertido em créditos de carbono. A ETC tratará, em pleno funcionamento, dois mil metros cúbicos do efluente por dia.

Atualmente, o aterro produz por dia $450 \mathrm{~m}^{3}$ de chorume ou o equivalente a 15 caminhões de resíduos líquidos. Após tratamento preliminar, 30\% efluente é transportado para a central de tratamento de esgoto de Alegria, da Cedae, no Caju. Os 70\% restantes seguem para a empresa privada Águas de Niterói.

A Central de Tratamento de Resíduos de Seropédica é uma concessão da COMLURB a Ciclus e além dos resíduos da Cidade, atende também os municípios de Itaguaí, Seropédica e Mangaratiba. Este grupo de municípios ainda não possui consórcio formalizado (PMGIRS/RJ, 2013).

Para a coleta seletiva, utiliza-se somente uma unidade das 6 previstas no PMGIRS/RJ. De acordo com informações obtidas através pesquisas de campo conforme detalhado no Apêndice 6.1, a Unidade de Irajá inaugurada em janeiro de 2014, processa no máximo 20 ton/dia, gerando ainda baixos resultados. O sistema conta também com a Usina do Caju, porém não há informações sobre as quantidades enviadas originadas da coleta seletiva para esta unidade.

A quantidade de recicláveis recuperada pelo sistema de coleta seletiva e pelas cooperativas de catadores atingiu 7.797 toneladas em todo o ano de 2011. Isto equivale a apenas $4 \mathrm{~g}$ por pessoa por dia, gerando um 
percentual de $1 \%$ frente ao total de itens recicláveis gerados no ano (PMGIRS, 2013).

\begin{tabular}{|c|c|c|}
\hline UNIDADE & $\begin{array}{c}\text { Capacidade } \\
\text { (ton/dia) }\end{array}$ & Situação \\
\hline ETR Caju & & Em operação. Recebe pequena parte dos resíduos. \\
\hline Triagem Irajá & 30 & Em operação. Recebe aproximadamente 20ton/dia. \\
\hline Bangu & 30 & Em finalização de obras. Prev. de inauguração em 2014 \\
\hline Centro & 30 & Em finalização de obras. Prev. de inauguração em 2015. \\
\hline Campo Grande & 30 & Em liberação de licenças. \\
\hline Jacarepaguá & 30 & Em definição de local para operar. \\
\hline Penha & 30 & Em definição de local para operar. \\
\hline Total & 120 & \\
\hline
\end{tabular}

Tabela 31 - Unidades de Separação de resíduos da coleta seletiva no município. Fonte: Adaptado de entrevistas realizadas na Comlurb e visitas técnicas (2014).

A partir do indicador acima, que encontra-se abaixo das meta de $5 \%$ determinada pelo PMGIRS/RJ (2013), pode-se perceber que o processo ainda está em fase inicial, apresenta alguns pontos de melhoria e desafios a cumprir, que serão detalhados a seguir.

O PMGIRS prevê a ampliação da coleta seletiva através do Programa de Ampliação da Coleta Seletiva da Cidade. Para sua viabilização, estão destinados 52 milhões de reais conforme acordo assinado entre a Prefeitura do Rio de Janeiro e o BNDES, em dezembro de 2010.

O Programa objetiva estender os serviços a todos os 160 bairros da Cidade, promovendo a inclusão social e produtiva de ate 1.500 catadores de materiais recicláveis e garantindo o reaproveitamento de $5 \%$ dos materiais potencialmente recicláveis presentes no lixo domiciliar.

Estão previstas também campanhas de educação ambiental, ações nas escolas, condomínios, associações de moradores, síndicos e sindicato de porteiros. Propagandas em mídia exterior (outdoor; cinemas de bairro, busdoor e banners no metrô e Supervia, inserção em TVs aberta e fechada, revistas e jornais) e a realização de eventos também estão previstas neste programa.

O PMGIRS também envolve a desoneração da cadeia produtiva da reciclagem, comentando a criação de um Projeto de Lei que objetiva a isenção de IPTU Imposto Predial e Territorial Urbano para as empresas destinadas ao beneficiamento/reaproveitamento de materiais recicláveis. O projeto, redigido com o apoio da Secretaria Municipal de Fazenda, apresentada e aprovada na Reunião Ordinária do CONSEMAC de 12/06/2012 encontra-se em processo de aprovação.

Além disso, O CONSEMAC, através da Câmara Setorial Permanente de Resíduos, coordenada pela SMAC, tem dado andamento a propostas que visem a valorização de materiais reciclados na cadeia produtiva da reciclagem. 
A obrigatoriedade de uso de artefatos reciclados de resíduos da construção civil em obras da administração pública municipal, a utilização de misturas asfálticas contendo borracha de pneumáticos inservíveis na pavimentação de vias e rodovias municipais e o incentivo ao reaproveitamento de cascas de coco verde, são alguns exemplos destes mecanismos propostos.

Além das ações acima, o plano também cita diversos programas de incentivo à cadeia de reciclagem e envolvimento com diversos atores da sociedade, como o Projeto Coco Zero, Programa de Coleta Seletiva Solidária da Prefeitura, criado pelo Decreto Municipal no 30.624/2009, programas e ações de educação ambiental, envolvimento com comunidades, sociedades organizadas, dentre outros.

Atualmente, a coleta de recicláveis baseia-se principalmente no modelo porta a porta. De acordo com entrevistas realizadas na Comlurb, conforme detalha os Apêndices 6.1, 6.2 e 6.4, o Rio de Janeiro iniciou o processo com pontos de entrega voluntária (PEV`s), que foram reduzindose aos poucos.

O sistema atende os principais logradouros de 41 dos 160 bairros do Município, utilizando 16 veículos, 3 destes classificados como baús e 13 veículos compactadores.

Ainda de acordo com entrevistas e pesquisas de campo, a baixa aceitação da população e consequente volume reduzido de resíduos recicláveis na coleta, geram um sistema logístico sem um fluxo definido para o envio dos resíduos coletados. Diariamente, analisa-se o volume do lixo recebido, definindo seu envio para as 2 centrais em funcionamento (Irajá ou Caju) ou demais cooperativas cadastradas.

Devido à falta de alguns documentos exigidos por empresas e órgãos públicos, poucas cooperativas conseguem coletar o lixo reciclável destas organizações. O Pólo de Gramacho, coleta resíduos de somente 2 (duas) empresas. Mesmo situando-se próximo à Refinaria de Duque de Caxias, ainda não foi possível coletar os resíduos originados desta empresa. O próprio BNDES, instituição que tem dado apoio financeiro aos programas de reciclagem entrega somente copos plásticos a este Pólo.

A Central de Triagem de Irajá também enfrenta os mesmos desafios do Pólo de Gramacho e sua principal fonte de resíduos são os originados do processo de coleta seletiva, sem nenhuma parceria firmada com empresas e órgãos públicos, devido a processos burocráticos existentes nestas organizações.

\subsubsection{Objetivos e Metas}

O município do Rio de Janeiro possui alguns norteadores para a política de gestão de resíduos sólidos. Além da PNRS (2012) e o plano estadual, 
o PMGIRS/RJ (2013) detalha as metas para o município, data das até 2020, conforme Tabela 33 a seguir.

Além destes, segue também as metas de redução de emissões antrópicas de GEE, de acordo com a Lei Municipal no 5.248, de 27.01.2011, que estabelece estes valores em seu artigo 6을 em relação ao nível de emissões no município em 2005: redução de 8\% para ano de 2012; redução de $16 \%$ até o ano de 2016 e $20 \%$ das emissões até 2020.

As metas do plano municipal complementam os objetivos definidos na PNRS (2012), as metas citadas no Plano de Resíduos Sólidos ainda que não aprovados em todas as camadas e o plano estadual.

Estas, que deveriam ser mais diretas às atividades do município, que apresentam índices ainda muito gerais. Como exemplo, não citam pontos como o aproveitamento energético e desenvolvimento de PEV's.

\begin{tabular}{|c|c|c|c|}
\hline METAS & Até final 2013 & Até final 2016 & Até final 2020 \\
\hline $\begin{array}{l}\text { Desenvolver e implantar projetos de destinação final, } \\
\text { ambientalmente sustentáveis, visando atingir o Indice de } \\
\text { Qualidade de Aterros de Resíduos IQR, maior ou igual a 8,1, } \\
\text { correspontentes às condiçő̃es adequadas até } 2013 \text { conforme } \\
\text { consta no Plano Plurianual 2010-2013 da PCRJ, adotando } \\
\text { medidas preventivas e corretivas para garantir a manutenção } \\
\text { do indice acima do estabelecido. }\end{array}$ & $\begin{array}{c}100 \% \text { dos RSU } \\
\text { encaminhados } \\
\text { ao CTR-Rio }\end{array}$ & $\begin{array}{c}100 \% \text { dos RSU } \\
\text { encaminhados ao CTR- } \\
\text { Rio }\end{array}$ & $\begin{array}{l}100 \% \text { dos RSU } \\
\text { encaminhados } \\
\text { ao CTR-Rio }\end{array}$ \\
\hline $\begin{array}{c}\text { Garantir que os resíduos sólidos das atividades de poda da } \\
\text { arborização municipal tenham destinação ambientalmente } \\
\text { adequada, com enfase na compostagem e no seu } \\
\text { aproveitamento energético, desde que identificada alternativa } \\
\text { técnica ou ambientalmente viável. }\end{array}$ & - & $\begin{array}{l}50 \% \text { dos resíduos } \\
\text { gerados }\end{array}$ & $\begin{array}{l}100 \% \text { dos } \\
\text { resíduos } \\
\text { gerados }\end{array}$ \\
\hline $\begin{array}{c}\text { Realizar o mapeamento das áreas degradadas pela disposição } \\
\text { irregular de resíduos sólidos urbanos, resíduos da construção } \\
\text { civil entre outros, providenciando o encerramento do } \\
\text { vazamento irregualr e responsabilizando o autor da degradação } \\
\text { para recuperação da área. } \\
\end{array}$ & - & $\begin{array}{l}\text { Realizar o } \\
\text { mapeamento das } \\
\text { áreas degradadas }\end{array}$ & $\begin{array}{l}\text { Promover a } \\
\text { recuperação/re } \\
\text { mediação das } \\
\text { áreas listadas. }\end{array}$ \\
\hline $\begin{array}{c}\text { Garantir que a frota terceirizada de veículos de limpeza urbana } \\
\text { da Cidade operem com combustíveis renováveis ou híbridos, } \\
\text { desde que identificada alternativa técnica, econômica e } \\
\text { ambientalmente viável. }\end{array}$ & $\begin{array}{l}10 \% \text { da frota } \\
\text { terceirizada }\end{array}$ & $\begin{array}{l}70 \% \text { da frota } \\
\text { terceirizada }\end{array}$ & $\begin{array}{c}100 \% \text { da frota } \\
\text { terceirizada }\end{array}$ \\
\hline $\begin{array}{c}\text { Coleta seletiva da fração orgânica e respectivo tratamento, } \\
\text { desde que identificada alternativa técnica, econômica e } \\
\text { ambientalmente viável. }\end{array}$ & - & $10 \%$ da fração orgânica & $\begin{array}{c}100 \% \text { da fração } \\
\text { orgânica }\end{array}$ \\
\hline $\begin{array}{c}\text { Coletar os materiais reciclávéis da Cidade, conforme consta no } \\
\text { plano Plurianual 2013-2016 da PCRJ , com ênfase na } \\
\text { identificação de alternativa técnica, econômica e } \\
\text { ambientalmente viável. }\end{array}$ & \begin{tabular}{|c|}
$5 \%$ dos \\
materiais \\
recicláveis de \\
$\begin{array}{c}\text { origem } \\
\text { domiciliar }\end{array}$
\end{tabular} & $\begin{array}{l}25 \% \text { dos materiais } \\
\text { recicláveis de toda a } \\
\text { cidade, incluindo } \\
\text { atividades públicas e } \\
\text { privadas }\end{array}$ & - \\
\hline
\end{tabular}

Tabela 32 - Metas definidas no PMGIRS do município.

Fonte: P MGIRS/RJ, 2013. 


\subsubsection{Análise geral da Gestão de RSU no município do Rio de Janeiro - Matriz FOFA/SWOT}

A gestão de resíduos no município do Rio de Janeiro está pautada na destinação de grande parte dos resíduos ao aterro sanitário de Seropédica com aproveitamento de biogás e na coleta seletiva para desenvolvimento do mercado de reciclagem através de cooperativas de catadores, pontos que podem apresentar riscos para atendimento às metas definidas, nos prazos determinados por estas.

Para melhor visualização do cenário do município no que diz respeito à Gestão de RSU, este estudo apresenta a análise a partir da Matriz FOFA/SWOT, uma metodologia de análise de cenários.

De acordo com LINDON et. al (2004), a Matriz SWOT conforme conhecida originalmente e FOFA, sua tradução à Língua Portuguesa analisa o cenário escolhido de acordo com 4 parâmetros: Streghts (Forças), Weaknesses (Fraquezas), Opportunities (Oportunidades) e Threats (Ameaças).

As forças e fraquezas são relacionadas aos pontos de análise internas, diretamente ligadas ao objeto de análise. Neste caso, a gestão de RSU do município do Rio de Janeiro.

As oportunidades e ameaças são fatores relacionados ao ambiente externo. Neste caso, são analisados os pontos representativos para a gestão de RSU do município de acordo com as Políticas e ações brasileiras ou mundiais.

Desta forma, a Matriz FOFA/SWOT representada na Tabela 33 apresenta uma descrição resumida dos fatores levantados para análise do cenário carioca, avaliando riscos e oportunidades do modelo atual de gestão de resíduos sob a ótica dos objetivos ambientais, definidos através da PNRS e seus desdobramentos estaduais e municipais.

\begin{tabular}{l} 
FORÇAS \\
\hline Abrangência da coleta de RSU em todos os logradouros. \\
Eliminação de lixões. \\
Geração de biogás a partir dos aterros. \\
PMGIRSU/RJ divulgado e em andamento. \\
Existência de comercialização de composto, ainda que baixo. \\
Existência de comercialização de CDR, ainda que baixo. \\
Visibilidade do municipio frente aos demais do Brasil. \\
\hline \multicolumn{1}{c|}{ OPORTUNIDADES } \\
\hline Mercado de reciclagem crescente. \\
Novas tecnologias triagem do lixo com retorno em curto prazo. \\
Existência de mercado para biogás e CDR. \\
Oportunidades de investimento para novas tecnologias. \\
PNRS divulgada e em andamento. \\
Novas oportunidades de mercado e empregos.
\end{tabular}

Tabela 33 - Matriz SWOT/FOFA.

\section{FRAQUEZAS}

Reciclagem dependente da coleta seletiva. Baixo nivel de abrangência da coleta seletiva. Altos custos logisticos e investimento envolvidos para a coleta seletiva. Baixo nível de conhecimento dos catadores. Baixo nível de comprometimento dos catadores. Alto volume de resíduos enviado aos aterros sanitários. Impactos ambientais e custos representativos envolvidos ao grande volume de resíduos enviado aos aterros. Não atendimento da hierarquia de destinação de resíduos conforme PNRS.

\section{AMEAÇAS}

Falta de interação entre gestores municipais.

Falta de visão sistêmica aos gestores municipais.

Gestão pública sem continuidade de ações entre mandatos.

Baixo nível de envolvimento da população.

Altos custos e investimentos envolvidos na implantação de novas tecnologias.

Novas tecnologias pouco difundidadas, baixo know how das empresas e especialistas. Altos custos envolvidos para a comercialização de materiais reciclados. 


\section{FORCAS E OPORTUNIDADES}

O município apresenta rota para coleta do RSU gerado no município a todos os logradouros, garantindo a destinação ambientalmente correta para quase todos os resíduos gerados, ainda que esta seja em sua maioria o envio a aterros sanitários.

Ainda com relação à destinação final, o município mantém em funcionamento somente Aterros Sanitários e controla os impactos ambientais gerados a partir dos aterros controlados e lixões, com suas atividades já finalizadas. A partir destes, obtém e comercializa o biogás gerado, com mercado já desenvolvido para a utilização deste produto.

Apresenta-se também como força a publicação e andamento do PMGIRS, um norteador de ações, controlador de metas e fomentador de novos planos para cada sub prefeitura.

Com relação a outros tipos de destinação de resíduos, a cidade já apresenta, mesmo que em pequenas proporções, a geração e comercialização de composto e CDR, o que facilita o desenvolvimento de processos, visando o aumento do volume destes produtos.

Por ser uma das cidades de maior visibilidade mundial e de população representativa, o município apresenta maiores facilidades políticas na obtenção de investimentos e desenvolvimento de projetos, bem como maior número de oportunidades no mercado de reuso e reciclagem.

O cenário brasileiro e mundial é favorável para o desenvolvimento de ações ambientais, já que os indicadores têm forçado os gestores públicos e provados para ações para de melhoria do Meio Ambiente. Desta forma, não faltam tecnologias disponíveis para o tratamento de lixo urbano, bem como estudos desenvolvidos e em andamento.

Algumas tecnologias já testadas, como o TMB objeto deste estudo, apresentam ganhos imediatos no que diz respeito à geração de material reciclável seco e orgânico.

Além disso, o mercado consumidor tem aceitado ou até mesmo buscado produtos de cunho ambiental, fomentando a geração de novo um mercado, com oportunidades para a comercialização de resíduos e geração de emprego. Tal ponto é válido tanto para a comercialização de reciclados, bem como para o biogás, CDR e composto.

A publicação da PNRS também se mostra como uma oportunidade neste cenário, já que é o norteador para as demais ações em níveis estaduais e municipais, fomentando a geração deste novo mercado. 


\section{FRAQUEZAS E AMEAÇAS}

Ainda que o município esteja sendo atendido por diversas políticas e projetos visando a melhoria da gestão de RSU, os resultados ainda são muito baixos.

O modelo de gestão de RSU definido no Plano ainda não atende a hierarquia de aproveitamento de resíduos definida na PNRS, baseandose em aterros como principal destinação de resíduos e na reciclagem dependente da coleta seletiva.

Conforme comentado em capítulos anteriores, a coleta seletiva apresenta fraquezas que são fatores críticos para o sucesso da reciclagem. A mudança de cultura da sociedade e custos logísticos envolvidos são pontos que demandarão tempo para apresentarem resultados satisfatórios.

O mesmo vale para os resíduos orgânicos, que também apresentam baixo nível de tratamento, ainda sem previsão para ações de curto prazo definidos na PMGIRS, não respeitando a hierarquia definida na PNRS.

Além disso, a baixa preparação dos catadores para assumir boa parte da cadeia na geração de material para a reciclagem também apresenta riscos.

O mercado de tratamento de lixo ainda está em desenvolvimento, apresentando potencial para crescimento, com consequente geração de emprego e renda. Por outro lado, também apresenta dificuldades no que envolve a gestão pública brasileira, pautada em ações de curto prazo, baixa visão sistêmica e pouca interatividade entre as localidades.

Devido à importância do mercado de tratamento de RSU em várias localidades ao redor do mundo, algumas tecnologias têm surgido, embora ainda apresentem altas barreiras de entrada, pois exigem investimento alto e pessoal capacitado para operação, gerando custos à atividade, podendo assim reduzir sua viabilidade econômica.

A bi tributação encontrada nos materiais reciclados, os entraves burocráticos para a destinação de resíduos tanto em órgãos públicos como em organizações particulares também apresentam-se como ameaças ao desenvolvimento de ações para aproveitamento de resíduos.

Tal estudo de cenário a partir da Matriz SWOT/FOFA apresenta pontos favoráveis à implantação da tecnologia estudada para o município do Rio de Janeiro, que será detalhada no Capítulo 4. 


\subsubsection{Estudo de Caso - Usina do Caju}

A Usina, inaugurada em 1992, fechada por um período e voltando a funcionar em 2000, processa diariamente 3.500 toneladas de resíduos, sendo que $10 \%$ deste volume recebido é utilizado nos processos para reaproveitamento e $90 \%$ segue para o Aterro Sanitário de Seropédica, que utiliza 200 carretas/dia para a triagem.

Dos $10 \%$ processados internamente, $51,7 \%$ do volume vai para a produção de CDR, 36,4\% na compostagem, 8,7\% na separação para a reciclagem (SPR), restando $3,2 \%$ de rejeitos.

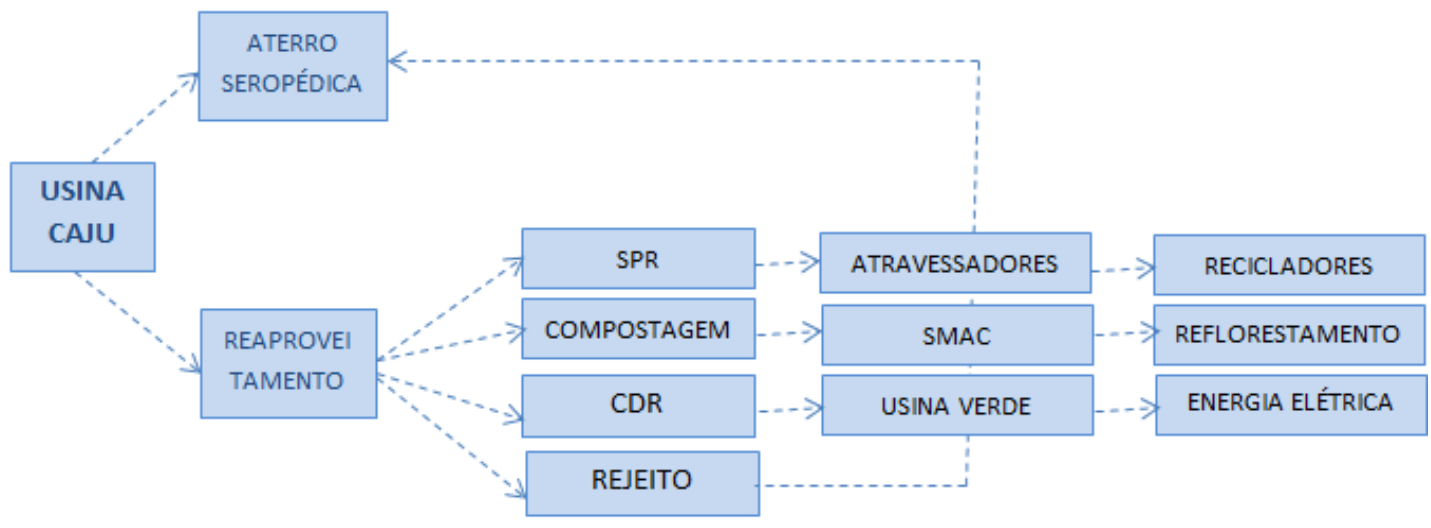

Figura 53 - Fluxo logístico de resíduos na Usina do Caju. Fonte: Visita técnica, 2014.

Em 2012, foram gerados $15.000 \mathrm{~m}^{3}$ de composto, comercializado principalmente à SMAC (Secretaria Municipal de Meio Ambiente), que utiliza o composto para reflorestamento e contenção de encostas, o maior projeto de replantio nas encostas do Mundo.

O volume de CDR é coletado pela Usina Verde SA, para geração de Energia Elétrica. Esta empresa é de capital privado, localizada no Campus da UFRJ - Fundão, com o objetivo de implantar de soluções ambientais, em especial para o tratamento de resíduos sólidos através de Usinas de Recuperação Energética (URE).

Além dos ganhos acima, o processo de separação para a reciclagem (SPR) apresenta ganhos importantes, principalmente se considerarmos a estrutura e baixos recursos orientados para este. O objetivo deste estudo de caso é a avaliação deste processo, avaliando este local como uma futura unidade para utilizar o tratamento mecânico e biológico, tema de estudo desta dissertação.

Considerando que a Usina recebe 3.500 ton/dia, encaminha $10 \%$ deste volume para os processos de reaproveitamento, sendo $8,7 \%$ deste 
resultado originado do SPR, é possível calcular-se que a Usina gera os mesmos $1 \%$ de itens para a reciclagem, assim como a coleta seletiva.

O mesmo percentual obtido envolve menos custos logísticos, já que o resíduo é originado através da coleta de RSU, utilizando-se a mesma estrutura.

Na Separação para Reciclagem, a Comlurb conta com razoável estrutura de equipamentos e de pessoas. Toda a operação é realizada pela Cooperativa Transformando, sob supervisão e gestão da Comlurb, localizada dentro da Usina do Caju, a qual possui 120 cooperados.

A função dos cooperados é separar manualmente os itens recicláveis, prensando-os e comercializando-os para os atravessadores, que coletam os resíduos de sua responsabilidade.

A receita obtida através da comercialização dos resíduos é dividida entre os cooperados de acordo com a produtividade de cada um, apresentando lucratividade média mensal de $R \$ 140.000,00$, gerando aproximadamente $\mathrm{R} \$ 1.160,00$ de remuneração mensal aos cooperados.

A Comlurb direciona os resíduos para este processo de acordo com as rotas dos veículos, originadas de locais com geração de lixo de melhor qualidade (maior quantidade de lixo não orgânico, melhor separado normalmente originado da Zona Sul).

Descrição geral do processo:

\begin{tabular}{|c|c|c|}
\hline ETAPA & $\begin{array}{l}\text { PISO DA } \\
\text { USINA }\end{array}$ & DESCRIÇÃO \\
\hline $\begin{array}{l}\text { PESAGEM DE } \\
\text { ENTRADA DO } \\
\text { VEÍCULO }\end{array}$ & $10 \mathrm{PISO}$ & $\begin{array}{l}\text { Pesagem inicial do veículo, identificação da rota de } \\
\text { coleta e motorista. }\end{array}$ \\
\hline FOSSO & $1 \stackrel{0}{ } \mathrm{PISO}$ & 2 fossos para armazenagem dos resíduo \\
\hline GARRA COLETORA & 1ํ PISO & $\begin{array}{c}\text { Garra que busca os resíduos armazenados no } \\
\text { fosso, levando-os ao rasga sacos. }\end{array}$ \\
\hline RASGA SACO & $1 \cong \mathrm{PISO}$ & Rasga sacos e homogeiniza o lixo. \\
\hline 1ㄹ CRIVO & $1 \stackrel{0}{ } \mathrm{PISO}$ & $\begin{array}{c}\text { Descarte manual de itens de grande proporção, } \\
\text { que possam vir a travar o processo (esteira, } \\
\text { peneira, outros). }\end{array}$ \\
\hline $\begin{array}{l}\text { ESTEIRA DE } \\
\text { TRANSPORTE }\end{array}$ & TRANSIÇÃO & Esteira mecânica, para transporte do lixo. \\
\hline $\begin{array}{l}\text { ESTEIRA DE } \\
\text { SEPARAÇÃO }\end{array}$ & $2^{\circ} \mathrm{PISO}$ & $\begin{array}{l}\text { Esteira mecânica, para coleta manual dos itens } \\
\text { através dos cooperados. }\end{array}$ \\
\hline ELETROÍMA & $2^{\circ} \mathrm{PISO}$ & $\begin{array}{c}\text { Separação de metais e reenvio de resíduos à } \\
\text { esteira manual. }\end{array}$ \\
\hline TROMMEL & $2^{\circ} \mathrm{PISO}$ & $\begin{array}{l}\text { Separação de itens por tamanho do resíduo e } \\
\text { reenvio à esteira manual. }\end{array}$ \\
\hline $\begin{array}{l}\text { PESAGEM } \\
\text { UNITÁRIA }\end{array}$ & $2^{\circ} \mathrm{PISO}$ & $\begin{array}{l}\text { Envio manual de carrinhos à pesagem para } \\
\text { medição de produtividade dos cooperados. }\end{array}$ \\
\hline $\begin{array}{c}\text { DUTO DE } \\
\text { TRANSPORTE }\end{array}$ & TRANSIÇÃO & $\begin{array}{c}\text { Colocação da quantidade pesada na fase acima } \\
\text { em dutos diferenciados por tipo de resíduo. }\end{array}$ \\
\hline $\begin{array}{l}\text { AGRUPAMENTO DE } \\
\text { RESÍDUOS }\end{array}$ & $1 \stackrel{\circ}{P I S O}$ & $\begin{array}{c}\text { Armazenagem e acréscimo de valor dos resíduos } \\
\text { (agrupamento por cor, tipo) }\end{array}$ \\
\hline PRENSAGEM & 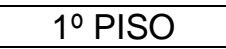 & Prensagem de resíduos, transformando-os em \\
\hline
\end{tabular}




\begin{tabular}{|c|c|c|}
\hline & & fardos. \\
\hline ARMAZENAGEM & $1^{\circ}$ PISO & $\begin{array}{c}\text { Colocação dos fardos em contêineres } \\
\text { armazenadores de propriedade dos } \\
\text { atravessadores. }\end{array}$ \\
\hline $\begin{array}{c}\text { CONTATO } \\
\text { ATRAVESSADORES }\end{array}$ & $1^{\circ}$ PISO & Agendamento para a coleta dos contêineres. \\
\hline $\begin{array}{c}\text { PESAGEM DE SAÍDA } \\
\text { DO VEÍCULO }\end{array}$ & $1^{\circ}$ PISO & $\begin{array}{c}\text { Pesagem para geração do valor de venda a ser } \\
\text { cobrado ao atravessador. }\end{array}$ \\
\hline
\end{tabular}

Tabela 34 - Descrição de processos - Usina do Caju.

A maioria dos veículos que chegam à Usina do Caju despejam seus resíduos em um armazém para unificação e novo carregamento aos veículos que se destinam à CTR-Rio.

Os veículos para despejo de resíduos no fosso, utilizados no SPR são selecionados no momento da pesagem, quando identifica-se a origem dos locais de coleta e qualidade do lixo.

Após coletados através da garra, passam pela sequência de processos descritos na tabela acima, ficando separados em bag's, transportados para os armazéns, onde sofrem nova separação (como exemplo, a diferenciação de cores para o PET), são prensados e armazenados nos containers dos atravessadores, localizados no pátio da Usina.

No mesmo piso das esteiras, localizam-se também um separador magnético e um trommel, também utilizados na separação dos itens recicláveis, porém não foi possível obter informações sobre sua produtividade e operação dos equipamentos durante as visitas e entrevistas. Estes também são direcionados para dutos específicos, sendo armazenados em bag's e encaminhados aos containers dos atravessadores.

Uma outra equipe de cooperados é responsável pelo contato com os atravessadores, que acertam o valor de venda, a data de coleta dos containers cheios e entrega dos vazios.

Todos os postos de trabalho são identificados para medição de produtividade e posterior pagamento aos cooperados, após recebimento do pagamento pelos atravessadores.

Alguns funcionários da Comlurb acompanham o processo produtivo, orientam e coordenam o processo produtivo.

\section{Vantagens e oportunidades identificadas}

A Usina detém espaço e processo desenvolvido para utilização do lixo orgânico, o que fortalece a utilização do processo atual, obtendo bons resultados tanto na compostagem, como no CDR e comercialização do lixo reciclável a partir da coleta domiciliar, ao contrário das demais Unidades de Triagem do Rio de Janeiro e de outras cidades brasileiras. 
Devido ao espaço disponível e parte da estrutura desenvolvida, este local poderia ser utilizado para a instalação de uma unidade de TMB ou modernização da planta, reduzindo o investimento necessário se comparado à criação de uma unidade TMB num terreno sem nenhuma estrutura.

Esta unidade também apresenta boa localização, facilitando o fluxo logístico, pois fica próxima à Avenida Brasil, uma das principais vias do Rio de Janeiro.

Além dos pontos levantados acima, uma grande vantagem observada no processo é a orientação dos profissionais da Comlurb aos catadores que trabalham nesta unidade, melhorando os índices de produtividade e qualidade do processo.

Conforme comentado em capítulos anteriores, a PNRS (2012) incentiva o envolvimento com cooperativas na gestão de resíduos. Visando a redução de custos e facilidade no processo, as Prefeituras não só tem envolvido as cooperativas, como têm também passado toda a responsabilidade a estas organizações.

Tal ponto é demasiadamente arriscado, pois fatores como avaliação e gestão de processo, relacionamento comercial, captação de recursos, manutenção dentre outros pontos requerem conhecimento e experiência técnica, competência que os catadores não detêm, já que a maioria possui somente o ensino fundamental.

O incentivo ao emponderamento fomentado pela PNRS (2012) é importante, porém a responsabilidade sob estes processos deve ser passada gradativamente e não realizada conforme a maioria das Prefeituras têm feito.

$\mathrm{Na}$ Usina do Caju, os funcionários gerenciam o processo produtivo, trabalham com gestão de $\mathrm{RH}$ e orientam os catadores em alguns processos.

\section{Desafios e problemas encontrados no processo}

A Usina possui baixos recursos direcionados à Manutenção, insuficientes para melhorias de processo e aumento de produtividade. Há a necessidade de maior investimento para modernização dos equipamentos e consequentemente aumento da produtividade e aproveitamento dos resíduos. 
Mesmo apresentando resultados positivos se comparados à coleta seletiva, compostagem e CDR, a Unidade processa somente $10 \%$ do volume coletado, enviado mais de 7.000ton/dia de resíduos para o aterro.

Para a compostagem, é importante o investimento em locais para armazenamento do composto, que atualmente ficam localizados a céu aberto, demandando maior tempo para a formação do composto, sujeitos a variações do clima, gerando retrabalho.

Tal resultado pode ser melhorado com maior direcionamento de investimento tanto em equipamentos como em pessoal. Para os equipamentos, novamente a implantação de uma unidade de TMB mostra-se favorável, tanto na separação quanto no tratamento biológico dos resíduos.

No investimento em pessoal, o processo apresenta possibilidade para a contratação de mais cooperados, melhorando 0 atendimento aos objetivos da Política Nacional e Plano Estadual de Resíduos.

O nível de conhecimento dos cooperados apresenta-se novamente, como ponto negativo. Mesmo com a gestão da Comlurb em algumas fases do processo, como a triagem inicial e controle de produtividade dos catadores, tal ponto não é suficiente.

Muitos resíduos de alto valor no mercado da reciclagem são desperdiçados, seguindo para a compostagem ou CDR, gerando menor rentabilidade e produtividade no processo.

Os cooperados, pelo baixo nível de instrução e treinamento, identificam como importantes somente os resíduos que apresentam compradores e não possuem equipes para captação de novos clientes. 


\section{A UTILIZAÇÃO DO TMB NO RIO DE JANEIRO}

Boa parte das dificuldades encontradas para o cumprimento das metas ambientais do município do Rio de Janeiro está ligada à destinação de resíduos secos e úmidos para a reciclagem ou reuso, bem como o cumprimento da hierarquia definida na PNRS (2010), conforme apresentado na análise de cenário, utilizando a Matriz SWOT/FOFA, descrita no Capítulo 3.

Os pontos levantados na Matriz SWOT/FOFA podem ser mitigados com a inclusão de um processo de tratamento mecânico e biológico na gestão de resíduos do município.

A redução do volume de lixo enviado ao aterro gera ganhos logísticos importantes, como a redução de gastos com combustível, manutenção veículos e redução da frota de veículos para coleta e triagem. Além disso, há também o ganho de tempo de vida no aterro e menor emissão de $\mathrm{CO}_{2}$ pela redução do número de viagens para disposição final dos resíduos.

Conforme abordado no Capítulo 2, esta tecnologia traz inúmeras vantagens, porém sua viabilidade deve ser analisada de acordo com o perfil de cada localidade, conforme será abordado neste Capítulo.

Para tal aplicação ao município do Rio de Janeiro, o estudo utilizará uma metodologia criada pelo autor, baseando-se numa análise empírica para a comparação de 2 (dois) cenários, considerando 15 (quinze) fatores críticos e 3 (três) critérios para avaliação de cada fator crítico.

Os cenários avaliados e suas formas de tratamento dos resíduos são detalhados conforme a seguir.

- Cenário 1 - SITUAÇÃO ATUAL - 90\% do volume de RSU enviado para o aterro sanitário, $10 \%$ tratado de acordo com técnicas já descritas no Capítulo $3,1 \%$ dos resíduos secos enviado à reciclagem através coleta seletiva.

- Cenário 2 - SITUAÇÃO PROPOSTA - destinação de 50\% dos RSU do município à Unidade TMB, mantendo os demais $50 \%$ conforme o tratamento e destinação utilizados atualmente.

Mesmo ainda mantendo $50 \%$ dos resíduos com destinação não condizentes com a PNRS (2010), tal opção já se apresenta como uma melhoria ao cenário atual, reduzindo substancialmente o volume enviado ao aterro sanitário. Escolheu-se o tratamento de apenas $50 \%$ na Unidade TMB, considerando tanto fatores financeiros como operacionais.

A Unidade de TMB do cenário proposto seguirá nos moldes do Estudo de Caso Valnor, que será abordado no Capítulo 4.1: utilização de equipamentos para tratamento mecânico e unidade de lavagem de embalagens para valorização dos resíduos secos e 
tratamento biológico para os resíduos orgânicos a partir da compostagem e digestão anaeróbia.

Considera-se também a mesma proporção dos produtos gerados no tratamento de resíduos do Caso Valnor, que será descrito no Apêndice 5.2: $30 \%$ de CDR, $9 \%$ de composto, $12 \%$ de embalagens para a reciclagem e geração do biogás a partir do volume enviado à Digestão Anaeróbica.

É importante considerar que as proporções utilizadas acima são relacionadas ao processo de separação, de acordo com o percentual de lixo orgânico e reciclável brasileiro. Desta forma, o resultado nominal brasileiro continuará sendo menor que o europeu, devido às diferenças proporcionais dos resíduos.

Mesmo neste modelo, o volume de perda ainda soma $45 \%$, já que os dados divulgados pela Valnor utilizados no Estudo de Caso 4.1 são relativos ao ano de 2013 e ainda não computavam a implantação da unidade de lavagem de embalagens. Desta forma, a proporção de resíduos secos para envio à reciclagem pode ser considerada acima de $12 \%$.

Os fatores críticos utilizados na metodologia de análise são listados conforme a Tabela 35 a seguir.

Os critérios para avaliação de cada fator crítico são definidos conforme seu nível de adequação às políticas ambientais ou de acordo com o tempo necessário para o cumprimento de metas.

- Critério com conceito 1 - totalmente adequado às políticas ambientais ou atendimento de metas em curto prazo;

- Critério com conceito 2 - adequado parcialmente às políticas ambientais ou com atendimento a metas em médio prazo;

- Critério com conceito 3 - baixa adequação às políticas ambientais ou atendimento de metas em longo prazo.

Para a obtenção da conceituação final, quanto maior a pontuação total menos adequado estará o cenário avaliado, de acordo com os fatores críticos e consequentemente às políticas ambientais exigidas.

De acordo com os fatores críticos analisados, o cenário proposto com utilização do TMB para tratamento de $50 \%$ dos RSU apresenta maior nível de adequação às políticas ambientais do que o cenário atual, conforme será detalhado a seguir. 
FATORES CRÍTICOS

\begin{tabular}{|c|c|}
\hline 1 & Custo logístico \\
\hline 2 & Emissões GEE`s \\
\hline 3 & Investimento tecnológico \\
\hline 4 & Investimento em conscientização \\
\hline 5 & Volume enviado ao aterro \\
\hline 6 & $\begin{array}{l}\text { Custos remediação do aterro pós } \\
\text { fechamento }\end{array}$ \\
\hline 7 & Custo tratamento de chorume \\
\hline 8 & Tempo duração do aterro \\
\hline 9 & Geração do biogás \\
\hline 10 & $\begin{array}{l}\text { Nível de conhecimento exigido para a } \\
\text { operação }\end{array}$ \\
\hline 11 & Nível de envolvimento político \\
\hline 12 & Cumprimento do índice de reciclagem \\
\hline 13 & Cumprimento da hierarquia resíduos \\
\hline 14 & $\begin{array}{l}\text { Cumprimento da meta para } \\
\text { envolvimento de catadores }\end{array}$ \\
\hline 15 & $\begin{array}{l}\text { Retorno à rentabilidade do negócio para } \\
\text { os catadores, anteriormente obtida com } \\
\text { a catação }\end{array}$ \\
\hline & TOTAL \\
\hline
\end{tabular}

Tabela 35- Fatores críticos para análise de cenários.

A pontuação total poderá atingir no mínimo 15 pontos (cenário totalmente adequado) e máximo de 45 pontos (cenário com baixa adequação), conforme demostra a Figura 54 a seguir.

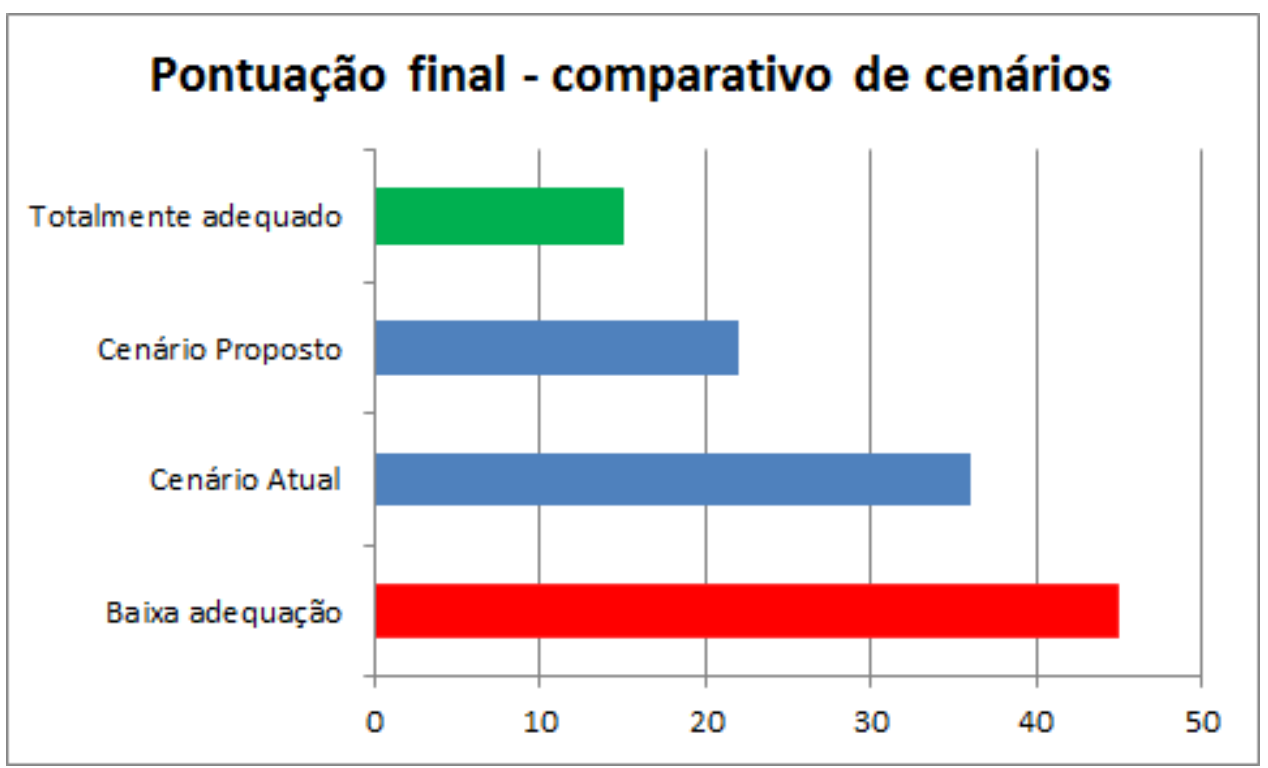

Figura 54 - Comparativo de pontuações finais obtidas de acordo com a metodologia de análise aplicada no estudo. 
A aplicação da metodologia descrita ao cenário atual e o proposto, resulta na Tabela 36.

\begin{tabular}{|c|c|c|c|}
\hline \begin{tabular}{c|} 
FATORES \\
CRITTICOS \\
METODOLOGIAS \\
DE \\
TRATAMENTO \\
RSU
\end{tabular} & $\begin{array}{c}\text { SITUAÇÃO } \\
\text { ATUAL }\end{array}$ & $\begin{array}{c}\text { SITUAÇÃO } \\
\text { PROPOSTA } \\
\text { TMB, } \\
\text { compostagem, } \\
\text { CDR, DA }\end{array}$ & COMENTÁRIOS GERAIS \\
\hline Custo logístico & 3 & 1 & $\begin{array}{l}\text { Número de veículos } 50 \% \text { maior, no } \\
\text { mínimo, para atendimento à mesma rota } \\
\text { na coleta seletiva e de RSU; } \\
\text { Necessidade de unidades de triagem para } \\
\text { envio à destinação final; } \\
\text { Maior número de veículos para envio de } \\
\text { resíduos ao aterro sanitário. }\end{array}$ \\
\hline $\begin{array}{l}\text { Emissão de } \\
\text { GEE's }\end{array}$ & 3 & 1 & $\begin{array}{l}\text { O maior fluxo de veículos gera mais } \\
\text { emissão de gases de efeito estufa. }\end{array}$ \\
\hline $\begin{array}{l}\text { Investimento } \\
\text { tecnológico }\end{array}$ & 1 & 3 & $\begin{array}{c}\text { Alto investimento em equipamentos para } \\
\text { a planta de TMB }\end{array}$ \\
\hline $\begin{array}{c}\text { Investimento } \\
\text { em } \\
\text { conscientização }\end{array}$ & 3 & 1 & $\begin{array}{c}\text { Necessidade de investimento contínuo } \\
\text { para a separação do lixo por parte da } \\
\text { população }\end{array}$ \\
\hline $\begin{array}{l}\text { Volume enviado } \\
\text { ao aterro }\end{array}$ & 3 & 1 & $\begin{array}{l}\text { Maior volume de resíduos enviado ao } \\
\text { aterro, já que somente a Usina do Caju } \\
\text { tem unidades para processamento do lixo. }\end{array}$ \\
\hline \begin{tabular}{c|} 
Custos \\
remediação do \\
aterro pós \\
fechamento \\
\end{tabular} & 2 & 1 & $\begin{array}{c}\text { Com maiores volumes enviados ao aterro, } \\
\text { o tempo de tratamento após sua } \\
\text { conclusão serão maiores. }\end{array}$ \\
\hline $\begin{array}{l}\text { Custo } \\
\text { tratamento de } \\
\text { chorume }\end{array}$ & 3 & 1 & $\begin{array}{l}\text { Com a redução do volume enviado ao } \\
\text { aterro, a produção de chorume cai } \\
\text { proporcionalmente, reduzindo seu custo } \\
\text { de tratamento. }\end{array}$ \\
\hline $\begin{array}{l}\text { Tempo duração } \\
\text { do aterro }\end{array}$ & 1 & 3 & $\begin{array}{l}\text { Com maiores volumes enviados ao aterro, } \\
\text { o tempo de duração deste será maior. De } \\
\text { acordo com as quantidades simuladas } \\
\text { nesta metodologia, o tempo de duração } \\
\text { apresentará acréscimo de } 50 \% \text {. }\end{array}$ \\
\hline $\begin{array}{l}\text { Geração do } \\
\text { biogás }\end{array}$ & 2 & 1 & $\begin{array}{l}\text { Tanto o aterro sanitário quanto a digestão } \\
\text { anaeróbia incluída na planta de TMB } \\
\text { podem gerar o biogás, sendo a planta TMB } \\
\text { em proporções menores. }\end{array}$ \\
\hline $\begin{array}{c}\text { Nível de } \\
\text { conhecimento } \\
\text { exigido para a } \\
\text { operação } \\
\end{array}$ & 2 & 3 & $\begin{array}{l}\text { Os equipamentos do TMB exigem maior } \\
\text { conhecimento técnico. }\end{array}$ \\
\hline
\end{tabular}




\begin{tabular}{|c|c|c|c|}
\hline $\begin{array}{l}\text { Nível de } \\
\text { envolvimento } \\
\text { político }\end{array}$ & 3 & 1 & $\begin{array}{c}\text { Somente no início para o investimento em } \\
\text { equipamentos. }\end{array}$ \\
\hline $\begin{array}{l}\text { Cumprimento } \\
\text { do índice de } \\
\text { reciclagem }\end{array}$ & 3 & 1 & $\begin{array}{c}\text { A unidade de tratamento mecânico pode } \\
\text { aumentar o volume de itens recicláveis a } \\
\text { curto prazo. Uma unidade de lavagem de } \\
\text { materiais na planta de TMB pode gerar } \\
\text { ainda mais itens valorizados para a } \\
\text { reciclagem. }\end{array}$ \\
\hline $\begin{array}{l}\text { Cumprimento } \\
\text { da hierarquia } \\
\text { resíduos }\end{array}$ & 3 & 1 & $\begin{array}{c}\text { A planta de TMB encaminhará os resíduos } \\
\text { de acordo com a hierarquia definida na } \\
\text { PNRS. }\end{array}$ \\
\hline $\begin{array}{l}\text { Cumprimento } \\
\text { da meta para } \\
\text { envolvimento } \\
\text { de catadores }\end{array}$ & 1 & 2 & $\begin{array}{c}\text { Com menor nível de mecanização, a } \\
\text { separação dos itens recicláveis originados } \\
\text { da coleta seletiva exige a participação de } \\
\text { maior número de catadores. }\end{array}$ \\
\hline $\begin{array}{c}\text { Retorno à } \\
\text { rentabilidade do } \\
\text { negócio para os } \\
\text { catadores, } \\
\text { anteriormente } \\
\text { obtida com a } \\
\text { catação } \\
\end{array}$ & 3 & 1 & $\begin{array}{l}\text { O maior volume de itens recicláveis a } \\
\text { comercializar gera maior faturamento. O } \\
\text { TM apresenta maior produtividade na } \\
\text { obtenção de materiais recicláveis. }\end{array}$ \\
\hline TOTAL & 36 & 22 & \\
\hline
\end{tabular}

Tabela 36 - Análise comparativa de cenários na GRSU no município do Rio de Janeiro.

\begin{tabular}{|r|c|} 
Pontuação & Descrição \\
\hline 1 & Adequado/atendimento das metas em curto prazo \\
\hline 2 & Adequado parcialmente/atendimento das metas em médio prazo \\
\hline 3 & Não adequado/atendimento das metas em longo prazo ou sem previsão \\
\hline
\end{tabular}

Tabela 37 - Critérios para avaliação da análise comparativa.

\section{a) Custos Logísticos e emissão de GEE's (fator crítico 01 e 02)}

A implantação de uma unidade TMB apresenta ganhos logísticos que envolvem vários fatores, diretamente ligados à redução do volume de resíduos enviados para o aterro, conforme detalha-se a seguir.

- Redução de veículos envolvidos na coleta do lixo - com a utilização do TMB, os veículos da coleta convencional coletam também os itens recicláveis, reduzindo-se assim o número de veículos exclusivos para a coleta seletiva e consequentemente gastos com combustível e manutenção destes.

Além da redução do número de veículos, a eficiência das rotas é maior, já que resíduos recicláveis são mais leves e ocupam mais espaço.

Pode- se exemplificar que no cenário atual, um veículo utilizado para a coleta de RSU abrange um maior número de residências do que um utilizado para a coleta seletiva. 
- Redução de veículos utilizados na triagem e no envio de resíduos ao aterro - com o tratamento de $50 \%$ do RSU em unidades TMB, o volume enviado ao aterro será reduzido proporcionalmente, gerando menor número de viagens entre Unidade de Triagem/Aterro;

- Redução do número de unidades de triagem - com o tratamento de $50 \%$ do RSU em unidades TMB, o volume enviado ao aterro será reduzido proporcionalmente, com possibilidades de redução do número de unidades de triagem.

Tais fatores também apresentam ganhos ambientais, com a redução de GEE emitidos pelos veículos.

\section{b) Investimento Tecnológico (fator crítico 03)}

Os investimentos para a implantação de uma unidade de TMB no porte necessário para absorver $50 \%$ dos RSU do município são muito altos e de difícil previsão, já que os custos obtidos nesta pesquisa variaram representativamente.

$\mathrm{Na}$ Unidade Valnor, foram investidos 31,10 milhões de Euros para o tratamento de 100.000 ton/ano. O volume anual de resíduos gerados para tratamento na unidade TMB proposta é 17 vezes maior que o apresentado neste Estudo de Caso.

Aplicando diretamente esta proporção ao valor investido, a unidade proposta geraria um investimento previsto de 540 milhões de Euros para sua implantação.

É importante considerar que o investimento declarado pela Valnor na implantação da Unidade foi pouco detalhado no Relatório Anual desta empresa, sem informações específicas para os equipamentos e itens estruturais envolvidos no investimento.

Além disso, o custo envolvido para a implantação de plantas estruturais normalmente apresenta altos custos iniciais de implantação, reduzindo-se o custo unitário de acordo com o aumento da escala. Desta forma, é possível concluir que o investimento envolvido na unidade proposta seria menor que os 540 Euros apresentados, porém não é possível calcular o valor exato com as informações levantadas.

Para fins comparativos, foram investidos 356 milhões de reais CTR Santa Rosa, de acordo com informações da Ciclus Ambiental, empresa responsável por este aterro sanitário.

A outra opção para cálculo aproximado do investimento envolvido pode ser realizada de acordo com o orçamento enviado a partir da empresa Maqbrit, detalhado conforme Apêndice 6.5. A empresa, de capital e 
tecnologia brasileira, foi contratada pela Prefeitura de Jundiaí para a instalação de uma unidade de TMB para esta localidade. O projeto da Prefeitura de Jundiaí ainda está em andamento, sem data prevista para inauguração.

O orçamento previsto pela Maqbrit prevê o investimento de $\mathrm{R} \$ 1.635 .000,00$ para o tratamento de 300ton/dia. Aplicando a proporção para a quantidade a ser tratada na unidade TMB proposta (16 vezes maior), chega-se a um investimento de 26 milhões de reais, este muito abaixo das médias atuais.

A unidade de tratamento mecânico da Ecourbis apresentou investimento total de 33 milhões de reais para o processamento de 250 ton/dia de resíduos originados somente da coleta seletiva, unidade que necessita de menor investimento. Aplicando-se a proporção dos volumes gerados, chegaríamos a um total de 633 milhões de reais.

Para esta comparação, também seria importante o detalhamento do investimento da Ecourbis, informações não obtidas nas pesquisas de campo e entrevistas realizadas.

Como a Usina do Caju apresenta boa estrutura e área disponível, o estudo propõe a utilização e adaptação desta unidade para a aplicação do TMB. Desta forma, os custos com instalações prediais, construção do fosso e área para compostagem e CDR seriam reduzidos.

De acordo com os fatores abordados acima, o estudo não poderá gerar um valor específico comparativo, porém é possível concluir-se que o investimento para a utilização desta unidade é maior do que os investimentos previstos para a continuidade das ações previstas no PMGIRS/RJ, mesmo que ainda não prevejam o tempo para 0 cumprimento da hierarquia citada na PNRS (2010).

c) Investimento em campanhas de conscientização (fator crítico 04)

Um dos fatores que dificulta o sucesso da coleta seletiva é a conscientização da população para a separação e tratamento do lixo. Conforme apresentado no Capítulo 2, a separação do lixo por parte da população depende de mudança cultural, necessitando de investimentos representativos e frequentes em conscientização, com retorno de longo prazo.

De acordo com informações também abordadas no Capítulo 2, os índices que envolvem a coleta seletiva na Alemanha apresentaram resultados positivos após 10 anos de investimento maciço em conscientização, acompanhados de um bom plano de gestão de resíduos, que foram cumpridos pelos gestores públicos. 
O PMGIRS/RJ está bem definido, porém depende de investimento e acompanhamento direto dos gestores públicos, fato que não tem ocorrido desde seu lançamento, conforme depoimentos obtidos nas pesquisas de campo.

Outro fato que demostra o não cumprimento dos Gestores Públicos é o pedido de postergação das metas, documentado pelo Decreto no 8.211, publicado em 21 de Março de 2014, alterando a data limite para 31 de dezembro de 2015 sobre a existência de um plano de saneamento básico como condição de acesso aos recursos da União.

Desta forma, é possível concluir que a necessidade de investimento para a conscientização da população brasileira no cenário atual é muito maior do que a utilizada no cenário proposto.

d) Volume enviado ao aterro e custos operacionais envolvidos (fatores 05, 06, 07, 08).

O cenário proposto analisa o tratamento de $50 \%$ do volume na unidade $\mathrm{TMB}$, reduzindo o volume de resíduos enviados para o aterro na mesma proporção, dobrando seu tempo de vida útil, atualmente estimado em 17 anos.

Com a utilização de tratamento biológico dos resíduos como a decomposição anaeróbia e compostagem, o volume de chorume também será reduzido proporcionalmente, apresentando representativos ganhos de custo em seu tratamento a longo prazo.

e) Geração do biogás (fator crítico 09)

Dentre as diversas vantagens, é importante avaliar-se a redução do volume de biogás gerado no aterro e suas consequências ambientais e econômicas quando da utilização do TMB para os resíduos sólidos urbanos.

Como o volume enviado ao aterro será reduzido à metade, a geração do biogás a partir desta atividade apresentará redução proporcional, porém a unidade TMB também pode apresentar ganhos na geração de energia, tanto a partir do biogás na digestão anaeróbia, como no CDR.

Aplicando as mesmas proporções resultantes da Unidade Valnor (31\% de CDR e $45 \%$ de rejeitos, a utilizar-se na digestão anaeróbia) e a energia gerada a partir destes processos conforme abordado no Capítulo 2, o cenário proposto $(50 \% \mathrm{TMB}, 50 \%$ destinação atual) poderá gerar 1.333.231 KWh, $60 \%$ do gerado atualmente. 


\begin{tabular}{|l|l|l|l|}
\hline \multirow{2}{*}{ ATIVIDADE } & \multicolumn{2}{c|}{ UNIDADE TMB } & \multirow{2}{*}{ ENVIO ATERRO } \\
\cline { 2 - 3 } & \multicolumn{2}{|c|}{ CDR } & \multicolumn{1}{c|}{ DA } \\
\hline $\begin{array}{l}\text { Geração de } \\
\text { resíduos (ton/dia) }\end{array}$ & \multicolumn{2}{|c|}{4.833} & \\
\hline \% resíduos & $31 \%$ & $45 \%$ & $100 \%$ \\
\hline Volume (ton/dia) & 1.498 & 2.175 & 4.833 \\
\hline Energia (KWh) & 2.150 & 198.999 & 1.132 .082 \\
\hline
\end{tabular}

Tabela 38 - Comparativo de geração de energia entre a Unidade TMB e envio ao Aterro Sanitário.

Para a conclusão de uma análise de viabilidade econômica, faz-se importante a obtenção de dados mais detalhados a respeito das receitas e custos envolvidos em cada cenário, porém não foi possível obter tais valores, tanto no cenário atual como no proposto.

A análise da adequação do cenário atual para o proposto quanto à adequação às políticas ambientais é totalmente viável, pois envolve a hierarquia de destinação e redução de volume de resíduos enviado para aterro.

Sendo assim, o cenário proposto novamente apresenta mais vantagens que $o$ atual neste quesito.

f) Nível de conhecimento técnico exigido para a operação (fator crítico 10)

Conforme abordado em capítulos anteriores, a forma como a responsabilidade sobre a gestão de resíduos foi direcionada às cooperativas de catadores não tem apresentado resultados satisfatórios, dada a falta de conhecimento técnico dos envolvidos e baixo envolvimento político no processo.

Ao incluir equipamentos de operação e manutenção complexa, como detectores que utilizam infra vermelho e informações totalmente computadorizadas, os operadores desta planta necessitarão de maior treinamento e especialização do que o necessário para operação no cenário atual, tanto no nível dos cooperados como para os profissionais contratados pela empresa controladora de resíduos, no caso a Comlurb.

Desta forma, o cenário atual apresenta-se mais favorável no que diz respeito a este quesito.

g) Nível de envolvimento político (fator crítico 11)

Um dos diferenciais de maior representatividade entre o cenário atual e o proposto é o aproveitamento dos resíduos recicláveis sem os custos e investimentos envolvidos na coleta seletiva, que requer envolvimento e participação política contínua. 
No tratamento a partir do $\mathrm{TM}$, as grandes cifras ficam envolvidas no primeiro momento, durante a construção da planta, podendo ser realizado em sua totalidade dentro de um mandato político. O restante a ser gasto é contabilizado como custo operacional, rubrica que exige menor burocracia para sua liberação, já que é bem menor e envolve necessidades básicas da população.

Tal ponto é extremamente importante e representativo num cenário brasileiro, pois garante o sucesso da proposta em longo prazo, sem dificuldades políticas para a sua manutenção.

Os resultados de curto prazo também são extremamente importantes para decisões políticas, pois interferem diretamente na reputação do gestor público, avaliado pela população e poderes privados, gerando votos para a continuidade do mandato no processo eleitoral seguinte e consequente continuidade do processo.

Em contrapartida, a reciclagem dependente da coleta seletiva exigirá investimentos contínuos em longo prazo, que poderão ser cortados ou drasticamente reduzidos numa mudança de mandato político.

\section{h) Índice de reciclagem e hierarquia de resíduos (fatores 12 e 13)}

Se compararmos os resultados da coleta seletiva com os resultados que seriam obtidos com esta unidade de TMB para somente $50 \%$ dos resíduos gerados, o índice de reciclados neste novo modelo atingiria a meta estabelecida no PMGIRS/RJ no $1^{\circ}$ ano de funcionamento, conforme detalhado nas Tabelas 39 e 40 a seguir.

RESULTADOS OBTIDOS COM A COLETA SELETIVA

\begin{tabular}{|c|c|c|c|c|c|c|c|c|}
\hline $\begin{array}{c}\text { GERAÇÃO } \\
\text { (ton/dia) }\end{array}$ & $\begin{array}{c}\% \\
\text { RECICLA } \\
\text { VEL }\end{array}$ & $\begin{array}{c}\text { VELCICLAVEL } \\
\text { (ton/dia) }\end{array}$ & $\begin{array}{c}\% \\
\text { COLETA } \\
\text { DO } \\
\text { Coleta } \\
\text { Seletiva }\end{array}$ & $\begin{array}{c}\text { VOLUME } \\
\text { COLETADO } \\
\text { Col. } \\
\text { Seletiva } \\
\text { (ton/dia) }\end{array}$ & $\begin{array}{c}\% \\
\text { RECICL } \\
\text { ADO }\end{array}$ & $\begin{array}{c}\text { VOLUME } \\
\text { RECICLAD } \\
\text { O } \\
\text { (ton/dia) }\end{array}$ & $\begin{array}{c}\% \text { RECL } \\
\text { SOBRE } \\
\text { TOTAL }\end{array}$ & ANO \\
\hline 9.666 & $41 \%$ & 3.963 & $1,40 \%$ & 55 & $70 \%$ & 39 & $1,0 \%$ & 2012 \\
\hline 9.666 & $41 \%$ & 3.963 & $1,40 \%$ & 55 & $70 \%$ & 39 & $1,0 \%$ & 2013 \\
\hline 9.666 & $41 \%$ & 3.963 & $5 \%$ & 198 & $70 \%$ & 139 & $3,5 \%$ & 2014 \\
\hline 9.666 & $41 \%$ & 3.963 & $25 \%$ & 991 & $70 \%$ & 694 & $17,5 \%$ & 2016 \\
\hline
\end{tabular}

Tabela 39 - Coleta seletiva: resultados do município do Rio de Janeiro em 2012 e projeção para próximos anos.

Memória de cálculo para a tabela 39:

- Geração de resíduos (ton/dia) - 9.666 ton/dia;

- Percentual reciclável-41\% - Fonte: PNRS;

- Volume reciclável (ton/dia): 0,41*9.666 = 3.963;

- Percentual coleta seletiva em 2012 (ton/dia): 0,014*3.963 = 55;

- Percentual reciclado, a partir da coleta seletiva em 2012 (ton/dia): $0,70 * 55=39$; 
- Percentual reciclado sobre o total reciclável em 2012: 39/3.963 = $1 \%$

O PMGIRS/RJ estabelece a meta para a coleta de itens recicláveis, sem quantificar o índice de reciclagem. As metas definidas são de $5 \%$ do volume reciclável até 2013 e $25 \%$ até 2016, sendo este volume comparado com o volume de itens recicláveis, gerados no município.

Desta forma, considerando o índice gravimétrico da cidade (41\% para materiais recicláveis) e uma perda de $30 \%$ nos itens coletados, a meta de $5 \%$ de materiais coletados pode ser interpretada como $3,5 \%$ encaminhado à reciclagem, conforme demonstra a Tabela 39.

O mesmo cálculo pode ser aplicado à meta de $25 \%$ de materiais coletados, que de acordo com as proporções utilizadas, resultaria em $17,5 \%$ encaminhado à reciclagem, se comparado ao volume total gerado.

Conforme citado, os itens percentuais de coleta obtidos em 2012 e 2013 não atenderam às metas do Plano. De acordo com as pesquisas de campo, o índice de coleta se mantiveram os mesmos nos anos posteriores, por isso encontram-se na cor vermelha na Tabela 39, demonstrando resultado em desacordo com a Política.

Para os anos seguintes (2014 e 2016), considerou-se a meta do Plano para cálculo dos índices.

Analisando os resultados da situação proposta, com tratamento na planta de TMB em $50 \%$ do volume gerado no município e considerando a mesma perda do volume separado para reciclagem (30\%), o mesmo índice de $17,5 \%$ atingido na coleta seletiva previsto para 2016 seria atingido no $1^{\circ}$ ano de implantação, conforme demonstra a Tabela 40 a seguir.

\section{RESULTADOS OBTIDOS NA SITUAÇÃO PROPOSTA}

1. PLANTA TMB

\begin{tabular}{|c|c|c|c|c|c|c|c|c|}
\hline $\begin{array}{c}\text { GERAÇÃO } \\
\text { (ton/dia) }\end{array}$ & $\begin{array}{c}\% \\
\text { RECICL } \\
\text { AVEL }\end{array}$ & $\begin{array}{c}\text { VOLUME } \\
\text { RECICLAVEL } \\
\text { (ton/dia) }\end{array}$ & $\begin{array}{c}\% \\
\text { SEPA } \\
\text { RADO } \\
\text { TMB }\end{array}$ & $\begin{array}{c}\text { VOL. } \\
\text { TMB } \\
\text { (ton/dia) }\end{array}$ & $\begin{array}{c}\% \\
\text { RECIC } \\
\text { LADO }\end{array}$ & $\begin{array}{c}\text { VOL. } \\
\text { RECICL } \\
\text { ADO } \\
\text { (ton/di } \\
\text { a) }\end{array}$ & $\begin{array}{c}\% \text { RECL } \\
\text { SOBRE } \\
\text { TOTAL }\end{array}$ & ANO \\
\hline 4.833 & $41 \%$ & 1.982 & $25 \%$ & 495 & $70 \%$ & 347 & $17,5 \%$ & 10 ano \\
\hline 4.833 & $41 \%$ & 1.982 & $25 \%$ & 495 & $70 \%$ & 347 & $17,5 \%$ & 20 ano \\
\hline 4.833 & $41 \%$ & 1.982 & $25 \%$ & 495 & $70 \%$ & 347 & $17,5 \%$ & 30 ano \\
\hline 4.833 & $41 \%$ & 1.982 & $25 \%$ & 495 & $70 \%$ & 347 & $17,5 \%$ & 40 ano \\
\hline
\end{tabular}


2. COLETA SELETIVA

\begin{tabular}{|r|r|l|r|r|r|r|r|r|}
\hline $\begin{array}{r}\text { GERAÇÃO } \\
\text { (ton/dia) }\end{array}$ & $\begin{array}{c}\% \\
\text { RECICL } \\
\text { AVEL }\end{array}$ & $\begin{array}{c}\text { VOLUME } \\
\text { RECICLAVEL } \\
\text { (ton/dia) }\end{array}$ & $\begin{array}{c}\% \\
\text { COLE } \\
\text { TADO }\end{array}$ & $\begin{array}{c}\text { VOL. } \\
\text { COLETAD } \\
\text { (ton/dia) }\end{array}$ & $\begin{array}{c}\% \\
\text { RECIC } \\
\text { LADO }\end{array}$ & $\begin{array}{c}\text { VOL. } \\
\text { RECICL } \\
\text { ADO }\end{array}$ & $\begin{array}{c}\% \text { RECL } \\
\text { SOBRE } \\
\text { TOTAL }\end{array}$ & ANO \\
\hline 4.833 & $41 \%$ & 1.982 & $1,4 \%$ & 28 & $70 \%$ & 19 & $1,0 \%$ & 10 ano \\
\hline 4.833 & $41 \%$ & 1.982 & $1,4 \%$ & 28 & $70 \%$ & 19 & $1,0 \%$ & 2 ㅇano \\
\hline 4.833 & $41 \%$ & 1.982 & $5,0 \%$ & 99 & $70 \%$ & 69 & $3,5 \%$ & 3ㅇ ano \\
\hline 4.833 & $41 \%$ & 1.982 & $25,0 \%$ & 495 & $70 \%$ & 347 & $17,5 \%$ & 4ㅇ ano \\
\hline
\end{tabular}

3. TOTAL

\begin{tabular}{|c|c|c|c|c|c|c|c|c|}
\hline $\begin{array}{c}\text { GERAÇÃO } \\
\text { (ton/dia) }\end{array}$ & $\begin{array}{c}\% \\
\text { RECICL } \\
\text { AVEL }\end{array}$ & $\begin{array}{c}\text { VECICLAVEL } \\
\text { (ton/dia) }\end{array}$ & $\begin{array}{c}\% \\
\text { SEPA } \\
\text { RADO } \\
\text { TOTA } \\
\text { L }\end{array}$ & $\begin{array}{c}\text { VOLUME } \\
\text { SEPARA } \\
\text { DO } \\
\text { TOTAL } \\
\text { (ton/dia) }\end{array}$ & $\begin{array}{c}\text { \% } \\
\text { RECIC } \\
\text { LADO }\end{array}$ & $\begin{array}{c}\text { EOLCICL } \\
\text { ADO } \\
\text { (ton/di } \\
\text { a) }\end{array}$ & $\begin{array}{c}\text { \% RECL } \\
\text { SOBRE } \\
\text { TOTAL }\end{array}$ & ANO \\
\hline 9.666 & $41 \%$ & 3.963 & $13 \%$ & 523 & $70 \%$ & 366 & $9,2 \%$ & 10 ano \\
\hline 9.666 & $41 \%$ & 3.963 & $13 \%$ & 523 & $70 \%$ & 366 & $9,2 \%$ & 20 ano \\
\hline 9.666 & $41 \%$ & 3.963 & $15 \%$ & 594 & $70 \%$ & 416 & $10,5 \%$ & 3o ano \\
\hline 9.666 & $41 \%$ & 3.963 & $25 \%$ & 991 & $70 \%$ & 694 & $17,5 \%$ & 40 ano \\
\hline
\end{tabular}

Tabela 40- Resultados obtidos na separação de itens recicláveis com o TMB.

Memória de cálculo para a tabela 40 - PLANTA TMB:

- Geração de resíduos (ton/dia) - 4.833 (50\% do total gerado diariamente: 9.666);

- Percentual reciclável-41\% - Fonte: PNRS;

- Volume reciclável (ton/dia): 0,41*4.833 = 1.982;

- Percentual separado no 1ำ ano (ton/dia): 0,25*1.982 = 495;

- Percentual reciclado (ton/dia): 0,70*495 = 347;

- Percentual reciclado sobre o total reciclável no $1^{\circ}$ ano: 347/1.982 = $17,5 \%$

Memória de cálculo para a tabela 40 - COLETA SELETIVA:

- Geração de resíduos (ton/dia) - 4.833 (50\% do total gerado diariamente: 9.666);

- Percentual reciclável-41\% - Fonte: PNRS;

- Volume reciclável (ton/dia): 0,41*4.833 = 3.963;

- Percentual separado no 1ำ ano (\%):0,014*1.982=28;

- Percentual reciclado (ton/dia): 0,70*28 = 19;

- Percentual reciclado sobre o total reciclável no $1^{\circ}$ ano: 19/1.982 = $1 \%$ 
Memória de cálculo para a tabela 40 - TOTAL:

- Geração de resíduos (ton/dia) -9.666;

- Percentual reciclável - 41\% - Fonte: PNRS;

- Volume reciclável (ton/dia): $0,4{ }^{*} 9.666=1.982$;

- Volume total separado no $1^{\circ}$ ano (ton/dia): $495+28=523$;

- Percentual separado no 10 ano (\%): 523/3.963 = 13\%;

- Volume reciclado (ton/dia): $347+19=366$;

- Percentual reciclado sobre o total reciclável no $1^{\circ}$ ano: $366 / 3.963=$ $9,2 \%$

É importante lembrar que as metas definidas do PMGIRS/RJ consideravam a instalação das 6 unidades de separação no $1^{\circ}$ ano de sua publicação. De acordo com entrevistas realizadas na Diretoria de Serviços Especiais e Ambientais da Comlurb conforme detalha o Apêndice 6.5, até o momento somente uma unidade se encontra em funcionamento.

Desta forma, provavelmente a meta de coleta de 5\% para 2014 não será atingida, bem como a de $25 \%$ prevista para 2016.

Apresentam-se então como mais um fator desfavorável ao cenário atual no que diz respeito aos fatores críticos 11 (onze) e 12 (doze).

i) Cumprimento de meta para o envolvimento de catadores (fator crítico 14)

No que envolve os catadores, tanto a PNRS como os desdobramentos estaduais e municipais colocam a quantidade de catadores envolvidos como meta a seguir. Por ser um processo mecanizado, o TMB pode apresentar a necessidade de envolvimento de um menor número de pessoas, se comparado ao mesmo volume de resíduos num processo de separação manual.

Stephanie (2011) em seu estudo sobre a realidade das 61 (sessenta e um) Unidades de MBT da Alemanha, coloca que o número que pessoas envolvidas nestas unidades de tratamento de lixo são subestimadas e portanto apresentam-se como um dos problemas encontrados durante a operação nas plantas. Desta forma, considerou-se para a avaliação de cenários um conceito mediano para a situação proposta neste fator crítico.

Embora o cenário atual apresente-se mais favorável à este quesito, atualmente os resultados na coleta seletiva têm gerado baixo envolvimento de catadores.

Existem somente 42 operadores na Unidade de Irajá e 120 na Usina do Caju, muito abaixo dos 1.500 previstos no PMGIRS/RJ, embora existam cooperativas envolvidas em outros processos no município, que não a coleta seletiva.

Em contrapartida, realizando a mesma proporção de catadores utilizada na Central Ecourbis, que será abordada no Estudo de Caso 4.2, para cálculo da quantidade de catadores previstos para operação, o cenário 
proposto atuaria com no mínimo 558 catadores, um número maior do que os contratados atualmente.

Para este cálculo, utilizou-se a proporção de operadores na Central Ecourbis conforme será detalhado no Apêndice 6.3 e não a proporção da Unidade Valnor, buscando a melhor aproximação ao cenário brasileiro.

A quantidade de 396 catadores para a planta TMB foi obtida através da proporção de resíduos trabalhada na unidade proposta (1.982 ton dia $50 \%$ d total de resíduos recicláveis gerados no município, conforme cálculo da Tabela 40), versus a quantidade de resíduos tratada na Ecourbis (250 ton/dia). Tal proporção gera o fator de 7,928.

Multiplicando o número de catadores da unidade Ecourbis por este fator, obtém-se o número de 396 catadores para a Planta TMB proposta.

Para os $50 \%$ restantes de RSU mantidos com o mesmo tratamento conforme o cenário atual, repetiu-se o número de catadores envolvidos.

Faz- se importante pontuar que a Central Ecourbis trata somente resíduos originados da coleta seletiva, necessitando de menor intervenção manual do que uma unidade de tratamento mecânico para RSU. Desta forma, o número de catadores envolvidos tenderá a ser maior que o calculado.

\begin{tabular}{|c|c|c|c|c|}
\hline Indicadores & ECOURBIS & PLANTA TMB & $\begin{array}{c}\text { COLETA } \\
\text { SELETIVA }\end{array}$ & TOTAL \\
\hline $\begin{array}{c}\text { QUANTIDADE } \\
\text { CATADORES } \\
\text { (pessoas) }\end{array}$ & $\mathbf{5 0}$ & 396 & 162 & $\mathbf{5 5 8}$ \\
\hline $\begin{array}{c}\text { VOLUME } \\
\text { PROCESSADO } \\
\text { (ton/dia) }\end{array}$ & $\mathbf{2 5 0}$ & 1.982 & 1.982 & $\mathbf{3 . 9 6 4}$ \\
\hline
\end{tabular}

Tabela 41 - Quantidade de catadores envolvidos - Caso Ecourbis x Cenário Proposto.

j) Rentabilidade do negócio para estes atores do processo (fator crítico 15)

A respeito da rentabilidade gerada aos catadores, considera-se o cenário proposto mais favorável.

Atualmente, os resultados da coleta seletiva bem como o baixo volume de resíduos secos coletados a partir de órgãos públicos e privados não apresentam resultados satisfatórios conforme o previsto no PMGIRS/RJ, devido aos problemas na coleta seletiva e a falta de conhecimento técnico dos catadores, conforme apresentados no Capítulo 3.

No cenário proposto, o nível de remuneração apresentará resultados imediatos se comparados ao cenário atual, devido ao crescimento do volume aproveitado, bem como maior valor agregado às embalagens, com a utilização da Unidade de Lavagem dentro da planta de TMB. 


\subsection{Estudo de Caso - Portugal - Unidade Valnor}

Portugal é um país da União Européia (UE), com 10.487.289 habitantes, $91.985 \mathrm{~km}^{2}$, PIB per capita de 16.686,3 Euros (INE-BP, INE, PORDATA, 2011), ocupando a $41^{\text {a }}$ posição no IDH, de uma lista de 187 países (PNUD, 2012).

O país gera gerou 4,5 millhões de toneladas de RSU em 2005 ou $1,24 \mathrm{~kg}$ por habitante (PERSU II, 2006). Deste volume, 33,84\% são de matéria orgânica, $44,26 \%$ de materiais recicláveis e $21,9 \%$ de outros materiais.

Para controlar a hierarquia do consumo e destino de resíduos de acordo com as normas da UE, Portugal apresenta um Plano Estratégico para Resíduos Sólidos Urbanos (PERSU II), com metas definidas até 2016.

Para o controle destes resíduos, existem 23 sistemas de gestão de resíduos, no qual está incluída a Valnor AS, que responde por um destes sistemas e atua sob contrato de concessão, com validade até 2036.
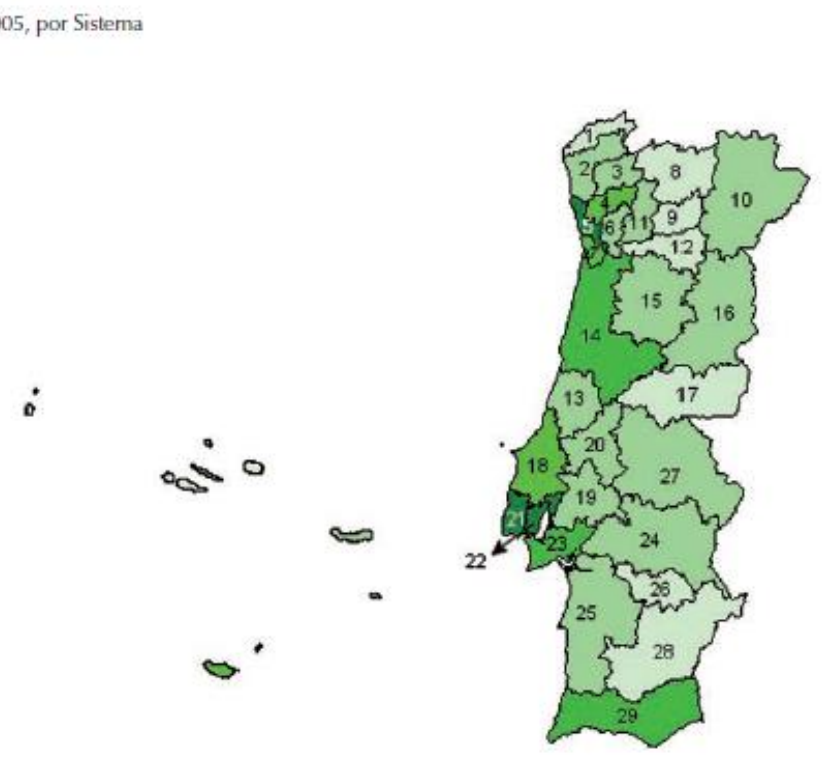

1. VALORMINHO

2. RESULIMA

3. BRAVAL

4. Amave

5. Lipor

Valsousa

7. SULDOURO

8. RESAT

9. Vale do Douro Norte

10. Resíduos do Nordeste

11. REBAT

12. RESIDOURO

13. VALORUS

13. VALORIS

15. Planalto Beiräo

16. AGUAS ZFZERE E COA

17. Raia - Pinhal

18. RESIOESTE

19. Resiurb

20. Resitejo

21. Amtres

ALORSUL

23. AMARSUL

24. GESAMB

25. Ambilital

26. Amcal

27. VALNOR

28. Resialentejo

29. ALGAR

Figura 55 - Produção total de RSU por sistema - Portugal.

Fonte: PERSU II, 2006.

A Valnor é uma empresa de capital misto, sendo $49 \%$ do capital de responsabilidade dos municípios atendidos pelo serviço e $51 \%$ de posse do Grupo EGF, empresa privada responsável pela gestão integrada de resíduos sólidos urbanos, através de 11 Sistemas Multimunicipais de Tratamento e Valorização de Resíduos Sólidos Urbanos que, no conjunto, envolvem 174 municípios, correspondentes a mais de $60 \%$ da população portuguesa.

A empresa é responsável por um Sistema Multimunicipal de triagem, coleta seletiva, valorização e tratamento de resíduos sólidos urbanos, atendendo a 25 municípios, localizados numa área total de $11.800 \mathrm{~km}^{2}$. 


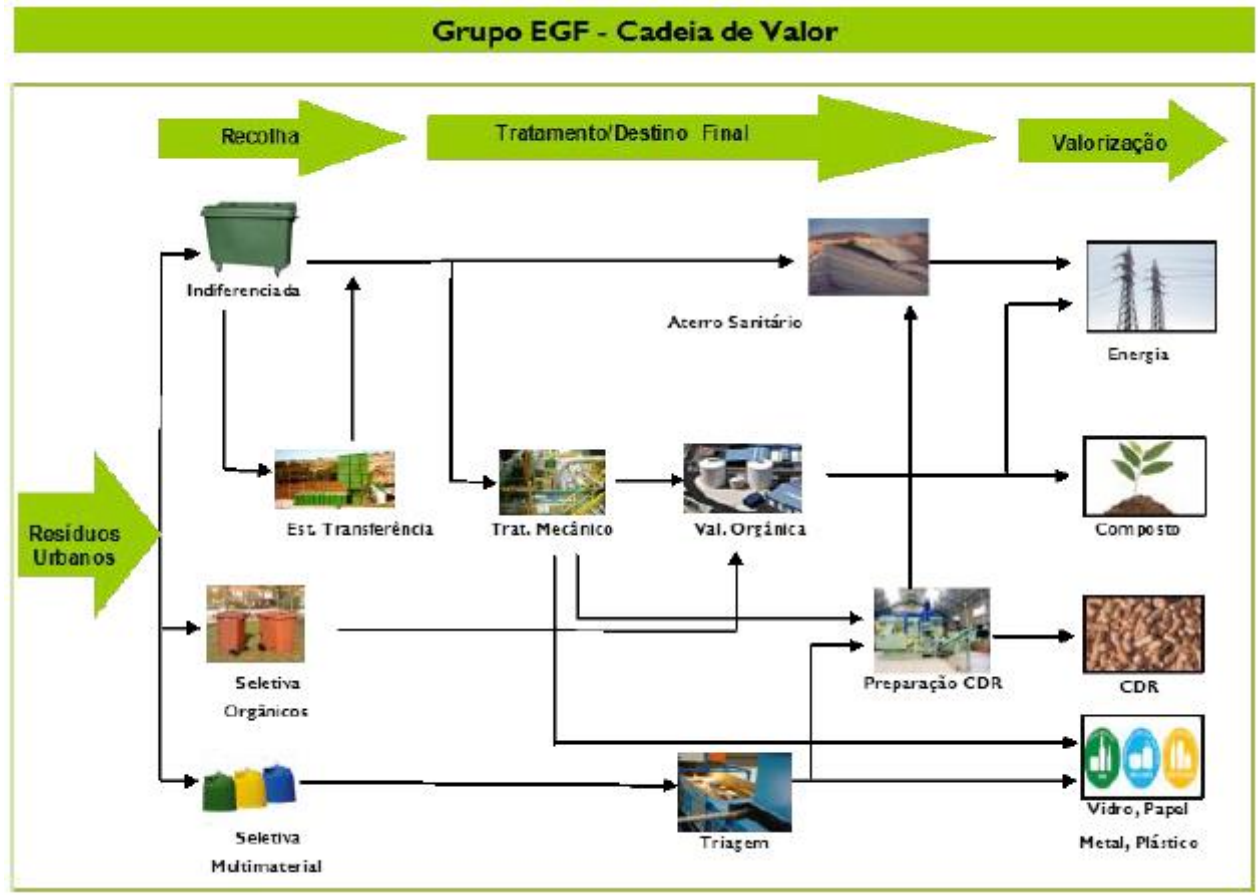

Figura 56 - Fluxo do processo de tratamento de resíduos Valnor.

Fonte: PERSU II, 2006.

A análise deste caso faz-se interessante pela utilização do tratamento mecânico de RSU em concomitância com a coleta seletiva, utilização do resíduo biodegradável tanto em compostagem como em decomposição anaeróbica, gerando também o biogás. Também faz-se interessante por ser um exemplo de iniciativas intermunicipais, conforme a PNRS brasileira prevê.

Iniciando suas atividades em 2001, com a coleta seletiva, foi investido aproximadamente 65 milhões de Euros até 2013. O quadro abaixo detalha os principais investimentos envolvendo a gestão de RSU, totalizando aproximadamente 48 milhões de Euros em 9 anos.

\begin{tabular}{|c|c|c|}
\hline PERIODO & $\begin{array}{c}\text { VALOR } \\
\text { (Milhöes } € \text { ) }\end{array}$ & Unidade Produtiva \\
\hline 2001 & 8 & $\begin{array}{c}\text { Fechamento de 22 lixões, Início coleta seletiva com } \\
400 \text { ecopontos, 1 estação de Triagem e 4 de } \\
\text { transferência, aquisção de veículos. }\end{array}$ \\
\hline 2004 & 8,5 & $\begin{array}{c}\text { Coleta seletiva porta a porta e Central de } \\
\text { Compostagem }\end{array}$ \\
\hline 2008 & 18 & Unidade TMB \\
\hline 2013 & 1,3 & Unidade de Lavagem de Embalagens \\
\hline 2013 & 11,8 & Unidade de Digestão Anaeróbia \\
\hline
\end{tabular}

Tabela 42 - Resumo de investimentos Valnor.

Relatório Anual Valnor, 2013. 
O sistema abrange 25 municípios, servindo a uma população de 271.821 habitantes, coletando 101.663 toneladas de RSU e 8.569 toneladas de materiais na coleta seletiva em 2013.

A atividade é considerada rentável, de acordo com o relatório anual, emitido pela Valnor. Em 2013, o negócio gerou rentabilidade de 4,85\% (resultado líquido/capital próprio) aos acionistas. As principais receitas da Valnor foram obtidas através da comercialização de recicláveis $(68 \%$ da receita) e cobrança de tarifas municipais. $O$ contrato de concessão prevê a cobrança de 31,16 €/ton aos beneficiados por este sistema (VALNOR, 2013).

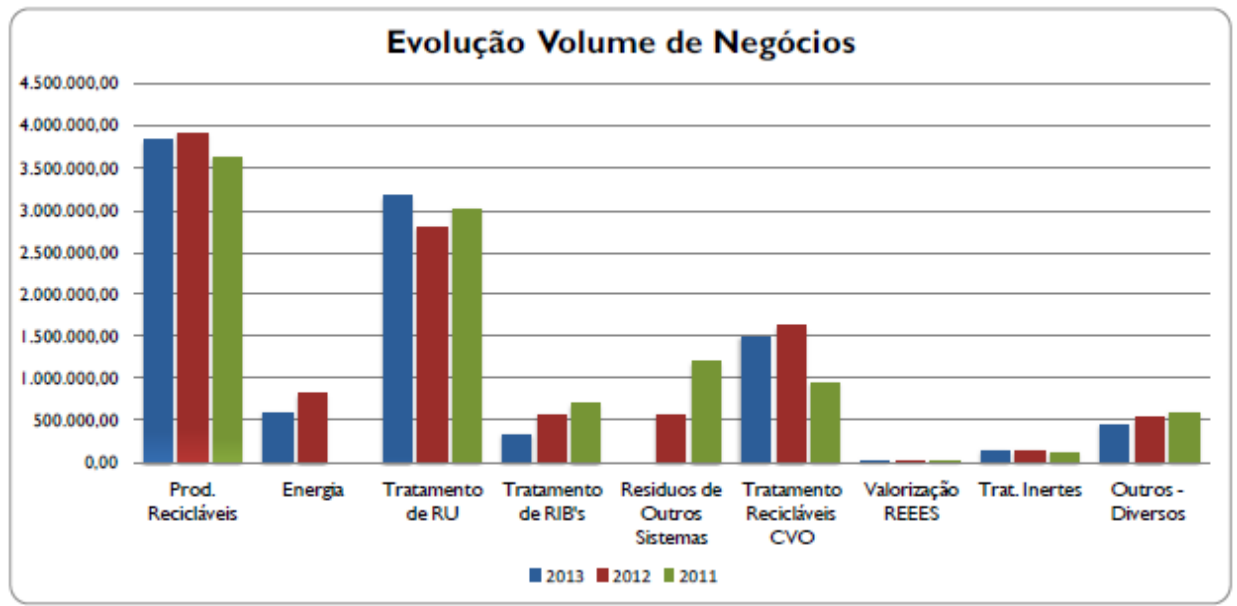

Figura 57 - Evolução do Volume de Negócios Valnor - 2011 a 2013. Fonte: Relatório Anual Valnor, 2013.

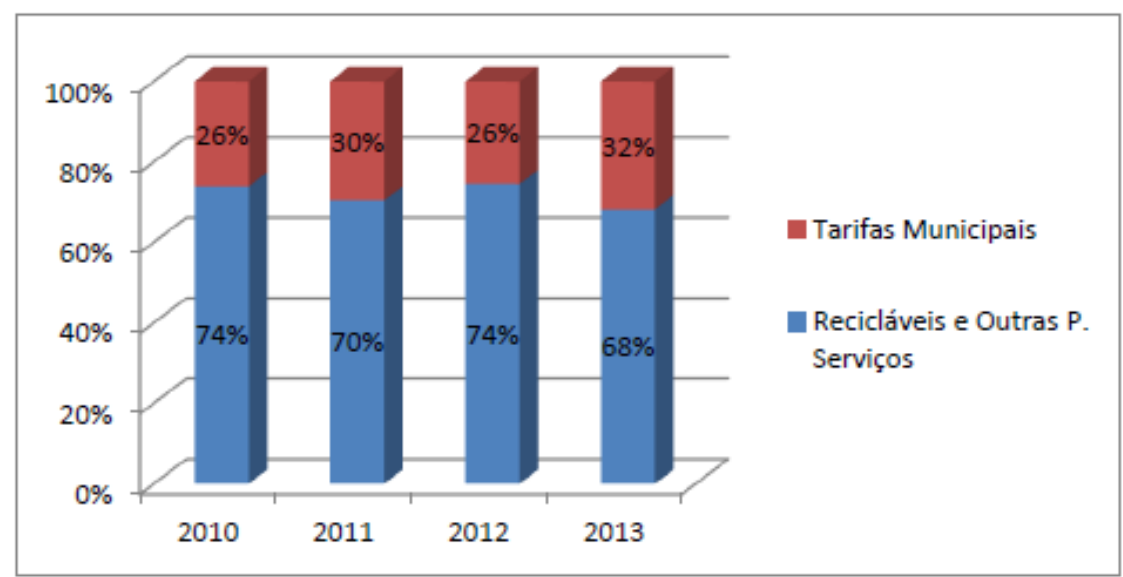

Figura 58 - Evolutivo de participação nas receitas do negócio - 2010 a 2013. Fonte: Relatório Anual Valnor, 2013.

\subsubsection{O processo}

No que envolve o tratamento de RSU, o Sistema Valnor abrange um aterro sanitário, 16 ecocentros, 7 estações de transferência de RSU, uma central de valorização orgânica uma central de triagem de embalagens, um centro de triagem de papel, uma instalação de pré-triagem, uma 
unidade de digestão anaeróbia, uma para preparação de CDR e uma para a produção de biodiesel.

Há também 2 aterros desativados, um em 2011 com estrutura para captação de biodiesel e outro desativado em 2012. A figura abaixo demonstra a infraestrutura distribuída pelas localidades.

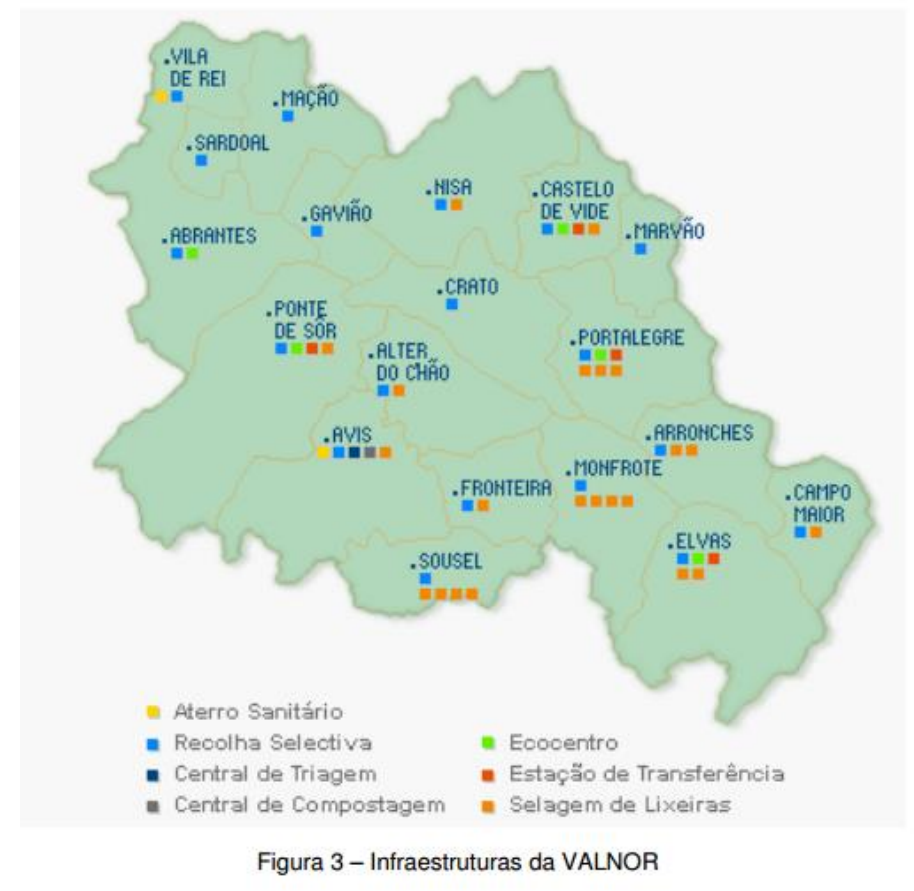

Figura 59 - Mapa Demonstrativo - Infraestruturas da Valnor. Fonte: Relatório Anual Valnor, 2013.

Foi inaugurada em 2014 uma unidade de lavagem de embalagens separadas no tratamento mecânico, visando a melhoria de sua valorização e maior redução de resíduos enviados ao aterro sanitário.

De acordo com Teixeira (2009), a unidade de TMB conta com 14 fases do processo, conforme a Figura 60.

Apos o TM, segue-se o TB, composto por cinco fases distintas: a mistura, pré-compostagem (decomposição da matéria orgânica pela ação de microrganismos, provocada pelo controle de temperatura e oxigênio, adição de água e ventilação forçada), pós-compostagem (os resíduos orgânicos são empilhados e o material é misturado a intervalos regulares, por 12 semanas), afinação e ensacamento.

Em 2013, 11,8 milhões de Euros para a instalação de uma Unidade Digestão Anaeróbia e outra para o processamento do CDR. Com isto, a Unidade de DA terá capacidade para processar 20.000ton/ano, gerando 2.750GW no mesmo período. O processamento de CDR pode chegar a processar 25.000 toneladas de resíduos por ano. 


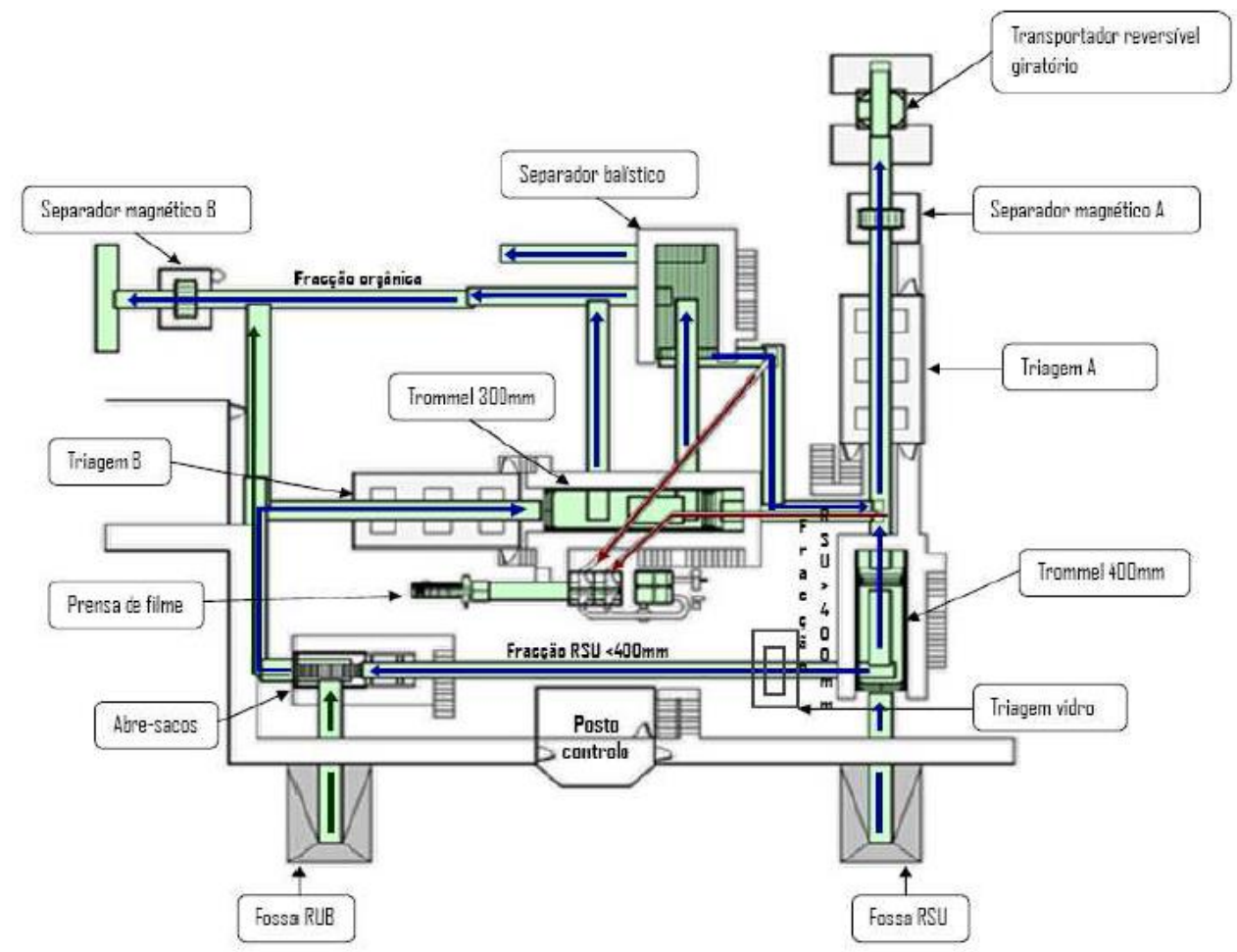

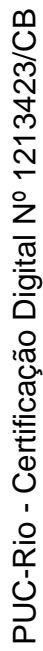

Figura 60 - Figura esquemática - Etapas do processo Valnor.

Fonte: Teixeira, 2009.
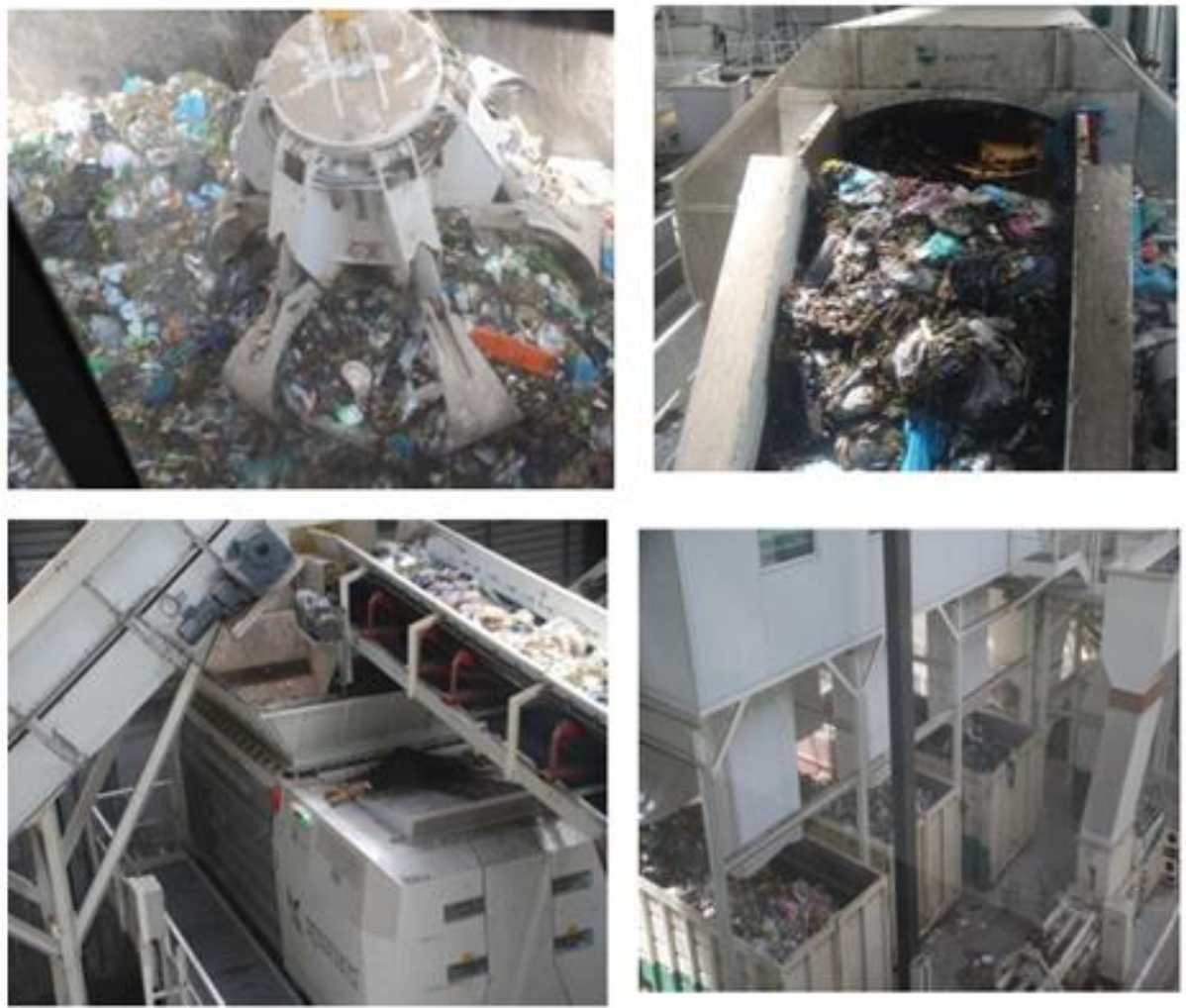

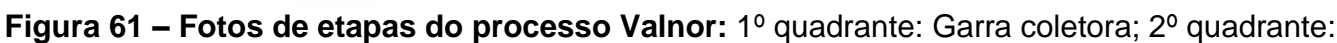
trommel; $3^{\circ}$ quadrante: esteira; $4^{\circ}$ quadrante: separação por itens em containers, a partir de cada fase do processo.

Fonte: Teixeira, 2009. 
A coleta seletiva é realizada tanto em veículos especiais porta a porta, quanto a partir de 900 ecopontos, com capacidade de $2,5 \mathrm{~m}^{3}$ cada container, com abrangência de 300 habitantes por ecoponto.

Estes materiais seguem para 3 unidades de triagem, resultando na expedição de papés/cartão, embalagens plásticas, vidro e metal através de contrato com a Sociedade Ponto Verde.

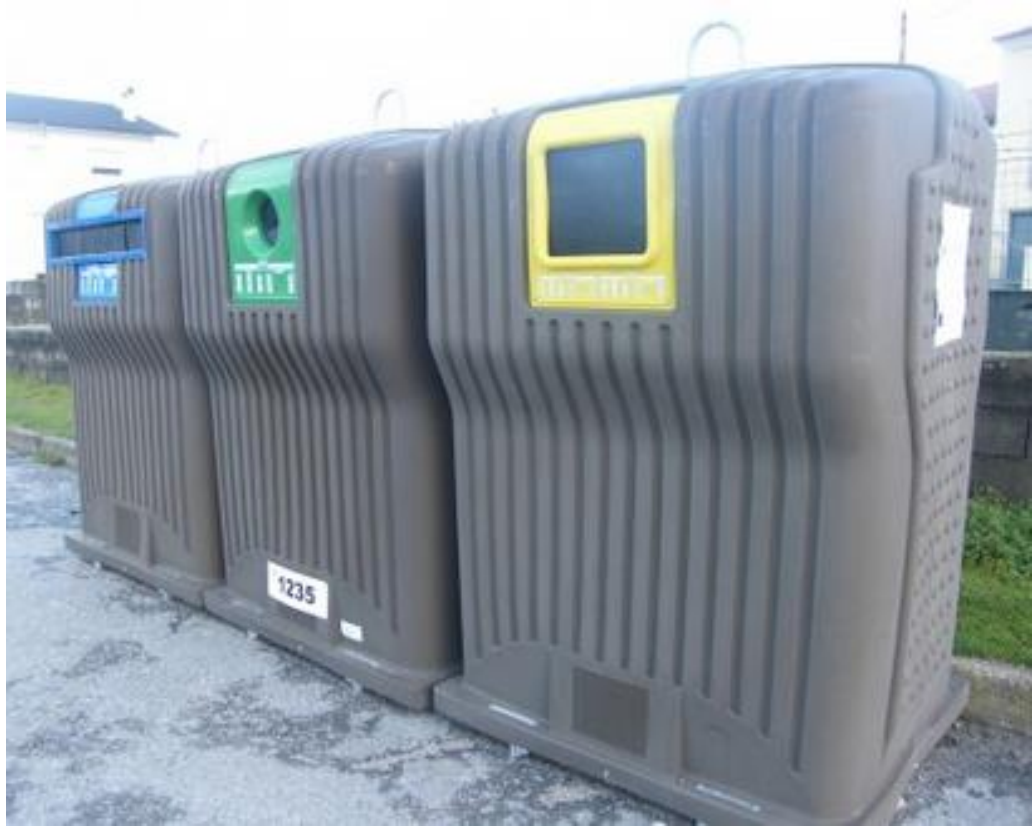

Figura 62 - Fotos de coletores.

Fonte: Relatório Anual Valnor, 2013.

\subsubsection{Resultados}

Em 2013, a unidade tratou 101.663ton de RSU e 8.569ton de resíduos recicláveis, originados da coleta seletiva. Das 101.663ton, 89.026ton foram enviadas ao tratamento mecânico.

Considerando a geração de $1.24 \mathrm{~kg} / \mathrm{dia} / \mathrm{hab}$, de acordo com o PERSU II (2006), esta região gera aproximadamente 121.341 ton/ano, perfazendo então um índice para a coleta seletiva de 7\% do total de RSU e um índice de coleta de $91 \%$, ou seja, 11.109 ton deixaram de ser coletadas e tratadas pelo sistema.

O TMB gerou $31 \%$ de CDR, $9 \%$ de composto, $8 \%$ de embalagens, $2 \%$ de papel e cartão e $1,5 \%$ de metais e vidro e $45 \%$ do volume relacionado a perdas no processo, conforme figura abaixo.

Boa parte do volume alto de perdas envolve embalagens sujas, sem valorização no mercado de reciclagem. Outra parte envolve os gases emitidos, que poderão ser aproveitados para a geração de biogás. 


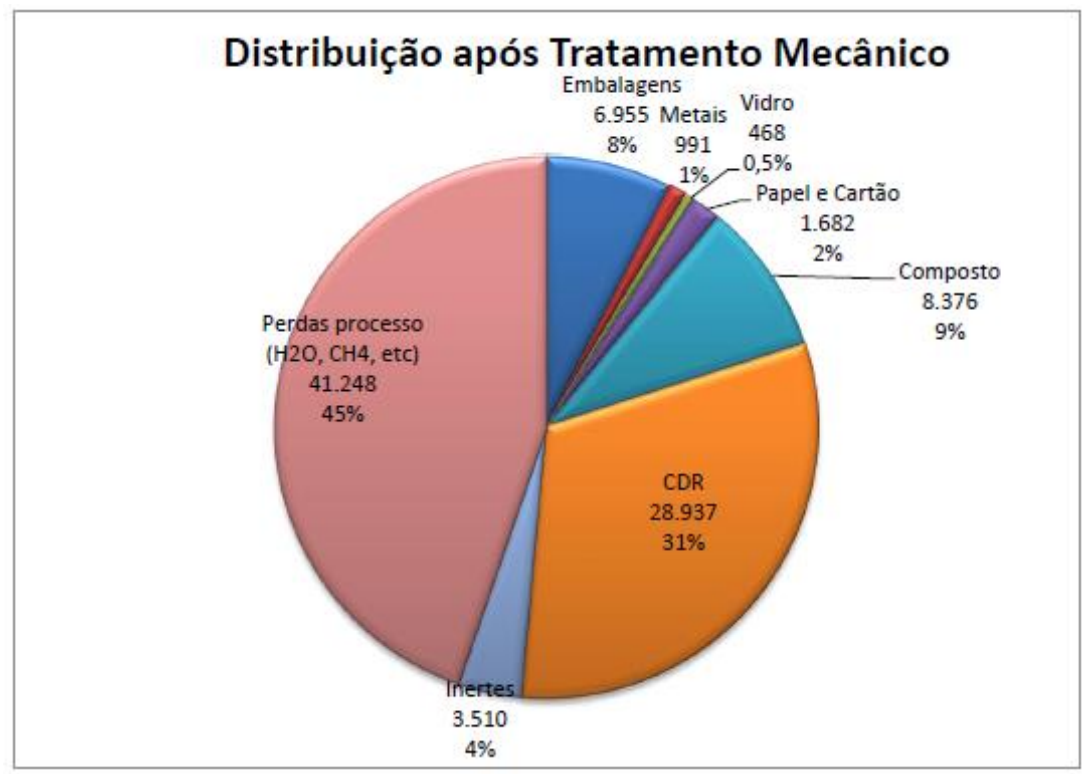

Figura 63 - Distribuição de itens após tratamento mecânico.

Fonte: Relatório Anual Valnor, 2013.

Com o funcionamento da unidade de lavagem e preparação de CDR prevista para 2014, o volume enviado para aterro se reduzirá drasticamente, já que $10 \%$ deste poderá ser aproveitado na reciclagem com a unidade de lavagem e $90 \%$ do restante seguirá para o CDR, gerando energia.

A figura abaixo apresenta os materiais recuperados no tratamento mecânico e seu potencial, apresentando oportunidades de crescimento em todos os tipos de materiais.

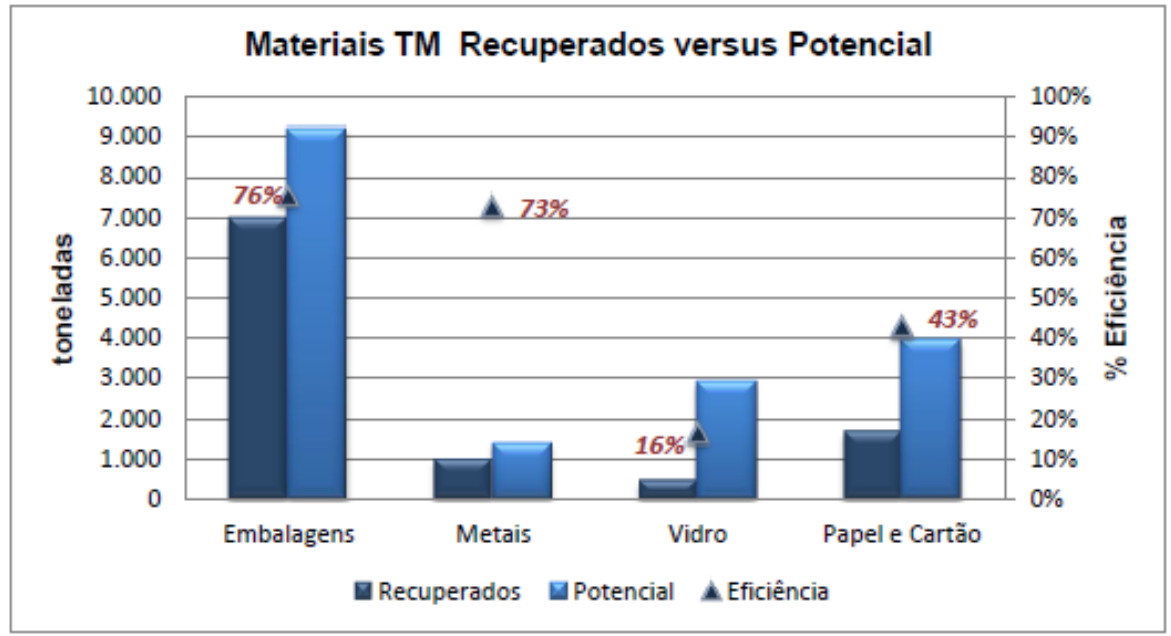

Figura 64 - Comparativo entre material recuperado e potencial. Fonte: Relatório Anual Valnor, 2013.

$\mathrm{Na}$ coleta seletiva, foram recolhidos 4.397 ton de papel/papelão, 2.649 de vidro e 1.523 de embalagens e metais, totalizando 8.569 toneladas de resíduos em 2013, conforme gráfico abaixo. 


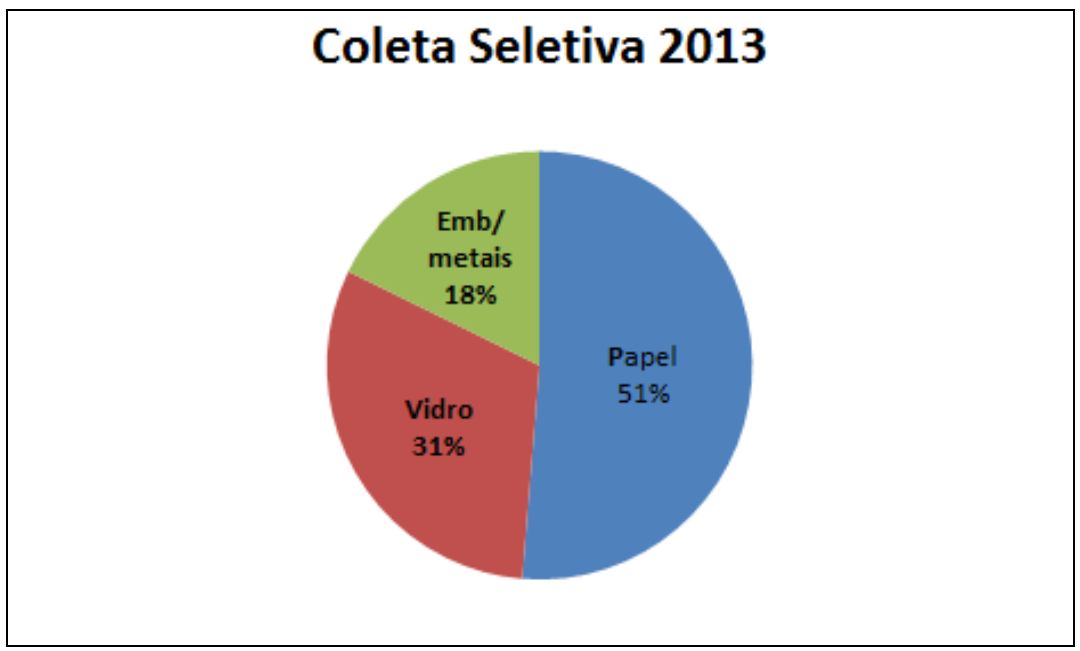

Figura 65 - Resultado da Coleta Seletiva da Valnor.

Fonte: Relatório Anual Valnor, 2013.

No que diz respeito ao sistema de valorização energética do biogás, no aterro sanitário da Concavada verificou-se em 2013 uma produção de energia de $3.230 \mathrm{Mkw}$. A digestão anaeróbia gerou $2.528 \mathrm{Mkw}$, tendo a Valnor produzido/injetado na rede um total de $5.758 \mathrm{Mkw}$, conforme figura abaixo.

\section{VALORIZAÇÃO ENERGÉTICA DIGESTÃO ANAERÓBIA}

\begin{tabular}{ll|l} 
Energia produzida/injetada na rede & 2.528 .521 \\
\hline
\end{tabular}

Biogás tratado nos motores $\left(\mathrm{m}^{3} / \mathrm{ano}\right) \quad 1.625 .686$

Biogás tratado na tocha $\left(\mathrm{m}^{3}\right) \quad 90.035$

$\%$ media metano no Biogás $\quad 57,28$

\section{VALORIZAÇÃO ENERGÉTICA BIOGÁS ATERRO}

Energia produzida/injetada na rede

3.229 .928

Biogás tratado nos motores $\left(\mathrm{m}^{3} / \mathrm{ano}\right)$

1.941 .024

Biogás tratado na tocha $\left(\mathrm{m}^{3}\right)$

14.516

$\%$ media metano no Biogás

Figura 66 - Valorização energética - DA e Aterro Valnor.

Fonte: Relatório Anual Valnor, 2013.

\subsubsection{Análise}

Mesmo com grande volume investido e com quase 10 anos de existência, os resultados obtidos ainda não são satisfatórios, aproveitando-se somente $17 \%$ de itens recicláveis (soma de itens aproveitados no TMB e coleta seletiva) de um total de $55 \%$, de acordo com a composição gravimétrica padrão de países de alta renda (Banco Mundial, 2012).

Pode-se avaliar também que o processo de coleta seletiva ainda precisa de melhoria, já que seu índice é de $7 \%$ frente ao total de resíduos recicláveis gerados, considerando também a composição gravimétrica 
padrão de países de alta renda, de acordo com o relatório do Banco Mundial (2012).

Comparando os resultados do TMB e coleta seletiva (CS) para obtenção de resíduos recicláveis, pode-se concluir que o sistema TMB apresenta melhores resultados para embalagens e metais e a coleta seletiva, para papéis.

\begin{tabular}{|l|r|r|r|r|}
\hline \multicolumn{1}{|c|}{ MATERIAIS } & \multicolumn{1}{|c|}{ TMB } & \% TMB & \multicolumn{1}{c|}{ CS } & \multicolumn{1}{c|}{$\%$ CS } \\
\hline Papel & 1.784 & $2 \%$ & 4.397 & $51 \%$ \\
\hline Vidro & 446 & $9 \%$ & 2.649 & $31 \%$ \\
\hline Embalagens e metais & 8.029 & $1 \%$ & 1.523 & $18 \%$ \\
\hline TOTAL & 89.206 & & 8.569 & \\
\hline
\end{tabular}

Tabela 43 - Comparativo de resultados Valnor no material seco: coleta seletiva e TMB. Fonte: Relatório Anual Valnor, 2013.

Realizando-se ainda uma análise comparativa entre o potencial gerado de resíduos recicláveis de acordo com a composição gravimétrica do Banco Mundial (2012), o gerado no TMB e Coleta Seletiva conforme tabela abaixo, conclui-se que o processo ainda apresenta perda de $38 \%$ ou 46.203 ton/ano, apresentando oportunidades de melhoria tanto no tratamento biológico, como na obtenção de materiais secos.

\begin{tabular}{|l|r|r|r|r|r|r|r|r|}
\hline \multicolumn{1}{|c|}{ MATERIAIS } & \multicolumn{2}{|c|}{ Comp. Grav. } & \multicolumn{2}{|c|}{ TMB } & \multicolumn{2}{c|}{ Col. Seletiva } & \multicolumn{2}{c|}{ Perdas } \\
\hline MO & $28 \%$ & 33.975 & $9 \%$ & 8.029 & & & $76 \%$ & 25.947 \\
\hline Plastico/metal & $17 \%$ & 20.628 & $9 \%$ & 8.029 & $18 \%$ & 1.523 & $54 \%$ & 11.076 \\
\hline Papel & $31 \%$ & 37.616 & $2 \%$ & 1.784 & $51 \%$ & 4.397 & $84 \%$ & 31.435 \\
Vidro & $7 \%$ & 8.494 & $1 \%$ & 446 & $31 \%$ & 2.649 & $64 \%$ & 5.399 \\
Outros & $17 \%$ & 20.628 & $48 \%$ & 43.711 & & & & \\
CDR & & & $31 \%$ & 27.654 & & & & 27.654 \\
\hline TOTAL & $\mathbf{1 0 0 \%}$ & $\mathbf{1 2 1 . 3 4 1}$ & $\mathbf{1 0 0 \%}$ & $\mathbf{8 9 . 6 5 2}$ & $\mathbf{1 0 0 \%}$ & $\mathbf{8 . 5 6 9}$ & $\mathbf{3 8 \%}$ & $\mathbf{4 6 . 2 0 3}$ \\
\hline
\end{tabular}

Tabela 44 - Comparativo de resultados Valnor: coleta seletiva, TMB e potencial. Fonte: Relatório Anual Valnor, 2013.

Como a empresa não disponibilizou os custos separados e detalhados para o processo de coleta seletiva e TM, não há a possibilidade de comparar-se de forma assertiva todos os itens que envolvem os dois processos para a obtenção de materiais secos.

Porém, de forma empírica, podemos pontuar mais vantagens no modelo TMB do que na Coleta Seletiva combinada somente com a destinação para aterro, já que o volume obtido com a matéria orgânica pode ser aproveitado de várias formas, reduzindo o volume enviado para aterro.

O comparativo para a obtenção de metano entre a digestão anaeróbia (DA) e aterro apresenta mais um ponto favorável ao TMB, já que na DA o nível de eficiência para a geração do biogás é maior. 


\subsection{Estudo de Caso - São Paulo - Central Mecanizada de Triagem Carolina Maria de Jesus (EcoUrbis)}

De acordo com a Prefeitura de São Paulo (São Paulo, 2014), a cidade gera, em média, 18 mil toneladas de lixo diariamente (lixo residencial, de saúde, restos de feiras, podas de árvores, entulho, etc.). São coletados quase $10 \mathrm{mil}$ toneladas por dia de resíduos domiciliares.

Os serviços de coleta, transporte e destinação adequada de resíduos domiciliares e hospitalares, além da coleta seletiva é executada por duas concessionárias, Ecourbis e Loga, cada uma atendendo $50 \%$ da população da cidade, com áreas de atuação delimitadas, conforme abaixo.

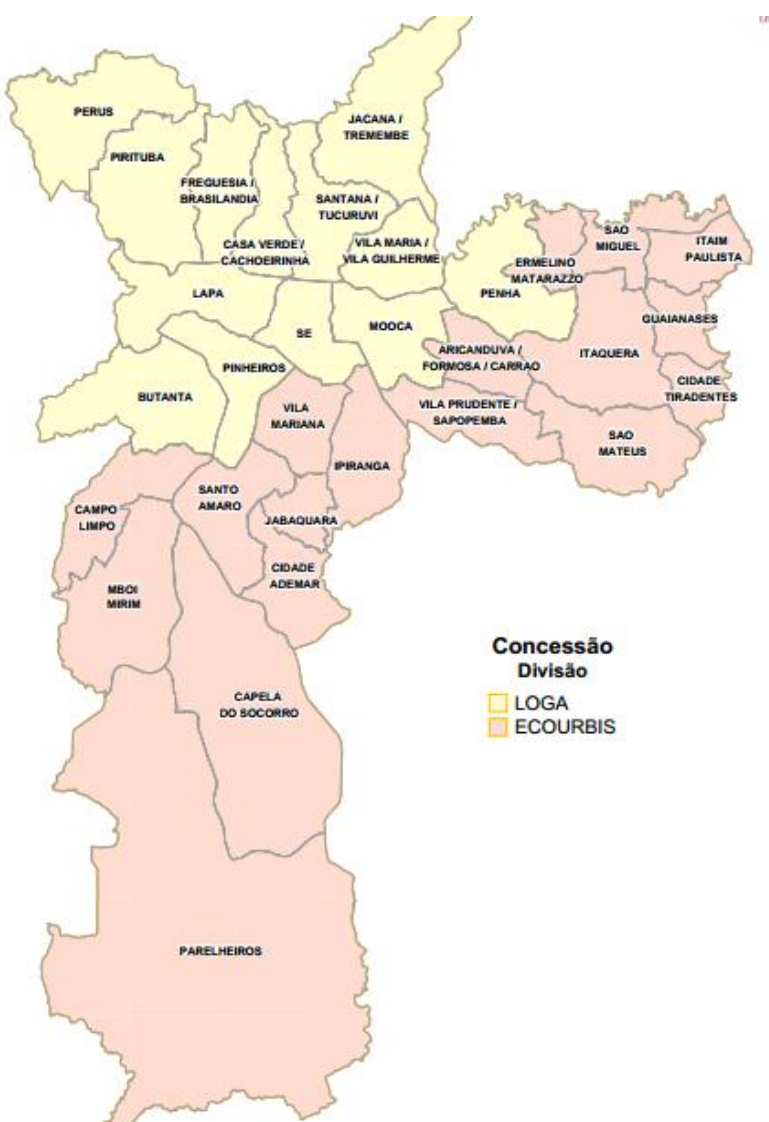

Figura 67 - Mapa Coleta de Lixo Domiciliar - Cidade de São Paulo. Fonte: Prefeitura de São Paulo, 2014.

Loga - responsável pelos resíduos gerados nas zonas Oeste, Norte, Centro e parte da Leste. Total de 19 das 32 subprefeituras da cidade.

Ecourbis - responsável pelos resíduos gerados nas zonas Sul e parte da Leste, total de 13 subprefeituras restantes da cidade.

O processo de gestão conta com 3 estações de transbordo: Transbordo Vergueiro, Transbordo Santo Amaro, Transbordo Ponte Pequena.

Estes são pontos de destinação intermediários dos resíduos coletados na cidade, criados em função da considerável distância entre a área de 
coleta e o aterro sanitário. As estações de transbordo são locais onde o lixo é descarregado dos caminhões compactadores e posteriormente colocado em uma carreta, levando os resíduos até o aterro sanitário.

A cidade conta também com cinco Áreas de Transbordo e Triagem (ATTs) de resíduos de construção civil privadas.

Atualmente, há 2 aterros sanitários em funcionamento: a Central de Tratamento de Resíduos Leste (CTL), controlado pela Ecourbis, localizado na Cidade Satélite Santa Bárbara e recebe os resíduos gerenciados pela Ecourbis.

O Aterro de Caieiras, controlado pela Essencis Ambiental, localiza-se no noroeste da Região Metropolitana de São Paulo e recebe o material controlado pela Loga.

A cidade gerencia também 2 aterros desativados: o aterro sanitário Bandeirantes (desativado desde o mês de março de 2007, ainda com captação de gás) e o aterro São João (desativado desde o ano de 2009).

O Programa de Coleta Seletiva da Prefeitura de São Paulo conta atualmente com 20 Centrais de Triagem que possibilitam a geração de renda, emprego e inclusão social para cerca de 1.200 pessoas, de 20 cooperativas conveniadas, perfazendo o índice de $2 \%$ sobre o total coletado.

A Prefeitura pretende aumentar este índice para $10 \%$, implantando quatro novas centrais mecanizadas de triagem de materiais recicláveis ao custo de 20 milhões de reais cada (ROSSETO, 2013).

Duas destas centrais foram inauguradas em 2014: A Central de Resíduos Ponte Pequena, sob responsabilidade da Loga e a Central Mecanizada de Triagem Carolina Maria de Jesus (CTM), sob responsabilidade da EcoUrbis, foco deste estudo de caso.

A CTM tem área total da Central de $4.800 \mathrm{~m}^{2}$, possui capacidade nominal para processamento de 250ton/dia, operando com 7 funcionários EcoUrbis e 50 cooperados. Esta unidade processa somente resíduos originados da coleta seletiva.

Para a inauguração desta Unidade, a EcoUrbis investiu 33 milhões de reais, valor que inclui a compra de equipamentos, bem como a instalação predial.

Este valor foi integralmente pago por esta empresa, que será ressarcido pela Prefeitura de São Paulo, de acordo com o contrato de concessão de 20 anos (duração do contrato até 2024). Este contrato não prevê cobrança de taxa ao cidadão. 
Inaugurada em julho de 2014 , a unidade atualmente processa $16 \%$ de sua capacidade instalada (40ton/dia - em 2 turnos), já que seu limitador atual é o volume recebido da coleta seletiva.

Das 40 toneladas diárias, a unidade aproveita $60 \%$ do volume, que seguem para gestão de 50 cooperados, trabalhando dentro das instalações da EcoUrbis.

Estes realizam a triagem manual dos resíduos, última fase do processo. Os resíduos seguem para a comercialização com atravessadores, realizada diretamente pelos cooperados.

Toda a receita obtida neste processo é destinada à Cooperativa. De acordo com os cooperados, é possível retirar aproximadamente $\mathrm{R} \$ 1.000,00$ mensais por pessoa.

Isto quer dizer que o processo gera aproximadamente $R \$ 50.000,00$ mensais de faturamento. Não foi possível obter demais informações sobre custos e lucratividade da unidade, devido ao seu tempo de operação.

Os $40 \%$ de resíduos não aproveitados seguem diretamente para o aterro sanitário Central de Tratamento de Resíduos Leste (CTL).

O processo de separação mecânica conta com 9 principais equipamentos e 16 fases, conforme abaixo.

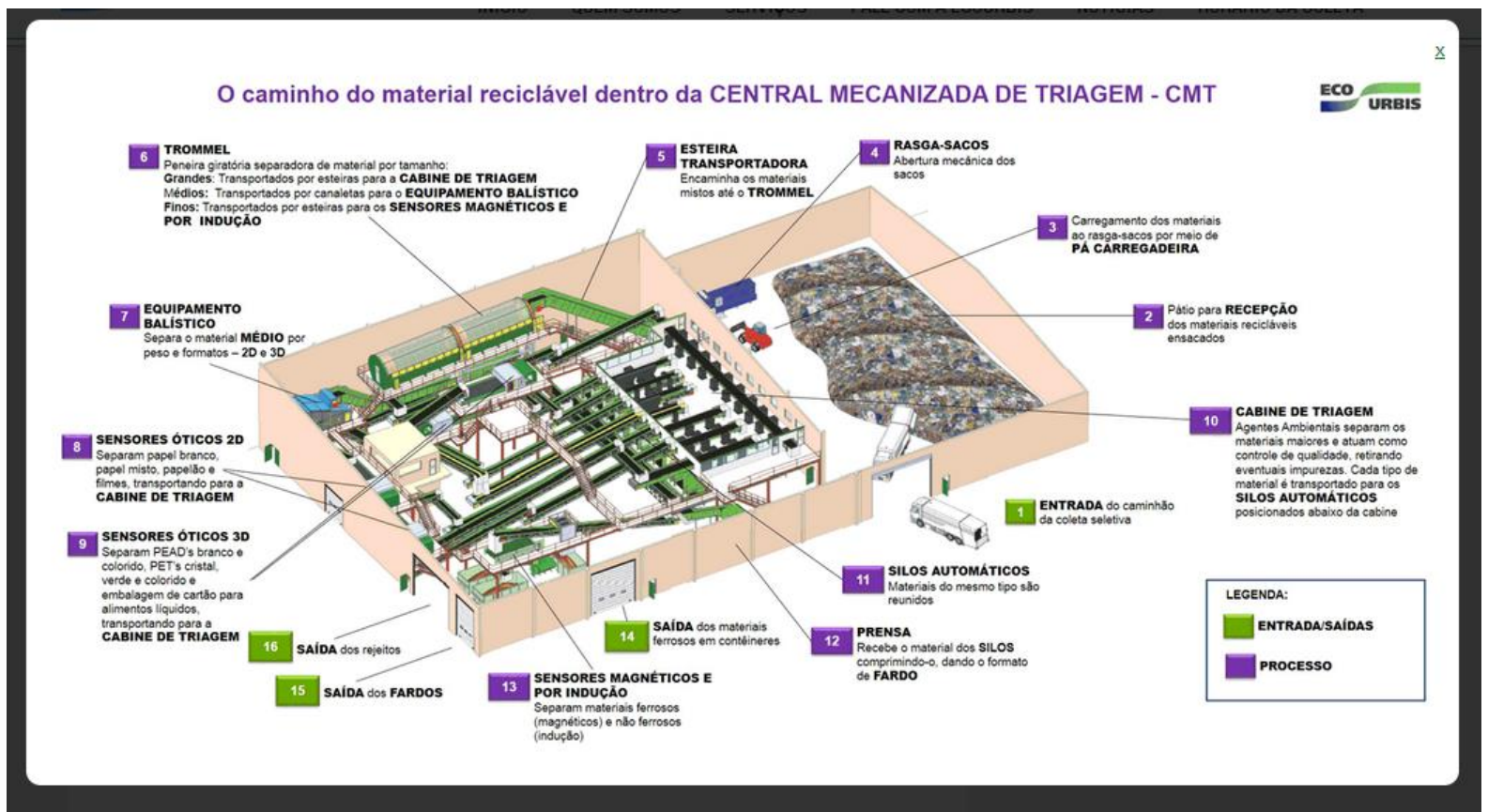

Figura 68 - Fluxo Esquemático do processo na CMT.

Fonte: Ecourbis, 2014.

Quase toda a linha não possui envolvimento de pessoas. Há separação manual no passo 4 (Rasga Sacos) para triagem de itens volumosos, como pedaços de equipamentos eletrônicos e mobiliário, frequentes no processo. Utiliza-se neste ponto 2 cooperados por turno. 
Os restantes dos cooperados ficam alocados no passo 10 (Cabine de triagem), realizando a última fase de separação dos resíduos.

Os 7 funcionários EcoUrbis citados anteriormente executam as seguintes funções: um eletricista, um analista de produção, um mecânico, dois ajudantes e dois operadores do painel de controle.

Os principais resíduos separados e comercializados por esta Unidade são papel, plástico e itens metálicos. Todo o vidro e demais materiais são dados como rejeitos.

\section{Resultados, desafios e pontos de melhoria}

Ainda é cedo para se analisar o processo na cidade de São Paulo, já que este possui somente 2 meses de operação. De acordo com fatos e estudos anteriores, pode-se considerar as dificuldades que serão enfrentadas para a utilização de toda a capacidade nominal de processamento e do atingimento de metas previstas somente, com o resultado da coleta seletiva.

Os principais desafios encontrados neste processo são o incremento do volume coletado e melhor aproveitamento dos resíduos recebidos.

Para incremento do volume coletado, é preciso revisão no processo Logístico, bem como a compra de novos veículos. Estes pontos são de responsabilidade da EcoUrbis, que prevê a inclusão de mais 10 veículos compactadores a partir de outubro no processo de coleta seletiva, ainda sem números previstos para o volume resultante.

Além dos pontos comentados acima, o motivo de maior impacto no volume coletado é o nível de conscientização/comprometimento dos cidadãos, que conforme abordado anteriormente, necessita de alto investimento, bem como de grande envolvimento do poder público. Neste ponto, resultados de grande relevância serão visualizados a longo prazo, conforme cálculo abaixo.

Se a cidade produz 10.000ton/dia de resíduos, apresentando a composição gravimétrica média brasileira, o potencial a reciclar seria de 3.000 ton/dia (30\% de itens recicláveis - Cempre, 2010).

A meta indicada pela Prefeitura é de $10 \%$, que seria exatamente o que as 4 unidades produziriam (EcoUrbis + Loga), se recebessem $100 \%$ da capacidade produtiva (250ton/dia) e utilizassem todo o resíduo recebido e não somente os $60 \%$ atuais.

É importante lembrar que atualmente recebe-se somente $16 \%$ da capacidade produtiva, aproveitando-se somente $60 \%$ deste volume. 
Para a melhoria dos resultados, é importante melhorar a gestão do processo de comercialização e tratamento de resíduos, atualmente sob responsabilidade dos cooperados, pessoas sem muita informação técnica e capacitação em gestão. 


\section{CONSIDERAÇÕES FINAIS}

O município do Rio de Janeiro apresenta fraquezas representativas para o atendimento das metas de tratamento de resíduos sólidos em curto e médio prazo, como a dependência da coleta seletiva para a obtenção de materiais para a reciclagem, o alto custo logístico envolvido nesta operação, bem como o baixo nível de conhecimento em práticas de gestão e comprometimento com resultados a partir dos catadores de material reciclável.

Desta forma, o tratamento mecânico e biológico apresenta-se como uma solução tecnológica que poderá aumentar os níveis de reciclagem, atendendo à hierarquia de destinação dos resíduos prevista na PNRS. A utilização do TM para a separação dos RSU's apresenta ganhos logísticos representativos, assim como o incremento imediato no volume de materiais recuperados, bem como a redução de resíduos enviados ao aterro sanitário. Já o TB é responsável pela geração de energia a partir da matéria orgânica. Por estes motivos, O TMB pode ser considerado uma ferramenta para o atendimento das metas estipuladas na Política e seus desdobramentos estaduais e municipais.

Esta tecnologia busca o atendimento de metas em curto prazo, apresentando também vantagem no que envolve 0 volume de investimento de acordo com o perfil político brasileiro.

O maior percentual do investimento será aplicado no início do projeto, demandando somente custos de manutenção para anos posteriores, facilitando sua continuidade com a sucessiva troca de mandatos políticos. Enquanto que na coleta seletiva, a continuidade da gestão fica comprometida, uma vez que há necessidade de investimento frequente.

O alto investimento inicial é a principal dificuldade para implantação do TMB. Como este tipo de tratamento ainda não foi utilizado no Brasil, a análise de custos e investimentos ficou pautada em pesquisas bibliográficas a partir de países que não apresentam a mesma composição gravimétrica do lixo que o Brasil. Sendo assim, o estudo sugere aprofundamento na análise de viabilidade econômica.

Por este motivo, tal tecnologia não poderá ser utilizada para municípios de pequeno e médio porte, adequando-se aos de grande porte ou a soluções consorciadas.

A atividade nas plantas de TMB apresenta outras oportunidades de trabalho no envolvimento no processo produtivo, gerando capacitação para operação em máquinas e equipamentos, aumentando o leque de oportunidade destas pessoas para trabalho em outras atividades.

O estudo sugere a formação de parcerias entre os municípios com órgãos de orientação a pequenos empresários, como o SEBRAE. 
Além disso, é importante também um envolvimento político para a revisão da tributação de itens reutilizados ou reciclados, bem como a desburocratização do processo de comercialização de recicláveis.

Recomenda-se uma análise mais detalhada a respeito de todos os custos envolvidos, tanto no cenário atual do município do Rio de Janeiro, como no investimento e custos previstos na implantação da planta TMB, estabelecendo um comparativo dos seguintes itens: custo logístico, faturamento com a comercialização de biogás, de CDR e de composto, bem como os custos de operação de cada unidade de triagem, tratamento e destinação final.

Os impactos sociais decorrentes da implantação desta tecnologia apresentada neste estudo deve ser objeto de aprofundamento, aliando o emponderamento incentivado na PNRS a novas formas de trabalho com a aplicação do TMB nas Unidades de Triagem.

Outras oportunidades para aprofundamento são a aplicação do TMB para municípios de pequeno porte, bem como a digestão anaeróbica na gestão dos resíduos orgânicos em condomínios ou pequenos logradouros.

Destaca-se a importância do estabelecimento de taxas de gestão de resíduos a serem cobradas aos munícipes e de forma diferenciada aos grandes geradores, devendo ser avaliada a melhor forma para a sua implementação, com base nos impactos sociais, ambientais e econômicos. 


\section{REFERÊNCIAS BIBLIOGRÁFICAS}

ABRAMOVAY, RICARDO; SPERANZA, JULIANA; PETITGAND, CECILE. Lixo Zero. Gestão de Resíduos para uma Sociedade Próspera. São Paulo. Planeta sustentável : Instituto Ethos, 2013.

ABRELPE. PANORAMA DOS RESÍDUOS SÓLIDOS NO BRASIL. São Paulo, 2013.

ABRELPE. Atlas Brasileiro de Emissões de GEE e Potencial Energético na Destinação de Resíduos Sólidos. 2012.

ANAP - Associação Nacional de Aparistas de Papel. Relatório Anual ANAP 2012.

AGNES, MAIER. MBT Mechanical-Biological Treatment Of MMSW Mixed Municipal Solid Waste: Experience In Austria And Portugal. ISWA Review. 2010.

ABREU,FABIO VIANA; SOUZA, MAURO CARLOS LOPES et, al. Avaliação técnica e econômica da geração de energia do biogás nos aterros de Gramacho e Seropédica. Revista AS\&T, Volume 2, Junho 2014.

ALENCAR, EMANUEL. Por dia, Região Metropolitana do Rio enterra $\mathrm{R} \$ 950 \mathrm{mil}$ em recicláveis. Blog Verde. Disponível em http://www.mundosustentavel.com.br/2012/09/pordia-regiao-metropolitana-do-rio-enterra-r-950-mil-em-reciclaveis. Acesso em 20/09/2012.

ALENCAR, EMANUEL. Comlurb e BNDES apresentam termo de referência sobre coleta seletiva no Rio. Disponível em: http://www.rio.ri.gov.br/web/comlurb/exibeconteudo?article-id=2408276. , Acesso em 19/09/2012.

ASSOCIAÇÃO BRASILEIRA DE NORMAS TÉCNICAS. NBR 10004. Resíduos Sólidos: Classificação. Rio de Janeiro, 2004.

ASSOCIAÇÃO BRASILEIRA DE NORMAS TÉCNICAS. NBR 6023. Elaboração de Referências. Rio de Janeiro, 2000.

ASSOCIAÇÃO BRASILEIRA DE NORMAS TÉCNICAS. ABNT NBR 15448-2. Embalagens plásticas degradáveis e/ou de fontes renováveis - Parte 2: Biodegradação e compostagem - Requisitos e métodos de ensaio. Rio de Janeiro, 2008.

AZEVEDO. R. F.; CARVALHO. A. R.: AZEVEDO. I. C. D.: MARQUES. E. A. G.. Variação com a idade de características dos resíduos do aterro sanitário de Santo André, São Paulo. V CONGRESSO BRASILEIRO DE GEOTECNIA AMBIENTAL. REGEO 2003, Porto Alegre, 2003.

BASTOS,VALÉRIA PEREIRA. Catador: profissão. Um estudo do processo de construção identitária, do catador de lixo ao profissional catador. Jardim Gramacho, de 1996 aos dias atuais. Tese apresentada ao Programa de Pós-Graduação em Serviço Social do Departamento de Serviço Social da PUC-Rio. Rio de Janeiro, 2008.

BASTOS,VALÉRIA PEREIRA. Jardim Gramacho e os catadores de material recicláveis: território extraordinário do lixo. Rio de Janeiro, 2012.

BIDONE, Francisco Ricardo Andrade. Povinelli, Jurandyr. Conceitos básicos de resíduos sólidos. São Carlos, SP : EESC-USP, 1999.

BIDONE, Francisco Ricardo Andrade (org.). Metodologia e Técnicas de Minimização, Reciclagem e Reutilização de Resíduos Sólidos Urbanos. Rio de Janeiro: ABES Associação Brasileira de Engenharia Sanitária e Ambiental, 1999. 65 p. 
BRASIL. CONAMA № 1 de 23 de janeiro de 1986. Dispõe sobre critérios básicos e diretrizes gerais para a avaliação de impacto ambiental.

BRASIL. CONAMA № 275 de de 25 de abril de 2001. Estabelece o código de cores para os diferentes tipos de resíduos, a ser adotado na identificação de coletores e transportadores, bem como nas campanhas informativas para a coleta seletiva.

BRASIL. Plano Nacional de Resíduos Sólidos. Versão Preliminar para Consulta Pública. Brasília, setembro de 2011.

BRASIL. Lei Federal no 11.445, de 05 de janeiro de 2007. Estabelece diretrizes nacionais para o saneamento básico.

BRASIL. Lei Federal no 12.305, de 02 de agosto de 2010. Dispõe sobre Política Nacional de Resíduos Sólidos.

BRASIL. Lei Federal o 11.107, de 06 de abril de 2005, Dispõe sobre normas gerais de contratação de consórcios públicos.

BRASIL. Rio de Janeiro. Lei Municipal $n^{\circ} 4.969$, de 03 de dezembro de 2008. Lei Municipal de Gestão de Resíduos Sólidos.

BRASIL. Rio de Janeiro.Lei Municipal № 5.248, de 27 de janeiro de 2011. Institui a Política Municipal sobre Mudança do Clima e Desenvolvimento Sustentável.

BRASIL. Rio de Janeiro. Decreto Municipal $n^{\circ} 31.416$ de 30 de novembro de 2009. Determina que o Plano de Gestão Integrada de Resíduos Sólidos PGIRS Público considere os objetivos de redução de emissão de gases de efeito estufa na cidade do Rio de Janeiro.

BRASIL. Rio de Janeiro. Decreto Municipal o 37.775 de 10 de outubro de 2013. Institui o Plano Municipal de Gestão Integrada de Resíduos Sólidos - PMGIRS da Cidade do Rio de Janeiro

BRASIL. Rio de Janeiro. Lei 5.248, de 27 de Janeiro de 2011. Institui a Política Municipal sobre Mudança do Clima e Desenvolvimento Sustentável, dispõe sobre o estabelecimento de metas de redução de emissões antrópicas de gases de efeito estufa para o Município do Rio de Janeiro.

BRASIL. Rio de Janeiro. Lei oㅜ 4.191, de 30 de setembro de 2003. Estabelece a Política Estadual de Resíduos Sólidos.

BRASIL. Rio de Janeiro. Resolução CONEMA no 55 de 13 de dezembro de 2013. ESTABELECE PROCEDIMENTO DE DIFERENCIAÇÃO MÍNIMA DE CORES PARA A COLETA SELETIVA SIMPLES DE RESÍDUOS SÓLIDOS URBANOS E DE RESÍDUOS DE ESTABELECIMENTOS COMERCIAIS E PRESTADORES DE SERVIÇOS, A SER ADOTADO NA IDENTIFICAÇÃO DE COLETORES E VEÍCULOS TRANSPORTADORES, PARA A SEPARAÇÃO DE RESÍDUOS NO ESTADO DO RIO DE JANEIRO.

CAPELLINI, Marcia. Potencialidade e aplicação da prevenção de resíduos de embalagens: abordagem sobre o projeto do produto e o consumo. Tese de Doutorado apresentada à Escola de Engenharia de São Carlos da Universidade de São Paulo. São Carlos, 2007.

CARVALHO, M. F. (1999), Comportamento Mecânico de Resíduos Sólidos Urbanos. São Paulo. 1999. 300p. Tese (Doutorado) - Escola de Engenharia de São Carlos, Universidade de São Paulo. 
CEMPRE REWIEW, São Paulo, 2013.

CETESB. Estimativas anuais de emissões de gases de efeito estufa no Brasil. Brasília, 2013.

COMETTI, Any. Resíduos sólidos: entidades municipalistas tentam evitar punição de prefeitos. Matéria publicada em 19/08/2014. Disponível em http://seculodiario.com.br/18351/10/residuos-solidos-entidades-municipalistas-tentamevitar-punicao-de-prefeitos-1 - retirado em 17/09/2014.

COSTA, João Pedro Fidalgo. TRATAMENTO MECÂNICO E BIOLÓGICO DE RESÍDUOS SÓLIDOS URBANOS: AVALIAÇÃO DO SEU POTENCIAL PARA A RECUPERAÇÃO DE MATERIAIS RECICLÁVEIS. Relatório de Estágio de Mestrado em Ecologia Humana e Problemas Sociais Contemporâneos. Universidade de Lisboa. 2010.

ECOLOGUS. Relatório de Consultoria à SEA para Elaboração do Plano Estadual de Resíduos Sólidos do Rio de Janeiro. 2013.

ENVIROS. Enviros Consulting Limited. Incineration of Municipal Solid Waste. DEFRA Department of Environment, Food and Rural Affairs. London, 2007.

EPE, Empresa de Pesquisa Energética. Nota Técnica DEN 13/14. Estudos de Demanda de Energia 2050. Ministério de Minas e Energia, 2014.

EPE, Empresa de Pesquisa Energética. Nota Técnica DEN 06/08. Aproveitamento Energético de RSU em Campo Grande, MS. Ministério de Minas e Energia, 2008.

FONTI, Angela. Comlurb: legado de Gramacho à CTR-Rio. Apresentação para a Rio Ambiente 2012. Rio de Janeiro, junho 2012.

FONTI, Angela. Gestão de Resíduos no Rio de Janeiro: Case Comlurb. Apresentação para a Rio Ambiente 2011. Rio de Janeiro, julho 2011.

GLR - Recommendations Geotechnics of landfill design and remedial works, "Technical Recommendations", edited by the German Geotechnical Society for the International Society of Soil Mechanics and Foundation Engineering. Ernst \& Sohn, Berlin, 1993.

IBAM. INSTITUTO BRASILEIRO DE ADMINISTRAÇÃO MUNICIPAL. Manual de Gerenciamento Integrado de Resíduos Sólidos. Rio de Janeiro, 2001.

IPEA. Diagnostico dos Resíduos Sólidos Urbanos. Relatório de Pesquisa. 2012.

IPT, 2000. Manual de Gerenciamento Integrado do Lixo. $2^{\text {a }}$ Edição. São Paulo. IPT/CEMPRE. 2000. 370p.

INSTITUTO DE PESQUISAS TECNOLÓGICAS DO ESTADO DE SÃO PAULO (IPT). Lixo Municipal: manual de gerenciamento integrado. São Paulo: IPT/CEMPRE. 1995. 278p.

ISWA. Resíduos Sólidos: Manual de Boas Práticas de Planejamento. 2010. 107p.

JACOBI, PEDRO. Org. Gestão Compartilhada de resíduos sólidos no Brasil: inovação com inclusão social. São Paulo: Annablume, 2006.

JUNIPER. Mechanical-Biological-Treatment: A Guide for Decision Makers Process, Policies and Markets. UK, 2005. 
KNOCHENMUS, G.: WOJNAROWICZ, M. \& VAN IMPE (1998). Stability of Municipal Solid Wastes, In: Proc. of the Third International Congress on Environmental Geotechnics. Lisboa, Portugal. Séco e Pinto (ed.). Balkema, Rotterdam, p.977-1000.

LEITE, J.C. Metodologia para Elaboração da Carta de Susceptibilidade à Contaminação e Poluição das águas Subsuperficiais. São Paulo. 1995. 219p. Dissertação de Mestrado. Escola de Engenharia de São Carlos. Universidade de São Paulo.

LINDON D., LENDREVIE J., LÉVY J., DIONÍSIO P., RODRIGUES J., Mercator XXI Teoria e prática do Marketing, 10. e edição, Lisboa: Dom Quixote, 2004

MAMEDE, Maurício Cuba dos Santos. Avaliação Econômica e Ambiental do Aproveitamento Energético de Resíduos Sólidos no Brasil. Campinas, 2013. 141p. Dissertação de Mestrado. Faculdade de Engenharia Mecânica. Universidade Estadual de Campinas.

NASCIMENTO, JULIO CESAR FIALHO DO. Comportamento mecânico dos resíduos sólidos urbanos. Universidade de São Carlos, 2007.

NASCIMENTO, JUSSARA OLIVEIRA DO. Avaliação de Impactos Sociais e Ambientais a partir do fechamento do Aterro Metropolitano de Jardim Gramacho. III Simposio de Pós Graduação em Engenharia Urbana. Paraná. Novembro, 2012.

OLIVEIRA, Maria Clara Brandt Ribeiro de Oliveira. Gestão de Resíduos Plásticos PósConsumo: Perspectivas para a Reciclagem no Brasil. Dissertação de Mestrado apresentada ao Programa de Pós -Graduação em Planejamento Energético , COPPE, da Universidade Federal do Rio de Janeiro. 2012.

PINTO, C. S. (2000). Curso Básico de Mecânica dos Solos. Editora Oficina de Textos.

PORTUGAL. MINISTÉRIO DO AMBIENTE. PERSU II - Plano Estratégico para Resíduos Sólidos Urbanos. Portugal, 2006.

PUC. Normas para Apresentação de Teses e Dissertações. 2001.

PROSAB. PROGRAMA DE PESQUISA EM SANEAMENTO BÁSICO. Resíduos Sólidos. Estudo de Caracterização e Tratabilidade de Lixiviados em Aterros Sanitários para as Condições Brasileiras. São Leopoldo, RS. 2009.

SAROLDI, Maria José L. de Araújo. Termo de Ajustamento de Conduta na Gestão de Resíduos Sólidos. Rio de Janeiro: Editora Lumen Juris, 2005.

SASSE, Julia. A disposição de lixo na Alemanha: alternativas para um programa brasileiro da administração do lixo. Impulso. Revista de Ciências Sociais e Humanas. Unimep, 2002.

SCHALCH, V. Análise Comparativa do Comportamento de Dois Aterros Sanitários e Correlações dos Parâmetros do Processo de Digestão Anaeróbia. 1992. 220p. Tese (Doutorado) - Escola de Engenharia de São Carlos. Universidade de São Paulo.

SEA. SECRETARIA DE ESTADO DO AMBIENTE. Governo do Estado do Rio de Janeiro. PERS. PLANO ESTADUAL DE RESÍDUOS SÓLIDOS. Rio de Janeiro, 2013.

SILVEIRA, Ana Maria de Miranda. Estudo do Peso Específico de Resíduos Sólidos Urbanos. Tese apresentada ao Programa de Pós-Graduação de Engenharia da Universidade Federal do Rio de Janeiro. 2004.

SMAC/SECONSERVA/COMLURB. Plano Municipal de Gestão Integrada de Resíduos Sólidos - PMGIRS da Cidade do Rio de Janeiro. 2012. 
STEPHANIE, Thiel; KARL Joachim. Mechanical Biological Pre-Treatment of Waste Hope and Reality. ISWA Review. 2011.

STEPHANOU, João. Gestão de Resíduos Sólidos: Um Modelo Integrado que gera benefícios econômicos, sociais e ambientais, 2013. Disponível em http://www.ufrgs.br/sustentabilidade, retirado em 02/09/2014.

TCHOBANOGLOUS, G.: THEISEN. H.: VIGIL, S. (1993). Integrated Solid Waste Management Engineering Principles and Management Issues. McGraw-Hill, Inc. 1993. 978p.

TEIXEIRA, NÁDIA ALVES RIBEIRO - Recuperação de Resíduos de Embalagem através do Tratamento Mecânico e Biológico em Portugal Continental - Dissertação de mestrado apresentada na Faculdade de Ciências e Tecnologia da Universidade Nova de Lisboa Portugal, 2009.

TUFANO, Douglas. Guia Prático da Nova Ortografia. Agosto 2008. Ed Melhoramentos. São Paulo, SP, Brasil.

VALNOR. Relatório \& Contas 2013. Portugal, 2013.

VALNOR. Declaração Ambiental 2006. Portugal, 2007.

VILHENA. A; D'ALMEIDA. M. L O. Processamento do lixo: segregação dos materiais. In: Lixo municipal: manual de gerenciamento integrado. IPT-Instituto de Pesquisas Tecnológicas, CEMPRE - Compromisso Empresarial para Reciclagem. 2000. p. 81-89.

World Bank (2012). "What a waste. A global review of solid waste management".a partir de, acessado em 03/09/2014.

http://web.worldbank.org/WBSITE/EXTERNAL/TOPICS/EXTSDNET/0,,contentMDK:2321 2147 menuPK:64885113 pagePK:7278667 piPK:64911824 theSitePK:5929282,00.htm ।

\section{SITES CONSULTADOS}

http://www.usinaverde.com.br/ - acessado em 03/09/2014.

http://www.braskem.com.br/site.aspx/FAQ_PeVerde - acessado em 02/09/2014.

http://bracelpa.org.br - Associação Brasileira de Celulose e Papel - acessado em 03/09/2014.

http://www.inp.org.br/pt/oxidegradacao.asp - Insitituto Nacional do Plástico - acessado em 04/09/2014.

http://www.prefeitura.sp.gov.br - Plano de Gestão de Resíduos da Cidade de São Paulo. Acesso em 16/09/2014.

http://www.ecourbis.com.br - acessado em 16/09/2014.

http://www.cetesb.sp.gov.br/residuos-solidos/documentos/14-relatorio-iqr - Acesso em $16 / 09 / 2014$

http://www.coletaseletivasolidaria.com.br/ - Acesso em 03/11/2014.

http://www.rj.gov.br/web/sea/exibeconteudo?article-id=1917538 - Programa Catadores e Catadoras em Redes Solidárias. Acesso em 04/10/2014. 


\section{APÊNDICE A - Relatório de Pesquisa de Campo - Unidade de Triagem Irajá.}

NOME DO ENTREVISTADO: Evelyn Marcele de Brito.

CARGO: Líder da Cooperativa Coopama.

DATA DA VISITA : 08/07/2014.

CONTEÚDO ABORDADO:

- A unidade opera com 42 pessoas (somente em 1 turno), ligadas a 5 cooperativas: ACMR (Coelho Neto), Coopama (Maria da Graça), Quitungo (Vila da Penha), Tubiacanga (Ilha do Governador) e Ecomplex (Complexo do Alemão).

- Produção semanal de 12ton de resíduos valorizados para a reciclagem, conforme distribuição abaixo:

- Papel - 4.500 ton

- Plásticos pesados (PET, PEAD, outros) - 3.000ton

- Plásticos leves (filme, PVC) - 1.000ton

- Sucata - 1000 ton

- Origem dos resíduos: veículos da Comlurb, originados da coleta seletiva.

- Com os resíduos acima, os cooperados conseguem retirar 1 salário mínimo. Os lideres das cooperativas conseguiram também cestas básicas para todos os cooperados, através de um programa social da Comunidade da Mangueira.

- Recursos:

- O local é de propriedade da Comlurb, bem como alguns equipamentos. É de responsabilidade da Comlurb também o pagamento de contas como energia elétrica, água e telefone, bem como gastos com manutenção dos equipamentos.

- As Cooperativas recebem também recursos do BNDES e Coca Cola (equipamentos).

\section{- Descrição do processo}

$\circ A^{\underline{a}}$ e $2^{\underline{a}}$ triagem têm por objetivo a retirada de itens volumosos e de alto valor pessoal (como roupas, sapatos, assessórios), que reduzem o nível de atenção dos funcionários das esteiras, baixando a produtividade;

- Na esteira automática localizam-se 5 cooperadas, cada uma com reponsabilidade de catar 2 tipos de resíduos;

- A 3 ${ }^{a}$ triagem retira mais itens volumosos e de alto valor;

- O processo na esteira manual é mais demorado e exige mais cooperados em operação;

- Após as separações manuais, os resíduos recicláveis (papel, plástico, metal e vidro) armazenados em Bag's são enviados às prensas para criação de fardos, seguindo para o local de armazenagem. Neste local, aguardam o processo de comercialização para entrega aos atravessadores;

- Sucatas e materiais diversos também são armazenados, aguardando o processo de comercialização para entrega aos atravessadores; 
- Os rejeitos (matéria orgânica, resíduos de construção civil dentre outros) são enviados aos destinos ambientalmente corretos.

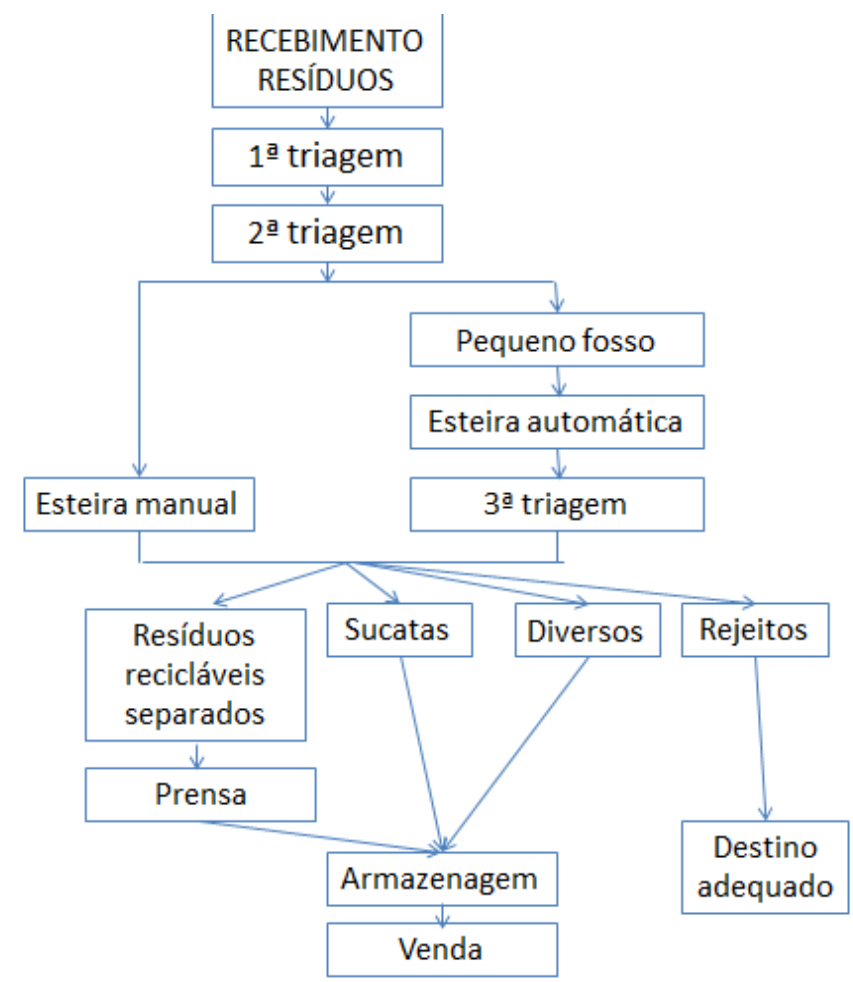

Figura 69 - Fluxo de Operação na Unidade de Triagem de Irajá

- A Unidade possui 2 esteiras, uma elétrica e outra manual, 5 prensas, 1 empilhadeira elétrica e outra manual.

- Problemas encontrados:

- Baixo valor dos resíduos enviados à Unidade, já que a coleta seletiva apresenta fragilidade no processo porta-a-porta. Alguns catadores não organizados costumam passar nos domicílios antes do veículo da Comlurb, recolhendo itens de maior valor;

- Como as Cooperativas ainda não conseguiram retirar alguns documentos específicos, não conseguem receber materiais de órgãos públicos ou empresas;

- A possibilidade de operar resíduos de órgãos públicos também apresenta outro complicador: para todos os locais, os resíduos precisam ser coletados no local, gerando um custo logístico para as cooperativas, já que estas não possuem veículo de sua propriedade;

- Alto nível de absenteísmo, já que o valor recebido para operação nesta unidade ainda é muito baixo, gerando pouca atratividade. Além disso, muitos cooperados são dependentes de drogas/álcool;

- As Cooperativas têm muito pouco apoio para programas de gestão, orientação comercial e de produção, gerando baixo aproveitamento dos resíduos. 


\section{APÊNDICE B - Relatório de Pesquisa de Campo - Usina do Caju.}

NOME DO ENTREVISTADO: João Cláudio Jayme França.

CARGO: Sub Gerente da Usina.

DATA DA VISITA : 28/08/2014.

\section{CONTEÚDO ABORDADO:}

Volume de resíduos processados: 3.500 ton/dia.

Tipo do resíduo: Lixo domiciliar, público e coleta seletiva.

Objetivo da Usina: triagem de resíduos para envio à CTR-Rio, reaproveitamento de parte dos resíduos na separação para reciclagem, compostagem e CDR.

Locais de procedência: Centro, Zona Sul e Zona Norte da Cidade do Rio de Janeiro.

Locais para destinação do RSU do município do Rio de Janeiro:

\begin{tabular}{|c|c|c|}
\hline UNIDADE & PESO (ton/dia) & Representatividade \\
\hline ETR Caju & 3.500 & $40,2 \%$ \\
\hline ETR Jacarepaguá & 1.200 & $13,8 \%$ \\
\hline $\begin{array}{c}\text { ETR Marechal } \\
\text { Hermes }\end{array}$ & 1.600 & $18,4 \%$ \\
\hline ETR Santa Cruz & 900 & $10,3 \%$ \\
\hline ETR Bangu & 1.500 & $17,2 \%$ \\
\hline Total RSU & $\mathbf{8 . 7 0 0}$ & $100,0 \%$ \\
\hline
\end{tabular}

Tabela 45 - Locais para destinação dos resíduos no município.

Tempo de operação da Usina: inaugurada em 1992. Fechou as portas em 1995 e voltou a funcionar em 2000.

Descrição do Processo: A Usina do Caju opera com 3.500 toneladas de lixo por dia, sendo que $10 \%$ deste volume recebido é utilizado nos processos para reaproveitamento e $90 \%$ segue para o Aterro Sanitário de Seropédica.

Os processos para reaproveitamento do lixo se dividem em 3, conforme abaixo:

1. Separação para Reciclagem (SPR) - Cooperativa Transformando;

2. Geração de composto;

3. Envio para geração de Combustível Derivado de Resíduos (CDR);

\begin{tabular}{|l|c|}
\hline \multicolumn{1}{|c|}{ PROCESSO } & PROPORÇÃO \\
\hline CDR & $51,7 \%$ \\
\hline COMPOSTAGEM & $36,4 \%$ \\
\hline SPR & $8,7 \%$ \\
\hline REJEITO & $3,2 \%$ \\
\hline TOTAL & $\mathbf{1 0 0} \%$ \\
\hline
\end{tabular}

Tabela 46 - Destinação dos resíduos na Usina do Caju. 
A Tabela 46 informa a proporcionalidade do lixo tratado em cada processo e a quantidade de rejeito gerada.

Considerando que a Usina recebe 3.500 ton/dia, encaminha $10 \%$ deste volume para os processos de reaproveitamento, sendo $8,7 \%$ deste volume resultado do processo de SPR, é possível calcular-se que a Usina gera os mesmos $1 \%$ de itens para a reciclagem, assim como a coleta seletiva.

\section{FLUXO GERAL DO PROCESSO}

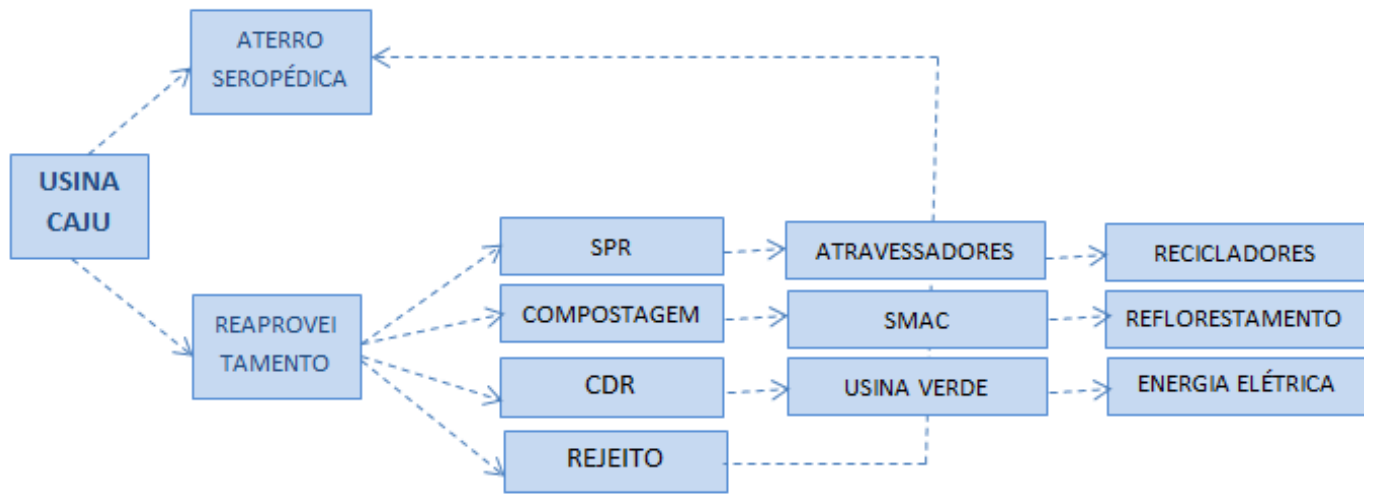

Figura 70 - Fluxo de Operação na Usina do Caju.

a) Separação para Reciclagem (SPR)

Neste processo, a Comlurb conta com razoável estrutura de equipamentos e de pessoas.

A tecnologia dos equipamentos (TRIGA - francesa) foi adquirida na época da inauguração (1992). No início o processo não foi aceito, já que o equipamento não estava adequado aos perfis brasileiros. A Usina foi reaberta em 2001, com adaptações no equipamento, realizadas no Brasil.

Toda a operação é realizada pela Cooperativa Transformando, sob supervisão e gestão da Comlurb, localizada dentro da Usina do Caju, a qual possui 120 cooperados.

A função dos cooperados é separar manualmente os itens recicláveis, prensando-os e comercializando-os para os atravessadores, que coletam os resíduos de sua responsabilidade.

A receita obtida através da comercialização dos resíduos é dividida entre os cooperados de acordo com a produtividade de cada um, medida e controlada pela Comlurb, apresentando lucratividade média mensal: $R \$$ $140.000,00$, gerando aproximadamente $R \$ 1.160,00$ de remuneração mensal aos cooperados. 
A Comlurb direciona os resíduos para este processo de acordo com as rotas dos veículos, originadas de locais com geração de lixo de melhor qualidade (maior quantidade de lixo não orgânico, melhor separado normalmente originado da Zona Sul).

Descrição geral do processo:

\begin{tabular}{|c|c|c|}
\hline ETAPA & $\begin{array}{l}\text { PISO DA } \\
\text { USINA }\end{array}$ & DESCRIÇÃO \\
\hline $\begin{array}{l}\text { PESAGEM DE } \\
\text { ENTRADA DO } \\
\text { VEÍCULO }\end{array}$ & 1ํPISO & $\begin{array}{l}\text { Pesagem inicial do veículo, identificação da } \\
\text { rota de coleta e motorista. }\end{array}$ \\
\hline FOSSO & $1^{\circ} \mathrm{PISO}$ & 2 fossos para armazenagem dos resíduo \\
\hline GARRA COLETORA & 1 PISO & $\begin{array}{l}\text { Garra que busca os resíduos armazenados } \\
\text { no fosso, levando-os ao rasga sacos. }\end{array}$ \\
\hline RASGA SACO & 1\% PISO & Rasga sacos e homogeiniza o lixo. \\
\hline 1ํㅡ CRIVO & 1으요 & $\begin{array}{l}\text { Descarte manual de itens de grande } \\
\text { proporção, que possam vir a travar o } \\
\text { processo (esteira, peneira, outros). }\end{array}$ \\
\hline $\begin{array}{l}\text { ESTEIRA DE } \\
\text { TRANSPORTE }\end{array}$ & TRANSIÇÃO & Esteira mecânica, para transporte do lixo. \\
\hline $\begin{array}{l}\text { ESTEIRA DE } \\
\text { SEPARAÇÃO }\end{array}$ & $2^{\circ} \mathrm{PISO}$ & $\begin{array}{c}\text { Esteira mecânica, para coleta manual dos } \\
\text { itens através dos cooperados. }\end{array}$ \\
\hline ELETROIIMA & $2^{\circ} \mathrm{PISO}$ & $\begin{array}{l}\text { Separação de metais e reenvio de resíduos à } \\
\text { esteira manual. }\end{array}$ \\
\hline TROMMEL & $2^{\circ} \mathrm{PISO}$ & $\begin{array}{c}\text { Separação de itens por tamanho do resíduo } \\
\text { e reenvio à esteira manual. }\end{array}$ \\
\hline $\begin{array}{l}\text { PESAGEM } \\
\text { UNITÁRIA }\end{array}$ & 2요 PISO & $\begin{array}{l}\text { Envio manual de carrinhos à pesagem para } \\
\text { medição de produtividade dos cooperados. }\end{array}$ \\
\hline $\begin{array}{l}\text { DUTO DE } \\
\text { TRANSPORTE }\end{array}$ & TRANSIÇÃO & $\begin{array}{l}\text { Colocação da quantidade pesada na fase } \\
\text { acima em dutos diferenciados por tipo de } \\
\text { resíduo. }\end{array}$ \\
\hline $\begin{array}{l}\text { AGRUPAMENTO DE } \\
\text { RESÍDUOS }\end{array}$ & $1 \stackrel{\mathrm{PISO}}{1}$ & $\begin{array}{l}\text { Armazenagem e acréscimo de valor dos } \\
\text { resíduos (agrupamento por cor, tipo) }\end{array}$ \\
\hline PRENSAGEM & $1 \stackrel{0}{ } \mathrm{PISO}$ & $\begin{array}{l}\text { Prensagem de resíduos, transformando-os } \\
\text { em fardos. }\end{array}$ \\
\hline ARMAZENAGEM & 1으 PISO & $\begin{array}{l}\text { Colocação dos fardos em contêineres } \\
\text { armazenadores de propriedade dos } \\
\text { atravessadores. }\end{array}$ \\
\hline $\begin{array}{c}\text { CONTATO } \\
\text { ATRAVESSADORES }\end{array}$ & 1 PISO & Agendamento para a coleta dos contêineres. \\
\hline $\begin{array}{l}\text { PESAGEM DE SAÍDA } \\
\text { DO VEÍCULO }\end{array}$ & 1요 PISO & $\begin{array}{c}\text { Pesagem para geração do valor de venda a } \\
\text { ser cobrado ao atravessador. }\end{array}$ \\
\hline
\end{tabular}

Tabela 47 - Descrição geral do processo - Usina do Caju.

A maioria dos veículos que chegam à Usina do Caju despejam seus resíduos em um armazém para unificação e novo carregamento aos veículos que se destinam à CTR-Rio. Os veículos para despejo de resíduos no fosso são selecionados no momento da pesagem, quando identifica-se a origem dos locais de coleta e qualidade do lixo. 


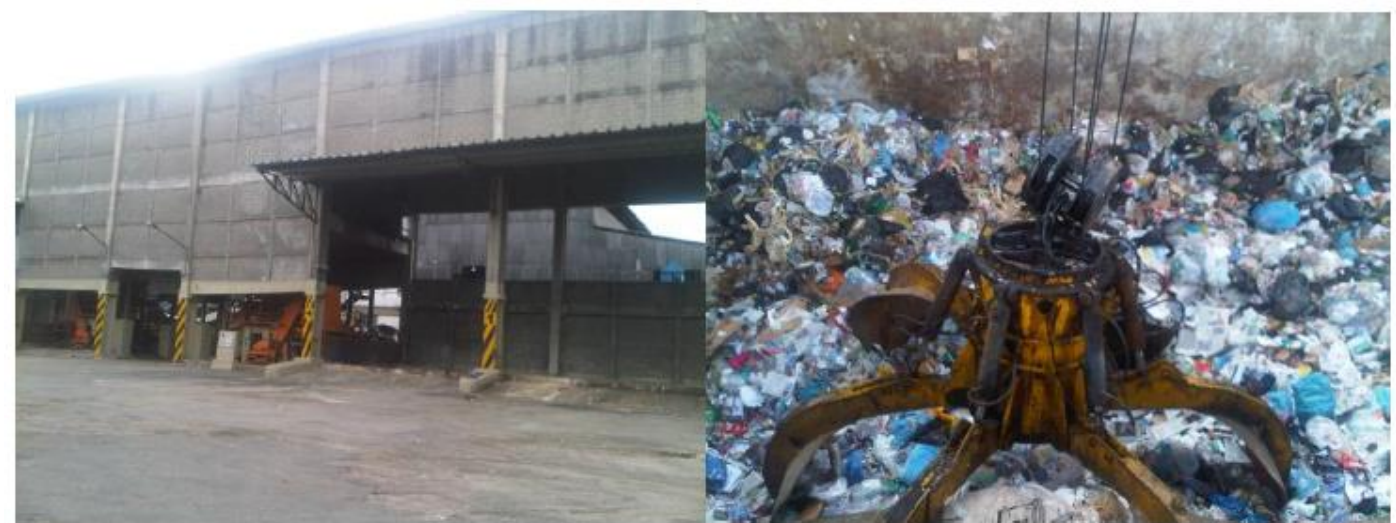

Figura 71 - Foto I - Etapas do processo na Usina do Caju: fachada frontal: entrada dos fossos e garra coletora dentro do fosso.

Após coletados através da garra, são encaminhados ao rasga sacos, descendo pela $1^{\underline{a}}$ esteira, onde localiza-se $01^{\circ}$ crivo, normalmente realizado por 2 cooperados que identificam itens de grandes proporções para retirada destes do processo, visando a redução de entupimentos nas esteiras seguintes.

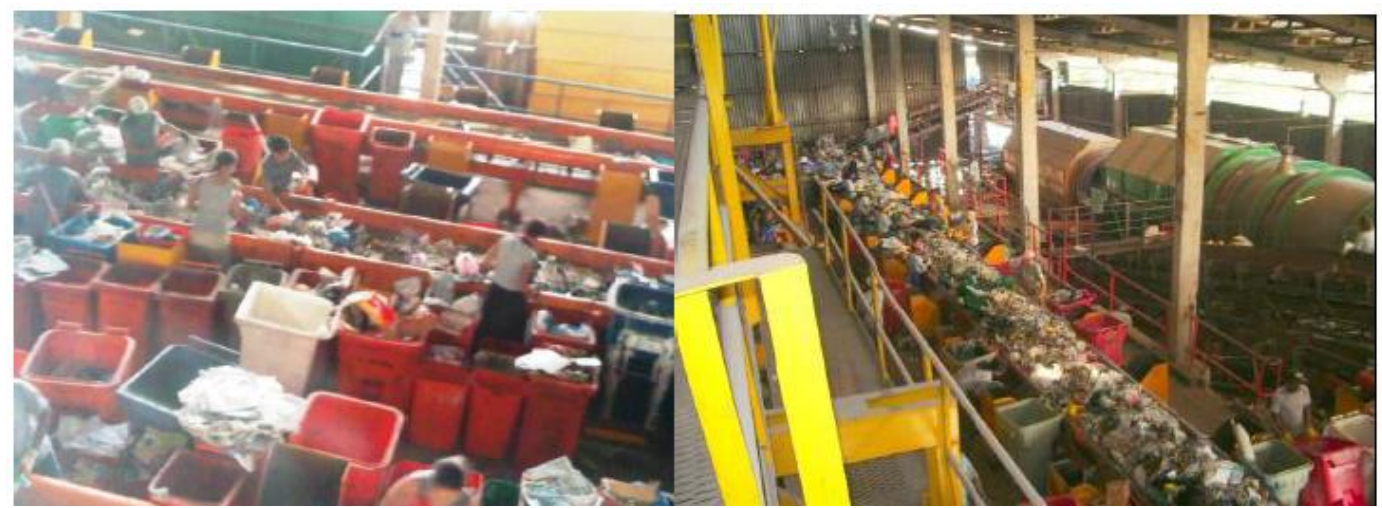

Figura 72 - Foto II - Catação manual na esteira rolante e containers para estoque de materiais recicláveis na Ủsina do Caju.

Estes itens seguem para as esteiras de separação, na qual localiza-se a maioria dos cooperados, grande parte formada por mulheres, que identificam e separam resíduos, colocando-os em lixeiras, conforme figura acima.

Estas são despejadas em dutos específicos para cada tipo de resíduo, caindo em bags de armazenagem no piso inferior. 


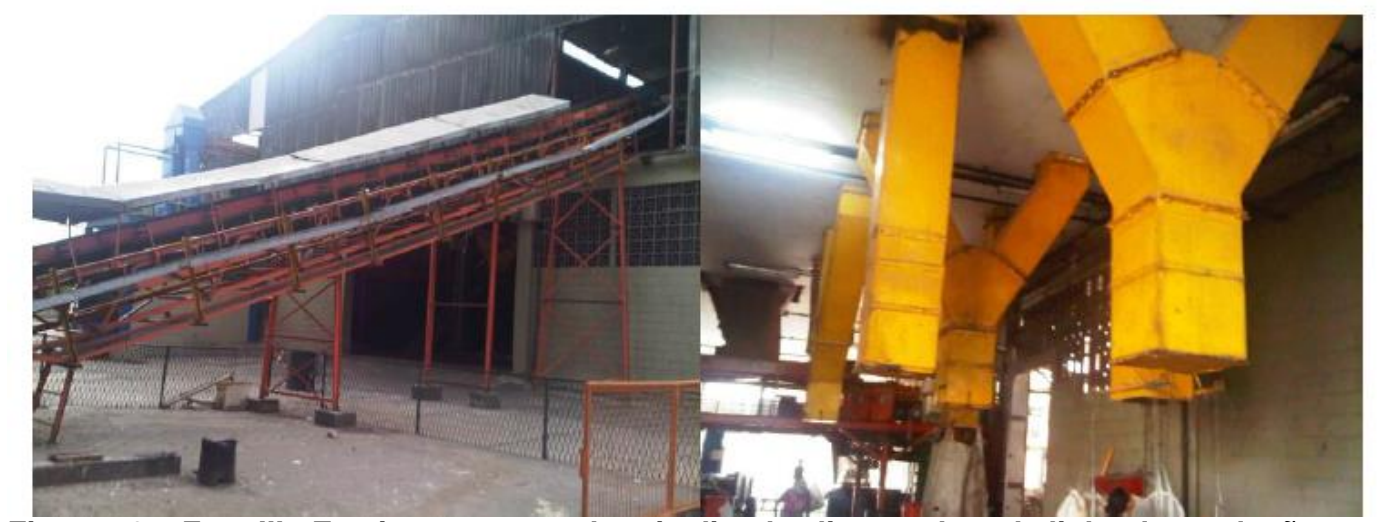

Figura 73 - Foto III - Esteira transportadora inclinada alimentadora da linha de produção e dutos de direcionamento dos resíduos do andar superior para a estocagem na Usina do Caju.

Estes bag's são transportados para os armazéns, onde sofrem nova separação (como exemplo, a diferenciação de cores para o PET), são prensados e armazenados nos containers dos atravessadores, localizados no pátio da Usina.

No mesmo piso das esteiras, localizam-se também um separador magnético e um trommel, também utilizados na separação dos itens recicláveis. Estes também são direcionados para dutos específicos, sendo armazenados em bag's e encaminhados aos containers dos atravessadores.

Uma outra equipe de cooperados é responsável pelo contato com os atravessadores, que acertam o valor de venda, a data de coleta dos containers cheios e entrega dos vazios.

Todos os postos de trabalho são identificados para medição de produtividade e posterior pagamento aos cooperados, após recebimento do pagamento dos atravessadores.

Alguns funcionários da Comlurb acompanham o processo produtivo, orientam e coordenam o processo produtivo.

\section{b) Geração de composto}

Os rejeitos gerados após o processo de SPR (esteiras) são direcionados a uma peneira que separa os itens orgânicos e seguem para um galpão para a criação das leiras. Após 90 dias, são peneirados e processados para a formação do composto.

Este é comercializado principalmente à SMAC (Secretaria Municipal de Meio Ambiente), que utiliza o composto para reflorestamento e contenção de encostas, o maior projeto de replantio nas encostas do Mundo.

Outra parte do composto pode ser comercializado a pessoas físicas, por um valor simbólico ( $\mathrm{R} \$ 32,00 /$ ton$)$. 
Além do volume originado do SPR, a Usina recebe resíduos de algumas empresas, como a Rede Hortifruti.

\section{c) Geração de Combustível Derivado de Resíduos (CDR)}

A fração não utilizada no processo de compostagem (não orgânica) é armazenada e coletada pela Usina Verde, para geração de Energia Elétrica.

A USINAVERDE S/A é uma empresa brasileira de capital privado que tem como objetivo a aplicação de sua tecnologia em conjunto com empreendedores - poder público ou iniciativa privada - interessados na implantação de soluções ambientais, em especial para o tratamento de resíduos sólidos através de Usinas de Recuperação Energética (URE).

A USINAVERDE é pioneira no Brasil, no desenvolvimento de tecnologia para a implantação de Usinas de Recuperação Energética de resíduos sólidos urbanos e industriais, sendo detentora de patentes referentes ao processo de incineração de resíduos sólidos e tratamento de gases de combustão registradas no Brasil e no exterior. Opera desde 2002. (Retirado de http://www.usinaverde.com.br em 28/08/2014).

\section{d) Envio do lixo triado ao Aterro de Seropédica}

Os caminhões não enviados para o fosso descarregam sua carga num galpão de armazenagem ou diretamente numa unidade de transferência às carretas de maior capacidade para envio à Seropédica.

Circulam na rota Caju-> Seropédica 200 carretas/dia.

\section{Ativos/custos}

- Veículos - concessão algumas empresas do ramo Logístico, dentre estas a Julio Simões.

- Equipamentos - propriedade da Comlurb.

- Local - propriedade da Comlurb.

- Manutenção de equipamentos e veículos - responsabilidade da Comlurb.

- Custos fixos (energia, água, demais contas) - responsabilidade da Comlurb. 


\section{APÊNDICE C - Relatório de Pesquisa de Campo - Central Mecanizada Ecourbis}

DATA DA ENTREVISTA: 18/08/2014.

NOME DOS ENTREVISTADOS: ALTAIR SILVA/ PEDRO HENRQUE FARAH

CARGOS: ASSESSORIA DE IMPRENSA DA ECOURBIS/CHEFE DE PRODUÇÃO.

\section{CONTEÚDO:}

- A capacidade desta central é de 250 ton/dia? Tanto para esta unidade quanto para a de Ponte Pequena? A capacidade nominal da Central Mecanizada de Triagem é de 250ton/dia. A unidade ainda não está funcionando a pleno, já que sua inauguração ocorreu em 1 mês.

A capacidade de processamento é maior do que os resíduos coletados atualmente.

Volume processado atualmente: 40 ton/dia, aproveitando $60 \%$ deste volume. Todo o rejeito segue para o aterro sanitário-

A Ecourbis é responsável pela coleta das Zonas Sul e Leste da cidade de São Paulo.

A Loga é responsável pelo restante (Norte, Oeste, Central) - também foi inaugurada em junho uma Central de Tratamento Mecânico de resíduos.

O plano da Prefeitura previa a instalação de 17 galpões para triagem manual. Este projeto foi alterado para 4 Centrais de Triagem Mecanizada, 2 para cada concessionária (Loga e Ecourbis).

Ainda não é possivel processar maior volume, já que somente esta quantidade chega da coleta seletiva (localidades de atuação da Ecourbis).Tal volume de coleta foi restringido exatamente pela falta de capacidade de processamento. Desta forma, há necessidade de revisar o fluxo de veículos da coleta para aumento do volume.

Qual a previsão para esta revisão Logística acontecer e quanto espera-se receber?

Provavelmente há investimento envolvido para a compra de novos veículos, correto? De quem é a responsabilidade da compra? Governo ou Ecourbis?

No início de outubro começaremos a operar com mais dez caminhões compactadores na coleta seletiva. A princípio, não conseguimos mensurar o quanto de acréscimo de material que teremos com esta adesão.

Ecourbis é a responsável pela compra dos equipamentos.

- Estas unidades recebem somente resíduos vindos da coleta seletiva ou da coleta normal?

Somente da coleta seletiva.

De acordo com a Ecourbis, os equipamentos não foram projetados para resíduos originados da coleta normal.

- O valor investido para cada unidade foi de 33 milhões de reais ou este foi o valor total? 
Este foi o valor total, que inclui os equipamentos, como também um prédio. Área total da Central de $4.800 \mathrm{~m}^{2}$.

Este valor foi integralmente pago pela Ecourbis, que será ressarcido pela Prefeitura de São Paulo, de acordo com o contrato de concessão de 20 anos (até 2024).

Não há previsão de cobrança de taxa ao contribuinte. Essa informação é complicada, pois a decisão de criar uma eventual taxa do lixo é da prefeitura, não da concessionária ${ }_{2}$

Equipamentos comprados do Grupo Vauche.

- Todos os equipamentos estão descritos no mapa disponibilizado no site? (16 etapas) Sim. Quadro abaixo.

- É possível saber mais informações sobre estes itens, como gasto de energia, potência e dados do fabricante?

Os dados de gasto de energia estão sendo aferidos. Como a central está em processo de ajustes e calibragens, só conseguiremos passar essas informações posteriormente.

- Como fica a manutenção? Há valor previsto a ser gasto? Somente feita fora do Brasil, já que os equipamentos são importados? Ainda sem valores previstos, pois a unidade foi inaugurada há 2 meses.

- Os catadores que antes trabalhavam na separação maunal foram envolvidos no projeto em sua totalidade? Houve problemas quanto ao possível desligamento dos catadores? São 62 atualmente para processar 250 ton, enquanto normalmente este mesmo número de catadores processaria 60 ton no máximo (dados do Rio de Janeiro).

Em cada turno de sete horas (no início a CMT operará com apenas um) trabalham 42 pessoas. A maior parte são catadores -32 . O restante são mecânicos e operadores de máquinas.

Esses catadores trabalhavam em um central de triagem em um bairro próximo de Santo Amaro.

Além dos 50 catadores, existem também 7 pessoas, funcionários Ecourbis na operação: eletricista, analista, mecânico, 2 ajudantes, 2 operadores do painel de controle.

Principal gargalo do processo: entupimento das linhas, já que recebe-se itens maiores, que não deveriam vir na coleta seletiva, como pedaços de sofá, equipamentos eletrônicos em geral. No início do processo (antes do rasga sacos), é feita uma triagem manual para a retirada destes itens. Esta atividade é realizada por 2 catadores. 


\section{APÊNDICE D - Relatório de Entrevista - Gestão Comlurb}

NOME DO ENTREVISTADO: Hanna Schneider Rodrigues.

CARGO: Assistente I - DAS (Diretoria de Serviços Especiais e Ambientais).

EMPRESA: Comlurb.

DATA DA ENTREVISTA: 18/09/2014. CONTEÚDO ABORDADO:

Como funciona o sistema de coleta seletiva no Município do Rio de Janeiro?

Alguns municípios são atendidos, de acordo com o cadastro através do site da Prefeitura. A Comlurb não disponibilizou a planilha, contendo os bairros atendidos.

Os condomínios/domicílios devem se cadastrar através do site da Comlurb para inclusão no processo.

Além da coleta nos municípios, a cidade conta também com Eco Pontos (PEV's - pontos de entrega voluntária), localizados na Zona Oeste e Comunidades, atualmente em números pouco representativos. A Comlurb trabalhou com mais Eco Pontos, porém sua maioria foi desativada.

Para andamento do processo, a Comlurb aloca 16 veículos de sua propriedade (3 baús, 13 compactadores), arcando com os custos logísticos. Também é responsável pelo envio de resíduos às cooperativas e na manutenção dos equipamentos. A Gestão das Centrais de Reciclagem, destinação dos resíduos do processo e comercialização dos materiais recicláveis é de inteira responsabilidade das cooperativas.

Na coleta seletiva, como é o fluxo atual?

Gerência ADS 1 - atendimento à Zona Sul;

Gerência ADS 2 - atendimento à Barra, Recreio, Taquara, Tanque;

Gerência ADS 3 - atendimento à Tijuca, Méier, Ilha;

Gerência ADS 4 - atendimento à Zona Oeste: Campo Grande, Deodoro;

A Comlurb conta com 16 veículos próprios para este processo e trabalha com algumas cooperativas cadastradas para envio diário dos resíduos.

Não há locais previamente definidos para o envio diário de resíduos coletados neste processo. Diariamente, de acordo com a quantidade de resíduos gerada, define-se o local.

Algumas cooperativas possuem volumes mínimos pré-definidos para destinação diária.

De acordo com a PMGIRS da Cidade do Rio de Janeiro (2013), para atingir a meta de reciclagem $5 \%$ do total de resíduos gerados, 0 sistema de Gestão de Resíduos Domiciliares planeja atuação com 6 Centrais de Triagem, operando com 1.500 catadores, com capacidade produtiva de 30ton/dia por cada Central. Como está a situação atual? 
A meta foi reduzida para $3,5 \%$, devido às dificuldades encontradas para inauguração das Centrais.

Das 6 Centrais de Triagem previstas, a de Irajá está em funcionamento desde janeiro de 2014, processando aproximadamente 20 ton/dia, contanto com 42 catadores.

Além desta, as 5 próximas estão em processo de desenvolvimento, conforme abaixo:

\begin{tabular}{|c|l|}
\hline CENTRAL & \multicolumn{1}{|c|}{ SITUAÇÃO } \\
\hline Bangu & Em finalização de obras. Previsão de inauguração em 2014. \\
\hline Centro & Em finalização de obras. Previsão de inauguração em 2015. \\
\hline Campo Grande & Em liberação de licenças. \\
\hline Jacarepaguá & Em definição de local para operar. \\
\hline Penha & Em definição de local para operar. \\
\hline
\end{tabular}

Tabela 48 - Situação das centrais de triagem previstas para a coleta seletiva do município do Rio de Janeiro.

\section{Estas Centrais processam somente os resíduos domiciliares originados da Coleta Seletiva? Sim.}

E os resíduos provenientes de Órgãos Públicos? De acordo com o contato da Central de Triagem de Irajá, estes resíduos são de melhor qualidade, porém necessitam de aprovação das Cooperativas em editais - necessidade de obtenção de documentação básica (CNPJ) para estar apto a estes.

Sim. Estes também podem ser processados pelas Cooperativas, porém a responsabilidade da coleta é das próprias cooperativas, que muitas vezes não possuem veículo próprio para o serviço de coleta frequente.

Dificuldades encontradas para dar andamento no projeto e cumprimento de metas:

- Pouco material coletado;

- Necessidade de investimento em conscientização ambiental frequente para aumento do volume originado da coleta seletiva;

- Material de maior qualidade originado pelos domicílios muitas vezes é coletado anteriormente pelos catadores autônomos, gerando baixa lucratividade às cooperativas cadastradas;

- A organização das Cooperativas e do processo produtivo é realizada diretamente pelos cooperados, pessoas em sua maioria de baixa escolaridade e pouco conhecimento em gestão e planejamento. Tal questão pode gerar baixa lucratividade no negócio, aumentado as dificuldades para o cumprimento das metas de reciclagem;

- Baixo valor de venda dos resíduos para o mercado de reciclagem venda para atravessadores, já que o volume gerado ainda é baixo para a venda direta;

- O índice de absenteísmo é alto, pois muitos catadores têm problemas sociais, muitas vezes com envolvimento de drogas; 


\section{APÊNDICE E - Orçamento de Equipamentos - Maqbrit}

ORÇ 228 SB/2014

$\grave{A}$

Sra. Jussara Oliveira do Nascimento

PUC-Rio de Janeiro

Cel.: 21 99959-9116

e-mail: jussaon@gmail.com
Santana de Parnaíba, 30 de julho de 2014.

Ref: Usina de Reciclagem de RSD - mod. GTR30/32TDa

Prezada Senhora,

Estamos, no momento, sem tempo de desenvolver os projetos necessários à elaboração do orçamento para a capacidade de $500 \mathrm{t} / \mathrm{d}$. Assim, estamos lhe enviando um orçamento recentemente enviado a um cliente, para capacidade de 300 a $320 \mathrm{t} / \mathrm{d}$. solicite-nos.

Permanecemos à disposição para informações complementares.

Atenciosamente

Claudio Augusto Desideri

\section{I- EQUIPAMENTOS}

2 (dois) Guinchos Hidráulicos, marca MAQBRITTM, mod GH21

Estacionários, completos com base, mastro, lança, caçamba tipo pólipo, motor elétrico blindado trifásico de $20 \mathrm{cv}-6$ pólos, comando hidráulico, bomba, mangueiras, giro $360^{\circ}$ cadeira para operador, passadiço de manutenção em chapa expandida, guarda-corpo e escada de acesso.

2 (dois) Alimentadores de Correia, marca MAQBRIT'TM, mod AC3007/1

Com largura 30" e comprimento 7,1 m, completos com motorredutor elétrico blindado trifásico de $3 \mathrm{cv}-4$ pólos, correia de duas lonas resistente à óleos e graxas, tambores de tração e retorno montados em mancais com rolamentos autocompensadores, roletes-guia, roletes de carga e retorno com rolamentos blindados, selados por labirintos, dupla vedação antipó, assentados em cavaletes de carga e de retorno paralelos, borda bilateral, esticador tipo parafuso, limpador autorregulável, tremonha de carga e estrutura de apoio. 
2 (dois) Alimentadores Mecânicos, rotativos, marca MAQBRIT ${ }^{\mathrm{TM}}$, mod TRDS8523

Desagregador e segregador, com diâmetro de 2,3 e comprimento de $8,5 \mathrm{~m}$, completos com acionamento por motor elétrico blindado trifásico de $15 \mathrm{cv}-4$ pólos, redutor de velocidade, engrenagens, corrente, polias e correias $\mathrm{V}$, cárter de proteção, transmissão por eixo montado em mancais com rolamentos autocompensadores, cruzetas, acoplamentos, flanges, roldanas e pneus, cone de entrada, corpo hexagonal com segmentos perfurados, facas internas, carenagem, chassi, estrutura de apoio, bicas de passantes e retidos, sistema autolimpante externo, passadiço bilateral de manutenção em chapa expandida, guarda-corpo e escada de acesso.

\section{2 (dois) Transportadores de Correia, marca MAQBRIT'TM, mod TC6006/5ps}

Com largura 60" e comprimento $6,5 \mathrm{~m}$, completos com motorredutor elétrico blindado trifásico de $4 \mathrm{cv}-4$ pólos, correia de duas lonas resistente à óleos e graxas, tambores de tração e retorno montados em mancais com rolamentos autocompensadores, roletes-guia, roletes de carga e retorno com rolamentos blindados, selados por labirintos, dupla vedação antipó, assentados em cavaletes de carga e de retorno paralelos, borda bilateral, esticador tipo parafuso, limpador autorregulável, tremonha de carga, calha de descarga e estrutura de apoio.

1 (um) Transportador de Correia, marca MAQBRITTM, mod TC2415mo

Com largura 24" e comprimento $15 \mathrm{~m}$, completo com motorredutor elétrico blindado trifásico de $2 \mathrm{cv}-4$ pólos, correia de duas lonas resistente à óleos e graxas, tambor de tração magnético e de retorno montados em mancais com rolamentos autocompensadores, roletes-guia, roletes de carga e retorno com rolamentos blindados, selados por labirintos, dupla vedação antipó, assentados em cavaletes de carga e de retorno paralelos, cavaletes autoalinhantes, borda bilateral, esticador tipo parafuso, limpador autorregulável, tremonha de carga e estrutura de apoio.

\section{2 (dois) Transportadores de Correia, marca MAQBRITTM, mod TC3625t}

Com largura 36" e comprimento $25 \mathrm{~m}$, completos com motorredutor elétrico blindado trifásico de $4 \mathrm{cv}-4$ pólos, correia de duas lonas resistente à óleos e graxas, tambores de tração e retorno montados em mancais com rolamentos autocompensadores, roletes-guia, roletes de carga e retorno com rolamentos blindados, selados por labirintos, dupla vedação antipó, assentados em cavaletes de carga e de retorno paralelos, cavaletes autoalinhantes, borda bilateral, pistas de deslize em madeira, esticador tipo parafuso, limpador autorregulável, calha de descarga, passadiço bilateral de trabalho e passadiço de circulação em chapa expandida, guarda-corpo, escada de acesso, chutes e estrutura de apoio.

\section{6 (seis) Transportadores de Correia, marca MAQBRIT ${ }^{\mathrm{TM}}$, mod TC3015rc}

Com largura 30" e comprimento $15 \mathrm{~m}$, completos com motorredutor elétrico blindado trifásico de $3 \mathrm{cv}-4$ pólos, correia de duas lonas resistente à óleos e graxas, tambores de tração e retorno montados em mancais com rolamentos autocompensadores, roletes-guia, roletes de carga e retorno com rolamentos blindados, selados por labirintos, dupla vedação antipó, assentados em cavaletes de carga e de retorno paralelos, cavaletes autoalinhantes, borda bilateral, esticador tipo parafuso, limpador autorregulável, tremonha de carga e estrutura de apoio. 
Com largura 16" e comprimento $15 \mathrm{~m}$, completos com motorredutor elétrico blindado trifásico de $2 \mathrm{cv}-4$ pólos, correia de duas lonas resistente à óleos e graxas, tambores de tração e retorno montados em mancais com rolamentos autocompensadores, roletes-guia, roletes de carga e retorno com rolamentos blindados, selados por labirintos, dupla vedação antipó, assentados em cavaletes de carga e de retorno paralelos, cavaletes autoalinhantes, borda bilateral, esticador tipo parafuso, limpador autorregulável, tremonha de carga e estrutura de apoio.

1 (um) Transportador de Correia, marca MAQBRIT'TM, mod TC1612/5fe

Com largura 16" e comprimento $12,5 \mathrm{~m}$, completos com motorredutor elétrico blindado trifásico de $1 \mathrm{cv}-4$ pólos, correia de duas lonas resistente à óleos e graxas, tambores de tração e retorno montados em mancais com rolamentos autocompensadores, roletes-guia, roletes de carga e retorno com rolamentos blindados, selados por labirintos, dupla vedação antipó, assentados em cavaletes de carga e de retorno paralelos, cavaletes autoalinhantes, borda bilateral, esticador tipo parafuso, limpador autorregulável, tremonha de carga e estrutura de apoio.

1 (um) Moinho Triturador, rotativos, marca MAQBRIT'T , mod MTV3020

Para vidro, completos com carcaça bipartida, revestimento interno substituível, eixo rotor montado em mancais com rolamentos autocompensadores, martelos em aço temperado e revenido, bicas de carga e descarga, acionamento por motor elétrico blindado trifásico de $1 \mathrm{cv}-4$ pólos, polias e correias $\mathrm{V}$, e cárter de proteção do movimento.

\section{2 (dois) Imãs Permanentes, marca MAQBRIT TM, mod IP20/30SA}

De limpeza automática, suspensos em olhais e cabos de aço, completos com carcaça de alta permeabilidade magnética protegida contra corrosão, face magnética em aço AISI 304, circuito magnético com imã permanente de ferrite de estrôncio anisotrópico de alta energia, motorredutor blindado trifásico de $1 \mathrm{cv}$ - 4 pólos, correia taliscada, sistema isolante de campo magnético e estrutura de sustentação.

1 (um) Imã Permanente, marca MAQBRIT TM , mod IP20/20SA

De limpeza automática, suspensos em olhais e cabos de aço, completos com carcaça de alta permeabilidade magnética protegida contra corrosão, face magnética em aço AISI 304, circuito magnético com imã permanente de ferrite de estrôncio anisotrópico de alta energia, motorredutor blindado trifásico de $1 \mathrm{cv}$ - 4 pólos, correia taliscada, sistema isolante de campo magnético e estrutura de sustentação.

\section{1 (um) Quadro Elétrico, marca MAQBRIT TM , mod PEC119}

De comando e proteção dos motores, completo com caixa metálica de alojamento estanque, proteção contra particulado, contatores, relés bimetálicos de sobrecarga e falta de fase, fusíveis, régua de bornes, sistema de aterramento e energização por concessionária, indicação por sinaleiros visuais, botoeiras de comando liga/desliga no quadro e à distância, sistema de intertravamento, conduites e enfiação; partida do motor de TRDS e TC-t com inversor de frequência e controle de velocidade.

\section{II-OPCIONAIS}

1 (uma) Cobertura metálica para a unidade de reciclagem, $\sim \underline{1.080 \mathrm{~m}^{2}}$. 
1 (uma) Cobertura metálica para o galpão de prensagem, $\sim 1.050 \mathrm{~m}^{2}$.

\section{III - CONDICÕES GERAIS DE FORNECIMENTO}

Preço posto nossa fábrica em Santana de Parnaíba/SP:

$\mathrm{R} \$ 1.635 .000,00$ (um milhão, seiscentos e trinta e cinco mil reais)

Impostos: inclusos, para empresa com inscrição estadual

Prazo de entrega dos equipamentos: até 180 dias

\section{Escopo de serviços inclusos:}

Anteprojeto civil para instalação dos equipamentos

Montagem eletromecânica, nas seguintes condições:

Maqbrit fornecerá: 1 (um) técnico-montador, livre de passagens, estadia, alimentação e locomoção local;

Compradora fornecerá: 2 (dois) ajudantes braçais, guincho para descarga e assentamento dos equipamentos, equipamentos, ferramentas e insumos necessários.

Testes em vazio e em carga

Manual técnico de operação e manutenção

Garantia: 12 (doze) meses, contados da liberação para embarque, contra defeitos mecânicos de fabricação e montagem, exceto para componentes elétricos; eventual reparo poderá ser feito em nossa fábrica ou no local da instalação, correndo por conta do comprador todas as despesas de guincho e transporte; em nenhuma circunstância poderá ele reclamar por lucros cessantes ou danos emergentes, direta ou indiretamente resultantes da paralisação; em caso de inadimplência, ela será suspensa.

Assistência técnica: permanente; gratuita no período e nas condições de garantia.

Validade da proposta: 10 dias

Equipamentos cadastrados no Finame 